\title{
A DINÂMICA LOCACIONAL DA AVICULTURA E SUINOCULTURA NO CENTRO-OESTE BRASILEIRO
}

\section{LEOPOLDO ViRIATO SABOYA}

\author{
Dissertação apresentada à Escola Superior de \\ Agricultura "Luiz de Queiroz", Universidade de \\ São Paulo, para obtenção do título de Mestre em \\ Ciências, Área de Concentração: Economia \\ Aplicada.
}

PIRACICABA

Estado de São Paulo - Brasil

Julho - 2001 


\section{A DINÂMICA LOCACIONAL DA AVICULTURA E SUINOCULTURA NO CENTRO-OESTE BRASILEIRO}

\section{LEOPOLDO ViRIATO SABOYA}

Engenheiro Agrônomo

Orientador: Prof. Dr. PEDRO VALENTIM MARQUES

Dissertação apresentada à Escola Superior de Agricultura "Luiz de Queiroz", Universidade de São Paulo, para obtenção do título de Mestre em Ciências, Área de Concentração: Economia Aplicada.

PIRACICABA

Estado de São Paulo - Brasil

Julho - 2001 
Dados Internacionais de Catalogação na Publicação (CIP)

DIVISÃO DE BIBLIOTECA E DOCUMENTAÇÃO - Campus "Luiz de Queiroz"/USP

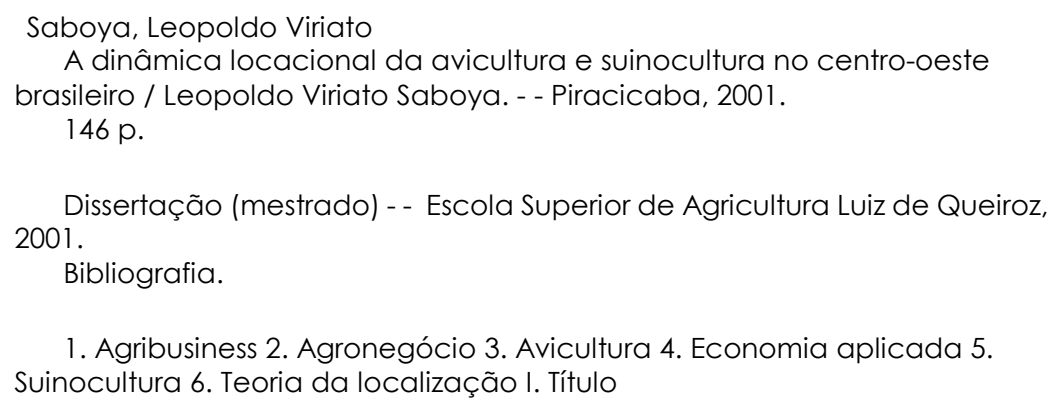

CDD 338.1765

\section{"Permitida a cópia total ou parcial deste documento, desde que citada a fonte - $\mathrm{O}$ autor"}


A minha mãe, Nadyr, formadora do que

carrego de mais valioso comigo: meus

valores de vida, e à Luciana, da qual orgulho

chamar-lhe minha irmã,

dedico esta obra

A minha mulher, Vivian, e a alguém muito especial que ainda está por vir, ofereço 


\section{AGRADECIMENTOS}

Em primeiro lugar, gostaria de agradecer a Deus a oportunidade de nascer numa família católica, que sempre cultivou em mim os verdadeiros valores da vida. Valores, por exemplo, que me ensinaram a estimar o estudo e principalmente àqueles que têm nele sua realização de vida, como o caso do meu amigo-orientador Pedro Marques, professor de entusiasmo ímpar com as conquistas de seus orientados. Fica aqui registrado o meu muito obrigado ao seu total apoio e auxilio na condução da minha pesquisa. Também gostaria de agradecer às valiosas contribuições do professor Caixeta, meu virtual co-orientador. Um muito obrigado vai também a todos os funcionários do Departamento de Economia, Administração e Sociologia da ESALQ, nas pessoas de Cris, Elenice, Helena, Ligiana, Lú, Maiele, Márcia, Pedrão e Valdeci. Amigos foram cultivados ao longo deste precioso período de minha vida. Uns seguem por perto até hoje e assim ficarão. Outros nem tanto. Obrigado Alexandre, Bruno, Fabiano, José, Robson, Ari, Daltro, Paulinho pela amizade demonstrada não somente nos estudos como também nos churrascos e nos jogos de futebol. Daqueles que diretamente contribuíram para a pesquisa de aves e suínos no Centro-Oeste, destacaria as associações de aves e suínos que me receberam muito bem e as empresas respondentes dos questionários, algumas das quais visitei. Fica também o agradecimento pelos dados fornecidos pelo Banco do Brasil, CONAB e Fipe Agrícola e à Bolsa da Capes bem como à ajuda financeira da Fapesp para o projeto. Um carinho especial vai ainda à equipe Trigonet pelo apoio e compreensão quando necessitei ausentar-me da empresa para dedicar-me a este trabalho. Ressalto, por fim, o apoio e total dedicação de três mulheres em minha vida: minha mãe, minha irmã e minha até então namorada, hoje noiva e amanhã mulher, Vivian. A elas, lhes digo: valeu a pena! 


\section{SUMÁRIO}

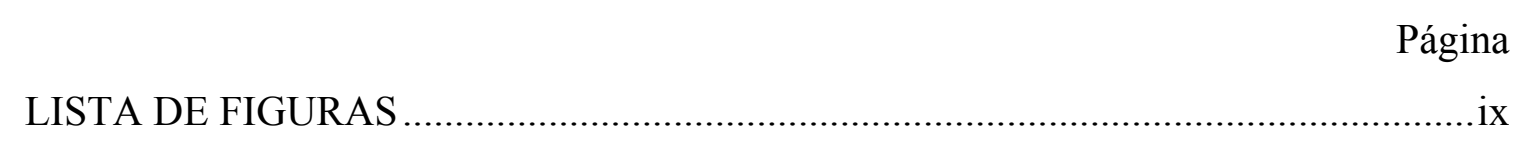

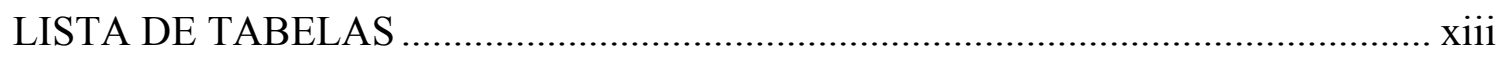

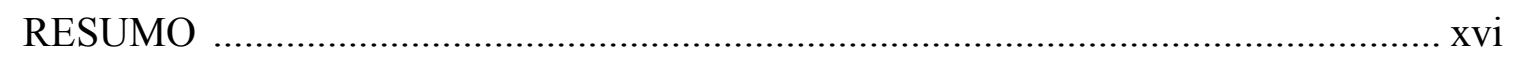

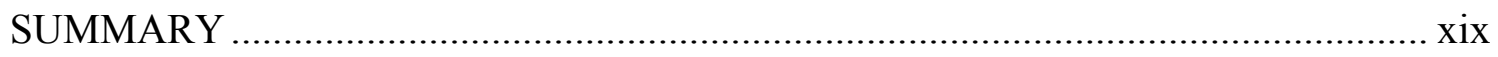

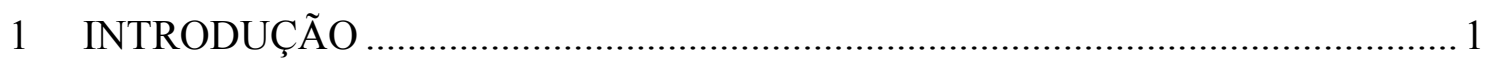

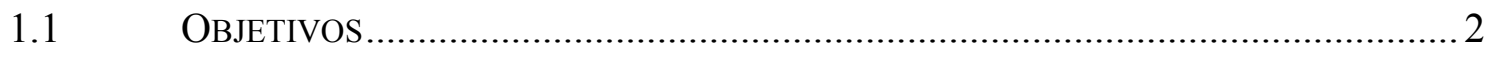

Finalidade e originalidade da pesquisa ................................................... 3

ESTRUTURA DA APRESENTAÇÃ̃ .............................................................. 3

2 REVISÃO DE LITERATURA .................................................................. 4

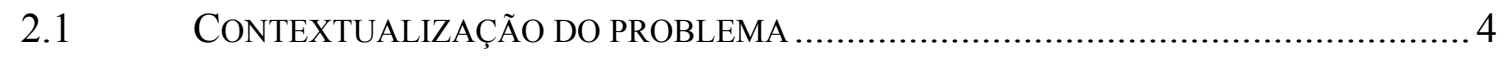

2.1.1 Os cerrados, a agricultura e o agronegócio............................................. 4

2.1.1.1 O agroecossistema dos cerrados ......................................................... 5

2.1.1.2 O processo de ocupação dos cerrados …................................................... 8

2.1.1.2.1 O papel das políticas específicas de desenvolvimento

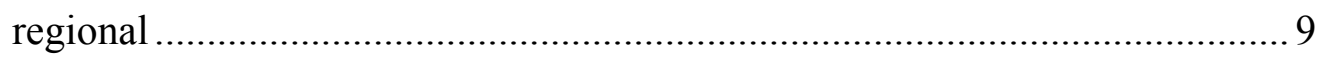


2.1.1.2.2 A evolução da agricultura nos cerrados: soja e milho em

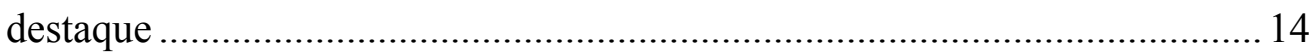

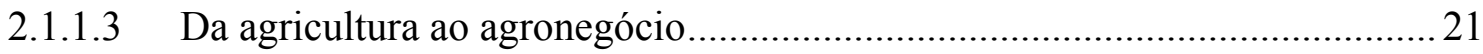

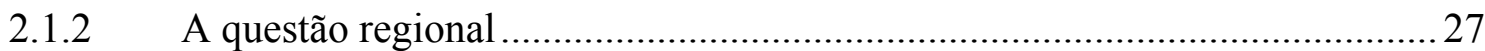

2.1.2.1 Concentração e desconcentração econômica no Brasil nos

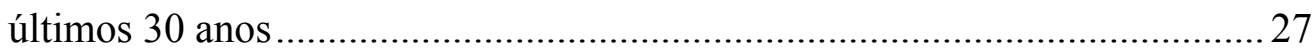

2.1.3 Os vetores locacionais da avicultura e suinocultura ................................... 30

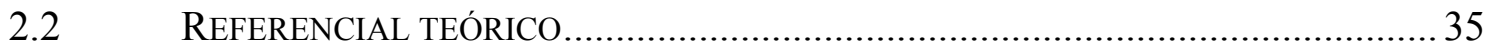

2.2.1 Críticas e considerações sobre os modelos clássicos de

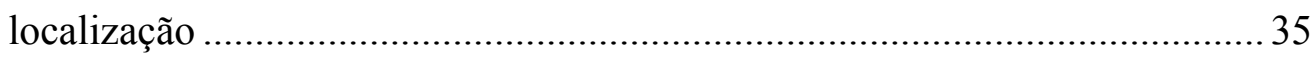

2.2.2 Enfoque comportamental na localização industrial

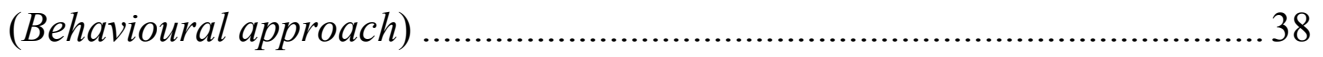

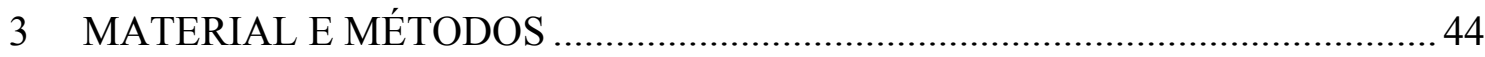

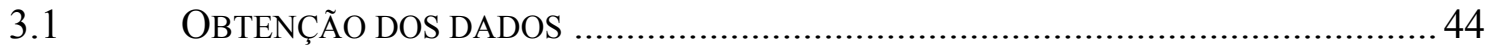

DEFINIÇÃO DAS VARIÁVEIS............................................................. 47

3.2.1 Características dos estabelecimentos.................................................. 47

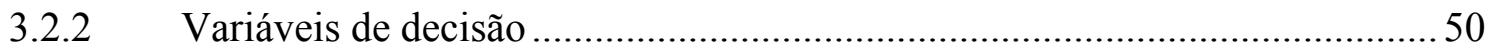

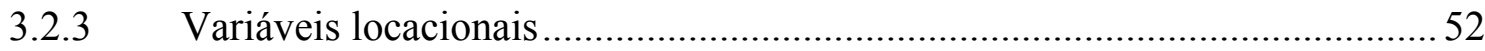

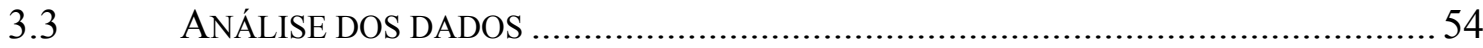

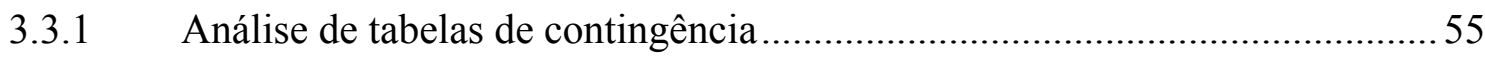

3.3.1.1 Independência e associação entre as variáveis ......................................... 57

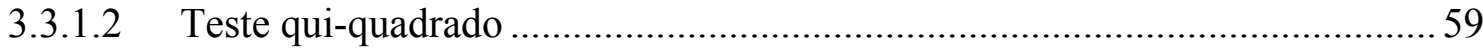

3.3.1.3 Correção de continuidade de Yates e teste exato de Fischer ......................... 60 
3.3.1.4 Exemplo de tabela de contingência e procedimentos do teste qui-quadrado

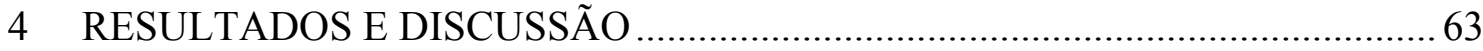

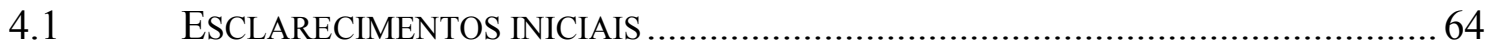

4.1.1 A questão da proporcionalidade universo de empresas

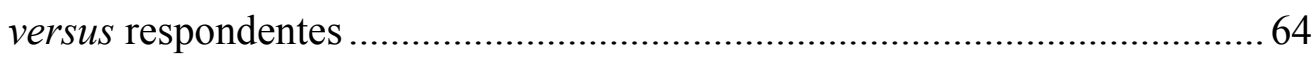

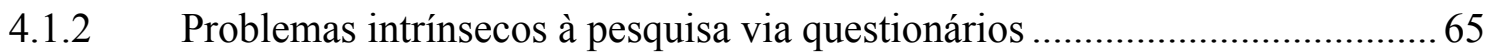

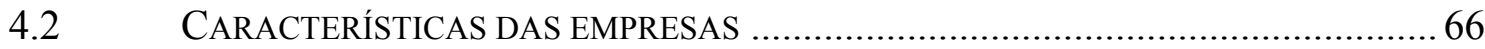

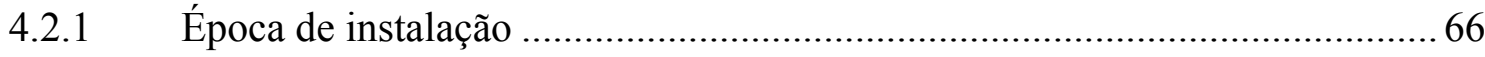

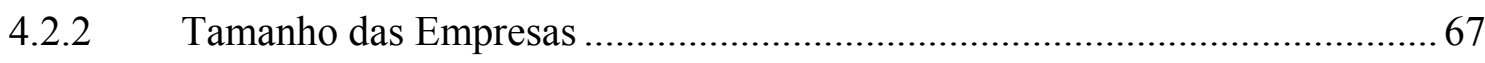

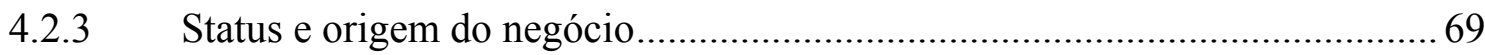

4.2.4 Estrutura produtiva das empresas .................................................... 72

4.2.5 Meta do empresário ...................................................................... 73

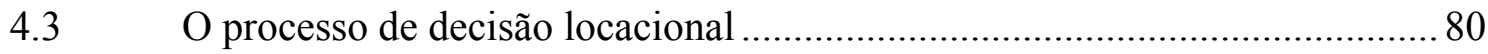

4.3.1 Interpretação das variáveis de decisão.................................................. 81

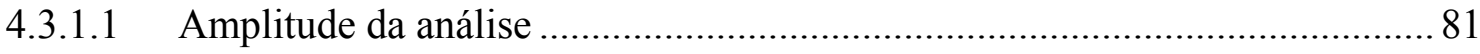

4.3.1.2 Duração do processo de escolha ............................................................ 82

4.3.1.3 Opção pela última alternativa ........................................................... 84

4.3.1.4 Elaboração pela empresa do perfil da localização procurada......................... 86

4.3.1.5 Informações utilizadas na análise do local definitivo................................ 86

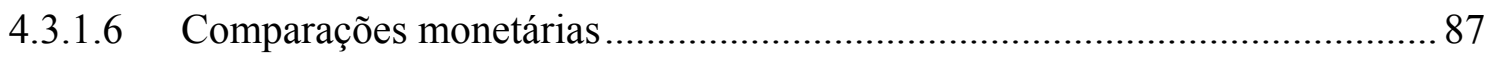

4.3.1.7 Intensidade do estudo da localização................................................... 88

4.3.2 Resultados dos testes de hipótese .................................................... 91 
4.4 Os fatores determinantes da escolha do local ......................................... 94

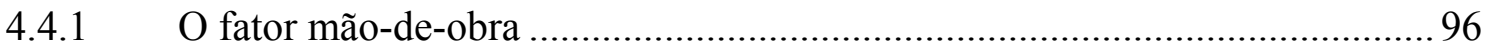

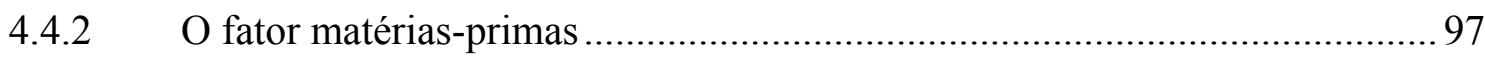

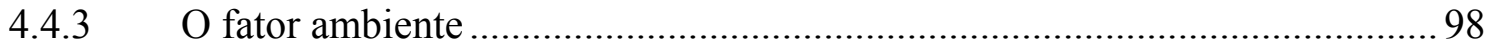

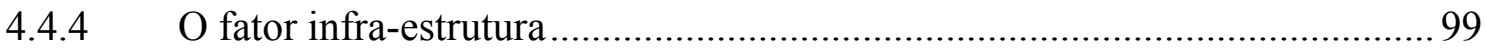

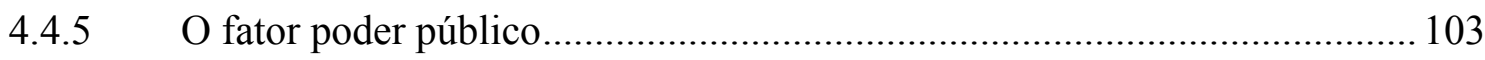

4.4.6 O fator políticas de desenvolvimento regional .................................... 103

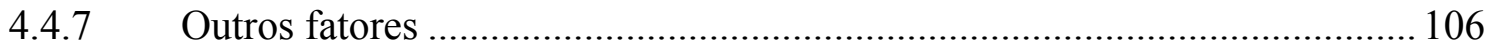

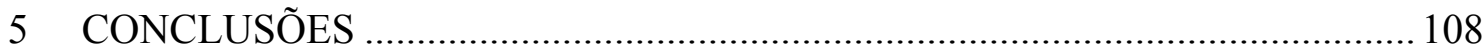

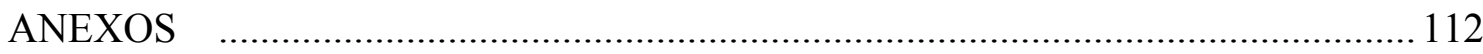

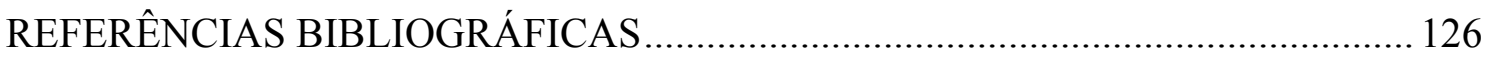

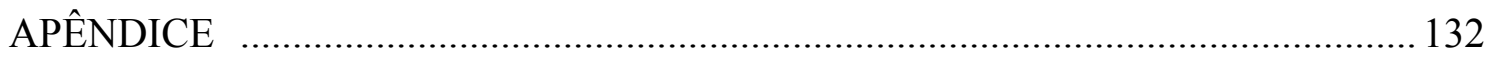




\section{LISTA DE FIGURAS}

Página

1 Abrangência geográfica da área contínua e isolada do cerrado no

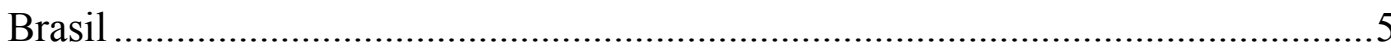

2 Evolução da participação relativa das regiões Norte/Nordeste, Sul, Sudeste e Centro-Oeste na safra brasileira de soja, de 79/80 a $00 / 01$ 16

3 Evolução dos rendimentos ( $\mathrm{t} / \mathrm{ha}$ ) da cultura nacional de soja nas regiões Norte/Nordeste, Sul, Sudeste e Centro-Oeste, de 79/80 a $00 / 01$

4 Evolução da participação relativa das regiões Norte/Nordeste, Sul, Sudeste e Centro-Oeste na safra brasileira de milho, de 79/80 a $00 / 01$. 18

5 Evolução dos rendimentos (t/ha) da cultura nacional de milho na $1^{\mathrm{a}}$ safra, nas regiões Norte/Nordeste, Sul, Sudeste e Centro-Oeste, de $79 / 80$ a $00 / 01$

6 Evolução da participação relativa das regiões Norte/Nordeste, Sul, Sudeste e Centro-Oeste na "safrinha" de milho, de 89/90 a 00/01. 20

7 Matriz comportamental de Pred (modificado de Kellerman, 1989 b, p. 1435) 
8 Classificação das empresas de acordo com a época de instalação do negócios

9 Classificação das empresas por tamanho, usando-se como proxy o número de animais abatidos por dia. 68

10 Classificação das empresas de acordo com o status do negócio 70

11 Classificação das empresas consultadas de acordo com a origem do(s) empresário(s)

12 Classificação das empresas segundo a estrutura produtiva, de acordo com o número de empresas (a) e com a capacidade de abate (b). 73

13 Classificação das empresas consultadas de acordo com a meta do(s) empresário(s) 74

14 Evolução da produção de milho safrinha (segunda safra) por região do país, de 89/00 a 00/01. 75

15 Mapa de localização de todos os abatedouros de aves e suínos considerados na pesquisa dispostos sobre a distribuição espacial da produção média anual de milho na região Centro-Oeste, no período de 95 a 99 76

16 Evolução dos preços médios mensais do milho na praça de Rio Verde-GO 78

17 Evolução dos preços relativos médios mensais do milho cotado em Rio Verde-GO com relação às praças "posto São Paulo" e “Cascavel-PR” de 1996 a 2000 
18 Informações utilizadas pelas empresas na análise do local definitivo

19 Percentual dos itens em que comparações monetárias foram realizadas pelas empresas. 88

20 Importância atribuída pelas empresas a cada fator locacional 95

21 Frequência das notas dadas pelas empresas para qualificar cada item da infra-estrutura 102

22 Montante de recursos concedido pelo Fundo Constitucional de Financiamento do Centro-Oeste para projetos de avicultura e suinocultura, de 1991 a 2000, discriminado por estado 105

23 Número de projetos de avicultura e suinocultura contemplados pelo Fundo Constitucional de Financiamento do Centro-Oeste, de 1991 a 2000, discriminado por estado

24 Gradiente de renda da terra (adaptado de Ferreira, 1989, p.129)

25 Anéis de von Thünen com $n$ culturas (modificado de Ferreira, 1989, p.140)

26 Distribuição espacial das atividades agrícolas (modificado de Ferreira, 1989, p.141).

27 Triângulo locacional (a) e triângulo dos pesos (b) no Modelo de Weber (modificado de Ferreira, 1989, p.82)

28 Triângulo locacional (a) e triângulo dos pesos (b) na determinação no ponto $P$ de custo total mínimo de transporte no modelo de Weber (modificado de Ferreira, 1989, p. 82) 
29 Traçado das curvas isodapanas e determinação da isodapana crítica (modificado de Ferreira, 1989, p.101)

30 Determinação da área de aglomeração no modelo de Weber (modificado de Ferreira, 1989, p. 103)

31 Curva de demanda espacial de mercado (a), cone de demanda (b) e áreas de mercado hexagonais (c) no modelo de Lösch (modificado de Ablas, 1982, p.144,145e148)

32 Triângulo locacional (a) Linha de transformação TJHS e isodespesas (b) (modificado de Azzoni, 1982a, p.114,115) 


\section{LISTA DE TABELAS}

Página

1 Número de estabelecimentos de abatedouros/frigoríficos na região Centro-Oeste, discriminado por estado, tipo de animal e

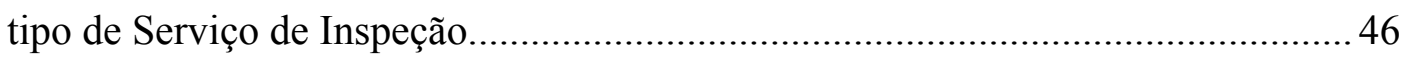

2 Forma geral de uma tabela de contingência de duas dimensões ........................... 56

3 Exemplo de tabela de contingência a ser construída neste estudo ......................... 61

4 Número total de empresas pesquisadas e número questionários respondidos, discriminados por estado, tipo de abate e inspeção ......................... 63

5 Critérios para a classificação do tamanho das empresas...................................... 67

6 Proporcionalidade entre o universo total das empresas e as respondentes, com relação a características selecionadas. Valores em percentuais 65

7 Scores atribuídos a cada item das informações utilizadas (questão 9) bem como das comparações monetárias (questão 10)

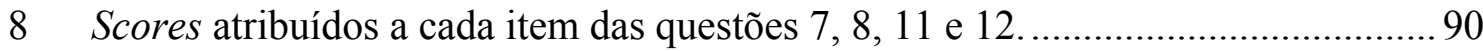

9 Resultado do teste de hipótese para o cruzamento dos pares de características com variáveis de decisão locacional 
10 Evolução da área, rendimento e produção da soja das regiões Norte/Nordeste, Sul, Sudeste e Centro-Oeste, de 79/80 a 00/01

11 Evolução da área, rendimento e produção do milho ( $1^{\mathrm{a}}$ safra $)$ das regiões Norte/Nordeste, Sul, Sudeste e Centro-Oeste, de 79/80 a $00 / 01$

12 Evolução da área, rendimento e produção do milho ( $2^{\mathrm{a}}$ safra $)$ das regiões Norte/Nordeste, Sul, Sudeste e Centro-Oeste, de 88/89 a $00 / 01$

13 Resultados das variáveis característica, cruzadas uma a uma. Dados em valores percentuais, onde as freqüências dos cruzamentos de cada par de categorias foram calculadas na direção das linhas.

14 Resultados dos cruzamentos das variáveis característica com as de decisão locacional (em valores percentuais). (a) freqüências calculadas na direção das colunas; (b) freqüências calculadas na direção das linhas.

15 Resultados dos cruzamentos das variáveis característica com a variável informações utilizadas (em valores percentuais). (a) freqüências calculadas na direção das colunas; (b) freqüências calculadas na direção das linhas 119

16 Resultados dos cruzamentos das variáveis característica com a variável comparações monetárias (em valores percentuais). (a) freqüências calculadas na direção das colunas; (b) freqüências calculadas na direção das linhas 120 
17 Resultados dos cruzamentos das variáveis característica com as respostas grande ou fator decisivo para cada variável locacional

(freqüências calculadas no sentido das linhas). 


\title{
A DINÂMICA LOCACIONAL DA AVICULTURA E SUINOCULTURA NO CENTRO-OESTE BRASILEIRO
}

\author{
Autor: LEOPOLDO VIRIATO SABOYA \\ Orientador: Prof. PEDRO VALENTIM MARQUES
}

\section{RESUMO}

Visando investigar a dinâmica locacional das empresas dos complexos aves e suínos estabelecidas na região Centro-Oeste brasileira, foi conduzida uma pesquisa empírica do processo de decisão locacional e dos fatores-chave na escolha do local produtivo, tendo como referencial teórico uma abordagem comportamental da Teoria da Localização. A pressuposição central deste estudo é a de que os preços mais baixos das matérias-primas básicas (em especial o milho) nos estados da região CentroOeste não são suficientes para explicar o desenvolvimento das atividades dos complexos de aves e suínos nessa região. O método de pesquisa empregado foi o de questionário, enviado para as 46 empresas de aves e suínos presentes no Centro-Oeste no segundo semestre de 2000, contemplando basicamente duas classes de variáveis, as de decisão e as locacionais. Pelo fato de as variáveis terem sido do tipo qualitativas, o instrumental analítico adotado foi a análise de tabelas de contingência, sendo a independência entre os pares de variáveis avaliada através de testes de hipótese. Com taxa de retorno dos questionários de aproximadamente $59 \%$, detectou-se, dentre as principais características 
das empresas, que $74 \%$ instalaram-se na região na década de $90 ; 40 \%$ são empresas grandes, $30 \%$ médias e $30 \%$ pequenas; $64 \%$ das empresas constituíam-se em um novo negócio ou em uma expansão de uma empresa regional, sendo que $45 \%$ das primeiras tiveram empresários oriundos de regiões fora do Centro-Oeste; $83 \%$ da capacidade de abate de aves e suínos está concentrada nas empresas integradoras. Apesar de a estatística descritiva ter sugerido que as empresas grandes, integradoras e oriundas de outras regiões que não o Centro-Oeste tivessem apresentado maior esmero na pesquisa locacional - em termos da abrangência e tempo da pesquisa, das informações e estudos utilizados, da escolha ou não pela última alternativa pesquisada e da elaboração de perfil prévio da localização almejada - os testes de hipótese não significativos acarretaram na não rejeição de independência entre as variáveis. Já a característica meta do empresário, que conseguiu determinar um agrupamento prévio das empresas que as fizesse diferir em seu processo de decisão locacional, em especial entre os grupos de empresas categorizadas com as metas minimizar custos de abastecimento de matérias-primas e apenas iniciar uma atividade produtiva como outra qualquer, apresentou testes significativos. Assim, seja a empresa grande ou integradora, o fato dela ter explicitado não haver uma clara pretensão em estar iniciando, expandindo ou relocalizando sua atividade produtiva no Centro-Oeste, denota a sua pequena preocupação com a localização. Com relação aos fatores locacionais determinantes do local da escolha, foi claro o desequilíbrio entre o elevado nível de importância atribuído ao vetor matériasprimas para com os outros. Os resultados obtidos permitem concluir que o milho de fato age como norteador das atividades de aves e suínos na região Centro-Oeste, configurando-se não somente como fator de atração às empresas, mas também como elemento naturalmente causador de atividades sinérgicas de agregação de valor a jusante da produção. 


\title{
LOCATION DYNAMICS FOR POULTRY AND HOG PRODUCTION IN THE BRAZILIAN MIDWEST
}

\author{
Author: LEOPOLDO VIRIATO SABOYA \\ Adviser: Prof. PEDRO VALENTIM MARQUES
}

\section{SUMMARY}

With a view to research the location dynamics for poultry and hog-raising companies in the Brazilian Midwest, an empiric survey was carried out about the location decision-making, with a behavioral approach to the Localization Theory serving as a theoretical benchmark. The core assumption in this survey is that lower prices for basic input (particularly corn) in the Midwestern states are not enough to explain the development in the poultry and hog complexes in that region. The research method employed was a questionnaire, sent to the 46 poultry and hog companies operating in Midwestern Brazil in the second half of 2000, taking into account, basically, two classes of variables - the ones relating to decision-making and the ones relating to location. Because the variables contemplated are qualitative, the analytical tool set adopted was an analysis of contingency tables, with the interdependence between pairs of variables evaluated through test hypotheses. With an approximate $59 \%$ return on questionnaires sent, it has detected, among other main traits for the corporations, that $74 \%$ of them 
entered the region in the $90 \mathrm{~s} ; 40 \%$ are big, 30\% medium and 30\% small companies; $64 \%$ of them were new businesses or expansions of regional companies, and $45 \%$ of the first group were commanded by businessmen from outside the Midwestern region; 83\% of the slaughtering capacity for poultry and hogs is concentrated on integrators. Although descriptive statistics suggest that big, integrator companies coming from outside Midwestern Brazil have dedicated more effort to location research - in scope and research time; information and studies employed; whether the alternative selected was the last one to be considered; and the previous creation of a profile for the desired location -, the non-significant hypotheses tests denied a dependence between variables. On the other hand, the trait selected as a goal by businessmen, which has resulted in a previous grouping of companies with differences on their location selection process, particularly among companies which had as goals minimizing their raw material costs or only to begin a production activity of whatever kind, has presented significant test results. Thus, albeit the company is big or an integrator, the fact that it has explicitly claimed that it did not intend to begin, expand or relocate activities to Midwestern Brazil shows its lack of care about location. Regarding the location factors that determined a location selection, there was a clear lack of balance between the high importance attributed to the raw material vector and most any other factor. The results obtained allow to conclude that corn is in fact a defining factor for poultry and hog-raising activities in the Midwest, serving not only as an attraction factor for companies but also as en element which naturally brings synergetic value-adding activities as an accessory to production. 


\section{INTRODUÇÃo}

A abertura de fronteiras de produção sempre mereceu atenções especiais de organismos políticos, econômicos e produtivos, desafiados muitas vezes pelo novo, pelo desconhecido. Como característica deste processo, a agricultura apresentou sempre papel pioneiro para o desenvolvimento futuro de atividades afins, não tendo sido diferente para a região Centro-Oeste brasileira.

O processo de avanço tomou impulso a partir de meados da década de 70 , apesar de encontrarmos atividade agrícola de alguma significância em áreas de cerrado já na década de 50. A agropecuária, assim como qualquer outro tipo de atividade primária, logo atraiu e desenvolveu sinergias verticalmente para frente com a indústria de transformação.

A partir da segunda metade da década de 80 , a agricultura crescia juntamente com a atividade agroindustrial e nela vêm se destacando os complexos produtivos de aves e suínos.

Estas duas cadeias produtivas experimentaram transformações tecnológicas, com as técnicas de produção intensiva e desenvolvimento de genética adaptada, transformações organizacionais, com a estrutura de integração coordenada verticalmente por grandes grupos nacionais, internacionais e cooperativas e, mais recentemente, se vêm às portas de sofrer, se não uma transformação, uma mudança na geografia espacial da produção.

O que já foi um dia chamado de o futuro celeiro do Brasil, poderia então ser logo mais rotulado de "frigorífico do Brasil" dado o potencial de desenvolvimento produtivo de carnes, estrategicamente integrado com os crescentes cultivos de cereais. 
Mas é claro que isso seria apenas um exagero. Fato é que grupos líderes atuantes nos complexos grãos-carne estão dirigindo suas atenções e investimentos para a região dos cerrados dentro de uma nova geografia do setor.

Todavia, parece haver um consenso de que os preços mais baixos dos grãos lá produzidos, principalmente os do milho, estariam atraindo investimentos dos complexos avícola e suinícola a partir de uma vantagem comparativa vis-a-vis as principais regiões produtoras no eixo Sul-Sudeste do país.

Entretanto, atribuir à movimentação destas atividades apenas fatores relacionados aos menores custos das rações nestas regiões implicaria em negligenciar toda a dinâmica da decisão locacional por parte de empresas do agronegócio e abster-se de outras forças que atuam na atração de investimentos em regiões de fronteira.

Desta forma, pretende-se aqui estudar o agronegócio do Centro-Oeste brasileiro, objetivando-se conhecer um pouco mais da sua dinâmica. Para isso será desenvolvido um estudo empírico da dinâmica locacional das empresas dos complexos de aves e suínos, contemplando as forças que atuam na atração de investimentos desta natureza.

\subsection{OBJETIVOS}

O objetivo essencial deste trabalho é o de investigar a dinâmica locacional das empresas dos complexos aves e suínos estabelecidas na região CentroOeste brasileira. Para tanto, serão pesquisados empiricamente os processos de decisão locacional, bem como os fatores-chave na escolha do local produtivo. Ter-se-á como referencial teórico uma abordagem comportamental da Teoria da Localização.

Como objetivos tácitos deste estudo, tem-se:

a) maior conhecimento do desenvolvimento de atividades agropecuárias e agroindustriais na região Centro-Oeste; 
b) aplicar o instrumental analítico da Teoria da Localização às atividades do agronegócio, contribuindo, assim, para o desenvolvimento de abordagens adaptadas ao estudo da localização agroindustrial.

\subsection{FinALIDADE E ORIGINALIDADE DA PESQUISA}

Como produto deste estudo, pretende-se conseguir resultados que sinalizem de que forma empresas dos sistemas agroindustriais, sobretudo dos complexos aves e suínos, comportam-se frente a um novo paradigma espacial da produção. Este tipo de informação seria de especial interesse para o poder público conhecer os padrões de localização de estratégicos segmentos produtivos dentro do agribusiness brasileiro.

A Teoria da Localização compreende uma vasta literatura onde aplicações dos modelos clássicos foram feitos, a grande maioria focando a indústria, muitos deles a localização agrícola, e outros poucos as cadeias agroindustriais. Já com relação ao enfoque comportamentalista da Teoria da Localização, não foi encontrada literatura que utilizasse tal abordagem aplicada ao estudo da localização agroindustrial.

\subsection{ESTRUTURA DA APRESENTAÇão}

Este trabalho está organizado da seguinte forma: após este capítulo introdutório, será apresentado um panorama do problema na parte 2 - a revisão de literatura -, apresentando o referencial teórico. No capítulo 3 será detalhada a metodologia empregada neste estudo. No capítulo 4 os resultados e as discussões, e no último capítulo as conclusões. 


\section{REVISÃO DE LITERATURA}

\subsection{CONTEXTUALIZAÇÃo DO PROBLEMA}

O principal intuito deste capítulo é apresentar a problemática de localização do agronegócio em regiões de fronteira, especialmente as atividades de avicultura e suinocultura na região Centro-Oeste. Quer-se assim, evitar tratá-lo de forma fria e unidirecional, onde o problema em questão torna-se apenas um veículo de aplicação de um enfoque e/ou modelo teórico.

\subsubsection{Os cerrados, a agricultura e o agronegócio}

Neste item proceder-se-á a uma descrição do processo de evolução de ocupação da região Centro-Oeste, notadamente do ponto de vista do desenvolvimento das atividades agropecuárias na região a partir da década de 70 e das atividades agroindustriais a partir de meados da década de 80 .

O que se pretende é expor quais foram os condicionantes da expansão da fronteira agrícola, principalmente em regiões de cerrado, de que maneira ela se estabeleceu, para que se possa analisar as bases sob as quais a agroindústria se instalou na região.

Primeiramente será realizada uma breve descrição da região em estudo, evidenciando aspectos da porção denominada de cerrados, por se tratar de um 
ecossistema que particulariza a região Centro-Oeste. Além disso, muitas vezes a divisão política (Centro-Oeste) se confunde com a ambiental (cerrados) e vice-versa. Como será visto, os cerrados vão muito além da região Centro-Oeste, porém é nesta região brasileira onde se concentra o núcleo central e mais dinâmico de tal formação. Ressaltese que a unidade de estudo escolhida neste trabalho é a região Centro-Oeste. Entretanto, como a região será tratada como uma "fronteira da agroindústria", não haverá problema em considerar os cerrados dentro da problemática de localização.

\subsubsection{O agroecossistema dos cerrados}

A região conhecida como cerrado brasileiro localiza-se predominantemente no Planalto Central do Brasil, configurando-se como a segunda maior formação vegetal brasileira, atrás somente da Floresta Amazônica. Este bioma representa $22 \%$ do território nacional, ou cerca de 2 milhões de $\mathrm{km}^{2}$, que abrangem os estados de Mato Grosso, Mato Grosso do Sul, Goiás (cobrindo boa parte da região Centro-Oeste), Rondônia, Tocantins, Maranhão, Piauí, Bahia, Minas Gerais, São Paulo e o Distrito Federal, além de áreas isoladas em outros estados (Figura 1) (WORLD WIDE FUND FOR NATURE - WWF; SOCIEDADE DE PESQUISAS ECOLÓGICAS DO CERRADO - PRO-CER, 1995).

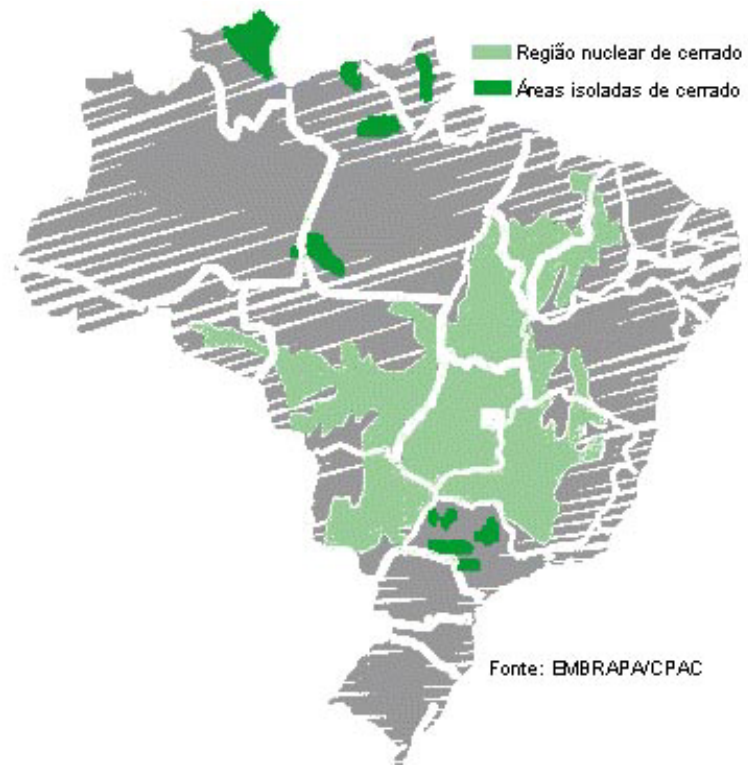

Figura 1 - Abrangência geográfica da área contínua e isolada do cerrado no Brasil 
A designação "cerrado" está associada mais intimamente com as características próprias da vegetação desse bioma, seja através de aspectos florísticos (relativos à flora específica que o distingue de outros biomas brasileiros) ou fisionômicos. Em termos fisionômicos, o cerrado é uma savana tropical de grande diversidade, onde árvores e arbustos coexistem com uma vegetação rasteira formada em sua grande maioria por gramíneas.

Mas não é somente a vegetação que particulariza este ambiente; as características edafoclimáticas sob as quais as diversas expressões da vegetação se desenvolveram (campo limpo, campo sujo, cerrado stricto sensu, e cerradão) sempre denotaram as noções de cerrado um local de clima tropical proeminente e de solos muito pobres do ponto de vista agronômico.

Mais precisamente, o clima do cerrado é do tipo tropical estacional com duas estações bem definidas: chuvosa (de outubro a março) e seca (de abril a setembro), apresentando precipitação média anual de 1500 mm (WWF e PRO-CER, 1995). A temperatura é pouco variável durante o ano, sendo julho o mês mais frio e setembro o mais quente (Cunha et al., 1994).

A imagem que geralmente está associada aos solos da região dos cerrados refere-se a solos localizados em relevo plano ou suave ondulado, bastante intemperizados, profundos e de baixo potencial químico. Como toda generalização acarreta em perdas de especificidades particulares a cada formação, pode-se dizer que mais de $75 \%$ da superfície dos cerrados está coberta com apenas três classes de solos. São eles: Latossolos (representando $46 \%$ do total, são geralmente ácidos, de baixa fertilidade natural e baixa capacidade de retenção de umidade; no entanto são profundos e favorecem a mecanização agrícola; são considerados as maiores reservas para a expansão da agricultura), os Arenoquartzosos (cobrindo 15\% da superfície dos cerrados, são solos pouco desenvolvidos, intemperizados, ácidos e de baixíssima fertilidade; praticamente não apresentam estrutura, retendo pouca umidade), e os Podzólicos (os distróficos cobrem $10 \%$ e os eutróficos cobrem $5 \%$ da superfície dos cerrados; ambos são bem desenvolvidos, profundos e moderadamente profundos, com acentuada diferenciação de textura, cor e estrutura entre camadas, ocorrendo em regiões de relevo 
ondulado a fortemente ondulado; os primeiros são ácidos, de baixa fertilidade natural, com textura relativamente argilosa e boa drenagem interna e os segundos são mais férteis, menos ácidos e contêm maior proporção de argila ${ }^{1}$ (Cunha et al., 1994).

Apesar de haver clareza na definição dos principais condicionantes do agroecossistema do cerrado (vegetação, clima e solos), existe uma grande dificuldade de se definir com exatidão a região de abrangência dos cerrados. Cunha et al. (1994) atribuem a isso a constante transformação da fisionomia da vegetação nativa pela atividade do homem, mais propriamente da agropecuária. Ou seja, uma zona que era cerrado há 30 anos, pode ter deixado de ser considerada como tal.

De acordo com WWF e PRO-CER (1995), apesar de o termo "cerrado" estar sendo utilizado recentemente para designar tecnicamente a vegetação característica que ocorre na região central do Brasil, o conceito vai além da percepção visual. Muito mais que a indicação de um bioma, a simples menção à região dos cerrados nos remete a uma região de fronteira, marginal aos grandes centros urbanos e industriais e que somente a partir dos anos setenta passou a despertar interesse comercial. Até então, se predominava a idéia de que o cerrado não possuía potencial produtivo agropecuário que atendesse aos interesses comerciais, sendo uma região legada à pecuária extensiva e ao extrativismo, em especial ao de madeira para produzir carvão ${ }^{2}$ (Cunha et al., 1994 e WWF e PRO-CER, 1995).

Assim, o conceito de "regiões de cerrado" não é uma menção estática, mas sim dinâmica, que incorpora a noção que o homem faz daquela que é considerada a principal área para a expansão da fronteira agrícola do país (Cunha et al., 1994) e também agroindustrial.

\footnotetext{
${ }^{1}$ Cunha et al. (1994) comentam ainda que o fato destes solos ocorrerem em regiões de encostas não atraiu a agricultura comercial de grande escala. Em virtude de sua maior fertilidade natural, os podzólicos eutróficos foram os primeiros a serem ocupados pela agricultura familiar e acredita-se que toda a área coberta por este tipo de solo já tenha sido ocupada.

2 Tamanha era a convicção de ser impraticável a agricultura nos cerrados que o governo naquela época deu mais ênfase à colonização da Amazônia (Cunha et al. ,1994).
} 
2.1.1.2 O processo de ocupação dos cerrados

De acordo com Cunha et al. (1994), a ocupação dos cerrados teve início há muito tempo. Os primeiros assentamentos na zona que vai de Cuiabá em Mato Grosso ao oeste do atual estado de Goiás remontam o século XVIII. As descobertas de ouro e outras pedras preciosas atraíram expedições em eventos desconexos. Logo a economia da região regrediu a uma agricultura de subsistência e a uma pecuária extensiva quando as modestas reservas exauriram-se. Com isso, os contatos desta remota região com o restante do país e exterior escassearam-se.

Somente em 1930, após a construção da ferrovia ligando São Paulo a Anápolis no centro do atual estado de Goiás, é que regiões do Triângulo Mineiro e sul de Goiás tiveram um assentamento mais intensivo (id. ibid.).

Cunha et al. (1994) afirmam que foi justamente por essa região que se iniciou o chamado avanço da fronteira agrícola nos cerrados. Evidentemente que a maior proximidade aos mercados do centro-sul do país ajudou a consolidar a região como tal.

Todavia, a expansão somente ganhou ímpeto com a construção da cidade de Brasília na década de 50. O deslocamento da Capital Federal para o centro do país obrigou a construção de malha viária ligando-a ao núcleo dinâmico do país (WWF e PRO-CER, 1995).

De fato, a construção de Brasília foi um marco no desenvolvimento dos cerrados. Não só as atenções se voltaram para o centro do Brasil: investimentos em infra-estrutura possibilitaram e atraíram, preferencialmente ao longo da malha viária que ligava o Centro-Oeste às demais regiões, a agricultura (Cunha et al., 1994 e Macedo, 1995).

No entanto, apenas em fins da década de 50, conforme discute Mueller (1990), começou a ocorrer o avanço propriamente dito das frentes de agricultura 
comercial $^{3}$ pelo Centro-Oeste. $\mathrm{O}$ autor também ressalta que na década de 60 completouse a ocupação de terras aptas para o cultivo com as técnicas agropecuárias até então conhecidas. Assim, áreas mais setentrionais do Centro-Oeste, onde predominam os cerrados, arrefeceram o movimento de frentes comerciais pela ignorância quanto ao cultivo.

Maior enfoque sobre a colonização dos cerrados deu-se no início da década de 70, quando foram criados programas especiais de estímulo à agricultura nessas regiões (id. ibid.). Por sua vez, o crescimento da demanda de produtos agrícolas na porção mais dinâmica da economia brasileira reafirmou a necessidade de uma canalização de esforços para o fomento dos cerrados, materializados principalmente através de políticas de desenvolvimento regional, sob a influência também de políticas agrícolas gerais, detalhadas no próximo item.

"No entanto, impacto limitado teriam tido esses fatores se não fosse o desenvolvimento científico e tecnológico que se verificou a partir de 1970. Antes dele, a agricultura cingia-se a manchas de solos férteis dentro da região dos cerrados. Os cerrados propriamente ditos foram uma conquista da pesquisa agronômica desenvolvida no país" (Cunha et al., 1994, p. 48).

\subsection{O papel das políticas específicas de desenvolvimento regional}

As estratégias e políticas de desenvolvimento aliadas a investimentos públicos em infra-estrutura básica, particularmente no período de rápido crescimento da atividade agropecuária nos cerrados, entre 1968 e 1980, tiveram consideráveis impactos sobre a expansão agrícola e ocupação dos cerrados (Cunha et al., 1994 e WWF e PROCER, 1995).

No entanto, até o fim da década de 60, o envolvimento do Estado na evolução da fronteira agrícola manteve-se tímido, inexistindo programas especiais para

\footnotetext{
${ }^{3} \mathrm{O}$ autor identifica em seu trabalho 4 tipos de frentes na expansão da fronteira agropecuária no CentroOeste: (a) frentes de agricultura comercial (viabilizadas por disponibilidade de terras com bom potencial e políticas públicas concretas); (b) frentes de subsistência ou camponesa (ocupação de terras disponíveis por migrantes do Centro-Sul); (c) frentes especulativas (tiveram como impulsionadores os programas governamentais para colonização da Amazônia, caracterizadas por empreendimentos agropecuários extensos, de caráter meramente especulativo); e (d) frente de pecuária extensiva rudimentar.
} 
fomentar a expansão agropecuária do Centro-Oeste. Segundo Mueller (1990), a expansão das frentes de atividade, até então, foi basicamente espontânea. Já na abertura durante a fase de franca expansão, "o envolvimento do Estado não só foi mais intenso, como teve papel fundamental na orientação - e na geração de consideráveis distorções do processo de abertura e ocupação da região" (id. ibid., p. 50)

Esse envolvimento mais intenso do Estado deu-se através da condução de políticas de desenvolvimento regional, com diretrizes nem sempre determináveis, efetivadas principalmente sob o modelo de programas de desenvolvimento. Influência tiveram também as políticas agrícolas gerais e programas de investimento em infraestrutura (Mueller, 1990).

Dentre os vários programas conduzidos no passado para estímulo e manutenção da expansão agropecuária em áreas de cerrado, merecem destaque o Polocentro e o Prodecer.

Antes mesmo da efetivação destes programas, o crédito subsidiado, que vigorou do início dos anos 70 até por volta de 1983, funcionou como a "pedra angular da política agrícola" (Cunha et al., 1994, p. 52), responsável pelo vigoroso crescimento da agricultura dos cerrados.

A conjugação de recursos financeiros em volume apreciável, prazos compatíveis com o período de maturação dos projetos de investimento e juros altamente subsidiados, proporcionaram a empreendedores agrícolas um ambiente favorável à captação de recursos e financiamento de seus projetos. A crítica caiu exatamente em relação às distorções distributivas (favorecia maiores proprietários de regiões mais prósperas) e alocativas (remunerava mais à propriedade da terra e à especulação que à produção ${ }^{4}$ ) do crédito (Cunha et al., 1994).

Como precursor do Polocentro, Mueller (1990) destaca que em 1972 foi criado o Programa de Crédito Integrado (PCI) pelo Banco de Desenvolvimento de Minas Gerais (BDMG) com o objetivo básico de estimular a expansão de agricultura

\footnotetext{
${ }^{4}$ Dentre as consequências desta distorção, somada à aceleração inflacionária, a terra passou a ser reserva de valor. $\mathrm{O}$ aumento da demanda por terras e a política de crédito rural elevaram o seu preço.
} 
empresarial tecnificada em regiões de cerrado do estado. O PCI funcionou como projeto -piloto para um programa de maior abrangência que ficou conhecido como Programa de Desenvolvimento dos Cerrados (Polocentro).

Criado em 1975, o Polocentro foi sem dúvida o principal programa de expansão sobre regiões de cerrado (Macedo, 1995 e WWF e PRO-CER, 1995), apesar de muitas vezes ter seus objetivos distorcidos.

Alicerçado sobre o fornecimento de linhas de crédito favorecidas e extremamente atrativas ${ }^{5}$, o programa beneficiou principalmente produtores de médio a grande porte (Cunha et al., 1994 e Mueller, 1990). A pequena agricultura da região praticamente não se beneficiou. Setores influentes conseguiram atrair a administração a seu favor, desvirtuando os objetivos presentes nos documentos básicos da criação do programa (Mueller, 1990).

Mesmo assim, vale a pena destacar alguns de seus resultados. Dos 3 milhões de hectares que o programa pretendeu incorporar (essa marca não foi alcançada), 60\% seriam de lavouras e 40\% voltados à pecuária. Para a área do Polocentro como um todo, a meta original se inverteu (Cunha et al., 1994 e Mueller, 1990).

Durante o período de vigência do programa ${ }^{6}$, há que se enaltecer a prosperidade da soja em regiões de cerrado. Para se ter uma idéia, Mueller (1990) mostra que a área colhida da leguminosa passou de 81.719 ha em 1975 para 519.579 ha em 1980, enquanto que a área cultivada com milho cresceu pouco, não apresentando o mesmo desempenho da soja.

A soja foi realmente a cultura que desbravou o Centro-Oeste, mesmo sendo a cultura do arroz responsável na época em "amansar a terra" para posteriormente implementar outros cultivos de maior rendimento como a soja. Assim, o crescimento absoluto que a cultura do arroz presenciou na região durante a década de 70, esvaiu-se

\footnotetext{
5 Principalmente pelo caráter amplo das linhas de crédito que contemplavam vários segmentos: o fundiário, o de investimentos e o de custeio (Cunha et. al., 1994).

${ }^{6}$ Apesar de virtualmente o programa ter cessado de liberar créditos em 1982 (concomitantemente com a drástica redução do crédito rural subsidiado a partir de 1983), os seus efeitos ultrapassaram o ano de 1984 devido ao período de maturação de vários projetos de investimento.
} 
nas décadas seguintes quando a tecnologia já desenvolvia novos manejos sem a necessidade de arranque inicial com o arroz.

E não foi apenas a agricultura como um todo que cresceu na região dos cerrados. Além do apoio direto ao agricultor, o programa previa investimentos em infraestrutura básica. Foi através da transferência de recursos do Polocentro à EMBRAPA que foi criado o Centro de Pesquisa Agropecuária dos Cerrados (CPAC) (Cunha et al. 1994 e Macedo, 1995). O incentivo à pesquisa agronômica para a geração de tecnologia adequada às condições edafoclimáticas peculiares à região dos cerrados beneficiou sobremaneira a solidificação e o crescimento das principais culturas neste ambiente ${ }^{7}$.

O outro programa de relevância, o Programa de Cooperação NipoBrasileira para Desenvolvimento dos Cerrados (Prodecer), deu considerável impulso à agricultura dos cerrados do noroeste de Minas Gerais e oeste da Bahia (Cunha et al., 1994). A idéia básica do programa era a de promover o assentamento de colonos do Sul e Sudeste, selecionados por cooperativas credenciadas. As fazendas seriam de médio porte (entre 250 e 500 ha), dedicadas primordialmente à produção de grãos (Mueller, 1990).

O principal instrumento financeiro do Prodecer foi $\mathrm{o}$ crédito supervisionado (com taxa de juros reais), administrado por organização de direito privado, dirigida conjuntamente por executivos brasileiros e japoneses (Cunha et al., 1994; Mueller, 1990 e WWF e PRO-CER, 1995).

Ainda que pouco abrangente em comparação ao Polocentro ${ }^{8}$, o Prodecer, por ser muito bem estruturado, atraiu empreendedores de sucesso e talvez o seu efeito multiplicador tenha ido além dos projetos estabelecidos sob seu cunho.

\footnotetext{
${ }^{7}$ WWF e Pro-cer (1995) comentam que, não obstante os resultados positivos em produção e produtividade nos cerrados, as tecnologias dirigiam mais propriamente aos médios e grandes produtores, cujo maior nível de educação e cultura facilitou-lhes ainda mais o acesso ao crédito subsididado, focando seus esforços para o plantio de culturas mais rentáveis, como é o caso da soja.

${ }^{8}$ De acordo com Mueller (1990), até 1990 o programa teria incorporado à agricultura 200 mil hectares (600 produtores).
} 
Das políticas agrícolas que mais fortemente influenciaram o desenvolvimento da agricultura nos cerrados após meados da década de 80 (ou após o Polocentro), merece destaque a Política de Preços Mínimos.

Cunha et al. (1994) comentam que até 1984, os preços mínimos significaram muito pouco para a política de preços agrícolas, pois eram fixados, em geral, abaixo dos preços de mercado. Apenas funcionou esporadicamente associada a crises de abastecimento.

Somente a partir de 1985, em virtude de fortes críticas do Fundo Monetário Internacional (FMI), Banco Mundial e setores da sociedade dirigidas ao crédito subsidiado, "os preços mínimos tomaram-lhe o lugar como principal instrumento de política agrícola" (id. ibid, p. 60).

O governo federal passou então a adquirir volumes consideráveis da produção nacional - principalmente soja, arroz e milho - por meio desta política. Como os preços eram unificados para todos os estados da federação ${ }^{9}$, regiões distantes dos grandes centros consumidores, onde o elevado custo de transporte reduziria substancialmente o preço líquido ao produtor, como o caso dos cerrados, foram beneficiadas. Atualmente os preços mínimos não são mais unificados, onde o Governo Federal determina para cada ano agrícola, através dos Planos Safras, os preços individualizados para cada região.

Enfim, não somente o desaparecimento do Polocentro no início dos anos 80 como também os sucessivos insucessos da expansão da fronteira agrícola/produtiva para a Amazônia ilustram como "a situação econômica global, inicialmente desfavorável, com a recessão econômica, os juros estratosféricos e o desaparecimento dos investimentos públicos" (Cunha et al., 1994, p. 61) inverteu o clima de empolgação do início da expansão da fronteira agrícola para os cerrados.

\footnotetext{
9 Segundo Cunha et al. (1994), presumivelmente calculados tendo como base regiões de custos mais elevados.
} 
2.1.1.2.2 A evolução da agricultura nos cerrados: soja e milho em destaque

A paisagem da região dos cerrados, principalmente àquela contida dentro do Centro-Oeste brasileiro, sofreu uma profunda alteração nos últimos 30 anos. Savanas foram substituídas por imensos campos de lavoura e por gramíneas exóticas para a formação de pastagem. A região passou a chamar a atenção da pesquisa, da sociedade como um todo e de empreendedores que viam na imensidão dos cerrados, a prosperidade.

Apesar de todos os contratempos políticos e econômicos e das várias distorções que os programas de desenvolvimento regional dos cerrados legaram à atividade agropecuária, é fato que a região Centro-Oeste evolui de uma zona de fronteira agrícola para um importante pólo produtor de, principalmente, grãos.

Dos 207 milhões de hectares ocupados pelos cerrados no território nacional (Macedo, 1995), 47 milhões foram incorporados à produção agropecuária, sendo 35 milhões de hectares relativos a pastagens plantadas e 10 milhões de hectares com culturas temporárias (Arantes, 1998).

Para se ter uma idéia do rápido crescimento da agricultura na região dos cerrados, Cunha et al. (1994) indicam que, entre 1970 e 1985 aumentou em 5,4 milhões de hectares (de 4,1 para 9,5 milhões) a área cultivada, principalmente com soja, milho, arroz, feijão, café e mandioca.

Estima-se ainda, de acordo com Arantes (1998), que 90 milhões de hectares estariam aptos a produzir grãos, de um total de 150 milhões de hectares a serem explorados. Macedo (1995) avalia que, levando-se em conta a restrição que a legislação prevê (manutenção de $80 \%$ das terras como reserva) e o potencial do uso das diferentes classes de solo (segundo a EMBRAPA), 136 milhões de hectares poderiam ser incorporados ao processo produtivo como um todo.

O otimismo revelado através de várias perspectivas para o futuro agrícola da região dos cerrados, ilustra bem o que representa o potencial dos cerrados à comunidade científica. Para Arantes (1998, p. 23), o Centro-Oeste "se notabiliza por ser uma das últimas regiões contínuas para a expansão da produção agrícola do mundo”. Macedo (1995), traçando um cenário alternativo das áreas atualmente ocupadas através 
de uma reestruturação na área destinada a grãos-sequeiro, grãos-irrigado e pecuária e, utilizando-se tecnologia disponível, seria possível a realização de uma produção de quase 100 milhões de toneladas (t), classificou os cerrados como "a alternativa para a produção de alimentos no limiar do século XXI” (id. ibid., p. 11).

Independentemente das propostas e expectativas para os cerrados, vale destacar o que de fato ocorreu com agricultura da região, notadamente as culturas da soja e do milho, que além de figurarem atualmente como as duas mais produzidas, são particularmente importantes para a avicultura e suinocultura.

Conforme já salientado no item anterior, a cultura da soja foi o grande destaque durante a vigência do Programa de Desenvolvimento dos Cerrados (Polocentro). Além deste fato, a estrutura fundiária altamente concentradora, com grandes fazendas nas mãos de uma minoria de produtores, possibilitou à soja surgir grande nos cerrados.

O dinamismo desta cultura nos cerrados, observado após a metade da década de 80, ancorado num crescente aumento da demanda mundial pelo grão, deveuse não somente à abertura de uma "nova" fronteira de produção agrícola. WWF e PROCER (1995) destacam ainda dois outros fatores que foram fundamentais para o crescimento da soja nos cerrados: os preços favoráveis existentes por alguns anos, atrelados às políticas de incentivos à agricultura de fronteira (notadamente a de preços mínimos unificados) e, a evolução de tecnologia adaptada às condições de cerrado. Em 1990, a área nos cerrados destinada à soja já correspondia a cerca de $1 / 4$ da área nacional destinada à cultura (Cunha et al., 1994).

De acordo com Cunha et al. (1994), a tendência de crescimento acelerado presenciado na década de 80 para a cultura da soja nos cerrados reverteu-se após 1990 . Atribuem a este fato, a redução da disponibilidade de crédito e a tentativa de introdução de preços mínimos regionalizados no governo Collor.

A Tabela 10 no Anexo A, que traz o desempenho da soja nas diferentes regiões do Brasil (em termos de área, rendimento e produção), ilustra a redução que a 
lavoura sofreu na virada da década de 80 para a década de $90^{10}$. Esta perda de área e, consequentemente produção, somente foi recuperada na safra 92/93.

Na safra mais atual à realização deste trabalho, 99/00, segundo dados da Companhia Nacional de Abastecimento (CONAB), a produção de soja do Centro-Oeste equivale a $46,2 \%$ da safra nacional, ultrapassando a região Sul, historicamente a principal região produtora do país. Na Figura 2 observa-se o constante ganho de participação relativa na safra nacional de soja da região Centro-Oeste vis-a-vis a região Sul.

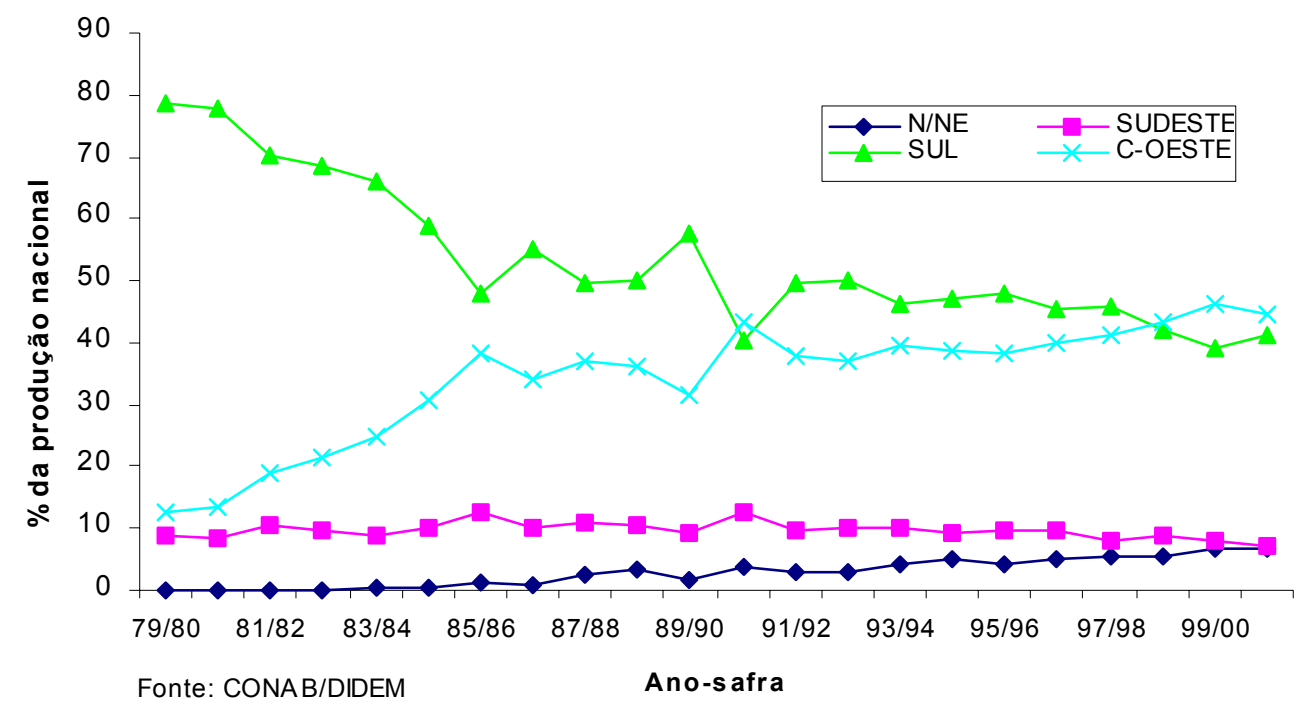

Figura 2 - Evolução da participação relativa das regiões Norte/Nordeste, Sul, Sudeste e Centro-Oeste na safra brasileira de soja, de 79/80 a 00/01

Mafioletti (2000) ressalta em seu trabalho que desde o final da década de 70 a soja avançou nas regiões de cerrado graças ao desenvolvimento de técnicas de adubação e calagem adotadas para solucionar a alta acidez e baixa fertilidade natural dos solos da região. Além disso, o trabalho da EMBRAPA foi decisivo para o desenvolvimento de variedades adaptadas à região. $\mathrm{O}$ autor (id. ibid.) ainda destaca outros fatores que garantiram à cultura da soja ter este grande crescimento no Centro-

\footnotetext{
10 Destaca-se que, apesar dos dados referirem-se à região Centro-Oeste e não aos cerrados, não se desmerece a análise de caráter puramente ilustrativo. Ademais, o principal núcleo agrícola dos cerrados está sob a região Centro-Oeste do Brasil.
} 
Oeste e acabar superando a participação da região Sul na oferta nacional como a instalação de plantas de esmagamento de soja, desenvolvimento de infra-estrutura e, recentemente, as novas alternativas de escoamento da safra através dos rios Madeira e Amazonas.

Com relação aos níveis de rendimento encontrados nas sucessivas safras nacionais de soja, observa-se na Figura 3 uma relativa homogeneidade, principalmente na década de 90, entre as regiões. Este comportamento pode ser explicado pelo fato da cultura da soja ter sido inserida no Brasil concomitantemente com o avanço da agricultura empresarial sobre os cerrados, ou seja, a partir de 1970. Outrossim, destacam Castro e Fonseca (1995), foi a difusão de tecnologia relativamente igualitária entre os organismos de pesquisa, na sua grande maioria do governo (como o caso da EMBRAPA), que permitiu que um mesmo pacote tecnológico fosse adotado pela maior parte dos sojicultores. Como destaque em termos absolutos, em 20 anos safras (de 79/80 à 98/99), os rendimentos médios da região Centro-Oeste tiveram incremento acima de 1 (uma) tonelada por hectare (saindo de 1,66 t/ha em 79/80 para 2,70 t/ha em 98/99 - Tabela 10 no Anexo A).

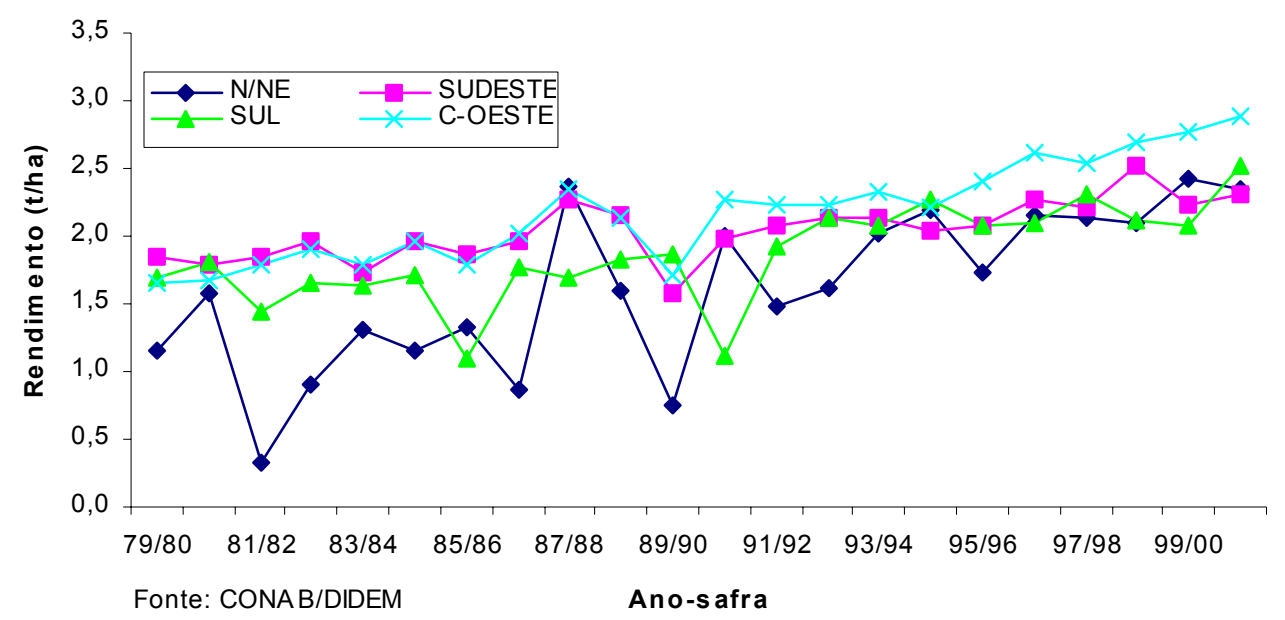

Figura 3 - Evolução dos rendimentos (t/ha) da cultura nacional de soja nas regiões Norte/Nordeste, Sul, Sudeste e Centro-Oeste, de 79/80 a $00 / 01$ 
Enquanto a soja cresceu no país sobre o cunho da grande propriedade agrícola, tecnificada e empresarial, o milho não teve a mesma prosperidade. Porém não no Centro-Oeste. Lá o milho seguiu os passos da soja, notadamente a partir da década de 90. E essa é uma das razões básicas que fazem com que os rendimentos médios do milho na região Centro-Oeste sejam bastante superiores à média do Brasil (ver Tabelas 11 e 12 no Anexo A).

Analisando-se as Tabela 11 e 12 no Anexo A, que expõem o desempenho do milho no Centro-Oeste e nas outras regiões do Brasil nas primeira e segunda safras, respectivamente (em termos de área, rendimento e produção), visualiza-se que a cultura ganhou relevância a partir da década de 90, após modesto comportamento nas 2 décadas anteriores. A Figura 4, que traz a evolução da participação de cada região na safra total de milho nas décadas de 80 e 90, ilustra melhor esta situação.

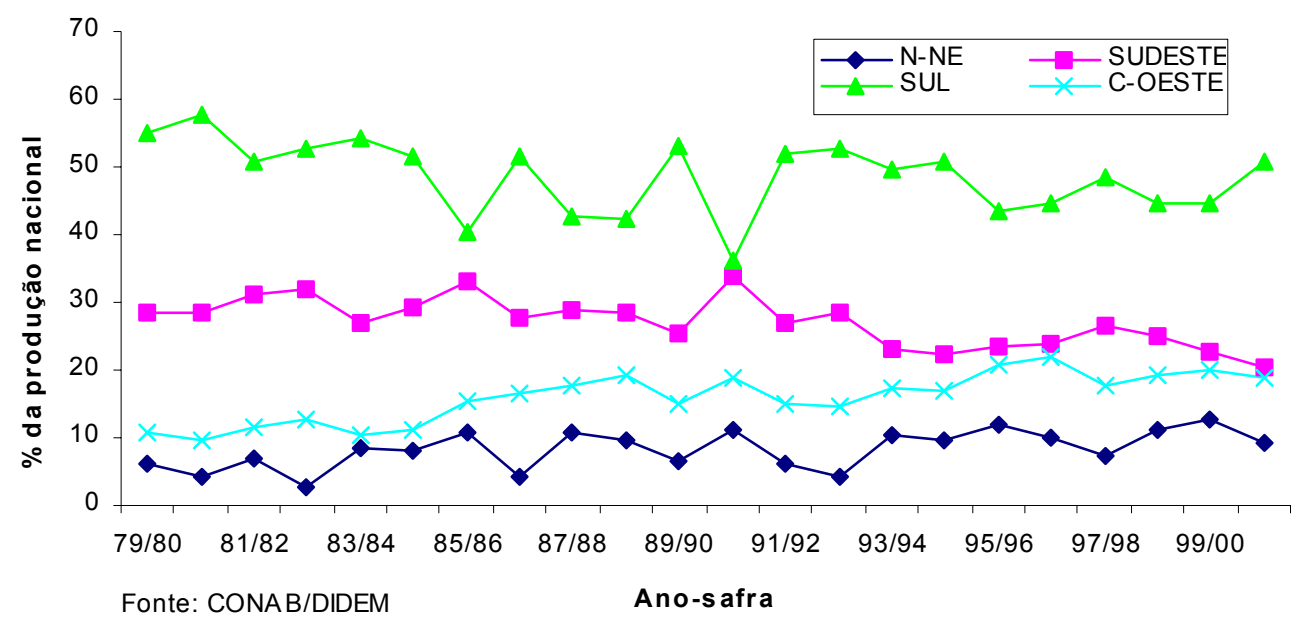

Figura 4 - Evolução da participação relativa das regiões Norte/Nordeste, Sul, Sudeste e Centro-Oeste na safra brasileira de milho, de 79/80 a $00 / 01$

Esta performance favorável da produção do milho no Centro-Oeste foi sentida através de dois condicionantes básicos. Primeiramente, através dos constantes ganhos de rendimento médio observados ao longo da década de 90 para a safra de 
verão ${ }^{11}\left(1^{\mathrm{a}}\right.$ safra) (Figura 5) e em segundo lugar, o incrível crescimento da $2^{\mathrm{a}}$ safra de milho (conhecida como "safrinha") tanto em área como em rendimento (Tabelas 11 e 12 no Anexo A). Assim, de 1980 até o final da década de 90, a produção de milho no Centro-Oeste pulou de cerca de 2,1 milhões de toneladas para 6,4 milhões de toneladas no ano de 2000 (somando-se primeira e segunda safras).

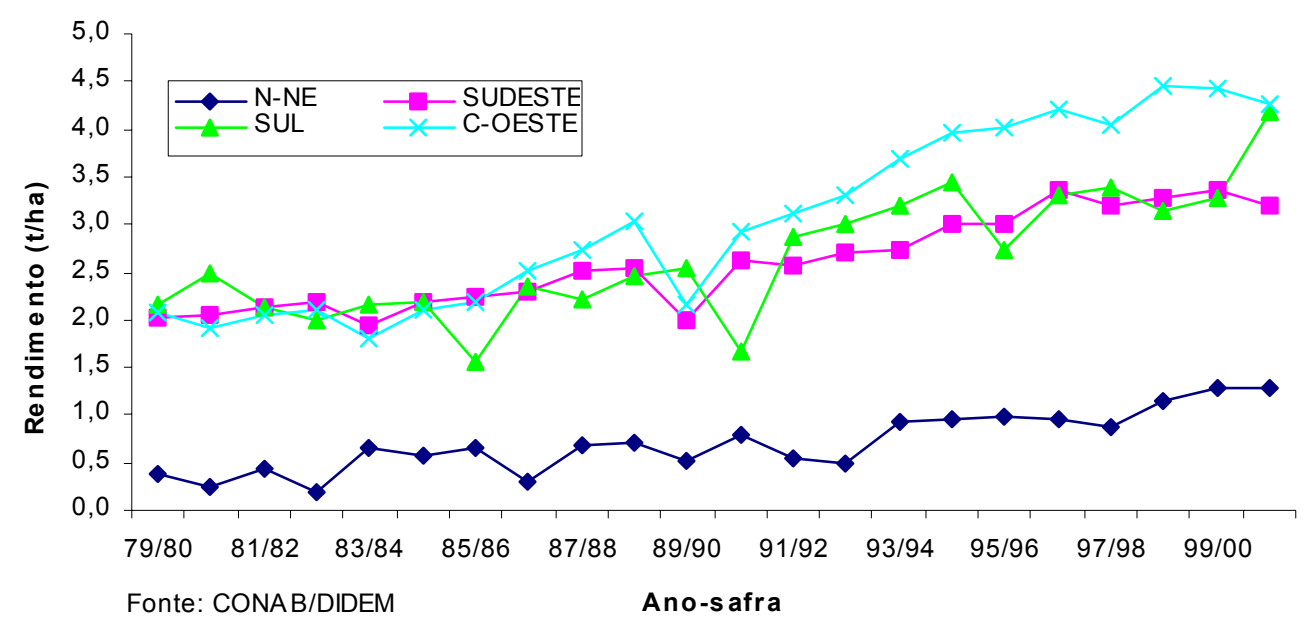

Figura 5 - Evolução dos rendimentos ( $\mathrm{t} / \mathrm{ha}$ ) da cultura nacional de milho na $1^{\mathrm{a}}$ safra, nas regiões Norte/Nordeste, Sul, Sudeste e Centro-Oeste, de $79 / 80$ a $00 / 01$

À grande importância que a safrinha passou a ter na oferta total de milho, não só no Centro-Oeste como também em todo o país, Helfand e Rezende (1998) atribuem à crescente utilização da técnica de plantio direto na cultura da soja. A rotação de uma leguminosa no verão - a soja - com uma gramínea no inverno - o milho - teve um casamento providencial. No entanto, a opção do milho como a gramínea de inverno consolidou-se no início da década de 90 quando ocorreu a desregulamentação da cultura do trigo. Sem subsídios, o trigo perdeu força à competição externa (principalmente da Argentina e Canadá) tendo sua área drasticamente diminuída no Brasil e parcial e gradualmente substituída pelo milho no inverno. O rápido crescimento da "safrinha",

\footnotetext{
${ }^{11}$ Estes ganhos de rendimento na década (90) grifam a ampla diversidade de padrões tecnológicos que o milho apresenta no Brasil.
} 
principalmente nas regiões Sul e Centro-Oeste, pode ser visto na Tabela 12 no Anexo A e a importância relativa desta última região no total produzido, na Figura 6.

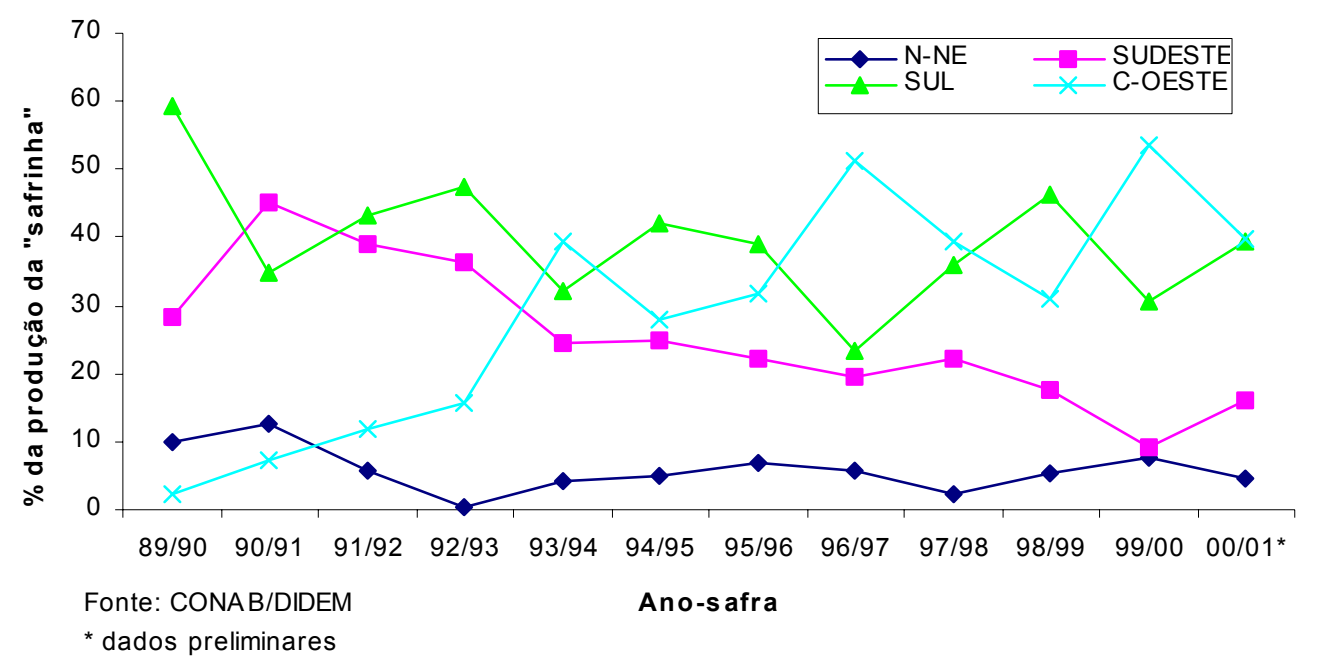

Figura 6 - Evolução da participação relativa das regiões Norte/Nordeste, Sul, Sudeste e Centro-Oeste na "safrinha" de milho, de 89/90 a $00 / 01$

Em suma, a relevância que a região Centro-Oeste representa atualmente (safra 99/00) na produção nacional de grãos pode ser sintetizada pelos $20 \%$ da produção total de milho, com apenas $15,5 \%$ da área ocupada por este cereal, e pelos $46 \%$ da produção nacional de soja com 40,8\% da área destinada a esta cultura.

Todavia, enquanto a soja parece já ter se consolidado no Centro-Oeste brasileiro, o mesmo não pode ser dito para o milho. De acordo com o trabalho de Helfand e Rezende (1998), o milho é dependente da soja e tem sua evolução na região trilhada na esteira da oleaginosa, principalmente pelo fato de ser uma das melhores opções (quando não a única) de rotação de culturas. Além disso, o milho é uma cultura que sofre como poucas as adversidades do mercado. Observa-se que em anos ruins de preço, a queda na produção na safra seguinte é certa. A instabilidade da produção de milho, porém, não é característica somente da região Centro-Oeste. O Brasil como um todo sofre deste problema.

Todo este crescimento agrícola do Centro-Oeste, fazendo com que a região, em cerca de 30 anos, passasse de projeto produtivo para ofertante de cerca de $1 / 3$ 
da safra brasileira de grãos, criou um efeito multiplicador para frente e para trás. Assim, foi justamente baseada nas sinergias com as culturas da soja e do milho que se evolui a atividade agroindustrial, notadamente a do complexo grãos-carne no Centro-Oeste brasileiro.

\subsubsection{Da agricultura ao agronegócio}

É perfeitamente compreensível que uma atividade básica, primária como a agricultura, atraia para perto de si elos a montante (como empresas dos setores de fertilizantes e corretivos químicos, sementes, agroquímicos, maquinário agrícola, etc.) e a jusante (como empresas processadoras de grãos, abatedouros de frango e suínos, de beneficiamento de alimentos, madeireiras, etc.).

No tocante às atividades a jusante da agricultura, Wilkinson (1996), distingue duas dinâmicas distintas de agroindustrialização. A primeira seria uma simples extensão da atividade agrícola. A sua forma típica seria um empreendimento artesanal com escalas determinadas pela produção local, exibindo uma relação passiva face à agricultura. Como a atividade agroindustrial seria apenas uma etapa na frente da preparação do produto agrícola para o mercado, não haveria transmissão de progresso técnico para a agricultura.

Por outro lado, o segundo tipo de dinâmica, representa uma "intervenção externa na agricultura para adequá-la a novas oportunidades de mercado" (id. ibid., p. 105). Esta dinâmica diferenciada leva, segundo o autor, a diferentes tipos de articulação entre a agricultura e a agroindústria, influenciada ainda pelas especificidades técnicas e edafoclimáticas de cada produto. Neste caso, há por parte da agroindústria a busca de condições mais favoráveis no controle de transferência de tecnologia e de abastecimento de matéria-prima.

No caso da região Centro-Oeste, o desenvolvimento da agricultura foi um processo mais concentrado e intensivo que a expansão da fronteira agrícola por estados do Sul nas primeiras décadas do século passado. Esta característica mais intensiva da exploração do espaço rural do Centro-Oeste fez com que, a partir de meados da década de 80, o crescimento da agricultura ocorresse de forma quase simultânea com a 
ampliação de atividades do agronegócio, favorecendo a transferência de tecnologia do setor secundário (indústria de transformação) para o setor primário da produção (agricultura).

Entretanto, a instalação de empresas agroindustriais no Centro-Oeste, segundo Castro e Fonseca (1995), não é um processo recente se analisarmos, principalmente, atividades relacionadas ao beneficiamento primário de produtos como arroz, milho, madeira, abate de animais, etc. O que se pode dizer que é relativamente novo na região "é a presença de empresas agroindustriais de grande porte que estendem as suas operações ao mercado de commodities, de um lado, e ao mercado interno, de outro, integrando em nível regional duas cadeias produtivas, grãos e carnes, com resultados extremamente dinâmicos para a região" (id. ibid., p. 5).

Wilkinson (1996) também destaca que o avanço da fronteira pelos cerrados está consolidando um agricultura em grande escala, produtora de grãos e oleaginosas que busca uma verticalização para frente no conjunto de carnes.

Assim, é exatamente nas sinergias com a produção de soja e milho que se estabelece um novo paradigma produtivo dos cerrados: a expansão da fronteira agroindustrial. O que era fronteira agrícola há 30 anos atrás, não mais o é. Progrediu para uma nova fronteira. Para uma fronteira do agronegócio.

Apesar de abatedouros de carne bovina e frigoríficos constituírem a presença mais antiga de empresas agroindustriais em estados como o Mato Grosso e o Mato Grosso do $\mathrm{Sul}^{12}$, foi alicerçado no grande dinamismo da cultura da soja, e por conseqüência nas plantas esmagadoras e processadoras, que estas atividades se desenvolveram no Centro-Oeste (Castro e Fonseca, 1995).

As autoras (id. ibid.) comentam, nesse sentido, que a década de 80 foi particularmente importante para a região Centro-Oeste, pois se de um lado consolidou a região como importante centro produtor de soja no país (produzindo cerca de $40 \%$ da produção nacional), por outro trouxe grandes grupos atuantes no mercado de

\footnotetext{
${ }^{12}$ Como o caso da Sadia, de acordo com Castro e Fonseca (1995).
} 
commodities que passaram a investir em armazenamento, logo seguido por inversões em atividades de esmagamento.

Para se ter uma idéia de números relativamente recentes, dados levantados pela pesquisa de Castro e Fonseca (1995) mostram que as esmagadoras de soja localizadas na região dos cerrados possuíam, em 1992, 19\% da capacidade de esmagamento total do Brasil, em toneladas/dia na planta.

Em virtude do elevado capital imobilizado em silos, armazéns, planta esmagadora, as empresas processadoras de soja, ou ainda, ligadas ao complexo soja da região Centro-Oeste, buscaram a diversificação de suas atividades. Entre óleo refinado de soja, milho, óleo refinado de milho, margarinas, o processo de diversificação da agroindústria esmagadora e processadora de soja no Centro-Oeste reproduz o processo de integração com atividades de processamento de carne já ocorrido no Sul do país (Castro e Fonseca, 1995) ${ }^{13}$.

Empresas como a Ceval e Sadia, citam Castro e Fonseca (1995), passaram a procurar novas oportunidades de lucros provenientes da conjugação das duas cadeias, de grãos e de carnes, na região Centro-Oeste.

Para promover a associação entre estas duas cadeias, as agroindústrias deste complexo especializaram-se na fabricação de alimento animal para a produção integrada $^{14}$ de aves e suínos, sendo que a sinergia ${ }^{15}$ desse processo pode ter partido do processamento de soja em direção ao abate de aves e suínos, como o caso da Ceval, ou as próprias empresas do mercado de produtos cárneos industrializados, como os casos da Sadia e da Perdigão, acumularam atividades do complexo soja.

${ }^{13}$ Lazzarini et al. (1996) complementam este comentário dizendo que foi justamente a política brasileira da década de 70 que estimulou investimentos em plantas de processamento de soja, dando mais tarde início ao processo de adição de valor ao farelo através da produção de ração e, consequentemente, da produção de carne suína e avícola.

${ }^{14}$ Entende-se por produção integrada ou integração vertical um relacionamento mais íntimo entre elos de uma cadeia através de contratos específicos de produção-fornecimento entre cooperante e cooperado, retratando o caso das integrações de grandes abatedouros e frigoríficos (Saboya e Marques, 1999).

${ }^{15}$ A sinergia pode significar, por exemplo, uma economia de escopo à medida que uma esmagora de soja se verticaliza em direção à produção de alimento animal e/ou engorda de aves e suínos. Já no caso das agroindústrias que já produziam aves e/ou suínos, a sinergia com a autosuficiência de farelo de soja advém do próprio ganho de eficiência que a empresa obtém ao internalizar a produção de um insumo considerado de suma importância. 
Independente do caminho, a estratégia comum de auto-suficiência na produção de farelo destinada às rações de seus cooperados pelas três maiores integradoras do Brasil, Sadia, Perdigão e Ceval, na ordem (Lazzarini et al., 1996), parece indicar a sinergia existente entre o processamento de soja e a integração vertical de aves e suínos.

Em relação à região Centro-Oeste, "as sinergias derivadas da integração das duas cadeias produtivas (grãos e carnes) mostraram-se particularmente atraentes em face da possibilidade de obtenção da ração a baixo custo" (Castro e Fonseca, 1995, p.7).

Vale a pena esclarecer que o menor custo de produção da ração nas plantas das grandes integradoras ou empresas comerciais que participam do mercado localizadas na região Centro-Oeste, se deve em parte pelo fato dessas empresas localizarem-se próximas aos locais de cultivo, diminuindo os dispêndios com transporte, e em outra parte aos próprios preços mais baratos do milho e da soja (e portanto do farelo), principais itens de custo do alimento animal ${ }^{16}$, em relação às demais regiões produtoras.

Aprofundando nesta discussão, Helfand e Rezende (1998, p.1) comentam haver realmente uma opinião generalizada de que a região Centro-Oeste, por "produzir grãos mais baratos que os estados onde hoje se concentram as atividades de aves e suínos - especialmente Rio Grande do Sul e Santa Catarina -, poderia ter vantagem comparativa nessas atividades da agroindústria" e estar promovendo a atração de empreendimentos. De fato os preços pagos pelo milho no Centro-Oeste têm sido historicamente inferiores ao da região Sudeste basicamente por dois motivos: primeiramente porque os custos unitários de produção (por tonelada) são relativamente mais baixos em virtude do maior rendimento das lavouras; segundo, pelo fato de a região ser exportadora líquida de milho e soja, seja para o consumo nos principais

\footnotetext{
${ }^{16}$ Segundo Lazzarini et al. (1996), o milho contribui com cerca de 40 a $45 \%$ dos custos totais e o farelo de soja, com 25 a $30 \%$, uma vez que os dois ingredientes representam, respectivamente, cerca de $60 \%$ e $20 \%$ da ração balanceada (Saboya e Marques, 1999).
} 
centros como para a exportação, os preços lá praticados têm descontado uma parcela referente ao valor frete ${ }^{17}$.

Esta "opinião generalizada", de fato, aparece na grande maioria dos trabalhos que fazem referência ao assunto. De maneira geral, não se pode negar que regiões mais remotas, como o caso dos cerrados, sofram "substancial desvantagem em relação a custos de transportes que reduzem consideravelmente o preço líquido recebido pelos produtores" (Cunha et al., 1994, p. 60), fazendo com que os preços negociados tenham um deságio em relação aos grandes centros de consumo. Castro e Fonseca (1995), visualizam nas sinergias da integração das duas cadeias produtivas (grãos e carne) a possibilidade de produção de ração de baixo custo. Lazzarini et al. (1996, p.596), analisando as estratégias da indústria nacional de nutrição animal, salientam a "tendência de mudança no pólo produtor de grãos para o Centro-Oeste. Nesta região, a terra é mais barata, o que permite um aumento de escala das fazendas", devendo haver assim, "expansão da produção de rações no nível de fazenda". Wilkinson (1996), por intermédio de entrevistas, comenta que empresas privadas dos setores de aves e suínos estão de fato manifestando interesse em dirigir novos investimentos aos cerrados. Nesta mesma linha de raciocínio, Farina (1997, p.109) expõe que "com o deslocamento da produção de soja e milho para a região do Centro-Oeste, os novos investimentos em avicultura têm sido direcionados para essa região".

Em resumo, a idéia básica é a de que os preços mais baratos das matériasprimas básicas (milho e farelo de soja) para o arraçoamento animal estariam atraindo as cadeias de aves e suínos para regiões de cerrado.

Um exemplo atual deste novo paradigma produtivo é o Projeto Buriti da Perdigão em Rio Verde-GO, em linhas bem distintas do conduzido no Sul do país. Faveret Filho e Paula (1998), analisando o projeto, salientam que a escolha do local pela Perdigão deveu-se à disponibilidade de grãos (milho e soja), oferta e qualidade de mão-

\footnotetext{
${ }^{17}$ Vale salientar que o próprio crescimento da atividade de produção de aves e suínos no Centro-Oeste, e por consequência o aumento da demanda por farelo de soja e milho, vem fazendo com que regiões antes exportadoras líquidas de grãos, como o caso do Sudoeste goiano, desenvolvam mercados locais, o que per se acarreta em aumento dos preços das matérias-primas.
} 
de-obra, disponibilidade de carne bovina, incentivos fiscais e condições climáticas. Assim como outros projetos desenvolvidos no cerrado de natureza semelhante, apontam para uma nova geografia do setor, baseada na proximidade com áreas fornecedoras de matérias-primas a baixo custo.

Nessa tônica, o trabalho de Helfand e Rezende (1998) revela, de acordo com a metodologia e tipo de dados utilizados, alguns fatos importantes. Primeiramente, ao analisarem a estrutura de preços do milho no Brasil (o principal item no custo da ração), os autores identificaram, para o período de 90/95, quatro regiões homogêneas em termos de preço, e que se diferenciaram progressivamente entre si: $1^{\mathrm{a}}$ ) Paraná e CentroOeste; $2^{\mathrm{a}}$ ) Rio Grande do Sul e Santa Catarina; $3^{\mathrm{a}}$ ) São Paulo e Minas Gerais; 4 ) Espírito Santo, Rio de Janeiro, Nordeste e Norte. Como conclusão preliminar desta análise, os autores comentam que os diferenciais de preços realmente indicam a economia de custos de aquisição de milho no Centro-Oeste quando comparada à região Sudeste. “O mesmo não pode ser dito para o Sul. (...) Então, se a produção animal deve migrar do Sul para o Centro-Oeste, é provável que o seja por outras razões que não o preço do milho" (id. ibid., p.11).

Em suma, a indústria de transformação em geral, ou especificamente as cadeias produtivas de aves e suínos, são orientadas via de regra pela facilidade de aquisição de suas matérias-primas básicas. Quando as matérias-primas não são recursos naturais, oriundos de jazidas ou reservas naturais, a alteração espacial da produção influi significativamente não só na tomada de decisões de investimentos vindouros como também na reorganização estratégica da base (agro)industrial instalada.

Entretanto, o universo de variáveis que norteiam os investimentos, bem como a sua localização, não se restringe ao estudo da dinâmica das principais matériasprimas necessárias para a transformação do produto. Muitas vezes são estímulos externos que decidem a favor da localização dos projetos de investimento das empresas. 


\subsubsection{A questão regional}

A intensificação das atividades tanto agrícola como agroindustrial em regiões de cerrado não foi um processo isolado e casuísta. Ele germinou e desenvolveuse nos meandros de políticas específicas para o "preenchimento de espaços vazios", chamadas de políticas de desenvolvimento regional. Tais políticas constituíram-se no principal vetor que desencadeou profundas mudanças na estrutura produtiva agrícola brasileira, principalmente a de grãos. Atualmente produzindo cerca de $46 \%$ da safra anual de soja e $20 \%$ da safra de milho, o Centro-Oeste brasileiro, ou as regiões de fronteira agrícola, passaram a representar um paradigma produtivo da agroindústria a jusante que, atraída por vantagens comparativas, estaria localizando novos investimentos nessa região.

Entretanto, resumir a capacidade de atração de novos investimentos a fatores locacionais básicos como a disponibilidade de matérias primas básicas, incorrerse-ia na ignorância de todo um contexto político-econômico que influenciou e influenciará a tomada de decisões dos investimentos dos diferentes segmentos produtivos no Brasil.

Além disso, o processo de desconcentração produtiva a partir da mudança de enfoque que as políticas de desenvolvimento regional proporcionaram não afetou somente a agricultura e o agronegócio. Estes dois setores foram apenas alguns dos personagens desta mudança da distribuição espacial de várias atividades produtivas.

Assim, compreender a evolução da "questão regional" brasileira faz-se indispensável para a inferir sobre a dinâmica locacional do agronegócio na região Centro-Oeste, notadamente das cadeias de aves e suínos.

\subsubsection{Concentração e desconcentração econômica no Brasil nos últimos 30 anos}

Buscando a essência da importância da questão regional no Brasil, Cano (1994) resgata, no período pós-30, o início de sua discussão e sustentação política já desde o primeiro Governo Vargas, principalmente a partir do Estado Novo, e efetivamente no segundo Governo Vargas. No entanto, "a temática adquire um corpo de 
maior reflexão, de teorização, de ação política e de ação política econômica principalmente após 1960”, quando as chamadas políticas de desenvolvimento regional passaram a figurar oficialmente na agenda do Estado (id. ibid., p.312).

A implantação permanente de políticas de desenvolvimento regional fundamentou-se nas reivindicações por maior equidade regional e federativa, reforçadas no final da década de 50 pela incrível concentração produtiva na região metropolitana de São Paulo (Cano, 1997).

De maneira geral, todo o país experimentou uma das maiores taxas de crescimento econômico do mundo capitalista entre 1930 e 1970; porém São Paulo crescia a taxas anuais superiores à média nacional. A maior articulação dos principais centros produtivos com outras regiões passou a ser intensificada a partir de 1970, quando, dentre outros fatores, as políticas de desenvolvimento regional promoveram incentivos para o capital produtivo migrar para regiões de fronteira ${ }^{18}$. A matriz industrial consolidada e concentrada exigia esforço periférico de melhor utilização de nossa base de recursos naturais (id. ibid.).

Assim, o período de 1970 a 1985, dentro de uma visão compartilhada por vários autores (Cano, 1997; Diniz, 1995; Pacheco, 1999 e Perobelli, 1996), marcou uma fase de reversão da polarização no estado de São Paulo e de desconcentração produtiva para várias regiões do país. Além do Estado como indutor do processo, o aparecimento de deseconomias de aglomeração ${ }^{19}$ na Região Metropolitana de São Paulo reforçou o movimento de espraiamento dos investimentos (Perobelli, 1996). Dentre os vetores que contribuíram para essa dinâmica, Diniz (1995) destaca o importante papel desempenhado pela atividade agropecuária que atingiu as regiões do Centro-Oeste brasileiro, sendo logo em seguida acompanhada de investimentos agroindustriais.

Já num período seguinte, de 1985 a 1995, houve uma inflexão deste movimento e até mesmo uma aparente reconcentração (Cano, 1997). Para Diniz (1995) e

\footnotetext{
18 Outros determinantes do processo de desconcentração produtiva são melhores detalhados em Cano (1997) e Diniz (1995).

19 As deseconomias de aglomeração podem ser induzidas por limitações técnicas, fim das economias internas, e o aparecimento de deseconomias externas, tais como aumentos dos custos dos terrenos, aluguéis, salários, entre outros (Pacheco, 1999 e Perobelli, 1996).
} 
Perobelli (1996), esta segunda fase faria parte de um processo de desconcentração para uma área com limites claros, representada pelo polígono Belo Horizonte - Uberlândia Londrina/Maringá - Porto Alegre - Florianópolis - São José dos Campos - Belo Horizonte.

Sobre esta segunda fase, de reversão da despolarização produtiva no estado de São Paulo, Cano (1997) comenta que a "crise da dívida", somada às políticas neoliberais fizeram com que o crescimento econômico de São Paulo (e do Brasil) se tornasse, na média, irrisório e, assim, o arrefecimento da acumulação dificultasse também o crescimento periférico.

Lemos (1996) complementa que, na década de 90, o novo padrão tecnológico e conseqüente emergência de novos setores industriais está tendendo a restringir o processo de desconcentração macroespacial. A reestruturação industrial em função da política de abertura comercial e das mudanças tecnológicas organizacionais da indústria nacional (tecnologias de processo e paradigma da informação) auxilia as aglomerações mais dinâmicas (em geral contíguas ao pólo industrial da Região Metropolitana de São Paulo). A presença de complexa infra-estrutura de transportes e telecomunicações, proximidade a centros de geração e desenvolvimento tecnológico (parques, pólos, incubadoras, etc.) e centros de produção científica nesses pólos tecnológicos, são sem dúvida indutores de um redesenho da distribuição geográfica dos setores mais dinâmicos, acarretando numa desconcentração restringida da produção industrial.

Esses setores mais dinâmicos, intensivos em tecnologia, microeletrônica e telecomunicações, que passam então a demandar pólos tecnológicos para localização de novas plantas, têm reduzida ou inexpressiva demanda de recursos naturais. Ou seja, esta dinâmica recente não reflete os setores ou indústrias que têm forte dependência de recursos naturais e/ou matérias-primas básicas produzidas regionalmente, como o caso das agroindústrias. Como ilustração, Cano (1997) atribui à continuidade da desconcentração agrícola, induzindo novos projetos agroindustriais regionalizados (com destaque aos cerrados e algumas "manchas" irrigadas do Nordeste) como um dos fatores 
que contribuíram para efetivas manifestações de desconcentração no período pósinflexão do movimento de despolarização (ou seja, pós-1985).

No entanto, apesar do forte apelo sinérgico de proximidade das agroindustriais com as fontes de matérias-primas, outros requisitos são, em determinadas circunstâncias, de igual ou superior importância na escolha dos sítios de investimento dessas atividades, principalmente quando se trata de regiões de fronteira, distante dos grandes centros de consumo, como é o caso da região Centro-Oeste. Assim, mesmo não classificando as empresas dos complexos aves e suínos neste grupo de empresas tecnológicas, deve haver, um equilíbrio entre a facilidade de aquisição de matérias primas e a infra-estrutura local e de acesso aos mercados.

\subsubsection{Os vetores locacionais da avicultura e suinocultura}

Seria muita pretensão discriminar todos os quesitos que são levados em consideração na escolha do sítio de produção por uma empresa. Além de haver grande variação de enfoque entre empresas, as atenções se alteram ao longo do tempo. O que se pretende, então, é destacar os principais condicionantes da localização das empresas dos agronegócios de aves e suínos, destacando não apenas as variáveis tidas como básicas, mas também outras de grande relevância na tomada de decisões de tais empresas.

Já foi salientada, em itens anteriores, a grande importância das matériasprimas localizadas, milho e farelo de soja, na produção de aves e suínos. Para se ter uma idéia, cerca de $90 \%$ do volume total das rações é composto por milho e farelo de soja (Saboya e Marques, 1999). Helfand e Rezende (1998), com o auxílio de informações fornecidas pela EMBRAPA, calculam que a ração representa $67 \%$ do custo da produção de frangos vivos e 55\% do custo de frangos abatidos (sendo que para suínos estas relações caem um pouco). Todavia, como aproximadamente $60 \%$ da composição da ração é milho, considera-se que o cereal seja o principal item do custo de animais vivos prontos para o abate (aves e suínos). Além disso, como o milho apresenta menor valor unitário que os demais ingredientes da ração, os custos de movimentação são proporcionalmente mais elevados, justificando ainda mais a proximidade às regiões produtoras. 
Sem dúvida, um segundo fator de grande importância nas decisões locacionais das atividades produtivas de aves e suínos é o fator mão-de-obra, como o é para a grande maioria dos outros segmentos do agronegócio. Porém, há que se fazer uma divisão da sua utilização devido aos moldes em que a avicultura e suinocultura vêm se desenvolvendo. Primeiramente, considerando-se ao nível das granjas, geralmente unidades familiares que engordam os animais até o peso de abate, o emprego da força de trabalho se restringe quase que exclusivamente à família. Apenas grandes granjas contratam mão-de-obra extra.

Da outra ponta, os abatedouros/frigoríficos, por si só, são intensivos em mão-de-obra nas plantas de processamento. No entanto, há que se considerar se estas empresas são independentes ou integradoras. No caso das grandes integrações ou cooperativas - complexos produtivos que representam a quase totalidade da produção sulina de frangos e suínos -, a figura da mão-de-obra externa à planta de processamento, ou seja, o integrado ou cooperado, é elemento chave neste sistema coordenado de produção. Assim, a detecção de "mão-de-obra barata e abundante", chavão que geralmente é associado a regiões de fronteira, perde importância a atributos qualitativos que expressam o perfil do integrado.

Um trabalho desenvolvido por Talamini, Santos Filho e Canever (1998) que estuda o comportamento das atividades produtoras de aves e suínos quanto às vantagens da novas regiões produtivas no Centro-Oeste, chega a interessantes resultados quanto às vantagens comparativas da região vis-a-vis o sul do país. Os autores (id. ibid.) consideraram que um dos fatores que limita a vantagem comparativa da produção integrada no Centro-Oeste é justamente o maior nível de remuneração exigido pelos integrados para se manterem no sistema ${ }^{20}$. Retratam, assim, que o perfil do integrado destas regiões difere substancialmente do perfil do minifundiário do sul, na maioria das vezes colono imigrante, predisposto à lucratividade limitada que a atividade oferece. Já

\footnotetext{
${ }^{20}$ De acordo comos autores (Talamini, Santos Filho e Canaver, 1998, p. 230), as economias com os custos de produção provenientes principalmente do menor custo da ração, não implicam em menores preços pagos pelo produto acabado, "pois estes últimos decorrem das condições de oferta e demanda assim como das expectativas dos produtores quanto à rentabilidade mínima que os estimularia a entrar e a se manter na atividade".
} 
no Centro-Oeste, o perfil do produtor agropecuário é sobremodo distante a esse, principalmente quando se considera que é um empreendedor e não apenas um produtor rural.

Um terceiro vetor de forças que direciona e atrai investimentos a uma dada região é sem dúvida a infra-estrutura. Porém, o que de fato é infra-estrutura? Peck (1996) estudando a atração de novos investimentos internos pela infra-estrutura local, a define como as facilidades que fornecem as bases coletivas (na idéia de que são usadas por uma ampla variedade de atividades e usuários individuais) e de integração (fornecendo os meios necessários por onde as atividades econômicas podem interagir) à atividade econômica. $\mathrm{O}$ autor (id. ibid.) enfatiza também a importância particular que um contínuo processo de renovação e melhora da infra-estrutura desempenha no desenvolvimento de regiões que são econômica e geograficamente periféricas, como o caso da região Centro-Oeste.

Peck (1996) ainda comenta que a infra-estrutura raramente é fator decisivo na escolha do local produtivo (sendo necessária mas não suficiente). Entretanto, demonstra em seu trabalho de que, na década de 90, pelo menos na Inglaterra, os programas de desenvolvimento regional estão se tornando cada vez mais flexíveis, onde a infra-estrutura funciona como um fator de atração construindo "sob encomenda" o espaço físico às firmas que se instalarão na região ${ }^{21}$. É como se fosse uma aposta de organizações autônomas (substitutas do Estado como fornecedor de infra-estrutura) na expectativa de que o setor privado vá subseqüentemente responder a esses estímulos através do deslocamento ou reorientação da distribuição espacial de suas atividades.

Enriquecendo esta análise, o trabalho de Moore, Tyler e Elliott (1991) sobre a influência do desenvolvimento regional e infra-estrutura na localização de pequenas e médias empresas na Europa, detecta a importância atribuída ao fator infraestrutura (sistematizada nos seguintes atributos: gás/eletricidade/água, transporte público, estradas, rodovias, aeroportos, educação/treinamento, meio ambiente,

${ }^{21}$ Ao contrário do que vinha contecendo nas décadas de 70 e 80 , onde a produção do ambiente físico era mero resultado dos objetivos de programas de desenvolvimento regionais pré-estabelecidos (Peck, 1996). 
moradia/saúde, comércio/lazer) na escolha do local de instalação ou relocalização de novas plantas produtivas. Entretanto, concluem que a infra-estrutura parece só despontar como um problema depois que as firmas estão estabelecidas na área e passam a sofrer com as dificuldades encontradas.

Como um quarto vetor de orientação da localização da avicultura e suinocultura no Centro-Oeste deve-se considerar a variável "programas de desenvolvimento regional". Os papéis das políticas de desenvolvimento regional para o crescimento das atividades agropecuárias na região Centro-Oeste já foram retratados no item 2.1.1.2.1. À semelhança de tais políticas, é esperado que quaisquer mecanismos que visem o desenvolvimento de atividades do agronegócio, que estiveram ou ainda estão em vigência, atraiam empresas do mesmo modo que aquelas atraíram produtores rurais.

Os incentivos fiscais constituem-se num quinto vetor de atração. $\mathrm{Na}$ verdade, os incentivos fiscais às empresas são frutos da renúncia fiscal, total ou parcial, dos estados, principalmente ao imposto sobre circulação de mercadorias e serviços (ICMS), dando origem ao que se consagrou chamar de "guerra fiscal". De acordo com Varsano (1997, p.3), "as armas usadas na guerra fiscal do ICMS visam atrair empreendimentos para o território da unidade que as utiliza", gerando assim uma situação de conflito na Federação. O autor (id. ibid.) salienta que é a própria sistemática de tributação das operações interestaduais via ICMS que estimula a concessão do incentivo, pois do ponto de vista de cada estado ele não é um imposto sobre o consumo, mas sim um híbrido que tributa tanto a produção como o consumo.

Apesar da guerra fiscal ser travada à revelia da Lei Confaz ${ }^{22}$, ela se tornou um mecanismo difundido de atração de investimentos para dentro das fronteiras dos estados. Como consequência, acaba por beneficiar os estados mais desenvolvidos, capazes de arcar com o ônus das renúncias sem perder qualidade na geração de serviços e infra-estrutura, condições observadas pelas empresas para confirmar os investimentos.

Varsano (1997) expõe que, no final das contas, todos os estados saem perdendo com a guerra fiscal. Quanto às empresas, há as que ganham e as que perdem

\footnotetext{
${ }^{22}$ Para mais informações, ver Varsano (1997).
} 
com a guerra fiscal. Entretanto, esta força externa, por muitas vezes, é suficiente para desviar o curso de um investimento, mascarando a força de outros vetores tidos como básicos na decisão locacional.

O sexto e último vetor a ser levado em conta é a questão ambiental. Esta, referir-se-ia às maiores facilidades de manejo dos dejetos em regiões de fronteira, devido, principalmente, conforme comentam Talamini, Santos Filho e Canever (1998), ao relevo plano, estruturas fundiárias maiores encontradas em regiões de cerrado. $\mathrm{O}$ problema de tratamento de dejetos é particularmente mais agravante para a suinocultura do que para a avicultura. Apesar de acreditar-se que num futuro bastante próximo já estejam difundidas técnicas que amenizem e/ou erradiquem este problema em regiões de elevada concentração produtiva, como é o caso do oeste catarinense, a própria restrição de espaço físico para expansão da atividade coaduna-se com esta restrição. Assim, a questão ambiental pode ser vista tanto como um fator de atração para regiões fronteiriças como um fator de expulsão dos grandes pólos produtivos.

Pode-se dizer que estes 6 (seis) fatores locacionais anteriormente discutidos constituem-se em "macrovetores" das atividades avícola e suinícola na região Centro-Oeste. Ou seja, outras variáveis mais específicas a uma determinada situação enquadrar-se-iam em alguns destes vetores que serão considerados como capazes de explicar a problemática de localização.

Em suma, o paradigma locacional de "onde produzir" vem passando por profundas guinadas de enfoque nos últimos 40 anos e carecem de um enfoque mais holístico. Como comenta Haddad (1999), quando faz referência aos novos padrões de localização de projetos de investimentos, as vantagens comparativas das regiões para atraí-los dependerão, relativamente, cada vez menos da disponibilidade de recursos naturais ou de mão-de-obra não qualificada em abundância (fatores locacionais tradicionais), e cada vez mais da existência, na região, de serviço terciários e quaternários, centros de pesquisa, recursos humanos especializados, ambiente cultural (fatores não-tradicionais), que são geralmente negligenciados pelos modelos clássicos de localização. 
Apresentada a problemática a ser estudada, o capítulo seguinte abordará o enfoque comportamental da teoria da localização.

Entretanto, antes de aprofundar-se no referencial teórico deste estudo, há que se sublinhar a pressuposição primária deste estudo, qual seja: os preços mais baixos das matérias-primas básicas (em especial o milho) nos estados da região Centro-Oeste não são suficientes para explicar o desenvolvimento das atividades dos complexos de aves e suínos nessa região.

\subsection{REFERENCIAL TEÓRICO}

O enfoque comportamentalista da localização industrial nasceu das críticas aos modelos tradicionais de localização que tinham em seu centro um homem econômico, racional, que é otimizador. Pode-se dizer que os fatores determinantes da localização dos sítios produtivos na Teoria Clássica da Localização eram principalmente as matérias-primas (relacionadas com os custos de transporte) e a mão-de-obra.

Ao invés de se pormenorizar sobre os principais testamentos da Teoria Clássica da Localização, deixa-se no Apêndice uma resenha sobre os principais teóricos e suas contribuições para o entendimento de como os fatores tidos como clássicos podem influenciar a localização industrial.

Dessa forma, passa-se diretamente às críticas aos modelos clássicos para depois se desenvolver o enfoque comportamental da localização industrial.

\subsubsection{Críticas e considerações sobre os modelos clássicos de localização}

Sinteticamente, o traço que marca os quatro principais modelos tradicionais da localização produtiva é o papel primordial exercido pelos custos de transporte. Ora explícito em Weber e Isard na forma de minimização de custos, ora nos modelos de von Thünen e de Lösch, indiretamente nas considerações de maximização de 
receita/lucro, os custos associados ao fator transporte desempenham papel fundamental na determinação da localização das atividades econômicas (ver mais detalhes sobre os quatro modelos teóricos no Apêndice).

De fato, esta concordância da importância dos custos de transporte na localização abordada pelos modelos clássicos é bastante factível à realidade da época em que foram desenvolvidos. Nesse ponto, Norcliffe (1975) aponta para uma diminuição da utilidade de tais modelos para expressar a realidade locacional das empresas contemporâneas, justamente pelo fato dos custos de transporte virem perdendo importância ao longo dos tempos na participação dos custos totais bem como na influência da localização. Esta perda de importância pode ser sumarizada em:

a) aumento do número de empresas que trabalham com produtos de alto valor agregado e, portanto, têm pequena participação dos custos de transporte nos custos totais do produto final;

b) o uso mais eficiente de materiais, em termos de tecnologia de processos, vem fazendo com que se reduza a importância das matérias-primas na localização da planta;

c) a possibilidade de substituição de insumos tem freqüentemente reduzido restrições de transporte na localização e diminuído sua dependência a determinados insumos;

d) o desenvolvimento de tecnologias associadas ao transporte.

Tais empresas, segundo Norcliffe (1975), tornam-se relativamente desenraizadas (ou "footloose"). Assim, dependem cada vez menos de matérias-primas localizadas, e sofrem menores influências dos custos de transporte na decisão locacional. Evidentemente, para indústrias consideradas "pesadas", cujo volume de matérias-primas trabalhado é muito elevado, e para aquelas que se localizam em regiões de fronteira, distantes dos principais centros de consumo, os custos de transporte são ainda de grande relevância (observação feita pelo próprio Norcliffe, 1975, p.23, nas críticas às teorias clássicas de localização).

Um outro grupo de críticas que Norcliffe (1975) se ateve foi sobre o fator mão-de-obra, uma variável que poderia causar um desvio no ponto ótimo de mínimo custo de Weber e incorporado também por Isard após longo tratamento baseado no 
insumo transporte (informações complementares no Apêndice). A premissa básica destes autores, bem como em outras considerações dentro da teoria clássica de localização, era que à medida que se afastava da cidade (centro de consumo), os custos com pagamento de salários à força de trabalho diminuíam. Assim, o fator mão-de-obra, grosso modo, era visto como desaglomerativo, na proporção em que poderia fornecer economias mais do que proporcionais aos custos de transporte associados ao deslocamento do ponto ótimo. No entanto, para o autor (id. ibid.), está havendo uma maior igualdade de salários entre regiões, oriunda muitas vezes de apelos para reduções nas disparidades de renda ${ }^{23}$. Além disso, os modelos clássicos não ponderam os custos da força de trabalho com a sua produtividade, uma vez que regiões que apresentam baixos custos salariais podem não compensar a baixa produtividade, principalmente em atividades que demandam mão-de-obra qualificada.

Não seria surpresa alguma encontrar ainda fortes críticas em vários trabalhos (Azzoni, 1982a e 1982b; Ferreira, 1989; Kellerman, 1989a e Norcliffe, 1975) a respeito das superfícies homogêneas nos espaços econômicos de von Thünen e Lösch. Segundo Norcliffe (1975), a pressuposição de uma planície uniforme representa uma grosseira distorção da realidade. Outro problema, segundo o autor (id. ibid.) residiria na uniforme superfície de demanda considerada por Lösch e a não consideração de sombreamentos entre as várias áreas de mercado.

Estas considerações a respeito do papel dos custos de transporte, dos custos da mão-de-obra e da dependência de matérias-primas localizadas são de grande importância para a situação da problemática da localização da avicultura e suinocultura no Centro-Oeste. Principalmente porque tais atividades não estão nem no extremo da máxima dependência de fatores locacionais tradicionais, como os casos das indústrias extrativas minerais, nem no outro extremo das empresas "footloose", como por exemplo, empresas prestadoras de serviços ou intensivas em tecnologia que exclusivamente se orientam para os grandes centros urbanos.

\footnotetext{
${ }^{23}$ Certamente esta consideração não se aplica ao caso brasileiro, onde existe forte desigualdade tanto de renda como de salários entre regiões de fronteira (Norte, Nordeste e Centro-Oeste) e o eixo Sul-Sudeste de produção.
} 
Assim, é de se esperar que empresas dos complexos aves e suínos sofram consideráveis influências dos fatores locacionais clássicos. Todavia, devido às estruturas de concorrência imperfeita, muitas vezes oligopolista nos mercados que atuam, as empresas dos segmentos de aves e suínos podem, em algum momento, ter outro objetivo que não a maximização de lucros. Ou seja, há a necessidade de se incorporarem outros fatores, geralmente de caráter não-econômico, agindo como forças espúrias que desviam a localização de um possível ótimo (como por exemplo, incentivos fiscais).

Nesta tônica, Norcliffe (1975) aponta a conveniência de se tratar o problema da localização em termos de "influências locacionais", do que simplesmente custos, sintetizadas em três elementos: a disponibilidade de infra-estrutura, economias internas e externas e campos de ligações e contatos.

Por último, como os modelos da Teoria Clássica da Localização são extensões dos modelos neoclássicos da Teoria da Produção, cujo traço comum é a suposição de um comportamento otimizador por parte do agente econômico (Azzoni, 1982b) um foco de crítica a esse comportamento deu origem a considerações complementares sobre o comportamento do empresário, suas motivações e objetivos, geralmente no formato de modelos de decisão locacional. Este recente framework será discutido no item seguinte.

\subsubsection{Enfoque comportamental na localização industrial (Behavioural approach)}

Walker (1975) considera que houve um considerável desvio de atenção para um ponto de vista mais comportamental na geografia industrial desde o trabalho de McNee em $1960^{24}$ que apelava por uma "economia geográfica mais humana".

Azzoni (1982b), por sua vez, discute que foi Allan Pred em $1967^{25}$ um dos primeiros a questionar o comportamento otimizador do agente econômico por detrás dos modelos clássicos de localização, que postulavam, de forma geralmente intrínseca, a

\footnotetext{
24 MACNEE, R.B. Toward a more humanistic economic geography: the geography of enterprise. Tijdschrift voor Economishe en Sociale Geografie, n.51, p. 201-206, 1960.

${ }^{25}$ PRED. A. Behavior and Location. Lund Studies in Geography, Ser. B Human, n.27, v.2, 1967.
} 
racionalidade perfeita do tomador de decisões ${ }^{26}$. Allan Pred assume, segundo Kellerman (1989b), que os tomadores de decisões quanto à localização atentam-se mais à satisfação do que à maximização de lucros. Cada um deles corresponderia a células de uma matriz, com um eixo representando a quantidade de informação disponível e o outro a capacidade de usá-la (Figura 7). Azzoni (1982b) ensina que os limites máximos dessas dimensões $\left(\mathrm{B}_{n n}\right)$ representam perfeito conhecimento e perfeição no uso das informações, qualidades inerentes ao "homem econômico racional", personagem central dos modelos nos quais alguma otimização é suposta.

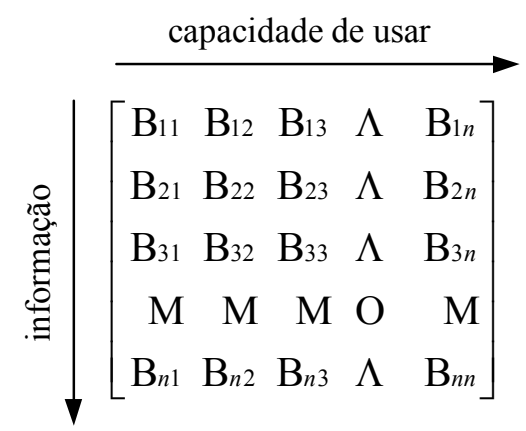

Figura 7 - Matriz comportamental de Pred (modificado de Kellerman, 1989b, p. 1435)

Com o auxílio desta matriz, instrumento muito mais conceitual do que quantitativo, ficam contemplados desde o maximizador de lucros, bem ou mal-sucedido, até os empresários que não se baseiam em motivos de ordem econômica, agindo puramente por instintos, sem, no entanto, estarem fadados ao insucesso. Dessa forma, dependendo da capacidade em usar as informações e da quantidade e da qualidade delas, o tomador de decisão ocuparia um lugar na matriz comportamental, sendo este local interpretado como um desvio das normas das Teorias de Localização.

Além da capacidade do agente econômico em avaliar, de forma perfeita, os prós e os contras, os modelos clássicos de localização apontavam sempre para um objetivo claro e definido do agente econômico. Walker (1975, p. 136) defende que "os

\footnotetext{
${ }^{26}$ Vale dizer ainda que, certamente o grande crítico à racionalidade do "homem econômico" dos modelos neoclássicos foi Herbert Simon em 1959, que contrapunha a seu "homem administrativo", que age racionalmente dentro dos limites de seus conhecimentos e de suas percepções.
} 
objetivos nem sempre são completamente econômicos" e, principalmente quando se lida com grandes organizações, não são únicos.

Entretanto, a consideração de outros objetivos que não a maximização de lucros ou a minimização de custos totais, poderia ainda ser otimizadora. A alternativa sugerida por Cohen e Cyert (1969), diz respeito não só a considerar o comportamento dos empresários como resultado da "satisfação" de certos requerimentos (ao invés da otimização de outros) mas também procurar desenvolver um entendimento do processo de tomada de decisões internamente à firma. Esta visão estaria de acordo com uma maneira diferente de encarar o problema, própria da Teoria Comportamental da Firma (Behavioural Theory of the Firm).

Como a decisão locacional é apenas uma das muitas que a firma está sujeita a ter que tomar durante o seu ciclo de vida, tal enfoque não se refere apenas a decisões no âmbito de onde se localizar. Além do mais, dentro do universo das decisões empresariais, as locacionais apresentam, segundo Azzoni (1982b), duas características que justificam ainda mais as limitações do "homem racional", quais sejam, a complexidade e a esporadicidade. O número e a heterogeneidade de fatores envolvidos, somados ao fato de muitos serem de natureza não quantitativa, conferem à decisão de escolher uma localização um caráter fortemente complexo. Quanto à segunda característica, pode-se indagar: "quantas vezes uma firma vê-se num dilema de se (re)localizar?". Na maioria das vezes a resposta seria: poucas vezes. É uma decisão nãorotineira, geralmente envolvida de incertezas.

Townroe (1972) faz questão de enfatizar, em seu estudo sobre a decisão da localização industrial através de considerações comportamentais, que o tomador de decisão se depara com um dilema e não com um problema de localização. Para isso, o autor (id. ibid.) faz uso da definição de Rapoport $(1960)^{27}$ que diz que um problema pode ser resolvido dentro das referências sugeridas pela sua própria natureza, por questões semelhantes surgidas no passado, ou através da aplicação de políticas

\footnotetext{
${ }^{27}$ RAPOPORT, A. Fights, games and debates. Michigan: University of Michigan Press. 1960.
} 
existentes. Um dilema, por outro lado, não é resolvido pelas pressuposições explícitas ou implícitas contidas na sua apresentação, mas sim requer reformulação e inovação.

Walker (1975) complementa este debate ao generalizar a firma como um ente econômico que tem alguns mecanismos adaptativos. São através deles que a firma reage às mudanças externas. Explica que uma adaptação, forçada por alguma pressão externa, pode ser puramente organizacional e não envolver nenhum tipo de modificação física. "De outro lado, pode incluir um programa de modernização ou expansão no sítio atual, uma relocalização, ou estabelecimento de algum tipo de filial ou desenvolvimento de subsidiária" (Walker, 1975, p.139 - tradução nossa). Assim, por exemplo, se um novo mercado se desenvolve a uma distância considerável da planta existente, uma nova filial pode ser construída para atendê-lo. Este seria um enfoque adaptativo-adotivo da localização industrial, usado para explicar a dinâmica locacional de indústrias manufatureiras em áreas particulares de estudo.

Concluindo a apresentação desta abordagem, Walker (1975) demonstra que nem todos os tipos de adaptações afetam à organização espacial da firma diretamente. Por exemplo, mudanças de preços quase nunca geram algum efeito, enquanto modificações no maquinário ou reorganização do pessoal mais freqüentemente causam apenas discretas modificações espaciais. Sugere, então, que o termo adaptação espacial seja reservado para os tipos de ajustamentos nos quais um grande esforço é dispendido para lidar-se com a dimensão espacial, como por exemplo, os preços dos insumos de várias fontes, o tamanho da demanda em diferentes áreas, ou as alterações nos custos de transporte.

"Como resultado de tais mudanças no ambiente, a firma pode ajustar seus padrões de relação com os bens para incrementar a lucratividade. Uma das classes de adaptação espacial pode então ser chamada de adaptação locacional. Neste caso, decisões gerenciais afetam diretamente a localização da produção da firma, através da construção de uma nova planta ou a expansão ou fechamento das existentes" (id. ibid., p. 140 - tradução nossa).

De maneira geral, além da complexidade dos fatores que afetam a decisão do empresário, este tipo de enfoque baseado no comportamento da firma para explicar 
decisões de localização, é de difícil generalização, comprometendo a formalização de uma teoria normativa. Entretanto, se por um lado a dificuldade de se elaborar "leis gerais" de comportamento dificulta a formalização de teorias, por outro esta abordagem possibilita a realização de trabalhos empíricos ou estudos de casos, que, no âmbito da localização industrial, podem gerar resultados bastante interessantes para o poder público conhecer os padrões de localização de um dado setor e/ou as motivações dos empresários a escolher os sítios de estabelecimento da planta.

Deve-se, por isso mesmo, esclarecer que tal enfoque, especialmente aquele desenvolvido por Alan Pred, o primeiro questionar o caráter otimizador dos modelos clássicos de localização, foi logo submetido a severas críticas, tais como as de Harvey (1969), Thompson (1969) e Adams (1970), justamente por ser um enfoque vago e nada normativo.

Harvey (1969), por exemplo, ao examinar o trabalho de Alan Pred, concorda com a legitimidade das inúmeras inquietações e/ou dúvidas que surgiram na década de 60 a respeito das postulações dos chamados modelos clássicos de localização, como os de von Thünen, Weber, Lösch, Isard, e outros. Entretanto, o autor, ao lembrar uma valiosa regra na ciência que postula que "não se deve se desfazer de nenhuma teoria, não importa o quão inadequada seja, até que você tenha uma melhor para colocar no lugar", sugere ser muita pretensão das colocações comportamentalistas como solução para o dilema da localização industrial.

Apesar de as críticas destes três autores supracitados serem específicas ao trabalho de Alan Pred, não é extremo dizer que a última grande contribuição à teoria da localização deve-se a Walter Isard. Após sua obra, pouco ficou a ser empreendido nessa linha de análise, a não ser refinamentos, aplicações e aprofundamentos de aspectos tratados ou sugeridos por esse autor (Azzoni, 1982b).

Dessa forma, o enfoque comportamentalista da localização industrial deve ser encarado não como uma ferramenta alternativa aos modelos clássicos, mas sim aditiva.

Os complexos aves e suínos, bem como a atividade agroindustrial como um todo, apresentam fortes apelos para que se considerem as variáveis clássicas de 
localização, como custos de transportes (associados à disponibilidade de matériasprimas localizadas) e disponibilidade de mão-de-obra, entre outras, no estudo da escolha do local destinado à produção. No entanto, vê-se a necessidade de incorporar elementos que busquem nas motivações dos empresários (ou das firmas) as respostas para tal indagação.

Esclarece-se, finalmente, que o uso deste enfoque comportamentalista da localização industrial no estudo empírico da problemática da localização dos complexos de aves e suínos na região Centro-Oeste não tem a pretensão de criticar os modelos clássicos de localização. A escolha pela sua utilização adveio não somente dos objetivos almejados como também do método do estudo empírico a ser empregado.

No próximo capítulo, será exposta a proposta metodológica para alcançar os objetivos pretendidos deste estudo. 


\section{MATERIAL E MÉTODOS}

Neste capítulo serão evidenciados os aspectos metodológicos propostos para análise do problema locacional das empresas dos complexos aves e suínos na região Centro-Oeste. Buscando investigar da dinâmica locacional de tais empresas, pretende-se pesquisar empiricamente, através de questionário, o processo de decisão locacional, bem como os fatores chave na escolha do local produtivo.

Decidiu-se, assim, escolher como empresas representativas das agroindústrias avícola e suinícola, orientadoras das atividades produtivas de frangos e suínos, os abatedouros/frigoríficos estabelecidos na região Centro-Oeste. Destes abatedouros, alguns são integradores, ou seja, fazem parceria com granjeiros, e outros são independentes, sendo que ainda neste grupo podem se subdividir em estabelecimentos que apenas abatem e naqueles que produzem os animais (aves ou suínos) e posteriormente abatem. Na seqüência serão definidas as variáveis que fizeram parte dos questionários, em harmonia com o referencial teórico e com as pretensões deste estudo. No final deste capítulo, será exposta a técnica utilizada para o tratamento estatístico dos dados obtidos dos questionários.

\subsection{OBTENÇ̃̃o DOS DADOS}

Inicialmente procurou-se identificar todos os abatedouros/ frigoríficos de aves e suínos em operação no ano de 2000 nos estados de Goiás, Mato Grosso, Mato Grosso do Sul e Distrito Federal, para que se tivesse uma idéia da população total desta 
classe. O primeiro grupo de estabelecimentos a ser mensurado foram os sifados, ou seja, aqueles que têm registro no Serviço de Inspeção Federal (SIF). Estes dados foram obtidos junto à Secretaria de Defesa Agropecuária do Ministério da Agricultura e Abastecimento. Esta talvez tenha sido a relação de empresas mais facilmente obtida, uma vez que fazem parte de um registro federal, disponível na própria home page da Secretaria de Defesa Agropecuária.

Entretanto, sabia-se de antemão que os estabelecimentos não se limitavam aos sifados, havendo abatedouros/frigoríficos que têm inspeção estadual (SIE ou SISE), inspeção municipal (SIM), inspeção distrital (no caso do DF) ou ainda, clandestinos, estes últimos desconsiderados da população total. Para conseguir a relação destas empresas, recorreu-se às associações de avicultores e criadores de suínos de cada estado.

$\mathrm{O}$ acesso a estas informações foi um processo mais demorado pelo fato de, em alguns estados, não haver uma associação que centralize os dados sobre as atividades de suínos e/ou aves. Além disso, por se tratarem na grande maioria de empresas menores, os frigoríficos que têm apenas o registro estadual (SIE), apresentam uma dinâmica muito mais acelerada de abertura/fechamento de firmas, o que por vezes dificulta um levantamento oficial. Em outras palavras, em algumas entrevistas ou visitas, os representantes de associações declaravam que tal abatedouro estava requerendo SIE, outro está parado no momento, etc., informações que poderiam trazer alguma confusão para o fechamento do universo de empresas.

Como os abatedouros cadastrados no nível municipal (SIM) eram, segundo os técnicos consultados, desconhecidos até o momento ou de inexpressiva relevância, decidiu-se contemplar apenas os abatedouros que apresentavam registro no SIF ou no SIE (e também no sistema distrital).

Ademais, algumas empresas que apresentavam registro estadual (SIE) para abate de suínos eram, na verdade, casas de carnes, abatendo seus animais muitas vezes em terceiros. Outro fato também detectado apenas na pesquisa de campo, foi que alguns abatedouros especializados no abate de bovinos requereram no passado também o registro para o abate de suínos, mas sequer abatiam uma cabeça. Quando feita a consulta pela primeira vez no sistema da Secretaria de Defesa Agropecuária, detectara-se tais 
empresas como abatedoras de suínos, mas que na verdade apenas detinham o registro. Assim, estes dois últimos casos de empresas - as casas de carnes e os abatedouros que possuíam SIF tanto para abate de bovinos como de suínos, mas que apenas abatiam os primeiros - foram desconsiderados da população total.

Dessa forma, ao desconsiderar as empresas que não se enquadravam no contexto de abatedouros de aves e suínos, chegou-se ao número total de 46 estabelecimentos abatedouros/frigoríficos já em atividade na região Centro-Oeste ou que estavam iniciando projeto de instalação (Tabela 1).

Tabela 1. Número de estabelecimentos de abatedouros/frigoríficos na região Centro-Oeste, discriminado por estado, tipo de animal e tipo de Serviço de Inspeção

\begin{tabular}{lccccc}
\hline \multicolumn{1}{c}{ Estado } & \multicolumn{2}{c}{ Aves } & \multicolumn{2}{c}{ Suínos } & \multirow{2}{*}{ Total } \\
\hline Distrito Federal & 1 & - & 1 & 1 & 3 \\
Goiás & 6 & 9 & 1 & 7 & 23 \\
Mato Grosso & 3 & 1 & 3 & 2 & 9 \\
Mato Grosso do Sul & 4 & 1 & 3 & 3 & 11 \\
\hline \multicolumn{1}{c}{ Total } & 14 & 11 & 8 & 13 & 46 \\
\hline
\end{tabular}

Fonte: Dados da pesquisa de campo coletados em outubro de 2000

Levantados os estabelecimentos abatedouros/ frigoríficos com SIF ou SIE do Centro-Oeste, acredita-se ter contemplando o universo que representa as produções tecnificadas e comerciais de carne de frango e de suínos da região. Em virtude do número total de estabelecimentos, 46, ter sido plausível de se efetuar investigação através de questionários, considerou-se toda a população definida nesta pesquisa prévia.

Pelo exposto, fica definido que a fonte de dados destinada ao exame do problema proposto constou-se das respostas dos empresários aos questionários enviados. Registra-se que foi feito um esforço para contatar apenas pessoas que, ocupando cargos de decisão (gerentes ou proprietários), tenham efetivamente participado do processo de escolha locacional, conforme sugere Azzoni (1982b). Além disso, vale dizer que foi feito um contato prévio, via telefone, com cada investigado, para que o número de retorno dos questionários fosse maximizado. 
No entanto, para dar mais qualidade interpretativa aos dados obtidos, bem como conhecer in loco a realidade produtiva de aves e suínos em regiões de cerrado, foi feita uma pesquisa de campo de cerca de 15 dias. Nesta visita técnica, 10 das 46 empresas foram visitadas além das associações de aves e suínos eventualmente presentes em cada estado.

\subsection{DEFINIÇÃo DAS VARIÁVEIS}

Será apresentada a seguir a maneira com que as variáveis locacionais e de decisão foram tratadas no questionário. Assim, foram mantidos 3 (três) eixos principais de questões, quais sejam: características dos estabelecimentos, variáveis de decisão (representativas do processo de escolha) e variáveis locacionais. Optou-se por questões fechadas, geralmente de múltipla escolha, onde o indagado deverá escolher uma ou algumas alternativas dentro das possíveis. O questionário proposto pode ser visto no Anexo B, fazendo-se necessária, deste ponto em diante, a sua observação para melhor entendimento das variáveis.

\subsubsection{Características dos estabelecimentos}

A principal intenção em caracterizar aquilo que foi definido como o universo total dos abatedouros/frigoríficos de aves e suínos no Centro-Oeste é minimizar problemas relativos a generalizações. Tratar indiscriminadamente o conjunto dessas empresas pode ocultar particularidades importantes.

Baseando-se nas divisões realizadas em trabalhos empíricos, como o de Azzoni (1982b) e o de Moore, Tyler e Elliott (1991), foram investigados grupos de características das empresas, buscando identificar em que medida firmas com características diferentes apresentaram procedimentos distintos. São eles: 
a) Tamanho da firma - indagado no cabeçalho do questionário, no Anexo B, o tamanho da firma foi obtido através da proxy da capacidade de abate do estabelecimento, em termos de número de animais abatidos por dia. A pressuposição a priori, é que empresas maiores foram mais cuidadosas no seu processo de escolha locacional, podendo ainda diferir quanto à ênfase dada a variáveis tidas como secundárias para definir o local de instalação da planta de abate. Esta variável teve o nome de tamanho;

b) Status da empresa - corresponde à primeira pergunta do questionário, objetivando identificar se a empresa constitui-se num novo negócio (ou seja, não existia antes), ou se é uma expansão de uma empresa regional, ou se é uma expansão de uma empresa cuja origem não é o Centro-Oeste, ou se é uma relocalização dentro da região Centro-Oeste ou se é uma relocalização de outra região para o Centro-Oeste. A intenção desta pergunta foi captar se o estabelecimento é oriundo de uma reorientação estratégica para o Centro-Oeste ou somente um negócio local. Este exame será completado com a próxima questão. Esta variável recebeu o nome de status;

c) Origem do negócio - pretendeu-se com esta pergunta identificar de onde se originou o negócio, ou seja, saber se o(s) proprietário(s) é(são) oriundo(s) do local, ou oriundo(s) de qualquer estado da região Centro-Oeste ou migrou(aram) de outras regiões para o Centro-Oeste. Esta variável teve o nome de origem;

d) Estrutura produtiva da empresa - objetivou averiguar se as empresas realizam ou mantêm contratos de integração com avicultores ou criadores de suínos. Este tipo de segregação em empresas independentes (divididas nas que abatem o que produzem ou nas que compram animais no mercado) e integradoras, foi de extrema importância para as pretensões deste estudo, pois se acreditava que estes dois grupos diferir-se-iam entre si em aspectos organizacionais, estratégicos, além de competirem muitas vezes por mercados distintos. Com relação às integrações, era esperado que tivessem particular atenção a aspectos relacionados com a mão-deobra, bem como observância de outros grupos do mesmo setor presentes na região, 
visto que são empresas, na sua grande maioria, que disputam mercados maiores que as empresas independentes. Esta variável recebeu o nome de estrutura;

e) Abastecimento de milho - parte 1 - esta questão, bem como seu complemento, deveria apenas ter sido respondida pelos estabelecimentos que compram milho para auto-suprimento ou para seus integrados; ou seja, as empresas que realizam integração vertical com produtores de frango/suíno ou as que abatem o que produzem. Assim, pediu-se que a pessoa respondesse qual a percentagem do milho é comprada localmente, de cidades vizinhas dentro do estado, de outros estados dentro da região Centro-Oeste e de outras regiões exceto a região Centro-Oeste, fazendo com que a soma dos quatro campos resultasse em 100\%. O principal intuito desta pergunta foi identificar o grau de proximidade à produção de milho. Esta variável teve o nome de abastecimento;

f) Abastecimento de milho - parte 2 - Interessada em saber qual a importância e a satisfação com relação aos níveis de preços pagos pelo milho nas regiões em que as empresas estão estabelecidas, esta pergunta pretendeu provar ou não se as empresas atribuíam à época da pesquisa (segundo semestre de 2000) grande peso ao milho nos custos e nas decisões. Esta variável teve o nome de importância;

g) Meta do empresário - esta questão pretendeu captar qual era a principal pretensão do empresário ao decidir-se que abriria um novo negócio, montaria uma filial, ou relocalizaria a sua unidade. Para isso, as opções apresentadas foram: acompanhar a tendência da nova geografia do setor, minimizar custo de abastecimento de milho, buscar novos mercados ou apenas iniciar uma atividade produtiva como outra qualquer. Esta variável teve o nome de meta;

h) Finalidade da produção - procurou-se identificar com esta questão para onde o estabelecimento destina suas vendas. Assim, pediu-se que fosse preenchida a lacuna com o percentual de vendas de cada nível, fazendo com que a soma dos quatro campos resulte em 100\%. Foram definidos os níveis mercado local (ou seja, o estado), mercado regional (ou seja, a região Centro-Oeste), mercado nacional exceto a região Centro-Oeste e mercado externo. Esta variável teve o nome de finalidade; 


\subsubsection{Variáveis de decisão}

Estas variáveis tiveram o intuito de tentar retratar o processo de escolha locacional entre as empresas pesquisadas. Os resultados oriundos deste tipo de questionamento serão de particular importância para o poder público ou organismos envolvidos com o desenvolvimento regional na reorientação/atração de investimentos ligados às cadeias de aves e suínos, assim como outros setores do agronegócio, cujas motivações devem não diferir substancialmente das motivações dos empresários destes setores investigados.

O foco desta análise foi dirigido para a compreensão de como os empresários muniram-se de informações relevantes para chegarem mais próximos possíveis daquilo que buscavam. Para tanto, foram definidas 6 (seis) variáveis, explanadas a seguir:

a) Amplitude da análise - buscando captar quão ampla foram as considerações sobre as possíveis alternativas locacionais, foi elaborada a questão 7 (presente no questionário no Anexo B). Procurou-se com esta questão tentar identificar se as empresas já manifestavam pretensões tácitas de se localizar na região Centro-Oeste ou a instalação da planta produtiva na região foi apenas consequência de um estudo que levou a esta decisão. Assim, perguntou-se se, ao adotar alternativas durante o processo de escolha do sítio produtivo, a empresa considerou apenas regiões dentro do estado, se considerou apenas regiões dentro do Centro-Oeste, se considerou regiões brasileiras indistintamente ou se não considerou alternativas. Esta variável recebeu o nome de amplitude;

b) Duração do processo de escolha - buscou-se com esta questão checar se as decisões locacionais foram resultado de estudos precipitados ou se empresas realizaram trabalhos mais cuidadosos antes de decidir o sítio locacional. Evidentemente não existe uma correlação positiva e definida entre tempo de análise e êxito na localização. Uma análise comedida e minuciosa de nada implica em sucesso. Podese deparar com um empresário que se deixou mobilizar tão somente por seu intuito ou vontade própria, cuja análise não levou tempo algum, ser mais bem sucedido que 
uma grande empresa que realizou um estudo locacional de mais de um ano. Entretanto, acredita-se que, via de regra, estudos mais demorados, geralmente realizados por empresas de maior porte, tendem a chegar mais próximos daquilo que buscavam. Para o questionário, foram definidos os seguintes intervalos de tempo do processo de escolha: de 1 a 5 meses, de 6 a 12 meses e acima de 12 meses. Houve ainda a opção não estudou a localização. Esta variável teve o nome de duração;

c) Informações utilizadas na análise do local definitivo - pretendeu-se, com esta indagação, verificar quais foram as informações que a empresa levou em consideração para escolher definitivamente o local onde estabeleceria seu abatedouro/frigorífico. Foram oferecidas alternativas desde as mais simples, como visita ao local, visita a associações agropecuárias, até as mais elaboradas, como utilização de consultor externo. Estas opções tentaram mostrar o nível de cuidado do empresário quanto à definição do local a estabelecer-se. Esta variável recebeu o nome de informações;

d) Comparações monetárias - Esta questão teve a intenção de identificar se as empresas realizaram algum tipo de comparação monetária dos preços das matérias-primas básicas, dos custos da mão-de-obra, do preço da terra, ou dos custos dos transportes de produtos e de matérias-primas entre as alternativas tidas como viáveis de estabelecimento. À semelhança da variável anterior, que procurou investigar a preocupação dos empresários, as comparações monetárias possivelmente mostrariam se a empresa preocupou-se em constatar de antemão se haveria economias significativas vis-a-vis outras alternativas ou antigos sítios produtivos, em virtude da localização naquela região. Esta variável teve o nome de comparações;

e) Opção pela última alternativa - a idéia que envolveu esta pergunta é a de que, se a escolha foi a última alternativa cronologicamente falando, indica que o empresário sentiu-se satisfeito com as condições oferecidas pelo local e não precisou averiguar nenhuma outra região. Gerariam-se, assim, indícios de que um comportamento voltado para a satisfação de certos quesitos é preferido a um otimizador, conforme discutido no capítulo 3.2. Um comportamento mais próximo de alguém que otimiza, seria não optar pela última alternativa, mas sim, escolher a melhor entre um grupo 
delas. Esta variável teve o nome de opção, apresentando ainda a alternativa $a$ empresa não estudou alternativas;

f) Elaboração pela empresa do perfil da localização procurada - esta variável pretendeu captar se, antes mesmo de iniciar-se o processo de tomada de decisão, a empresa havia elaborado um perfil do local que almejava estabelecer-se. Esta variável foi dicotômica, do tipo sim/não e recebeu o nome de perfil. Caso a resposta fosse positiva, houve uma complementação para saber se o perfil foi alterado durante o processo de escolha, com as seguintes escolhas: não mudou, mudou parcialmente ou mudou totalmente. Espera-se que as empresas que haviam desenhado de antemão um perfil contendo as características da localização que buscavam apresentariam maior convicção em sua decisão por este ou aquele sítio. Ou seja, estas empresas teriam maior dificuldade de ser envolvidas por outros fatores que as afastassem do ótimo que buscavam;

A definição deste grupo de variáveis contou com uma certa dose de subjetividade do autor, inspirada ainda no trabalho de Azzoni (1982b) que procurou retratar o processo de escolha de indústrias no estado de São Paulo no início da década de 80 .

Espera-se, com estas variáveis decisórias, estar encontrando indicativos de como as empresas dos agronegócios de aves e suínos desenvolveram o seu processo de escolha locacional. Estes aspectos captados pelas variáveis decisórias foram, posteriormente, desagregados de acordo com as características das empresas (definidas pelas variáveis de características) buscando identificar certos padrões de comportamento.

\subsubsection{Variáveis locacionais}

As variáveis locacionais foram elaboradas baseando-se nos vetores locacionais elucidados no item 2.3 deste trabalho. Além desses vetores, definidos como relevantes para a atividade produtiva de frangos e suínos, foram abordados também 
aspectos complementares relacionados à influência de forças na localização agroindustrial.

As variáveis de influência na localização estão discriminadas na questão 13 do questionário no Anexo B. De acordo com a metodologia que Azzoni (1982b) utilizou para graduar cada fator, será também usada a seguinte escala, crescente em importância, qual seja: nula, pequena, grande, foi um dos fatores decisivos ou foi o fator individualmente causador da escolha.

Assim, os diversos aspectos investigados puderam ser agrupados dentro das seguintes variáveis locacionais:

a) Fatores relacionados às matérias-primas básicas (milho e farelo de soja)

* Proximidade às principais fontes/lavouras de milho;

* Nível de custo do milho;

* Proximidade às principais fontes de farelo de soja;

* Nível de custo do farelo de soja;

b) Fatores relacionados à mão-de-obra

* Nível dos custos salariais;

* Qualidade da mão-de-obra;

* Disponibilidade de mão-de-obra;

c) Fatores relacionados à infra-estrutura

* Disponibilidade de serviços (assistências técnicas, centros de pesquisa, recursos humanos, etc.);

* Qualidade da infra-estrutura;

d) Fatores relacionados às políticas específicas de desenvolvimento regional ${ }^{28}$

* Programa(s) de desenvolvimento regional;

e) Fatores relacionados à concessão de incentivos fiscais

* Incentivos fiscais estaduais;

* Incentivos fiscais municipais;

f) Fatores relacionados às questões do ambiente

\footnotetext{
${ }^{28} \mathrm{O}$ fator desenvolvimento regional foi complementado pela questão 15 (no Anexo B).
} 
Problemas de expansão em outras regiões;

* Problemas ambientais (relacionados aos dejetos) em regiões de forte concentração da atividade;

* Boas condições para futuras expansões/atratividade do ambiente;

g) Outros fatores

Proximidade aos mercados consumidores;

* Preferência individual do empresário;

* Vínculo familiar na região;

Uma outra pergunta foi idealizada para completar as questões sobre a infra-estrutura de onde a empresa está localizada, pedindo que notas sejam dadas a vários aspectos a ela relacionados.

Finalmente comenta-se que se tomou o cuidado de que todas as perguntas que envolvessem algum tipo de categorização das empresas (como a pergunta 1) fossem do tipo exaustivas e mutuamente exclusivas em função da metodologia envolver a construção prévia de tabelas de contingência (mais detalhes sobre esta técnica serão abordados no próximo item). Ou seja, uma classificação é exaustiva, explica Everitt (1992), quando ela fornece suficientes categorias para acomodar todos os membros da população. As categorias são mutuamente exclusivas quando cada membro da população pode ser corretamente alocado a uma, e somente uma, categoria.

\subsection{ANÁLISE dOS DADOS}

As variáveis definidas no questionário, no Anexo $\mathrm{B}$, são do tipo qualitativas, envolvendo apenas uma resposta dicotômica do tipo sim/não e as demais, categóricas (do tipo, nula, pequena, grande, etc.). Dessa forma, a população pôde ser classificada em diferentes categorias e, ao se contar o número de indivíduos (empresas) em cada categoria, foram obtidas freqüências. Essa contagem ou freqüência, representa justamente o tipo de dados que a pesquisa está envolvida: dados qualitativos ao invés de 
quantitativos obtidos da medição de variáveis contínuas, como produtividade, produção, renda, custos, etc. (Everitt, 1992).

Assim, a análise descritiva dos dados requer técnicas de análises multivariadas. Dentro deste grupo de análises, há a análise de tabelas de contingência de dois sentidos (para apenas 2 variáveis) ou de múltiplos sentidos (para mais de 2 variáveis). Também para número de variáveis maior do que 2 e que se baseiam também em dados não-métricos (qualitativos), haveria a possibilidade de se usar modelo loglinear ou análise de correspondência.

Em virtude de ser possível analisar o processo de decisão locacional bem como os fatores influentes na escolha do local produtivo através de pares de variáveis, percebeu-se, no exame das tabelas de contingência, seja através de teste estatístico ou de modo descritivo, a melhor opção perante as proposições deste trabalho.

\subsubsection{Análise de tabelas de contingência ${ }^{29}$}

As tabelas de contingência, que relacionam variáveis duas a duas conforme o interesse do cruzamento, constituíram-se na base do delineamento dos testes de hipótese bem como das interpretações através de estatística descritiva. Na sua forma geral e mais simples, a tabela de contingência bi-dimensional pode ser vista na Tabela 2 , na qual uma amostra de $\boldsymbol{N}$ observações é classificada com relação a duas variáveis qualitativas ( $\boldsymbol{L}$ e $\boldsymbol{C}$ ), uma tendo $\boldsymbol{I}$ categorias (ou modalidades) e a outra $\boldsymbol{J}$ categorias.

Nessas tabelas, pôde-se cruzar as diversas características relevantes das

empresas pesquisadas com diversas variáveis decisórias e variáveis locacionais (conforme definidas anteriormente), tomadas duas a duas (1 característica com uma variável decisória, e assim por diante).

\footnotetext{
${ }^{29}$ Este tópico foi baseado em Everitt (1992).
} 
Tabela 2. Forma geral de uma tabela de contingência de duas dimensões

\begin{tabular}{|c|c|c|c|c|c|c|c|}
\hline \multirow{2}{*}{$\begin{array}{c}\text { Variável L } \\
\text { (categorias) }\end{array}$} & \multicolumn{6}{|c|}{ Variável C (categorias) } & \multirow{2}{*}{ Total } \\
\hline & 1 & 2 & $\ldots$ & $j$ & $\ldots$ & $J$ & \\
\hline 1 & $n_{11}$ & $n_{12}$ & $\ldots$ & $n_{1 j}$ & $\cdots$ & $n_{1 J}$ & $n_{1}$ \\
\hline 2 & $n_{21}$ & $n_{22}$ & $\ldots$ & $n_{2 j}$ & ... & $n_{2 J}$ & $n_{2}$ \\
\hline$\cdots$ & $\cdots$ & $\cdots$ & $\cdots$ & $\cdots$ & $\cdots$ & $\cdots$ & $\cdots$ \\
\hline$I$ & $n_{i 1}$ & $n_{i 2}$ & $\ldots$ & $n_{i j}$ & .. & $n_{i J}$ & $n_{i}$ \\
\hline$\cdots$ & $\cdots$ & $\cdots$ & $\cdots$ & $\cdots$ & $\cdots$ & $\cdots$ & $\cdots$ \\
\hline$I$ & $n_{I 1}$ & $n_{I 2}$ & $\ldots$ & $n_{I j}$ & $\ldots$ & $n_{I J}$ & $n_{I .}$ \\
\hline Total & $n_{.1}$ & $n_{.2}$ & $\ldots$ & $n_{j}$ & $\ldots$ & $n_{. J}$ & $n . .=N$ \\
\hline
\end{tabular}

Fonte: modificado de Everitt (1992)

Nesta tabela, cada uma das células $\left(n_{11}, n_{12}, n_{i j}\right.$, etc.) representa a freqüência ou a contagem de indivíduos em cada um dos cruzamentos. Por exemplo, a célula $n_{12}$ representa o número de indivíduos da amostra que estão contidos na categoria 1 da variável $\boldsymbol{L}$ e ao mesmo tempo na categoria 2 da variável $\boldsymbol{C}$. O número total de observações da $i$-ésima categoria da variável $\boldsymbol{L}$ é denotado de $n_{i}$. e o total de observações da $j$-ésima categoria da variável $\boldsymbol{C}$ é denotado de $n_{\cdot j}$, elementos conhecidos também como totais marginais ou perfis linha e perfis coluna, respectivamente. Por último, o elemento $n_{. .}$representa o número total de observações na amostra e é também marcado como $N$ (Everitt, 1992). Assim, tem-se:

$$
\begin{aligned}
& n_{i .}=n_{i 1}+n_{i 2}+\Lambda+n_{i J}=\sum_{j=1}^{J} n_{i j} \\
& n_{. j}=n_{1 j}+n_{2 j}+\Lambda+n_{I j}=\sum_{i=1}^{I} n_{i j} \\
& n_{. .}=N=\sum_{i=1}^{I} \sum_{j=1}^{J} n_{i j}=\sum_{i=1}^{I} n_{i .}=\sum_{j=1}^{J} n_{. j}
\end{aligned}
$$

Partindo-se desta tabela, as contagens podem ser transformadas em freqüências relativas, bastando dividir cada célula por $n$.., como mostra a eq. (4).

$$
f_{i j}=\frac{n_{i j}}{n_{. .}}
$$

onde: 
$f_{i j}$ : freqüência relativa à contagem total da $i$-ésima categoria da variável $\boldsymbol{L}$ que apresenta a categoria $j$ da variável $\boldsymbol{C}$.

Vale salientar que, mesmo após esta divisão, os dados eram originalmente freqüências ou contagens e não medições de variáveis contínuas. Mesmo as medições de variáveis tidas como contínuas (como por exemplo o abate de animais por dia, proxy do tamanho da firma), podem ser transformadas em discretas ao utilizar-se intervalos com escalas contínuas.

\subsubsection{Independência e associação entre as variáveis}

Talvez o maior interesse de tabular dados em tabelas de contingência seja a detecção de associação entre as variáveis. Ou seja, quer se saber se as diferenças observadas entre as proporções das categorias de uma variável são significativas o suficiente para serem atribuídas a outros fatores que não aleatórios. Esses fatores seriam, então, associados à outra variável relacionada na tabelada de contingência.

Este tipo de teste, o de associação entre duas variáveis, é de especial interesse para o relacionamento de características das empresas, como tamanho, origem do negócio, estrutura da empresa, com variáveis de decisão. O intuito é, por exemplo, identificar se empresas maiores, ou que são integradas verticalmente às granjas, ou cuja origem não é a região Centro-Oeste tiveram maior cuidado e estudo na escolha do local definitivo da atividade.

Voltando à tabela de contingência exposta na Tabela 2, tem-se que a probabilidade de uma observação pertencer à $i$-ésima categoria da variável disposta em linha e à j-ésima categoria da variável disposta em coluna é $\mathrm{p}_{\mathrm{ij}}$. Dessa forma, a freqüência esperada na $i j$-ésima célula deve ser dada por:

$$
F_{i j}=N p_{i j}
$$

Admitindo que $p_{i}$. representa a probabilidade de uma observação 
pertencer à $i$-ésima categoria da variável linha e que $p_{. j}$ representa a probabilidade de uma observação pertencer à $j$-ésima categoria da variável coluna, $p_{\mathrm{ij}}$ pode ser reescrito da seguinte forma, considerando a lei de multiplicação de probabilidades:

$$
p_{i j}=p_{i .} p_{. j}
$$

Substituindo (6) em (5), obtém-se:

$$
F_{i j}=N p_{i .} p_{. j}
$$

Apesar de parecer pouco convincente que um estimator de probabilidade seja obtido de proporções da própria tabela de contingência, Mood e Greybill $(1963)^{30}$, citados por Everitt (1992) mostram que os melhores estimadores $\hat{p}_{i .}$ e $\hat{p}_{. j}$ das probabilidades $p_{i .}$ e $p_{. j}$ são baseados justamente nos totais marginais dos valores observados:

$$
\hat{p}_{i .}=\frac{n_{i .}}{N} \mathrm{e} \hat{p}_{. j}=\frac{n_{. j}}{N}
$$

A partir destes estimadores dados na eq. (8) pode-se estimar a freqüência esperada na célula $i j$ da tabela:

$$
E_{i j}=N \hat{p}_{i .} \hat{p}_{. j}=N \frac{n_{i .}}{N} \frac{n_{\cdot j}}{N}=\frac{n_{i \cdot} n_{. j}}{N}
$$

Dessa maneira, para que as duas variáveis sejam designadas como

\footnotetext{
${ }^{30}$ MOOD, A.M.; GREYBILL F. A. Introducing to the theory of statistics. New York: MacGraw-Hill, 1963.

${ }^{31}$ Estes estimadores são ainda de máxima verossimilhança.
} 
independentes, as freqüências estimadas através da equação (9) e as freqüências observadas não devem diferenciar-se significativamente. Para verificar se o tamanho das diferenças entre as freqüências observadas e as freqüências esperadas é significativo o suficiente para detectar associação entre variáveis, testes estatísticos devem ser usados. Dentre eles, o qui-quadrado apresenta vantagens de sua utilização.

\subsubsection{Teste qui-quadrado}

Um teste baseado na medição do tamanho das diferenças entre os valores esperados e observados foi pela primeira vez proposto por Pearson $(1904)^{32}$, citado em Everitt (1992), justamente para testar a independência entre as variáveis, sendo postulado sob a seguinte hipótese de nulidade $\left(\mathrm{H}_{0}\right)$ :

$$
H_{0}: p_{i j}=p_{i .} p_{. j}\left(=E_{i j}\right)
$$

Este teste, usando a estatística $\chi^{2}$, é dado por:

$$
\chi^{2}=\sum_{i=1}^{l} \sum_{j=1}^{c} \frac{\left(n_{i j}-E_{i j}\right)^{2}}{E_{i j}}
$$

O método usado para decidir se o teste $\chi^{2}$ é significativo ou não (ou seja, se é possível ou não rejeitar a hipótese de nulidade, $\mathrm{H}_{0}$ ) é baseado na distribuição de probabilidade para $\chi^{2}$ sob a pressuposição de que a hipótese nula é verdadeira ${ }^{33}$. Dessa forma, quando a estatística $\chi^{2}$ calculada for maior do que o valor tabulado para um determinado nível de significância, $\mathrm{H}_{0}$ pode ser rejeitada. Caso contrário, a hipótese nula não pode ser rejeitada.

A única informação necessária que ainda falta ser definida para decidir

\footnotetext{
32 PEARSON, K. On the theory of contingency and its relation to association and normal correlation. London: Drapers’ Co. Memoirs, Biometric Series n. 1, 1904.

${ }^{33}$ Assumindo que as freqüências observadas têm uma distribuição multinomial, pode-se considerar que a estatística $\chi^{2}$ tem uma distribuição próxima a distribuição qui-quadradro.
} 
quando o valor de $\chi^{2}$ obtido de alguma tabela de contingência leva a uma rejeição ou não da hipótese nula, é o número de graus de liberdade, assim definido:

$$
\gamma=(l-1)(c-1)
$$

onde:

$l$ - número de categorias da variável $L$ dispostas na linha da tabela de contingência;

$c$ - número de categorias da variável $C$ dispostas na coluna da tabela de contingência.

\subsubsection{Correção de continuidade de Yates e teste exato de Fischer}

Ao se derivar a estatística $\chi^{2}$ visando o teste de hipótese, na verdade o que se está fazendo é empregar uma distribuição de probabilidade contínua, chamada distribuição qui-quadrado, como uma aproximação de uma distribuição de probabilidades discretas, chamada multinomial. Yates $(1934)^{34}$, citado por Everitt (1992), sugere uma correção que consiste na subtração de 0,5 das discrepâncias (observado - esperado) positivas e na adição de 0,5 às discrepâncias negativas. $O$ valor de $\chi^{2}$, nomeado agora como valor qui-quadrado corrigido para continuidade, fica da seguinte maneira:

$$
\chi^{2}=\sum_{i=1}^{l} \sum_{j=1}^{c} \frac{\left(\left|n_{i j}-E_{i j}\right|-0,5\right)^{2}}{E_{i j}}
$$

Um problema que pode surgir da derivação da distribuição qui-quadrado como uma aproximação da estatística $\chi^{2}$ ocorre quando as freqüências esperadas são pequenas. Quando isso acontece, a aproximação perde qualidade. Em virtude do número total de empresas ser relativamente pequeno, 27, havia no início a preocupação com tal entrave. A saída para este tipo de impasse seria a utilização do teste exato de Fischer como alternativa do teste qui-quadrado.

\footnotetext{
${ }^{34}$ YATES, F. Contingency tables involving small numbers and the chi-square test. J. Roy. Statist. Soc. Suppl., v.1, p.217-235, 1934.
} 
No entanto, é o próprio Everitt (1992) que comprova que para amostras reduzidas, o teste qui-quadrado com as correções de continuidade anteriormente descritas, proporciona um valor de probabilidade ( $p$ value) bastante similar ao obtido com o teste exato de Fisher.

Além disso, essa última alternativa fornecida por Everitt (1992) para amostras reduzidas foi ratificada com êxito no trabalho de Brum (2000) que utilizou semelhante metodologia para tratar dados de 40 empresas dispostos em tabelas de contingência.

\subsubsection{Exemplo de tabela de contingência e procedimentos do teste qui-quadrado}

Neste trabalho, as tabelas de contingência tiveram tamanhos variados, desde $3 \times 2$ até $4 \times 4$. Um exemplo de uma tabela $3 \times 4$ seria o cruzamento entre a característica tamanho e a variável de decisão locacional duração do estudo, ilustrada na Tabela 3 .

Tabela 3. Exemplo de tabela de contingência a ser construída neste estudo

\begin{tabular}{|c|c|c|c|c|c|}
\hline \multirow{2}{*}{ Tamanho } & \multicolumn{4}{|c|}{ Duração do estudo } & \multirow{2}{*}{ Total } \\
\hline & Não & $0-5$ meses & 6-11 meses & Mais do que 12 & \\
\hline Pequena & $n_{11}$ & $n_{12}$ & $n_{13}$ & $n_{14}$ & $n_{1}$ \\
\hline Média & $n_{21}$ & $n_{22}$ & $n_{23}$ & $n_{24}$ & $n_{2}$ \\
\hline Grande & $n_{31}$ & $n_{32}$ & $n_{33}$ & $n_{34}$ & $n_{3}$ \\
\hline Total & $n_{.1}$ & $n_{.2}$ & $n_{.3}$ & $n_{.4}$ & $n_{. .}=N$ \\
\hline
\end{tabular}

Fonte: Elaboração do autor baseada em Everitt (1992)

Neste exemplo, de acordo com (12), tem-se 6 graus de liberdade. Através da tabela qui-quadrado, os seguintes valores críticos seriam obtidos para os respectivos níveis de significância ${ }^{35}$ do teste: teste a $1 \%$ de significância, valor crítico de 16,812 e teste a 5\% de significância, valor crítico de 12,592.

O procedimento para rejeição ou não da hipótese de nulidade seria comparar o valor obtido em (13) com o valor crítico padrão da tabela qui-quadrado ao

\footnotetext{
${ }^{35}$ Denomina-se nível de significância $(\alpha)$ à probabilidade de se cometer um erro tipo I em testes de hipótese. Segundo Hoffman (1991), o erro tipo I consiste em rejeitar $\mathrm{H}_{0}$ dado que $\mathrm{H}_{0}$ é verdadeira.
} 
nível de significância desejado. Caso o valor obtido exceda o crítico, o teste é tido como significativo, podendo-se rejeitar a hipótese nula (hipótese de independência entre as variáveis relacionadas na tabela de contingência) e, portanto, admitir a existência de dependência entre as variáveis. Se o valor calculado não exceder o valor crítico, não se rejeita $\mathrm{H}_{0}$, caracterizando variáveis que não apresentam dependência entre si.

Finalmente, comenta-se que para o exame dos fatores determinantes da escolha do local (basicamente a questão 13 do questionário no Anexo B), foi usada apenas estatística descritiva, a partir dos cruzamentos dos fatores com as principais características das empresas. 


\section{RESULTADOS E DISCUSSÃO}

A taxa de retorno dos questionário foi de aproximadamente $59 \%$, sendo que das 27 empresas que responderam (veja a Tabela 4 que pormenoriza as origens das respostas), 7 já haviam preenchido questionário na pesquisa feita em campo. As demais empresas foram abordadas através de ligação prévia e posterior envio de um fax.

Tabela 4. Número total de empresas pesquisadas e número de questionários respondidos, discriminados por estado, tipo de abate e inspeção

\begin{tabular}{lccccc}
\hline \multicolumn{1}{c}{ Estado } & \multicolumn{2}{c}{ Aves } & \multicolumn{2}{c}{ Suínos } & \multirow{2}{*}{ Total } \\
\hline Distrito Federal & SIF & SIE & SIF & SIE & \\
Goiás & $1(1)$ & - & $1(0)$ & $1(1)$ & $3(2)$ \\
Mato Grosso & $6(3)$ & $9(6)$ & $1(1)$ & $7(0)$ & $23(10)$ \\
Mato Grosso do Sul & $3(3)$ & $1(1)$ & $3(3)$ & $2(0)$ & $9(7)$ \\
\hline \multicolumn{1}{c}{ Total } & $4(2)$ & $1(1)$ & $3(3)$ & $3(2)$ & $11(8)$ \\
\hline
\end{tabular}

Fonte: Dados da pesquisa de campo

Valores entre parênteses representam o $\mathrm{n}^{\circ}$ de empresas que retornaram o questionário

Dentre os principais entraves para a maximização do número de respostas poderiam ser destacados a lacuna entre o nível intelectual do questionário e o nível de instrução do empresário, além de uma certa desconfiança de se passar informações da empresa. Apesar de bastante claro e direto, para algumas pessoas, principalmente pequenos abatedores de aves e suínos, ficou evidente que a complexidade ficou acima das capacidades. Além disso, o grande envolvimento de proprietários de pequenos negócios com toda a administração da empresa e o grau de atribulação de alguns diretores de grupos maiores impediu que estes dispendessem tempo para responder um questionário de pesquisa acadêmica. 
Todavia, o número de empresas que se trabalhou foi adequado para fins de testes de hipótese em tabelas de contingência, desde que utilizada a correção de Yates, descrita no item 3.3.1.3.

Nos próximos tópicos serão expostas as principais características das empresas pesquisadas, bem como os cruzamentos entre elas. Na parte subseqüente, serão apresentados os resultados dos testes de hipótese das variáveis locacionais cruzadas com as características, elucidando o estudo do processo decisório da firma. Por último, serão discutidos os fatores que influenciaram na escolha do local produtivo.

Antes, porém, serão feitos esclarecimentos da proporcionalidade obtida entre o universo total de empresas e as respondentes, bem como ressalvas a respeito da interpretação dos resultados em função do método empregado na pesquisa.

\subsection{ESCLARECIMENTOS INICIAIS}

\subsubsection{A questão da proporcionalidade universo de empresas versus respondentes}

Após a coleta de dados através da pesquisa de campo bem como do envio dos questionários, sentiu-se a necessidade de conhecer minimamente as empresas que não retornaram as respostas. Esse esforço foi devido a uma preocupação com relação à proporcionalidade baseada em algum critério, mesmo sabendo que diferenças seriam inevitáveis.

Pode-se dizer que este tipo de problema de não proporcionalidade já era admissível basicamente por dois motivos. Primeiro porque, pela falta de quaisquer informações prévias sobre as empresas, não foi possível proceder a uma triagem. E, em segundo porque, mesmo que se elegesse uma amostra das empresas que mantivesse a proporção de algum critério (como por exemplo, tamanho), não se salvaguardaria a resposta de todas utilizando-se questionário. 
Na Tabela 5 estão expostas as três variáveis de características escolhidas para representarem a proporcionalidade entre o universo total que foi considerado e as empresas respondentes.

Tabela 5. Proporcionalidade entre o universo total das empresas e as respondentes, com relação a características selecionadas

\begin{tabular}{|c|c|c|c|c|}
\hline \multirow{2}{*}{ Variável } & \multirow{2}{*}{ Categoria } & \multicolumn{2}{|c|}{ Abrangência das respostas (\%) } & \multirow{2}{*}{ Desvio* (a)-(b) } \\
\hline & & Todas as empresas (a) & Empresas respondentes (b) & \\
\hline \multirow{4}{*}{ Instalação } & até 80 & 13,0 & 11,1 & 1,9 \\
\hline & $81-90$ & 17,4 & 14,8 & 2,6 \\
\hline & $91-95$ & 37,0 & 40,7 & $-3,8$ \\
\hline & $96-00$ & 32,6 & 33,3 & $-0,7$ \\
\hline \multirow{3}{*}{ Tamanho } & pequena & 41,3 & 29,6 & 11,7 \\
\hline & média & 28,3 & 29,6 & $-1,4$ \\
\hline & grande & 30,4 & 40,7 & $-10,3$ \\
\hline \multirow{3}{*}{ Estrutura } & independente & 13,0 & 11,1 & 1,9 \\
\hline & integrada & 52,2 & 66,7 & $-14,5$ \\
\hline & comercial & 34,8 & 22,2 & 12,6 \\
\hline
\end{tabular}

Fonte: Dados da pesquisa

*desvio calculado em pontos percentuais

\subsubsection{Problemas intrínsecos à pesquisa via questionários}

É imprescindível ressaltar algumas distorções que podem ter havido nas respostas dos questionados em função do próprio método de pesquisa conduzido bem como do estilo das questões veiculadas.

Os dois problemas chave seriam a subjetividade do respondente e o componente tempo.

O primeiro é significativo nas perguntas que envolvem algum tipo de graduação, como por exemplo importância pequena, média, grande, ou decisiva. Muitas vezes, a percepção dos limites entre um nível e outro não é a mesma entre os entrevistados. 
O segundo problema adveio do fato de que as empresas estavam, via de regra, resgatando fatos do passado ao preencher o questionário. Umas mais (20 ou 30 anos), outras menos (meses). A precisão das respostas poderia ter ficado comprometida pelo grande espaço de tempo em que tais decisões foram tomadas.

Ficaria, então, a dúvida se o empresário, no momento em que respondia ao questionário, lembrava-se exatamente se, por exemplo, a proximidade aos mercados consumidores teria sido um fator nulo, pequeno, grande ou decisivo na escolha do local definitivo da localização.

\subsection{CARACTERÍSTICAS DAS EMPRESAS}

\subsection{1 Época de instalação}

Após o grande movimento de avanço da agricultura sobre as regiões de cerrado na década de 70, o desenvolvimento agroindustrial tomou corpo a partir de 85, principalmente com a expansão de grandes empresas nacionais que abriram filiais no Centro-Oeste.

Com relação aos abatedouros de aves e suínos pesquisados, 11\% instalaram-se até 1980, 15\% entre 1981 e 1990, 41\% entre 1991 e 1995 e 33\% entre 1996 e 2000 (Figura 8).

Entretanto, quando se cruza o número de empresas com a capacidade de abate, percebe-se que 91\% das empresas grandes instalaram-se na década de 90 (a definição de tamanho da empresa será elucidada no próximo item), conforme indica a Tabela 4A no Anexo A.

Levando-se em conta o status da empresa, nota-se também na Tabela 4A que $100 \%$ das empresas que responderam que o negócio está relacionado a uma 
expansão de uma empresa cuja origem não é o Centro-Oeste (categoria exp. CO da tabela) deu-se na década de 90.

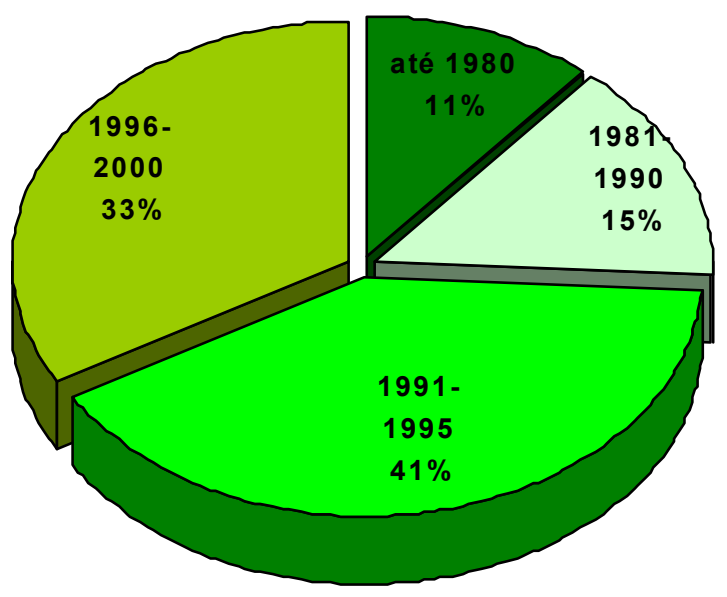

Fonte: Dados da pesquisa

Figura 8 - Classificação das empresas de acordo com a época de instalação do negócios

\subsubsection{Tamanho das Empresas}

Para determinar o tamanho das empresas usou-se como proxy o número de animais abatidos por dia, sem dúvida a variável que traz a melhor representação desta característica. O critério para divisão adotado foi baseado na classificação da Secretaria de Defesa Agropecuária do Ministério da Agricultura e Abastecimento, fazendo-se os ajustes pertinentes para a estratificação em apenas três categorias - pequena, média e grande -, cujos limites estão definidos na Tabela 6.

Tabela 6. Critérios para a classificação do tamanho das empresas

\begin{tabular}{lcc}
\hline \multicolumn{1}{c}{ Classificação } & \multicolumn{2}{c}{ Tipo de abate (animais/dia) } \\
& Aves & Suínos \\
\hline Pequena & até 9.600 & até 80 \\
Média & de 9.600 a 48.000 & de 80 a 400 \\
Grande & mais que 48.000 & mais que 400 \\
\hline $\begin{array}{l}\text { Fonte: adaptado da classificação da Secretaria de Defesa Agropecuária do } \\
\text { Ministério da Agricultura e Abastecimento }\end{array}$
\end{tabular}


Na Figura 9 está exposta a divisão dos abatedouros por tamanho.

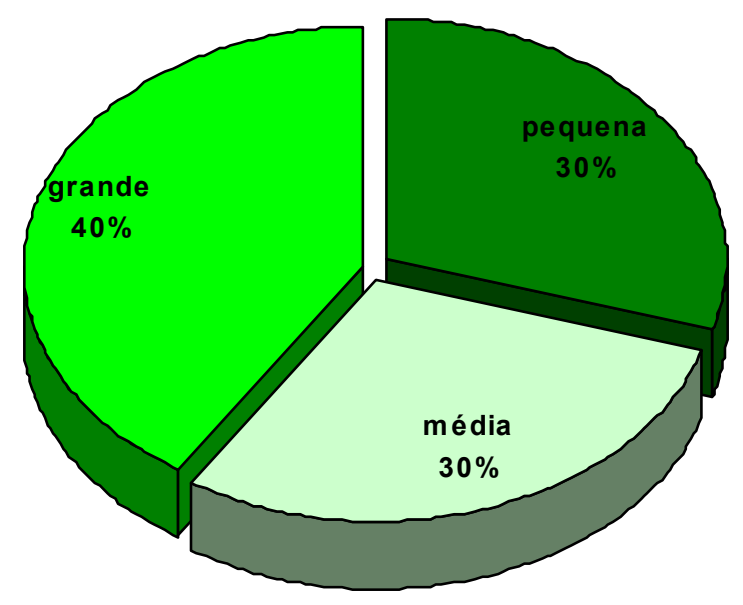

Fonte: Dados da pesquisa

Figura 9 - Classificação das empresas por tamanho, usando-se como proxy o número de animais abatidos por dia

Procedendo-se ao cruzamento da característica tamanho com as demais características (Tabela 13 no Anexo A), é interessante observar que cerca de $91 \%$ das empresas grandes são integradoras e 9\% são abatedouros comerciais; isto é, compram animais no mercado, abatem, frigorificam e vendem (estrutura produtiva encontrada apenas nos abatedouros de suínos). Pode-se dizer que este resultado já era esperado pelo fato de o modelo de integração vertical necessitar de uma escala mínima de abate para valer a pena o esforço da coordenação.

Entretanto, o que chama a atenção é a elevada percentagem de empresas que fazem integração na categoria pequena: 62,5\% das empresas pequenas são integradoras, $25 \%$ independentes e $12,5 \%$ abatem comercialmente. A princípio, esperava-se uma maior concentração das empresas pequenas na categoria independente da variável estrutura. Uma provável explicação para isso, detectada na pesquisa de campo, é que algumas empresas pequenas originaram-se de granjas parceiras de algum projeto de integração, que, ao ganharem escala, resolveram tocar o seu próprio negócio sobre os moldes da integração vertical. 
Fazendo-se comparações com a origem do negócio, com relação às empresas pequenas, 62,5\% apresentam proprietários oriundos do local, 12,5\% oriundos de outro estado da região Centro-Oeste e $25 \%$ oriundos de outra região que não a Centro-Oeste. Já as empresas médias e grandes tiverem o percentual oriundos de outra região que não a Centro-Oeste ao redor de $63 \%$ cada.

Importante ainda é observar como estão distribuídas as distintas metas iniciais das empresas com relação ao tamanho das firmas. Os resultados mais interessantes apontam que $75 \%$ das empresas pequenas tinham como meta inicial apenas iniciar uma atividade produtiva como outra qualquer; as empresas médias ficaram mais concentradas nas opções busca por novos mercados (37,5\%) e apenas iniciar uma atividade produtiva como outra qualquer (37,5\%); já as grandes, quase $73 \%$ tinha como meta essencial do projeto minimizar custos de abastecimento de milho.

\subsubsection{Status e origem do negócio}

Muito se tem falado sobre um movimento migratório de empresas do segmento grãos-carnes para as regiões de fronteira, sobretudo para o Centro-Oeste, motivadas basicamente pela busca de matérias-primas - leia-se milho - mais baratas. Sobre esta questão, a pergunta que objetivou conhecer de onde está surgindo a produção de aves e suínos no Centro-Oeste mostrou que não houve processo migratório, seja ele oriundo da própria região ou vindouro de outras regiões, sobretudo do Sul do país (observar na Figura 10 que nenhuma empresa escolheu as alternativas que contemplavam o processo migratório, relocalização dentro do Centro-Oeste e relocalização de qualquer outra região do país para o Centro-Oeste). 


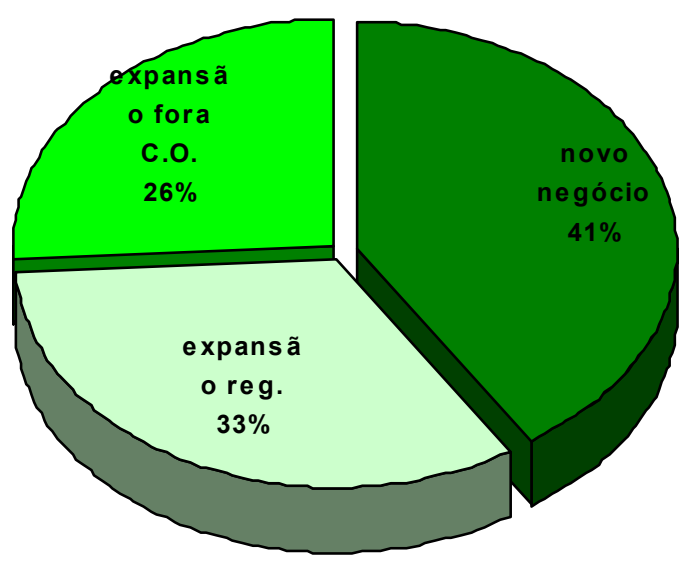

Fonte: Dados da pesquisa

Figura 10 - Classificação das empresas de acordo com o status do negócio

O trabalho de Helfand e Rezende (1998) já sinalizava que para se registrar uma migração da produção de aves e suínos do Sul para o Centro-Oeste, o estoque de animais bem como a produção teriam que estar sinalizando queda no Sul visa-a-vis aumento no Centro-Oeste, o que não aconteceu até 1995. Na verdade, segundo os autores, ambas regiões aumentaram os estoques de aves e suínos (principalmente MS e MT), não havendo, assim, evidências de um êxodo da produção do Sul para o CentroOeste.

Pelo resultado desta questão, observa-se que a maior parte dos negócios, $64 \%$, foi relativo a empresas que se constituem de um novo negócio ou expansão regional, ficando, a princípio, a idéia que teria sido um movimento prioritariamente endógeno à região Centro-Oeste. Entretanto, ao cruzar esta variável com a variável origem, nota-se que, das empresas que se constituem de um novo negócio, 45\% apresentam empresários oriundos de regiões fora do Centro-Oeste. Além disso, das que se constituem de uma expansão regional, 33\% também tiveram empresários originários de regiões externas ao Centro-Oeste.

Fica evidente não só a importância de analisar estas duas variáveis de modo casado como também o caráter migratório não de empresas mas sim de empresários. 
Outro dado importante é que das empresas que são uma expansão oriunda de outras regiões exceto o Centro-Oeste, 100\% são grandes (com relação à variável tamanho) e 100\% são integradoras (com relação à variável estrutura) (veja Tabela 13 no Anexo A), confirmando justamente a pressuposição de expansão dos grandes grupos de aves e suínos para as regiões de fronteira.

Salienta-se ainda que o resultado desta variável (status) traz implicações mais para frente, pois como não houve empresas que optaram pelas categorias 4 e 5 da pergunta 1 do questionário no Anexo $\mathrm{B}$, chegar-se-ia em totais marginais iguais a zero $\left(n_{i .}\right)$, o que inviabilizaria a utilização de teste qui-quadrado para as tabelas de contingência.

Assim, optou-se em simplesmente excluir estas duas categorias da variável status. Mesmo não sendo uma técnica recomendada por Everitt (1992), explicase que este é um caso muito particular, pelo fato de a variável ser do tipo exaustiva e mutuamente exclusiva. Ou seja, em apenas uma das categorias a firma se enquadra, não havendo a possibilidade de ela necessitar de uma categoria extra do tipo n.d.a. Dessa forma, se por acaso o questionário tivesse sido veiculado sem as duas últimas categorias, o resultado seria absolutamente o mesmo. Isso só não foi feito justamente por preocupações quanto à exaustividade.

Analisando apenas a classificação das empresas quanto à origem do negócio, percebe-se, na Figura 11 que, salvo um pequeno percentual para os proprietários que caracterizavam-se como oriundos de outros estados dentro do próprio Centro-Oeste (4\%), ou a origem é local (praticamente retratando o nível de cidade) ou é externa à região. Apenas esta informação indica que não tem havido por parte dos empresários locais busca por locais considerados melhores. Ou seja, dificilmente um empresário que deseje expandir ou iniciar um novo negócio, o fará fora de seu estado. 


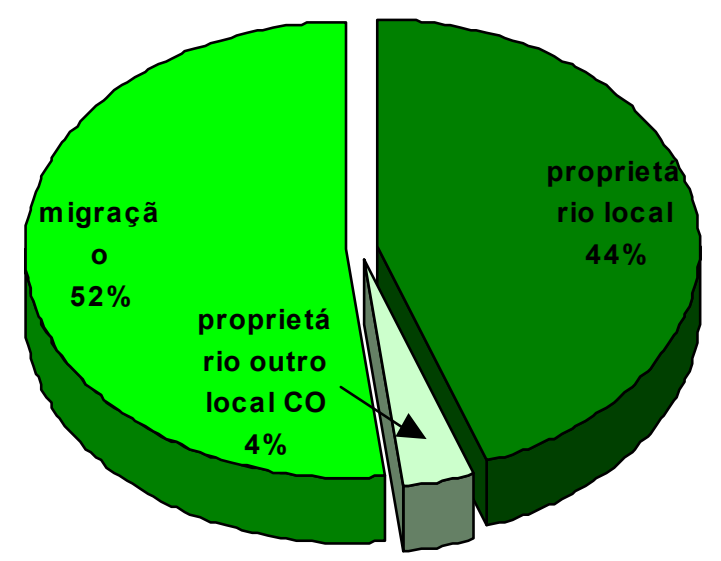

Fonte: Dados da pesquisa

Figura 11 - Classificação das empresas consultadas de acordo com a origem do(s) empresário(s)

Do total das empresas que afirmaram que os empresários vinham de uma migração de estados fora da região Centro-Oeste, $50 \%$ são de origem sulina e $50 \%$ oriundos da região sudeste, quase todos de São Paulo. Assim, poderia ser dito que dos empresários migrantes, $100 \%$ vieram do eixo produtivo Sul-Sudeste.

\subsubsection{Estrutura produtiva das empresas}

De acordo com a Figura 12a, pode-se observar que a grande maioria das empresas, 67\%, tem como estrutura produtiva o modelo de integração vertical. Entretanto, quando se pondera a estrutura produtiva com a capacidade de abate das empresas, vê-se que a concentração da produção propriamente dita de aves e suínos no Centro-Oeste está nas integrações (Figura 12 b). Ou seja, 83\% da capacidade de abate de aves e suínos está concentrada nas integrações.

Mesmo não atingindo o limite da integração vertical que poderia ser baseado no Sul do país, onde praticamente $100 \%$ da produção de aves e quase $100 \%$ da de suínos é integrada, os estados do Centro-Oeste já demonstram maturidade em relação ao modelo sulino de produção intensiva. Mesmo porque foi justamente o "know how" 
das empresas que se expandiram ou dos empresários que migraram do Sul que trouxeram à região esta estrutura produtiva.

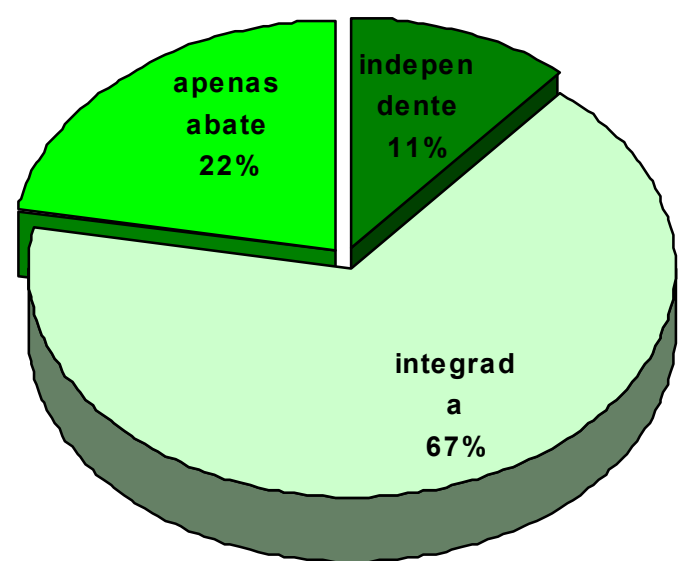

(a)

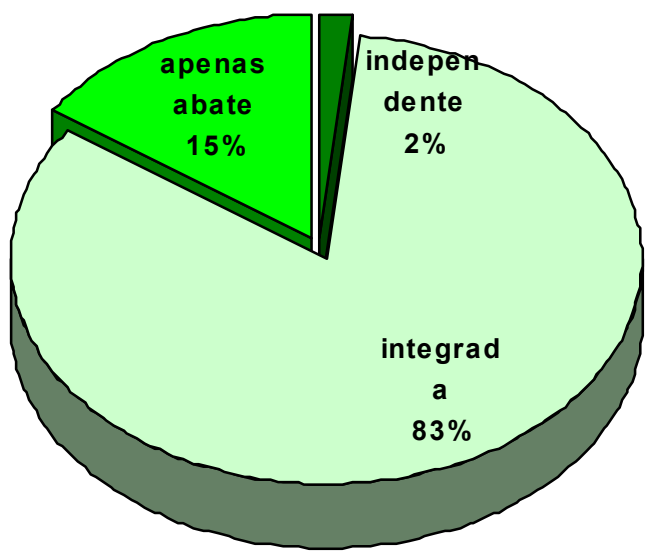

(b)

Fonte: Dados da pesquisa

Figura 12 - Classificação das empresas segundo a estrutura produtiva, de acordo com o número de empresas (a) e com a capacidade de abate (b)

\subsubsection{Meta do empresário}

Buscando identificar se existia uma pretensão tácita por parte das empresas de se localizarem no Centro-Oeste, por motivos ligados a variáveis tradicionais ou não, a pergunta 5 no questionário no Anexo $\mathrm{B}$ tem o seu resultado ilustrado na Figura 13. 


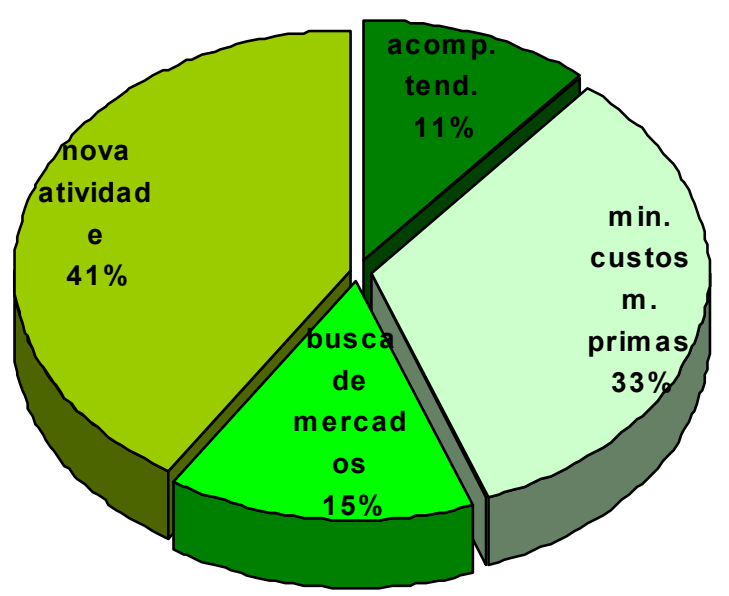

Fonte: Dados de pesquisa

Figura 13 - Classificação das empresas consultadas de acordo com a meta do(s) empresário(s)

Salienta-se o significativo percentual, 41\%, de empresas que disseram apenas iniciar uma atividade como outra qualquer. Em outras palavras, não buscavam nada de especial no Centro-Oeste. Mais da metade destas empresas são pequenas, 36,4\% delas constituíam-se num novo negócio e 63,6\% numa expansão dentro do Centro-Oeste (veja Tabela 13 no Anexo A).

Já dos 33\% que tinham na minimização dos custos de abastecimento de milho a sua principal meta de produzir no Centro-Oeste, $100 \%$ instalaram-se ao longo da década de 90, 88,9\% constituem-se de empresas grandes e quase $90 \%$ eram representados por empresas que são integradoras.

A década de 90 foi a que marcou o maior dinamismo do milho nos cerrados. Não somente com os ganhos de área e rendimento da safra de verão mas principalmente com o grande crescimento do milho safrinha na região Centro-Oeste (Figura 14). Com o rápido crescimento da oferta, os preços consolidaram-se em patamares bastante inferiores aos da região Sudeste, principalmente (veja mais a frente na Figura 17 que ao longo da segunda metade da década de 90, os preços do milho posto em São Paulo foram cerca de 32\% superiores aos preços praticados no mercado atacadista de Rio Verde-GO). 


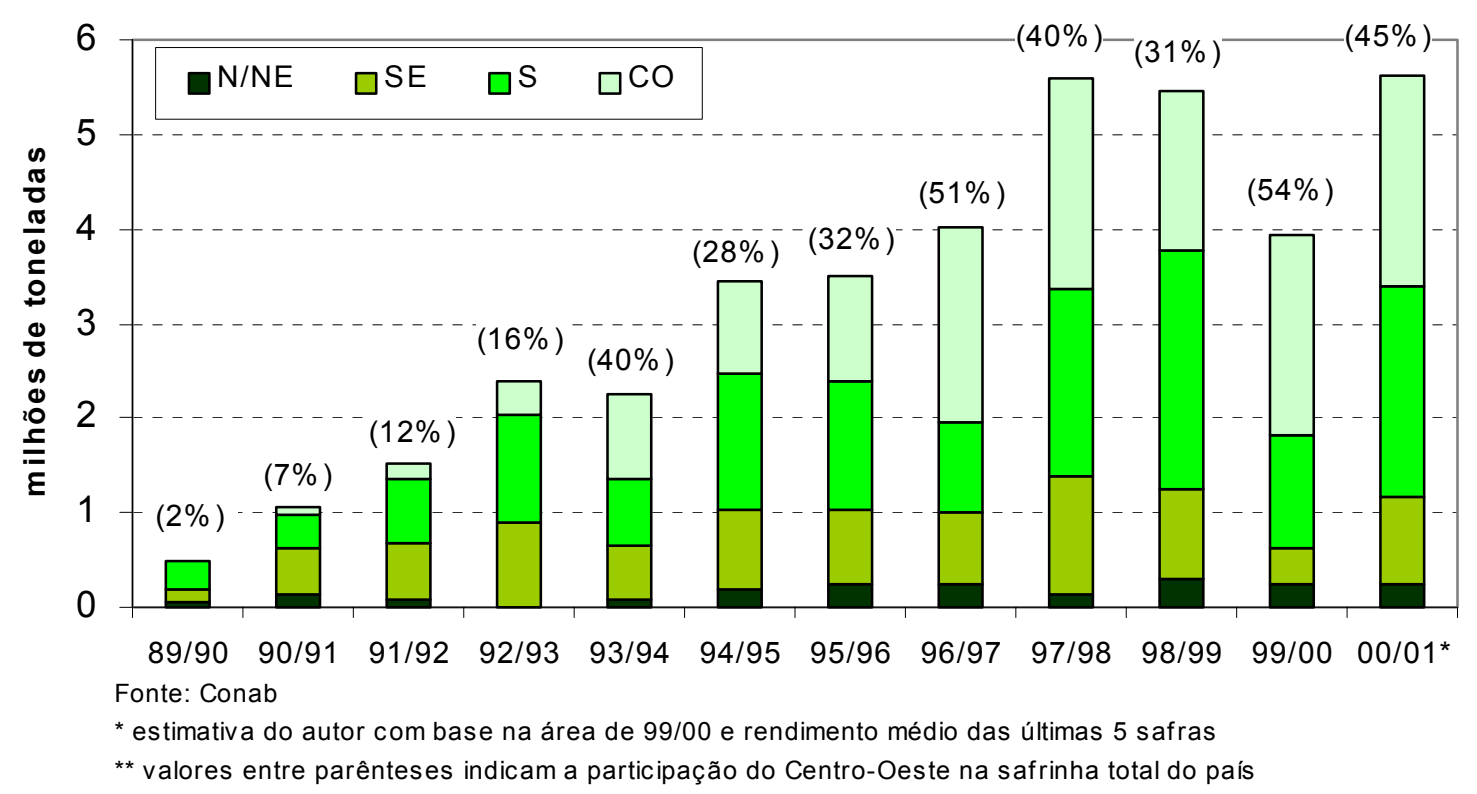

Figura 14 - Evolução da produção de milho safrinha (segunda safra) por região do país, de 89/00 a 00/01

Este seria sem dúvida um grande atrativo às agroindústrias ligadas à produção de aves e suínos, especialmente no início década de 90 quando o excedente de milho ficou mais evidente na região Centro-Oeste. Isto ajuda a explicar o porquê de todas as empresas que buscavam minimizar custos se estabeleceram ao longo da década de 90 .

A questão 4 no Anexo B, por sua vez, procurou retratar um pouco melhor o que representa o milho como matéria-prima essencial na engorda de aves e suínos, sendo oportuna sua interpretação neste ponto da discussão dos resultados. A primeira parte da pergunta buscou identificar o quão próximas são as compras de milho para os abatedouros. Das 21 empresas que compram milho para seu consumo ou para o consumo de seus integrados, $86 \%$ compram mais de $3 / 4$ das necessidades anuais de milho no local ou nas cidades vizinhas. Apenas 14\% das empresas apresentaram um mix mais complexo de compras onde seria incluído um percentual de outros estados. Importante, no entanto, salientar que nenhuma destas empresas compram milho em estados fora da região Centro-Oeste ou se abastecem diretamente de ração comercial. 
A confirmação de que o milho é um produto de tranqüila aquisição advém da segunda parte da questão 4, que mostrou que para 64\% das empresas que compram milho é pequena a dificuldade na aquisição. Nenhuma empresa manifestou dificuldade grande na aquisição de milho.

A fim de obter uma visão geral da disposição espacial dos abatedouros/frigoríficos com relação à produção de milho (na média anual do período de 95-99), foi elaborada a Figura 15 que pontua geograficamente as 46 empresas de acordo com o tamanho (pequena, média ou grande) e com a atividade (aves ou suínos), colocadas sobre o mapa de produção de milho no Centro-Oeste estratificado em 5 níveis.

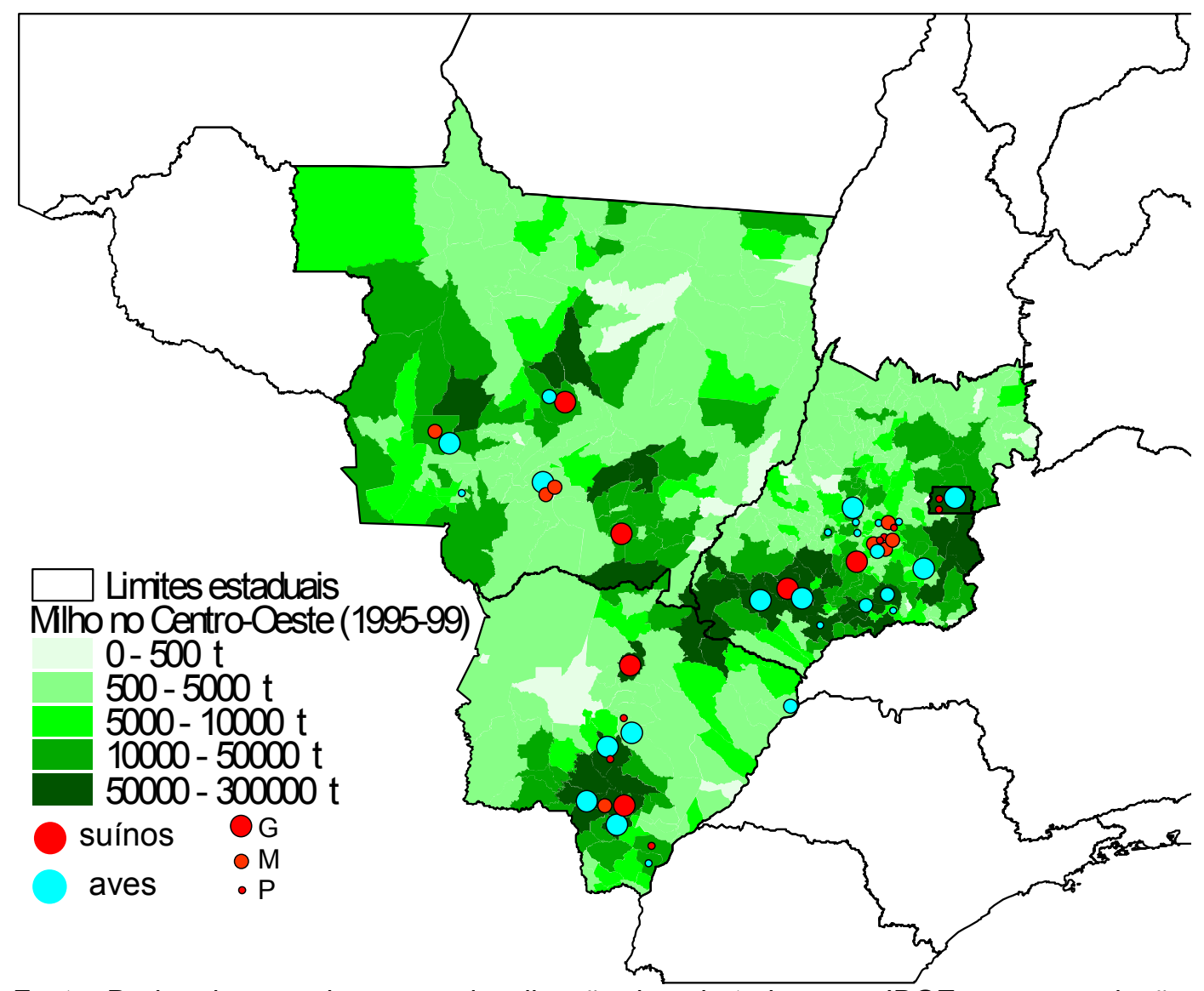

Fonte: Dados da pesquisa para a localização dos abatedouros e IBGE para a produção municipal de milho

Figura 15 - Mapa de localização de todos os abatedouros de aves e suínos considerados na pesquisa dispostos sobre a distribuição espacial da produção média anual de milho na região Centro-Oeste, no período de 95 a 99 
Nota-se na Figura 15 que a localização dos abatedouros de aves e suínos coincide com os principais pólos produtivos de milho nos estados da região CentroOeste, especialmente em Goiás e Mato Grosso do Sul.

Esta coincidência, em alguns casos, esteve fincada não somente ao tipo de colonização regional como também à própria dinâmica agrícola dos mais importantes pólos produtivos de soja que começaram a produzir excedentes de milho, dada uma necessidade agronômica.

Em algumas regiões, a agregação de valor ao milho sob a forma de criação animal surgiu como uma opção para um problema de excedente produtivo. Exemplos desta realidade seriam as regiões de Nova Mutum (MT) e São Gabriel d'Oeste (MS), cidades localizadas em regiões setentrionais dentro dos respectivos estados e que apresentam como ponto comum a colonização sulina.

Nestes casos, na virada da década de 80 para a 90, um surto de nematóide do cisto da soja praticamente obrigou os produtores a rotacionar a leguminosa com uma gramínea no inverno. O milho foi a cultura que melhor casou com a soja de verão e o seu cultivo no Centro-Oeste como um todo teve um forte impulso. Porém, pelo fato de serem regiões distantes dos principais centros de consumo, os preços do milho eram baixíssimos para compensar o frete. A saída foi buscar um destino para o milho localmente. Quando lideres pesquisaram o que produzir para aproveitar o excedente da produção local, a suinocultura despontou como favorita, uma vez que vários traziam a experiência do sul do país. Em suma, a origem da produção de carnes nestas regiões adveio tão somente a uma necessidade de aproveitamento do excedente de milho da região, constatação possível somente com a pesquisa de campo, reveladora de particularidades não captadas no método de pesquisa conduzido.

A segunda parte da quarta pergunta do questionário indagou qual o nível de satisfação com os patamares de preços pagos pelo milho na região. Apenas cerca de $10 \%$ das empresas que compram milho disseram estar muito satisfeitas (satisfação grande) com os preços do milho. Já o restante $90 \%$ declarou nível de satisfação pequeno ou médio. 
O resultado desta parte da questão 4B sobre a satisfação com relação aos níveis de preços pagos na região não surpreende pois a pesquisa foi realizada em um momento onde um mercado altista de milho havia sido recente. Um déficit no abastecimento interno causou grande procura da região Sudeste pelo milho do CentroOeste, fazendo-o sustentar em elevado patamar de preço (Figura 16). Na verdade, os anos agrícolas de 98/99 e 99/00 foram marcados por consecutivas insuficiências produtivas que deram suporte a um mercado altista em todas as praças de comercialização do país.

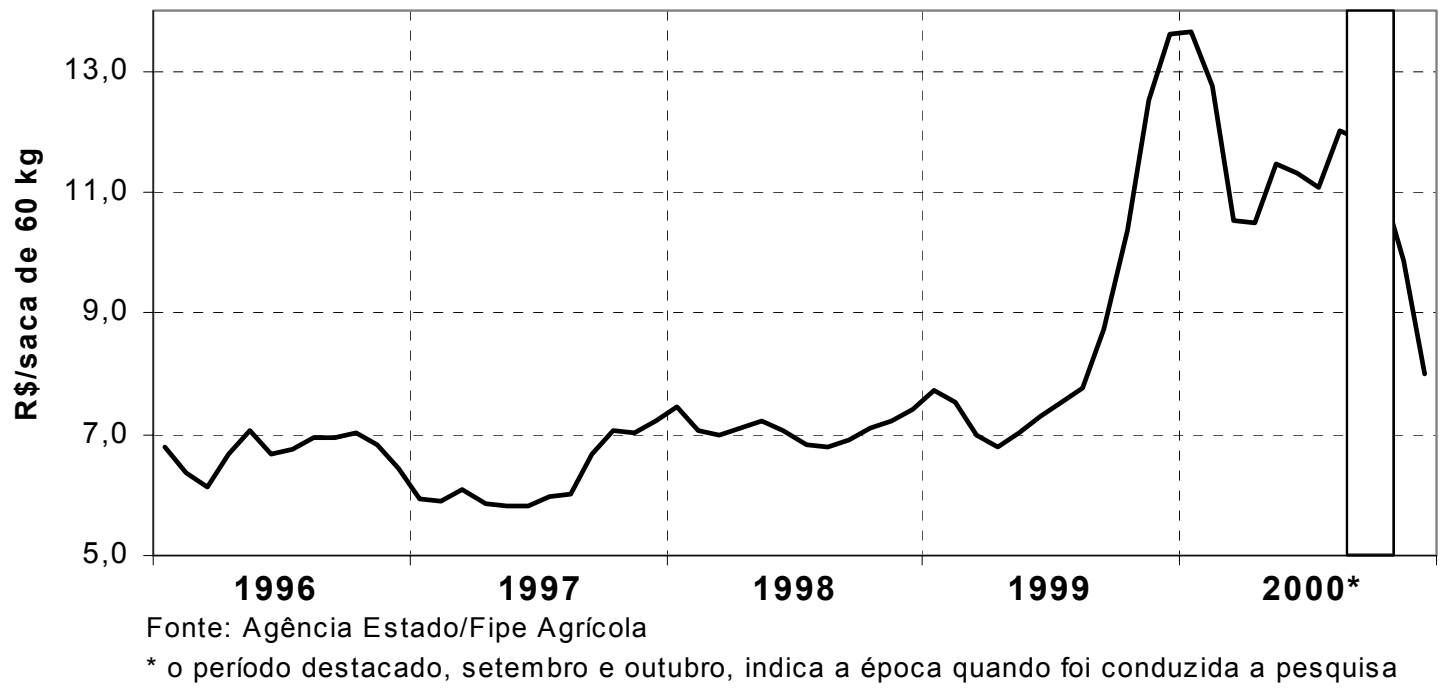

Figura 16 - Evolução dos preços médios mensais do milho na praça de Rio Verde$\mathrm{GO}$

Vale ressaltar também que não somente os preços absolutos vinham em ascendência desde o início de 99 no Centro-Oeste (Figura 16, que apresenta os preços médios mensais do milho da região representados pela praça de Rio Verde-GO), como os preços relativos do milho goiano, por exemplo, passaram a valer mais em relação ao milho no mercado atacadista de São Paulo (posto São Paulo) e do Oeste paranaense (Cascavel), como mostra a Figura 17. 


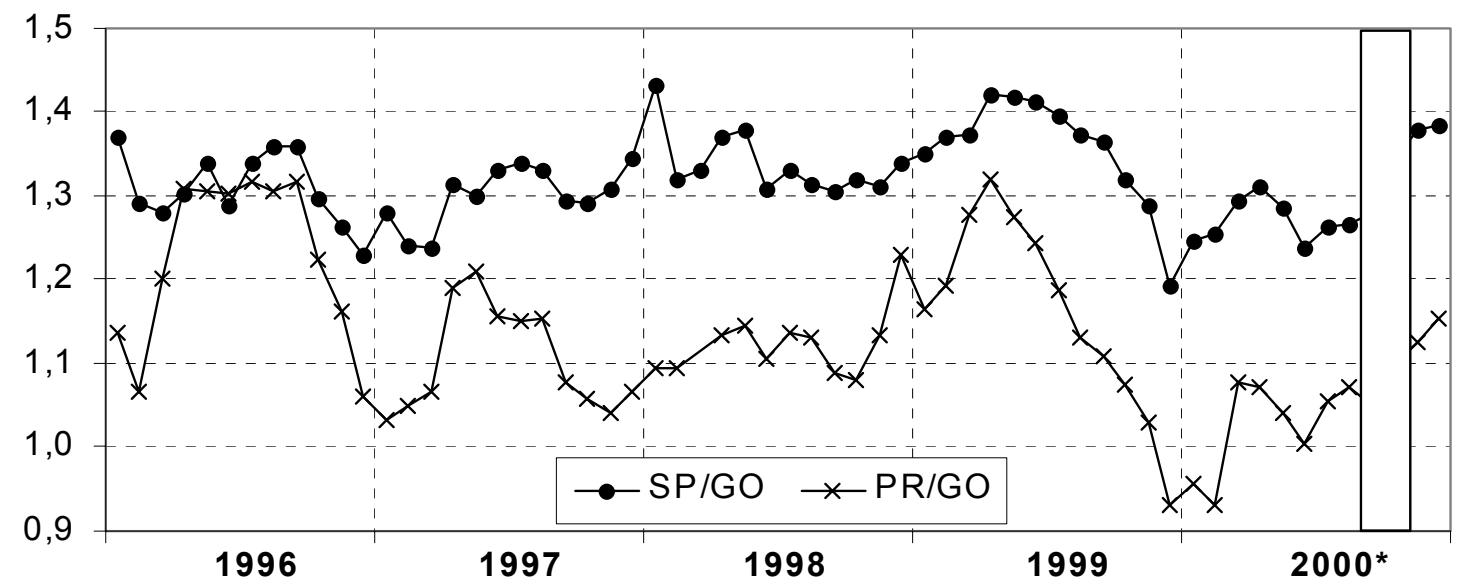

Fonte: Agência Estado/Fipe Agrícola

* o período destacado, setembro e outubro, indica a época quando foi conduzida a pesquisa

Figura 17 - Evolução dos preços relativos médios mensais do milho cotado em Rio Verde-GO com relação às praças "posto São Paulo" e "Cascavel-PR" de 1996 a 2000

Entretanto, este parece ter sido um movimento casuísta, fruto apenas de um desequilíbrio temporal e geográfico da oferta de milho no Brasil. Ao analisar na Figura 17 os preços relativos do milho do Centro-Oeste com relação a São Paulo e Paraná ao longo da segunda metade da década de 90, nota-se que não houve aumento dos preços relativos do milho no Centro-Oeste.

Assim, apesar de ter sido constatado em 99/00 um significativo consumo de milho dentro da região Centro-Oeste ${ }^{36}$, de acordo com estimativas da ConAB, os preços relativos nestas praças superavitárias ainda se mantêm inferiores aos níveis de preços praticados em importantes pólos consumidores como São Paulo.

\footnotetext{
${ }^{36}$ Das 6,43 milhões de toneladas produzidas nos estados da região Centro-Oeste, $45 \%$ foi consumido dentro da própria região na safra 99/00, segundo estimativas obtidas junto à CONAB.
} 


\subsection{O PROCESSO DE DECISÃO LOCACIONAL}

Se se considerar tanto a complexidade como a esporadicidade das decisões locacionais, já salientadas no Referencial Teórico bem como a interferência de fatores pessoais dos tomadores de decisão, verifica-se que o processo de escolha do sítio produtivo é peculiar de cada empresa.

Mesmo sendo bastante particular de cada empresa, as seguintes hipóteses para fins de condução dos testes de independência entre as variáveis foram estabelecidas antes da pesquisa ser conduzida:

* Espera-se que empresas grandes, ou aquelas que são uma expansão de outras regiões que não o Centro-Oeste (todas do Sul-Sudeste, como foi verificado no item anterior) ou as que são integradas verticalmente com os granjeiros, tivessem maior cuidado na escolha do local produtivo. As justificativas para este raciocínio baseiam-se na idéia de que empresas grandes necessitam fazer análises mais precisas porque imobilizam mais recursos. Além disso, empresas de grande porte acabam tendo as condições (financeiras e técnicas) para realizarem uma pesquisa muito bem elaborada. Esta seria uma hipótese mais global, cujo indicador de intensidade de estudo será uma nova variável, obtida da conjugação das variáveis de 7 a 12, detalhada no item 4.3.1.7.

* No mesmo raciocínio que a primeira hipótese, espera-se que empresas maiores tenham maior amplitude de análise, não se limitando apenas a regiões específicas, determinadas a priori por alguma pretensão particular da empresa. Assim, acreditase que a variável amplitude não seja independente das variáveis tamanho e estrutura.

* Acredita-se que as empresas maiores ou integradoras dispendam maior tempo para estudar a localização. Assim, espera-se que a variável duração não seja independente das variáveis tamanho e estrutura.

* Espera-se que as empresas maiores ou integradoras não tenham como escolha a última alternativa a ser pesquisada. Estariam elas mais próximas de um comportamento otimizador do que satisfação de requisitos mínimos. Dessa forma, 
espera-se que a variável última não seja independente das variáveis tamanho e estrutura $^{37}$.

Espera-se ainda que, as variáveis de decisão locacional (das questões de 7 a 12 e aquela que conjugará todas) tenham dependência com a característica meta do empresário, principalmente pelo fato de empresas que tinham como meta principal a minimização dos custos de abastecimento de milho diferenciarem-se sobremaneira daquelas que apenas estavam iniciando uma atividade produtiva como outra qualquer.

Neste capítulo, em que será feita a apresentação e análise de como as empresas chegaram à escolha do local produtivo, primeiramente serão mostrados os resultados das respostas obtidas nas perguntas de 7 a 12 do questionário no Anexo B, cruzando-se cada variável de decisão com as principais variáveis de característica.

Após esta apresentação, os resultados dos testes de hipótese, que justamente testarão a independência dos cruzamentos de cada variável de característica com as variáveis de decisão, serão analisados.

\subsubsection{Interpretação das variáveis de decisão}

Na Tabela 14 no Anexo A estão apresentados os resultados das variáveis de decisão locacional, cruzadas uma a uma com as características, tamanho, status, estrutura e meta. Explica-se que a característica origem não foi utilizada para analisar as variáveis locacionais pelo fato de haver uma linha marginal de freqüência muito baixa (1), o que traria problemas para os testes de hipótese.

\subsubsection{Amplitude da análise}

Os resultados das respostas das empresas respondentes, presentes na Tabela 14 no Anexo A, indicam equilíbrio na abrangência da análise. O percentual de

\footnotetext{
${ }^{37}$ Azzoni (1982b) lembra que o fato de a empresa não ter optado pela última alternativa de nada indica que ela se aproximou de uma solução ótima.
} 
$29,6 \%$ foi relativo tanto para a categoria apenas dentro do estado, como para as categorias tanto dentro como fora do Centro-Oeste e não considerou alternativas. Assim, apenas 11,1\% das empresas consideram apenas regiões dentro do Centro-Oeste.

Dos cruzamentos mais interessantes com as características, destacam-se:

* das empresas que tiveram a maior amplitude de análise (dentro e fora do CentroOeste), $75 \%$ são grandes e $25 \%$ médias (veja percentuais em coluna na Tabela 14a no Anexo A); 87,5\% são empresas que fazem integração vertical; 87,5\% tinham como meta principal, desde que tomou a decisão de abrir a unidade, minimizar custos de abastecimento de matérias-primas;

* Já aquelas que não consideraram alternativas, 50\% são pequenas e 37,5\% médias; $62,5 \%$ constituem-se de um novo negócio; $50 \%$ são integradoras e 37,5\% apenas compram animais no mercado para abater; $75 \%$ disseram que a principal meta era apenas iniciar uma nova atividade como outra qualquer;

* Dos 29,6\% das empresas que apresentaram a menor amplitude da análise (apenas dentro do estado) $50 \%$ são pequenas e $25 \%$ são médias; $66,7 \%$ mantêm estrutura independente de produção;

* Atentando-se para os dados em linha e não mais em coluna (Tabela 14b no Anexo A), nota-se que entre as empresas categorizadas como pequenas, ou elas restringiram a análise dentro do estado (50\%) ou elas não consideraram alternativas (50\%);

* Ainda na Tabela 14b no Anexo A, salienta-se que dos 40,7\% das empresas que responderam n.d.a. (apenas iniciar uma nova atividade produtiva como outra qualquer) na questão 5, 45,5\% limitaram o estudo ao estado e 54,5\% não estudaram alternativas. Já para aquelas cujo intuito era o de minimizar custos de abastecimento de milho, 77,8\% mostraram amplitude máxima, ou seja, todas as regiões do Brasil;

\subsubsection{Duração do processo de escolha}

As maiores freqüências relativas registradas foram para a opção mais de 12 meses (37\%) e não estudou a localização (29,6\%). Além destas, 14,8\% das empresas estudaram de 1 a 5 meses e 18,5\% estudaram de 6 a 12 meses. 
As principais constatações que podem ser feitas quando do cruzamento desta variável com as características consideradas são as seguintes:

Das empresas que dispenderam maior tempo no estudo da localização, $70 \%$ são grandes e 20\% médias; $90 \%$ são integradoras; $60 \%$ tinham na minimização dos custos de abastecimento de milho a principal meta (Tabela 14a no Anexo A);

- Já dos quase 30\% das empresas que não estudaram a localização, 37,5\% são pequenas e $50 \%$ são médias; $50 \%$ são um novo negócio e $50 \%$ são uma expansão regional; 75\% tinham como meta principal apenas iniciar uma atividade como outra qualquer (Tabela 14a no Anexo A);

Já foram salientadas as justificativas para que um tempo razoável seja gasto no estudo do local que uma empresa irá se (re)localizar ou abrir uma filial. Além disso, este tempo deve ser maior para empresas grandes que estariam imobilizando grande quantidade de ativos. Townroe $(1971)^{38}$, citado por Azzoni (1982b), em sua pesquisa de 87 empresas na Grã Bretanha, verificou que mais da metade levaram mais de 2 anos para se decidirem, cerca de $25 \%$ levaram de 1 a 2 anos e quase $20 \%$ levaram menos do que 2 anos. Já o trabalho de Azzoni (1982b), que estudou o processo de decisão locacional de 581 empresas paulistas que solicitaram licença de operação de 1977 a 1979, mais da metade levou 5 meses ou menos para escolher o local, enquanto $21 \%$ levaram 1 ano ou mais.

Os resultados da relação entre tamanho e duração do processo de escolha desta pesquisa são análogos aos resultados obtidos por Azzoni (192b). Ambos trabalhos mostram que empresas maiores gastaram mais tempo no processo de escolha do local definitivo (63,6\% dos abatedouros grandes de aves e suínos gastaram mais de 12 meses para estudar a localização). No entanto, estas evidências contrariam os resultados obtidos por Townroe (1971) citado por Azzoni (1982b), onde este último comenta que o trabalho daquele revela que empresas maiores teriam maior capacidade de mobilização de técnicos que poderiam finalizar a pesquisa em curto prazo. Já as pequenas teriam uma

\footnotetext{
38 TOWNROE, P.M. Industrial location decisions. A study in management behaviour. Centre for Urban and Regional Studies, University of Birminghan. Occasional paper $n^{\circ} 15$, Birminghan, England, UK, 1971.
} 
inércia locacional em função da sua baixa capacidade de alocar pessoal qualificado no estudo.

Entretanto, o fato de que a maioria das empresas grandes $(54,5 \%)$ apresentou a maior amplitude de análise (ou seja, regiões dentro e fora do Centro-Oeste) conforme visto no item anterior, corrobora para a sustentação da idéia de que empresas grandes levam mais tempo para se decidirem sobre a problemática locacional.

Outra explicação para que as empresas pequenas não dispendam muito tempo na análise do local ou sequer estudem a localização é que elas, pelo fato de conhecerem muito melhor do que as outras os mercado regionais em que operam, possuem uma natural vantagem comparativa e, portanto, apresentam uma baixa propensão a um estudo abrangente ou mesmo mudança locacional.

\subsubsection{Opção pela última alternativa}

Resgatando a idéia desta questão, a de detectar se o comportamento das empresas estaria mais próximo de uma atitude otimizadora do que satisfação de requisitos mínimos, vê-se na Tabela 14 no Anexo A que apenas $14,8 \%$ das empresas optaram pelo último local a ser analisado, 51,9\% não optaram pelo último local e 33,3\% não consideraram alternativas, tendo assim a idéia pré-determinada de se estabelecerem naquele ambiente.

Analisando as freqüências relativas de cada categoria da variável última, calculadas através das características consideradas (Tabela 14a no Anexo A, que traz as freqüências calculadas em coluna), destacam-se:

* Das empresas que optaram pelo último local a ser analisado, $75 \%$ são médias e $25 \%$ são grandes; 75\% constituem-se num novo negócio;

* Já das empresas que não optaram pela última alternativa, ou seja, que continuaram realizando a pesquisa na direção de um "ótimo", 64,3\% são empresas grandes; $78,6 \%$ são integradoras e $50 \%$ tinham na minimização de custos de abastecimento de matérias-primas, a principal meta;

- Das 33,3\% das empresas que sequer estudaram alternativas, quase 90\% eram pequenas $(44,4 \%)$ ou médias $(44,4 \%)$; nenhuma se constitui em uma expansão de 
empresas cuja origem não é o Centro-Oeste e quase $80 \%$ tinham como meta principal quando da idealização do negócio apenas iniciar uma atividade produtiva como outra qualquer.

Analisando agora as freqüências relativas de cada categoria das variáveis de característica, calculadas através das categorias da variável última (Tabela 14b no Anexo A, que traz as freqüências calculadas em linha), destacam-se:

* Cerca de $82 \%$ das empresas categorizadas como grandes, o local definitivo por elas escolhido não foi a última alternativa a ser pesquisada;

* Outra constatação interessante é que 85,7\% das empresas que se constituem numa expansão de uma empresa cuja origem não é o Centro-Oeste (talvez o agrupamento que melhor ilustre o paradigma de atração das regiões de cerrado pelas empresas ligadas aos segmentos de aves e suínos), o local definitivo por elas escolhido não foi a última alternativa a ser pesquisada.

Em suma, o que pode ser dito é que as empresas de maior porte mostraram um comportamento mais coerente de quem otimiza uma pesquisa do que de quem se satisfaz com características mínimas atingidas.

Importante fazer uma ressalva de que o "ótimo" é um objetivo absolutamente subjetivo. Aquilo que é considerado como quesitos básicos de uma pesquisa de alguém que busca o melhor local para se estabelecer pode não ter nada a ver com as pretensões de uma empresa com base familiar. Para esta, o ótimo pode ser localizar-se ao lado da fazenda onde mora, explorando um mercado local que conhece muito bem.

Portanto, o caráter otimizador aqui avaliado, está baseado apenas em pressuposições teóricas, talvez neoclássicas. Mesmo porque, apenas o fato de uma empresa estudar a sua localização, por mais curto período que seja ou mesmo sendo a última opção a escolhida, evidencia o comportamento de alguém que otimiza. No caso, buscando, por exemplo, minimizar custos administrativos e de abastecimento, maximizar vendas com ampliação de mercado consumidor, etc. 
4.3.1.4 Elaboração pela empresa do perfil da localização procurada

Observando a Tabela 14 no Anexo A, nota-se que a proporção de empresas que elaboraram $(44,4 \%)$ ou não elaboraram $(56,6 \%)$ um perfil da localização que almejavam difere pouco. Das empresas que elaboraram um perfil, metade teve este perfil alterado parcialmente ao longo do tempo da análise, o que indica uma certa propensão adaptativa das empresas conforme foram se deparando com os ambientes produtivos nas regiões de estudo.

Vale ressaltar o significativo percentual de empresas que não havia formalizado um perfil do local que buscavam somado àquelas que afirmaram ter alterado parcialmente os requisitos que buscavam: 78,8\%. Esta constatação sugere um comportamento não maximizador por parte dos empresários mas sim sintomas de adaptação da firma a um ambiente de mudanças, como sugere Townroe (1972).

Interessante ressaltar as seguintes constatações detectadas na Tabela 14b no Anexo A, que contrapõe as diversas características das empresas com a variável perfil, obtendo freqüências relativas no sentido das linhas.

- Das empresas integradas, metade havia elaborado perfil e a outra metade não;

* Dos 33,3\% das empresas que tinham como meta principal a minimização dos custos de abastecimento de matérias-primas, 77,8\% haviam elaborado um perfil do local almejado, talvez aquele que justamente contemplasse minimizar gastos com a compra de milho;

* Já das empresas que disseram que a meta era apenas iniciar uma atividade como outra qualquer, quase $73 \%$ não desenharam perfil almejado.

\subsubsection{Informações utilizadas na análise do local definitivo}

Na Figura 18 estão dispostos os resultados da questão 9 (ver detalhes no questionário no Anexo B) que pretendeu avaliar o quanto as empresas se muniram de informações para buscar o local que melhor se adequasse as suas exigências. Os objetivos desta avaliação são completados com a questão 10, discutida na seqüência. 
Como já era esperado, o procedimento mais comum foi a avaliação da disponibilidade de milho, superando até mesmo um item que, a princípio, parecia ser elementar, como a visita à cidade. Excetuando o item utilização de consultor externo, os outros procedimentos apresentaram respostas afirmativas na faixa dos $40 \%$ a $50 \%$.

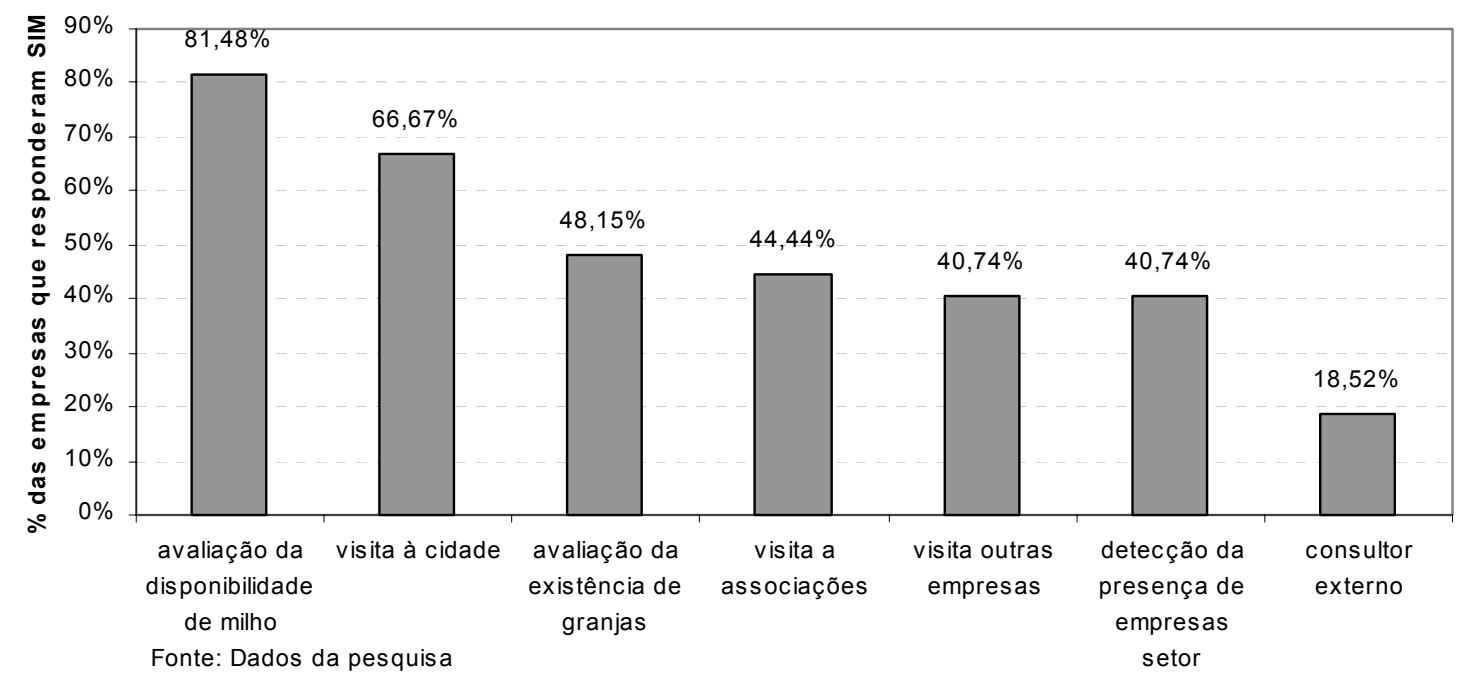

Figura 18 - Informações utilizadas pelas empresas na análise do local definitivo

A Tabela 15 no Anexo A apresenta as respostas das empresas com relação a cada informação que foi ou não usada na análise do local definitivo, discriminada para cada característica da empresa considerada. Em virtude da grande quantidade de cruzamentos, tanto em coluna (Tabela 15a no Anexo A) como em linha (Tabela 15b no Anexo A), deter-se-á apenas em apresentar os cruzamentos no Anexo A.

\subsubsection{Comparações monetárias}

Na Figura 19 estão dispostos os resultados da questão 10 que, juntamente com a questão 9, buscou identificar o nível de sofisticação do estudo de localização das empresas de abate de aves e suínos no Centro-Oeste. Desta vez, questionando se as empresas realizaram ou não comparações monetárias dos preços das matérias-primas, do custo da mão-de-obra, do preço da terra e do transporte de produtos e matérias-primas. 


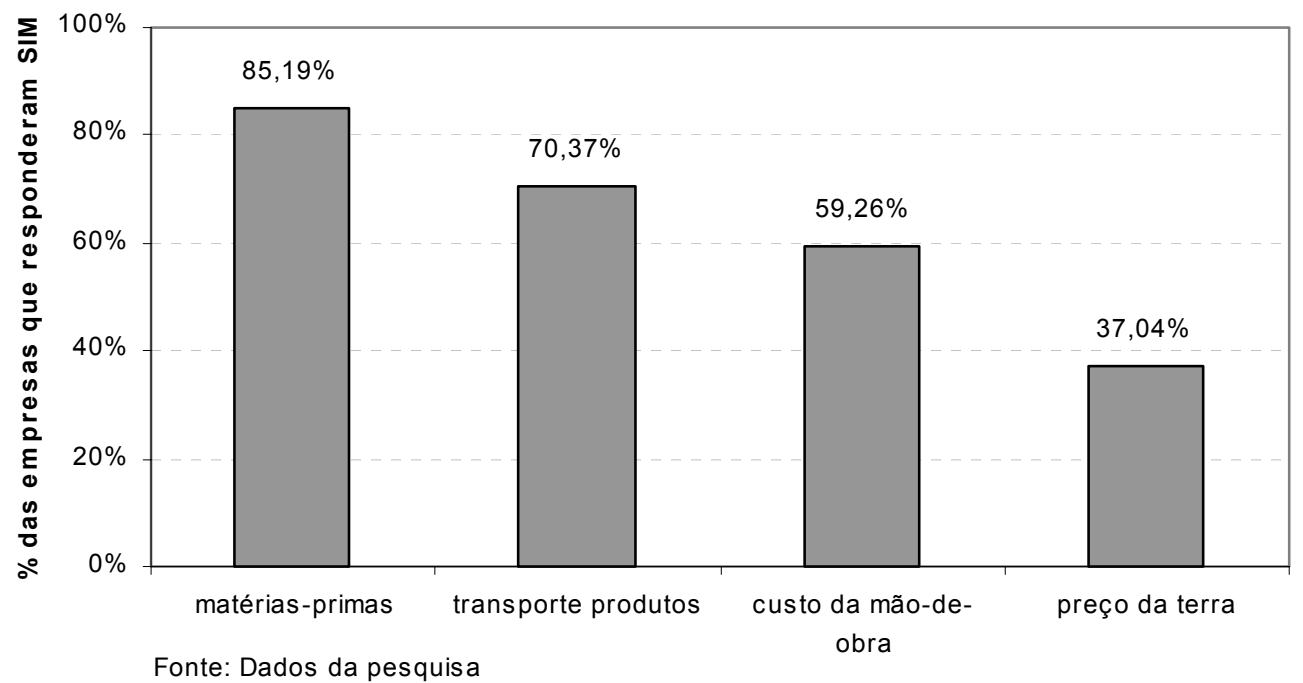

Figura 19 - Percentual dos itens em que comparações monetárias foram realizadas pelas empresas

O elevado percentual $(81,2 \%)$ de empresas que afirmaram ter feito comparações monetárias dos preços das matérias-primas já era esperado a priori, graças à importância do milho e do farelo de soja nos custos de produção dos animais vivos. As comparações monetárias dos custos de transporte de matérias-primas, com $70,4 \%$ de empresas respondendo "sim" foi o segundo item maior freqüência.

À semelhança da questão anterior, os cruzamentos de cada variável presente em comparações monetárias com as distintas características consideradas estão na Tabela 16 no Anexo A.

\subsubsection{Intensidade do estudo da localização}

Esta variável foi construída a posteriori da aplicação do questionário, num esforço de se tentar coadunar as 6 variáveis de decisão locacional num só fator, denominado intensidade. Para isso, contou-se com um pouco de arbitrariedade, alicerçada, no entanto, no trabalho de Azzoni (1982b) que utilizou scores para graduar as variáveis que diziam respeito às informações utilizadas no estudo da localização bem como nas comparações monetárias que foram feitas. 
Dessa forma, as primeiras questões em que se procedeu à atribuição de scores foram a 9 e a 10. A intenção foi atribuir maiores notas às informações que apresentaram as menores freqüências. É bastante razoável supor que as modalidades de maior sofisticação apresentem as menores freqüências, como o caso da modalidade utilização de consultor externo, usado em apenas 19\% das empresas respondentes. Para tanto, o artifício utilizado por Azzoni (1982b) foi o de calcular o logaritmo do inverso da freqüência relativa, solução aplicada em cada item das questões 9 e 10. Os scores obtidos podem ser vistos na Tabela 7.

Tabela 7. Scores atribuídos a cada item das informações utilizadas (questão 9) bem como das comparações monetárias (questão 10)

\begin{tabular}{lccc}
\hline \multicolumn{1}{c}{ Questão } & frequência $\left(n_{i}\right)^{*}$ & frequência relativa $\left(n_{i} / \mathrm{N}\right)$ & $\log \left(n_{i} / \mathrm{N}\right)^{-1}$ \\
\hline Informação utilizada (questão 9) & & & 0,089 \\
avaliação da disponibilidade de milho & 22 & 0,81 & 0,176 \\
visita à cidade & 18 & 0,67 & 0,317 \\
avaliação da existência de granjas & 13 & 0,48 & 0,352 \\
visita a associações & 12 & 0,44 & 0,390 \\
visita outras empresas & 11 & 0,41 & 0,390 \\
detecção da presença de empresas setor & 11 & 0,41 & 0,732 \\
consultor externo & 5 & 0,19 & 0,070 \\
Comparações monetárias (questão 10) & & & 0,153 \\
matérias-primas & 23 & 0,85 & 0,227 \\
transporte de produtos & 19 & 0,70 & 0,431 \\
custo da mão-de-obra & 16 & 0,59 & 0,37 \\
preço da terra & 10 & &
\end{tabular}

Fonte: Dados da pesquisa

* relativo ao número de respostas "sim"

Para as demais questões $(7,8,11$ e 12), decidiu-se, na tônica do método usado nas questões 9 e 10, atribuir scores mais altos para as respostas que indicavam maior esmero no estudo locacional, seja ele por ser mais abrangente, de maior duração, por não ter sido a última alternativa a ser escolhida ou porque foi relativo a uma préelaboração do perfil almejado do local.

Assim, foi considerada a escala de scores mostrada na Tabela 8, baseada num valor médio dos scores obtidos nas questões 9 e 10. 
Tabela 8. Scores atribuídos a cada item das questões 7, 8, 11 e 12

\begin{tabular}{ccccc}
\hline Amplitude & Duração & Última & Perfil & Score \\
\hline não considerou alternativas & não & não estudou alternativas & não & 0,00 \\
dentro do estado & 1 - 5 meses & foi a última alternativa & sim & 0,25 \\
dentro do C.O. & $6-12$ meses & não foi a última alternativa & & 0,50 \\
todas as regiões & + de 12 meses & & & 0,75 \\
\hline
\end{tabular}

Fonte: Dados da pesquisa

Depois de definidos os scores individuais de cada questão do grupo variáveis de decisão, a nova variável criada, intensidade do estudo, foi obtida através do somatório de todos os scores parciais obtidos nas questões de 7 a 12. Assim sendo, poder-se-ia considerar que a fronteira teórica do estudo mais bem elaborado teria um valor máximo de 5,57 pontos, relativos a uma empresa que considerasse todas as regiões do Brasil no estudo, estudasse durante mais de 12 meses a localização, tivesse usado todas as informações disponíveis na questão 9, tivesse realizado todas as comparações monetárias disponíveis na questão 10 , cujo local de escolha não tivesse sido a última alternativa a ser considerada e que ela tivesse elaborado um perfil ótimo da localização.

Para efeito da construção de tabelas de contingência, foram criadas três categorias de intensidade de estudo - pequena, média e grande -, cujos limites foram obtidos a partir da fronteira teórica de máximo estudo para a definição de intervalos eqüidistantes: de 0 a 1,86 pontos (pequena intensidade de estudo), de 1,87 a 3,72 pontos (média intensidade de estudo) e de 3,73 a 5,57 pontos (grande intensidade de estudo).

Os resultados obtidos após a categorização desta variável podem ser vistos na Tabela 14 no Anexo A, que traz também os cruzamentos com as características das empresas. Dentre as constatações mais interessantes, destacam-se:

* Das empresas classificadas como pequena intensidade de estudo, 37,5\% são de tamanho pequeno e $50 \%$ são de tamanho médio; metade são relativas a um novo negócio e a outra metade a uma expansão regional; $75 \%$ tinham como meta principal apenas iniciar uma atividade produtiva como outra qualquer (a opção n.d.a. da questão 5);

* Com relação às empresas classificadas como grande intensidade de estudo, 62,5\% são de tamanho grande e $25 \%$ são de tamanho pequeno; $62,5 \%$ tinham como meta 
principal a minimização dos custos de abastecimento de matérias-primas e $25 \%$ acompanhar a tendência da nova geografia do setor para regiões de fronteira.

\subsubsection{Resultados dos testes de hipótese}

O objetivo essencial de se submeter os cruzamentos das variáveis de característica com as variáveis locacionais aos testes de hipótese é o de testar a dependência entre pares de variáveis. As várias tabelas de contingência que foram inicialmente construídas são àquelas encontradas nas células da Tabela 14 no Anexo A. Salienta-se que será adotado o nível de significância mínimo para rejeição do teste (e conseqüente aceitação de dependência entre as variáveis) de 5\%.

Os resultados dos testes qui-quadrado aplicados às tabelas de contingência oriundas da Tabela 14 no Anexo A estão expostos na Tabela 9.

Tabela 9. Resultados dos testes de hipótese para os cruzamentos dos pares de características com variáveis de decisão locacional

\begin{tabular}{lccccc}
\hline \multirow{2}{*}{ Característica } & \multicolumn{3}{c}{ Variáveis de decisão } \\
& Amplitude $^{(2)}$ & Duração $^{(2)}$ & Última $^{(3)}$ & Perfil $^{(5)}$ & Intensidade $^{(3)}$ \\
\hline Tamanho & $5,644^{\text {n.s. }}$ & $4,017^{\text {n.s. }}$ & $6,758^{\text {n.s. }}$ & $0,703^{\text {n.s. }}$ & $2,330^{\text {n.s. }}$ \\
Status & $10,824^{\text {n.s. }}$ & $5,097^{\text {n.s. }}$ & $4,723^{\text {n.s. }}$ & $0,256^{\text {n.s. }}$ & $1,743^{\text {n.s. }}$ \\
Estrutura & $1,783^{\text {n.s. }}$ & $2,756^{\text {n.s. }}$ & $1,205^{\text {n.s. }}$ & $1,013^{\text {n.s. }}$ & $2,994^{\text {n.s. }}$ \\
& Amplitude $^{(1)}$ & Duração $^{(1)}$ & Última $^{(2)}$ & Perfil $^{(4)}$ & Intensidade $^{(2)}$ \\
Meta & $11,658^{\text {n.s. }}$ & $15,499^{\text {n.s. }}$ & $19,956^{* * *}$ & $9,478^{* *}$ & $16,202^{* *}$ \\
\hline
\end{tabular}

Fonte: Dados da pesquisa

(1) 9 graus de liberdade $\left(\chi_{5 \%}^{2}=16,919 / \chi_{2,5 \%}^{2}=19,023 / \chi_{1 \%}^{2}=21,666\right)$

(2) 6 graus de liberdade $\left(\chi_{5 \%}^{2}=12,592 / \chi_{2,5 \%}^{2}=14,449 / \chi_{1 \%}^{2}=16,812\right)$

(3) 4 graus de liberdade $\left(\chi_{5 \%}^{2}=9,488 / \chi_{2,5 \%}^{2}=11,143 / \chi_{1 \%}^{2}=13,277\right)$

(4) 3 graus de liberdade $\left(\chi_{5 \%}^{2}=7,815 / \chi_{2,5 \%}^{2}=9,348 / \chi_{1 \%}^{2}=11,345\right)$

(5) 2 graus de liberdade $\left(\chi_{5 \%}^{2}=5,991 / \chi_{2,5 \%}^{2}=7,378 / \chi_{1 \%}^{2}=9,210\right)$

n.s. - teste não significativo a $5 \%$ (não se rejeita $\mathrm{H}_{0}$ )

* teste significativo a $5 \%$

${ }^{* *}$ teste significativo a $2,5 \%$

$* * *$ teste significativo a $1 \%$ 
Antes mesmo de se realizarem os testes de hipótese de cada cruzamento da Tabela 14 no Anexo A para detectar de fato a existência de dependência entre as variáveis, pode-se dizer, através da estatística descritiva dos itens precedentes, que as empresas grandes apontavam caminhar no sentido de estudos mais elaborados do que as pequenas, seja pela constatação da variável intensidade do estudo que consolida as outras 6, ou pelo exame individual de cada uma delas.

Entretanto, a deteç̧ão de testes não significativos para todos os cruzamentos das características tamanho, status e estrutura com as variáveis de decisão amplitude, duração, última, perfil e intensidade impede que todas as hipóteses de nulidade de cada teste individual sejam rejeitadas, acarretando numa aceitação de independência entre as variáveis.

Desse modo, o fato de os abatedouros de aves e suínos ter realizado estudo mais ou menos elaborado, não depende do tamanho da empresa, do status em que se configura o negócio e do tipo de estrutura, se integrada ou não. Em outras palavras, há que se rejeitar as hipóteses estabelecidas no início deste capítulo, que defendiam a existência de dependência entre os pares de variáveis analisados.

Todavia, a dependência que não foi captada pelas três características acima descritas, foi detectada pela característica meta, que só não apresentou testes significativos quando cruzada com as variáveis de decisão amplitude e duração, sendo que este último cruzamento seria significativo ao nível de significância $(\alpha)$ de 10\%.

$\mathrm{O}$ fato de apenas a característica meta ter apresentando testes significativos vis-a-vis a não captação de dependência por parte das características tamanho, status e estrutura, implica interessantes constatações.

Primeiramente vale dizer que as hipóteses levantadas para as variáveis de decisão locacional haviam sido estabelecidas antes da realização da pesquisa empírica, sobretudo das visitas a algumas empresas da região Centro-Oeste. Assim, não se conhecia de perto a realidade produtiva da região.

Após um maior envolvimento tanto com os empresários dos estabelecimentos abatedouros/frigoríficos da região, como também com as associações de aves e suínos de cada estado, órgãos estaduais competentes pela gestão da defesa 
agropecuária/controle sanitário, a independência constatada entre o esmero do estudo da localização com o tamanho das empresas, por exemplo, não surpreende.

As explicações mais coerentes do porquê dos testes terem sido em sua grande maioria não significativos (obrigando a não rejeição da hipótese de independência entre as variáveis) seriam:

- Das empresas classificadas como grande, mesmo sendo a maioria $(63,6 \%)$ relativa a uma expansão de empresas cuja origem não é o Centro-Oeste, constatou-se proporções consideráveis tanto para a categoria novo negócio como para expansão regional (18,2\% para cada), sendo ambas caracterizadas por uma baixa freqüência de empresas que desenvolveram um estudo locacional de elevada intensidade $(27,3 \%$ e 22,9\%, respectivamente, como pode ser acompanhado na Tabela 14 no Anexo A);

* Tanto as empresas classificadas como novo negócio como expansão de uma empresa regional (categorias da variável status) apresentaram considerável percentual da categoria integrada: 54,5\% das empresas que se configuram num novo negócio são integradas e 55,6\% das empresas que se constituem em uma expansão regional são integradas;

* Pelo exame da Tabela 14 no Anexo A, lê-se que 62,5\% das empresas pequenas são integradoras, o que de certa forma afasta a idéia original de integração vertical como um sistema representativo das grandes firmas, sejam elas pertencentes ou não aos principais grupos produtivos de aves e suínos como os casos de Perdigão, Sadia, Avipal, Frangosul, Seara, etc. Esta constatação pode ser explicada pela disseminação do modelo de produção integrada entre pequenas e médias empresas. Este sistema produtivo não é mais exclusivo de grandes grupos com maior capacidade de coordenação. Só para se ter uma idéia, detectou-se na pesquisa uma empresa que abate apenas 2.000 frangos por dia e que mantém contratos de integração vertical com granjeiros (o abate diário das grandes integradores gira em torno de 100.000 aves/dia).

O que se quer com apenas estes três comentários é ilustrar a grande variabilidade dos perfis das empresas, sendo complexa a definição de grupos homogêneos em quaisquer das características tamanho, status ou estrutura. 
O mesmo não pode ser dito para a característica meta, que, de maneira um tanto quanto despretensiosa, conseguiu determinar um agrupamento prévio das empresas que as fizesse diferir em seu processo de decisão locacional. Sobremodo entre os grupos de empresas categorizadas com as metas minimizar custos de abastecimento de matérias-primas (leia-se milho) e apenas iniciar uma atividade produtiva como outra qualquer. Assim, seja a empresa grande ou integradora, o fato de ela ter explicitado não haver uma clara pretensão em estar iniciando, expandindo ou relocalizando sua atividade produtiva no Centro-Oeste, denota a sua pequena preocupação com a localização.

Já as empresas que externaram seu principal objetivo de estar se dirigindo para o Centro-Oeste como sendo a minimização dos custos de abastecimento de milho, realizaram pesquisa mais primorosa, mais abrangente e geralmente de maior duração. Além disso, ficam os indícios de que aqueles que certamente buscavam grãos de menor custo, também se preocuparam em pesar e estudar outros fatores auxiliadores das decisões locacionais, objeto de discussão do próximo item.

\subsection{OS FATORES DETERMINANTES DA ESCOLHA DO LOCAL}

Antes de se proceder à exposição dos principais resultados das variáveis chave para a escolha do local definitivo da atividade de aves e suínos, será revista a pressuposição elementar deste estudo das forças locacionais: os preços mais baixos das matérias-primas básicas (em especial o milho) nos estados da região Centro-Oeste não são suficientes para explicar o desenvolvimento das atividades dos complexos de aves e suínos nessa região.

Em outras palavras, as empresas não devem apontar como fatores de grande importância ou decisivos para a escolha do local apenas aqueles relativos às matérias-primas e à mão-de-obra, fatores decisivos na localização industrial nos modelos clássicos de localização, mas também outros tidos como secundários (maior aprofundamento sobre esta discussão encontra-se no Apêndice). 
O exame dos fatores que determinaram a escolha do local definitivo será feito basicamente a partir da análise de cada agrupamento de variáveis contidas na questão 13 do questionário no Anexo B. Os resultados das respostas para cada fator locacional estão apresentados na Figura 20.

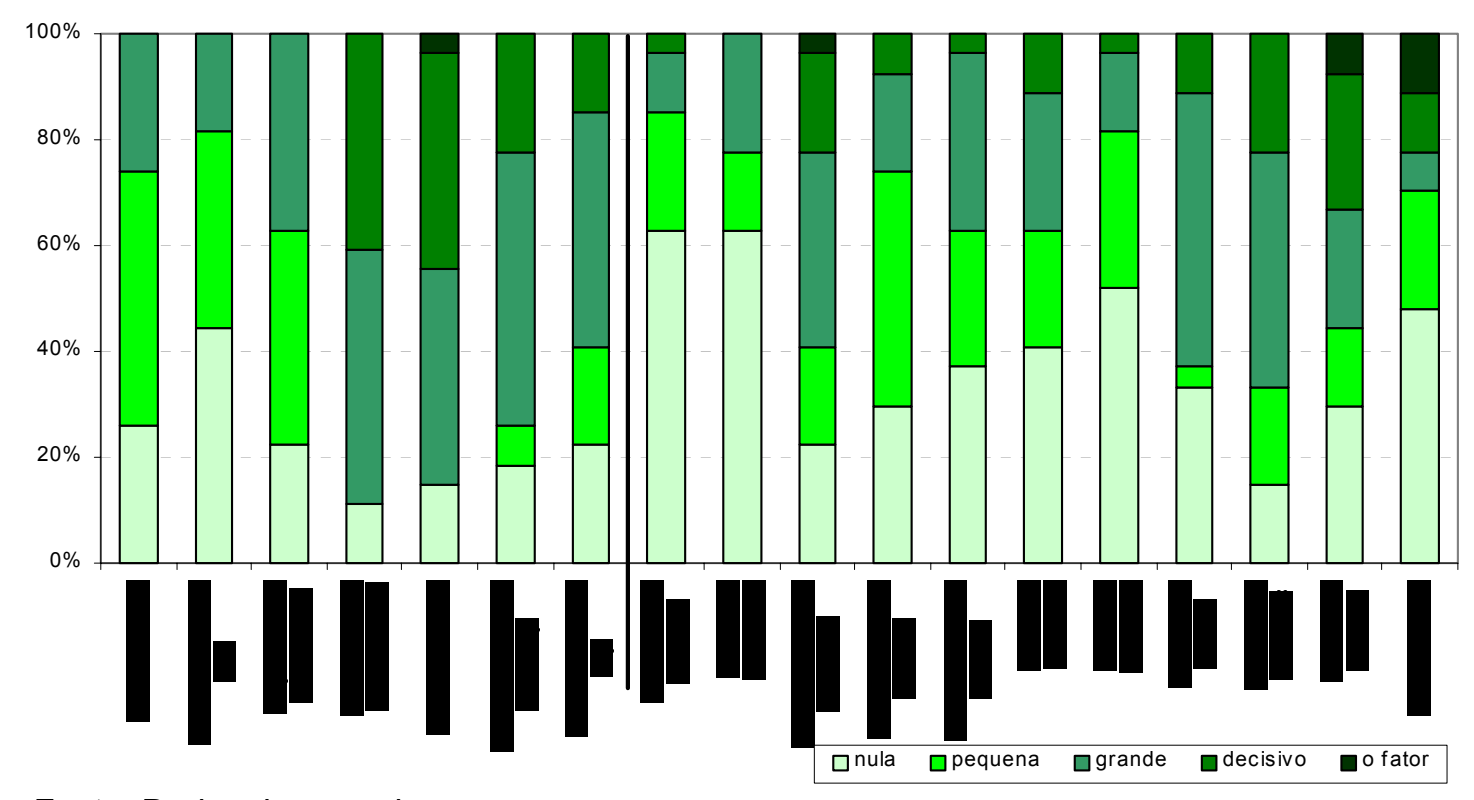

Fonte: Dados da pesquisa

Figura 20 - Importância atribuída pelas empresas a cada fator locacional

Antes de se proceder a qualquer discussão, vale destacar a baixa freqüência de respostas que classificaram os fatores como um dos decisivos ou individualmente causador da escolha, indicando de alguma forma certa dificuldade do respondente em identificar quais teriam sido de fato os fatores que determinaram a escolha, se é que existiram.

Posteriormente foi feita a contagem conjunta das freqüências relacionadas às respostas importância grande (resposta 3 do questionário) e foi um dos fatores decisivos (resposta 4), cruzando-se, para cada variável da questão 13, às características das empresas. Os resultados estão presentes na Tabela 17 no Anexo A, sendo que a 17a apresenta as freqüências relativas calculadas no sentido das linhas, ou seja, a participação individual das categorias de cada variável no total de respostas 3 e 4. Já a Tabela 17b no Anexo A traz as freqüências relativas calculadas no sentido das colunas. 
Como por exemplo, em 17b, a célula que cruza a categoria pequena da variável tamanho com o fator custos salariais apresenta freqüência relativa de $37,5 \%$, que pode ser lida da seguinte forma: das empresas pequenas, $37,5 \%$ considerou os custos salariais um fator de grande importância ou determinante da escolha.

\subsubsection{O fator mão-de-obra}

Ao lado esquerdo da Figura 20, separados por um traço, estão os fatores que poderiam ser classificados como os tradicionais da localização industrial, ou seja, matérias-primas e mão-de-obra. Percebe-se que, enquanto ao fator matérias-primas é atribuída grande importância, o mesmo não pode ser dito da mão-de-obra.

Não se observaram respostas que consideraram quaisquer um dos itens do fator mão-de-obra como um dos fatores determinantes da escolha. Hierarquicamente entre os itens, disponibilidade de mão-de-obra obteve maior quantidade de respostas tipo importância grande (37\%), enquanto custos salariais apresentou $25,9 \%$ e qualidade da mão-de-obra, apenas 18\%.

Este baixo valor de preocupação das empresas com o fator qualidade da mão-de-obra já era esperado e foi discutido no desenvolvimento do problema. Mesmo assim, dentre as empresas que se preocuparam com a qualidade da mão-de-obra, tem-se que $60 \%$ são grandes e $40 \%$ médias; $80 \%$ cuja origem do negócio é uma migração de outras regiões para o Centro-Oeste; $60 \%$ eram integradoras e $40 \%$ apenas abatem os animais que compram (Tabela 17a no Anexo A).

Entretanto, ao se analisar a Tabela 17b no Anexo A, não se pode afirmar que este foi um fator de preocupação entre as empresas, nem mesmo entre as integradoras (onde apenas 16,7\% delas atribuíram importância ao item qualidade da mão-de-obra) que poderiam ter maior cuidado com uma parte integrante fundamental do sistema produtivo: o cooperado.

Se por um lado a qualidade da mão-de-obra não aparentou ser um fator de preocupação entre as integradoras na escolha da localização, ela parece ter emergido como um problema a posteriori. 
A constatação de entraves ligados à implementação do modelo de integração vertical no Centro-Oeste foi praticamente unânime na visão das integradoras visitadas em Goiás e em Mato Grosso, bem como na opinião das associações de aves e suínos da região. Já no Mato Grosso do Sul, o perfil dos cooperados que se motivaram a associar à produção integrada de aves e suínos apresentou maior adaptação ao modelo, principalmente pelo fato de o estado ter sido ponto de chegada de migrantes nordestinos, paulistas e paranaenses, produtores agrícolas geralmente de pequeno/médio porte, mais maleáveis ao sistema.

Os maiores obstáculos que algumas empresas goianas e mato-grossenses passaram foram com o modelo de integração vertical conduzido na essência do Sul do país, mesmo tendo sido redesenhado em moldes mais avantajados. O perfil do integrado potencial do local é deveras distinto do sulino. Mesmo os grandes grupos já tendo antecipado esta característica, as dificuldades pareceram ter sido maiores do planejado. Nestas regiões, geralmente o produtor agrícola é um empresário, grande produtor de gado ou de grãos (basicamente milho e soja) que não depende exclusivamente da terra para viver. A opção pela avicultura e/ou suinocultura seria encarada e analisada como outro investimento qualquer.

Atentando-se agora à primeira linha da Tabela $17 \mathrm{~b}$ no Anexo A, vê-se que nem mesmo as grandes empresas, as integradoras, ou as que se constituíam numa expansão oriunda de outra região que não o Centro-Oeste, apresentaram parcela apreciável que considerou o item custos salariais como importante na escolha do local. Portanto, mesmo que o Centro-Oeste apresentasse de fato mão-de-obra mais barata que outras regiões, paradigma que envolve regiões fronteiriças, não seria fator de atração às empresas de aves e suínos.

\subsubsection{O fator matérias-primas}

O fator matérias-primas, representado por quatro itens (proximidade ao milho e ao farelo de soja e nível de custo do milho e do farelo de soja), foi aquele em que nitidamente se atribuiu maior importância, em especial aos itens relacionados ao 
milho (Figura 20). Importante destacar ainda que este fator foi o que obteve o maior número de notas do tipo foi um dos fatores decisivos, sendo o nível de importância caminhando sempre em sentido decrescente do milho para a soja e da proximidade para os custos.

Em virtude da grande maioria das empresas ter demonstrado a vital importância das matérias-primas na escolha do local definitivo, como pode ser acompanhado na coluna marginal da Tabela 17a no Anexo A (excetuando o item nível de custo do farelo de soja), este fator acabou apresentando um comportamento indiscriminado com relação às características consideradas. Em outros termos, a atribuição de grande importância às matérias-primas é praticamente indiferente do tamanho, do status, da origem, da estrutura e da meta da firma. Ela é quase unânime.

Mesmo assim, vale a pena destacar resultados interessantes, como o fato de $100 \%$ das empresas pequenas ter atribuído a todos os itens do fator matérias-primas elevada importância ou um dos decisivos na escolha (Tabela 17b no Anexo A). Uma das razões para isso seria que as empresas pequenas têm maior dificuldade de detectar outros fatores tão importantes quanto o favorecimento das fontes de matérias-primas. Acabam por perceber apenas os mais diretos e facilmente identificáveis como os preços das matérias-primas.

Os resultados obtidos nos dois fatores locacionais estão de acordo com o esperado. Ou seja, matérias-primas seria o fator de maior importância entre todos, acima da importância atribuída à mão-de-obra.

\subsubsection{O fator ambiente}

O fator ambiente, representado pelos itens problemas de expansão em outras regiões, problemas ligados ao meio-ambiente (manejo de dejetos) e atratividade do ambiente apresentou resultados que, de certa forma contrariam a pressuposição de que as empresas que figuram como uma expansão de regiões externas ao Centro-Oeste (em especial Sul do país) ou cuja origem é uma migração de outras regiões para os cerrados, estariam recebendo uma pressão do ambiente para mudanças. 
Com relação ao primeiro item, problemas de expansão em outras regiões, apenas cerca de $15 \%$ das empresas atribuíram a este fator importância como influente na localização (Tabela 17a no Anexo A). Já das empresas que manifestaram importância para o item que buscou captar uma pressão de saída por conta de problemas ambientais relacionados ao manejo de dejetos (segundo item do fator ambiente), nota-se uma certa concentração da manifestação de importância grande ou decisiva por parte de empresas que se constituíam numa migração $(66,7 \%)$ e também por aquelas que são uma expansão de uma empresa cuja origem não é o Centro-Oeste.

Contudo, ressalta-se que se esta pressão estivesse de fato acontecendo, ela estaria incidindo prioritariamente sobre empresas que estariam se relocalizando, status de empresa não captado nesta pesquisa.

Analisando agora na Tabela $17 \mathrm{~b}$ no Anexo A os resultados dos cruzamentos com o item boas condições para futuras expansões/atratividade do ambiente, vale destacar que, das empresas grandes, aproximadamente 73\% atribuíram grande importância a este fator.

Talvez o mais interessante de se ressaltar com relação ao fator ambiente é que tanto o item problemas de expansão como o item problemas ligados ao meioambiente (manejo de dejetos) foram aqueles que obtiveram as maiores freqüência de importância nula (veja Figura 20), negligência feita muitas vezes por empresas em que se esperava uma atribuição de importância para estes fatores, como as grandes, as integradoras e as contidas dentro de um movimento de expansão para o Centro-Oeste.

\subsection{4 $O$ fator infra-estrutura}

Em seus dois itens de investigação, disponibilidade de serviços diversos e qualidade da infra-estrutura, notou-se que o aspecto infra-estrutura foi pouco importante para a escolha do local das empresas de aves e suínos no Centro-Oeste. Quase $75 \%$ para o item disponibilidade de serviços e pouco mais de $60 \%$ para a qualidade da infra-estrutura, foram os percentuais importância nula e importância pequena contabilizados juntos. 
Estes resultados estão de acordo com as conclusões do trabalho de Peck (1996) que afirma que a infra-estrutura raramente é fator decisivo na escolha do local produtivo. Ela é sempre necessária mas não é suficiente. Outra idéia desenvolvida pelo autor (id. ibid.) é que recentemente a infra-estrutura presente nas regiões não tem se configurado mais como um grande atrativo pelo fato de os programas de desenvolvimento regional dos governos passarem a adotar políticas de "comprar" a presença de grandes empresas com a garantia de personalização a posteriori do espaço físico.

Evidentemente que a realidade física da produção da Inglaterra difere muito da brasileira, sobretudo no ramo agroindustrial de regiões remotas. Portanto, a comparação fica comprometida.

Mesmo assim, há que se admitir que a infra-estrutura, da maneira como Peck (1996) a define - fornecedora de bases coletivas e de integração asa atividades econômicas -, é um fator importante para o desenvolvimento de qualquer atividade produtiva, seja ela mais ou menos dependente de matérias-primas localizadas e seja ela mais ou menos centrada em processos dependentes de alta tecnologia.

Nas décadas de 70 e principalmente 80 , ficou evidente a preocupação dos governos, através dos organismos de desenvolvimento regional, rapidamente construir a infra-estrutura a fim de criar bases mínimas para que projetos de investimento migrassem para o Centro-Oeste. No entanto, similarmente ao que foi constatado por Peck (1996), nos últimos anos, o investimento em infra-estrutura tem se tornado mais flexível, indo de encontro aos requisitos de certas atividades que apresentam grande potencial de crescimento. Um exemplo atual que ilustra esta situação é a criação dos corredores de exportação de soja no Norte do país, como o complexo AraguaiaTocantins.

Com relação às empresas de aves e suínos, o que se pode afirmar é que, se por um lado há a necessidade de requisitos mínimos de infra-estrutura para que o projeto de investimento apresente maior potencial para prosperar, tanto para a produção em si como para o acesso aos mercados, por outro percebeu haver também uma tendência para a busca de locais pouco explorados em termos de atividades produtivas, 
numa atitude de pioneirismo. Para tanto, o requisito mínimo seria a presença de excedente de milho. Além disso, com respeito aos grandes grupos de produção de aves e suínos, notou-se, não de forma explícita mas sim tácita, a necessidade de acompanhar a tendência de avanço no Centro-Oeste, seguindo os passos das concorrentes.

Assim, para as empresas que já haviam decidido "ir para o Centro-Oeste", havia conhecimento por parte dos empresários que a infra-estrutura seria um entrave, dependendo da região de escolha. Dessa forma, seria uma das maneiras para explicar a razão de o fator infra-estrutura ter peso secundário na escolha do local. É como se as empresas já tivessem assimilado que elas poderiam construir a infra-estrutura $a$ posteriori.

Todavia, há que se frisar que a infra-estrutura como um todo reflete indiretamente nos custos das matérias-primas, no acesso aos mercados, nos custos salariais, etc. Porém, este fato deve ter sido negligenciado pela pessoa questionada, pois ela por vezes se atentaria mais a um fator do que a sua causa.

Esta seria uma outra justificativa do porquê empresas que se instalaram no Centro-Oeste para a produção de aves e/ou suínos teriam dado pouco importância à infra-estrutura como fator decisivo na escolha locacional.

Ademais, o próprio tempo que separa a realização da pesquisa com a época de tomada de decisão produtiva de várias empresas, corrobora que o fator infraestrutura foi sub-avaliado.

Na Figura 21 estão representados os dados da pergunta 14 que pretendeu avaliar a nota que as empresas deram para o local onde estão instaladas. Com exceção dos itens gás/eletricidadelágua e meio ambiente (itens de melhores notas), todos os outros apresentaram considerável percentual de respostas precária e razoável, principalmente os relacionados a transporte (tanto público como de cargas - estradas intermunicipais). 


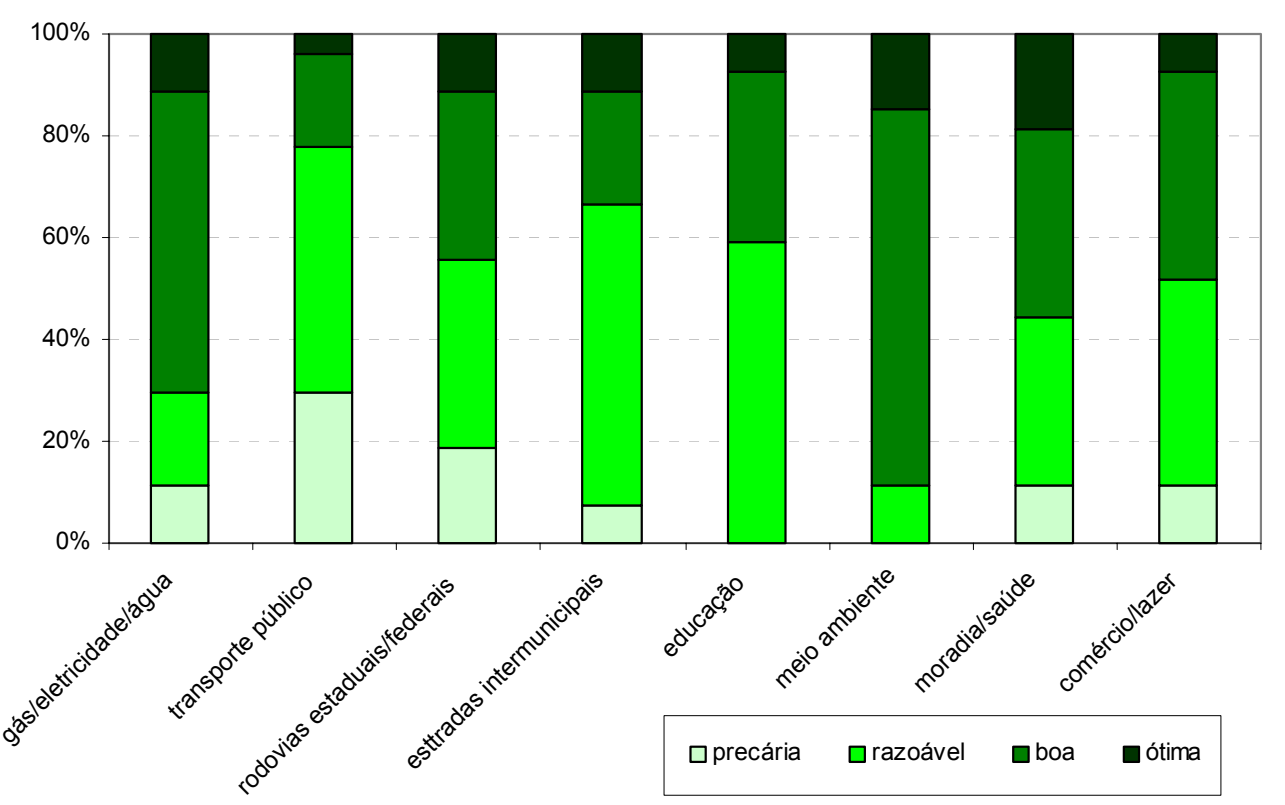

Fonte: Dados da pesquisa

Figura 21 - Freqüência das notas dadas pelas empresas para qualificar cada item da infra-estrutura

Moore, Tyler e Elliot (1991), apesar de detectarem importância atribuída a quesitos de infra-estrutura na escolha do local produtivo por empresas médias da Europa, destacam que a mesma só desponta como um problema depois que as firmas estão estabelecidas. É como se elas passassem a sofrer de fato com os problemas da infra-estrutura após se estabelecerem. Alguns resultados desta pesquisa, como o elevado percentual de empresas insatisfeitas com o transporte, somados às evidências detectadas no trabalho de campo, permitem dizer que situação semelhante à encontrada pelos autores (id. ibid.) está ocorrendo com o agronegócio como um todo do Centro-Oeste.

Apesar de as empresas não haverem demonstrado insatisfação com o local de instalação, uma vez que analisando as respostas da pergunta 16 do questionário no Anexo B, nenhuma empresa respondeu não, pôde-se constatar na pesquisa de campo que certas carências de infra-estrutura, negligenciadas no passado, passaram a ser problema. Como exemplo, poder-se-ia citar a distância elevada das granjas aos abatedouros que expõe a precariedade das estradas vicinais, insatisfação captada na questão 15 (Figura 21). 


\subsubsection{O fator poder público}

Pode-se dizer que a influência do poder público no direcionamento das atividades produtivas de aves e suínos, pelo menos àquilo que foi captado pelo questionário, ficou aquém das expectativas. Apenas 37\% das empresas atribuíram grande importância aos incentivos fiscais estaduais, o dobro do percentual observado para os incentivos fiscais municipais. É de se esperar, também, que possa ter havido uma subestimação deste fator em virtude de uma certa aversão por parte de empresários a admitir que receberam incentivos.

Além disso, até mesmo o pessoal de maior hierarquia dentro das empresas, como gerentes e diretores (classes que juntamente com os proprietários formam a quase totalidade do perfil do respondente dos questionários), pode desconhecer favorecimentos do passado.

Entretanto, vale a pena destacar que a percepção de elevada importância para incentivos fiscais estaduais está concentrada, com relação à variável tamanho, nas grandes (60\%); com relação à variável origem nas empresas que se constituem numa migração empresarial para o Centro-Oeste (60\%); com relação à variável estrutura nas integradoras $(100 \%)$ e com relação à variável meta naquelas que tinham como intuito minimizar custos de abastecimento de matérias-primas $(60 \%)$.

\subsection{6 $O$ fator políticas de desenvolvimento regional}

Programas de desenvolvimento regional foi o item que apresentou o quinto maior percentual - 63\% - de empresas que os consideraram como importantes na escolha no local produtivo. Por outro lado, estes $63 \%$ estão bem distribuídos ao longo de cada característica em que os cruzamentos foram feitos (Tabela 17a no Anexo A).

Interessante destacar que, de acordo com a Tabela $17 \mathrm{~b}$ no Anexo A, este percentual de $63 \%$ (relativo às empresas tomadas como um todo) foi superado quando isoladas as empresas pequenas $(87,5 \%)$. Ou seja, $87,5 \%$ das empresas pequenas 
atribuíram grande importância ao fator políticas de desenvolvimento regional. O mesmo ocorreu para as empresas que se configuravam num novo negócio, cuja freqüência foi de $75 \%$

Complementando a análise deste fator, as respostas da questão 15 indicaram que 59\% dos projetos de instalação não estiveram vinculados a nenhum tipo de programa específico de desenvolvimento regional. Dos $41 \%$ que tiveram vínculo a programas de desenvolvimento regional, cerca de 55\% das empresas são grandes e 18\% são médias.

A pesquisa de campo revelou, através das experiências compartilhadas pelas associações de aves e suínos visitadas, que o principal programa de desenvolvimento regional que fomentou a agroindústria na região foi o Fundo Constitucional de Financiamento do Centro-Oeste (FCO).

Criado pela Lei 7.827 de 27/09/89, o FCO vem exercendo importante papel na "promoção do crescimento econômico e do desenvolvimento social da região" (FCO, 2000, p.3). De acordo com informações do Banco do Brasil (FCO: Informações Gerenciais, 2000), órgão gestor deste fundo, foram gerados 214 mil empregos diretos e 297 mil empregos indiretos desde a sua criação até o final de 2000.

Segundo dados obtidos junto ao Banco do Brasil, desde 1989 até 2000 foram liberados R\$ 214 milhões do FCO para projetos de avicultura e suinocultura, contemplando 1335 operações. Especificamente em 2000, dos pouco mais de R\$288 milhões liberados pelo $\mathrm{FCO}$, quase $15 \%$ foram operações relacionadas à avicultura e à suinocultura, retratando a importância destes segmentos no volume total de recursos disponibilizado pelo fundo.

Dos estados que mais receberam recursos voltados para aves e suínos, Goiás apenas ultrapassou Mato Grosso do Sul no final da década de 90 graças a inúmeros projetos de Rio Verde-GO beneficiados pelo fundo a partir de 1998 (Figuras 22 e 23). 


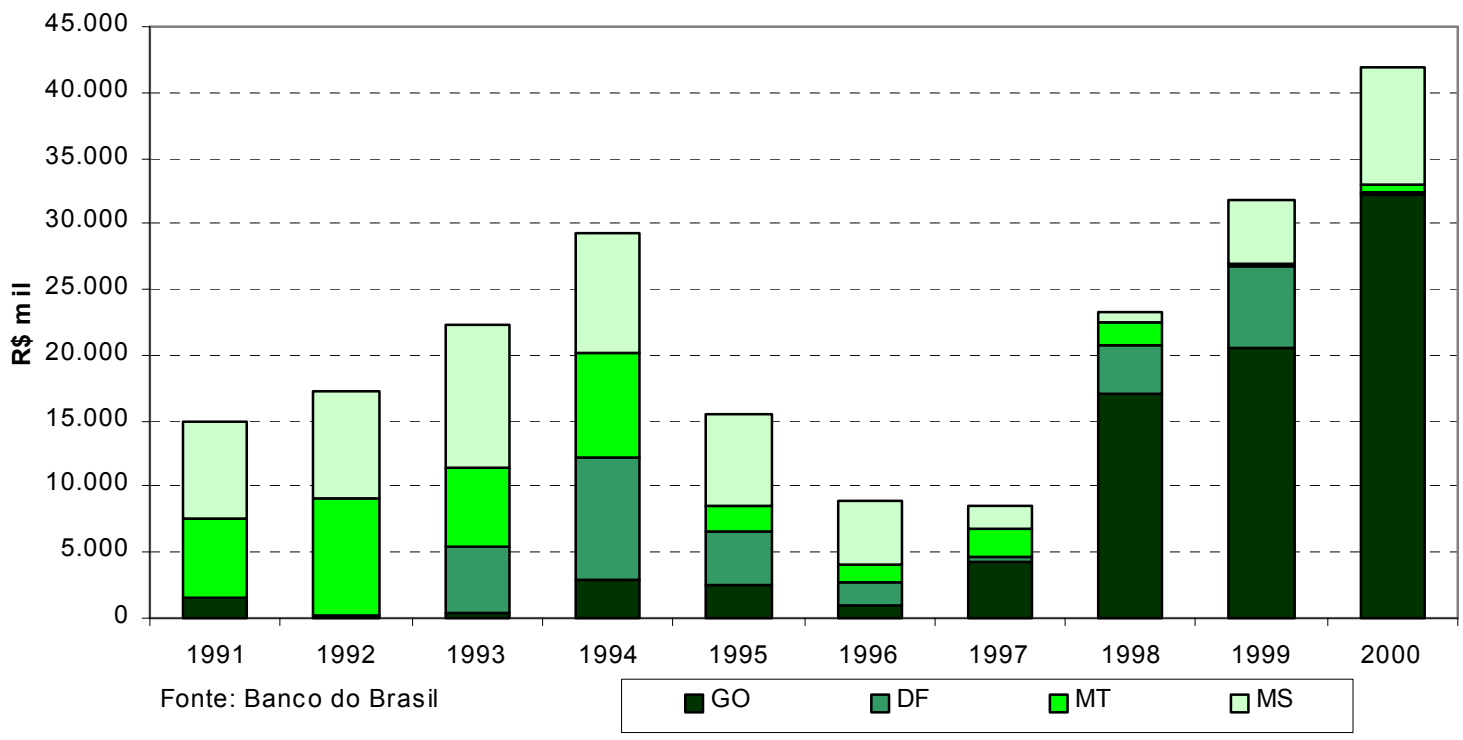

Figura 22 - Montante de recursos concedido pelo Fundo Constitucional de Financiamento do Centro-Oeste para projetos de avicultura e suinocultura, de 1991 a 2000, discriminado por estado

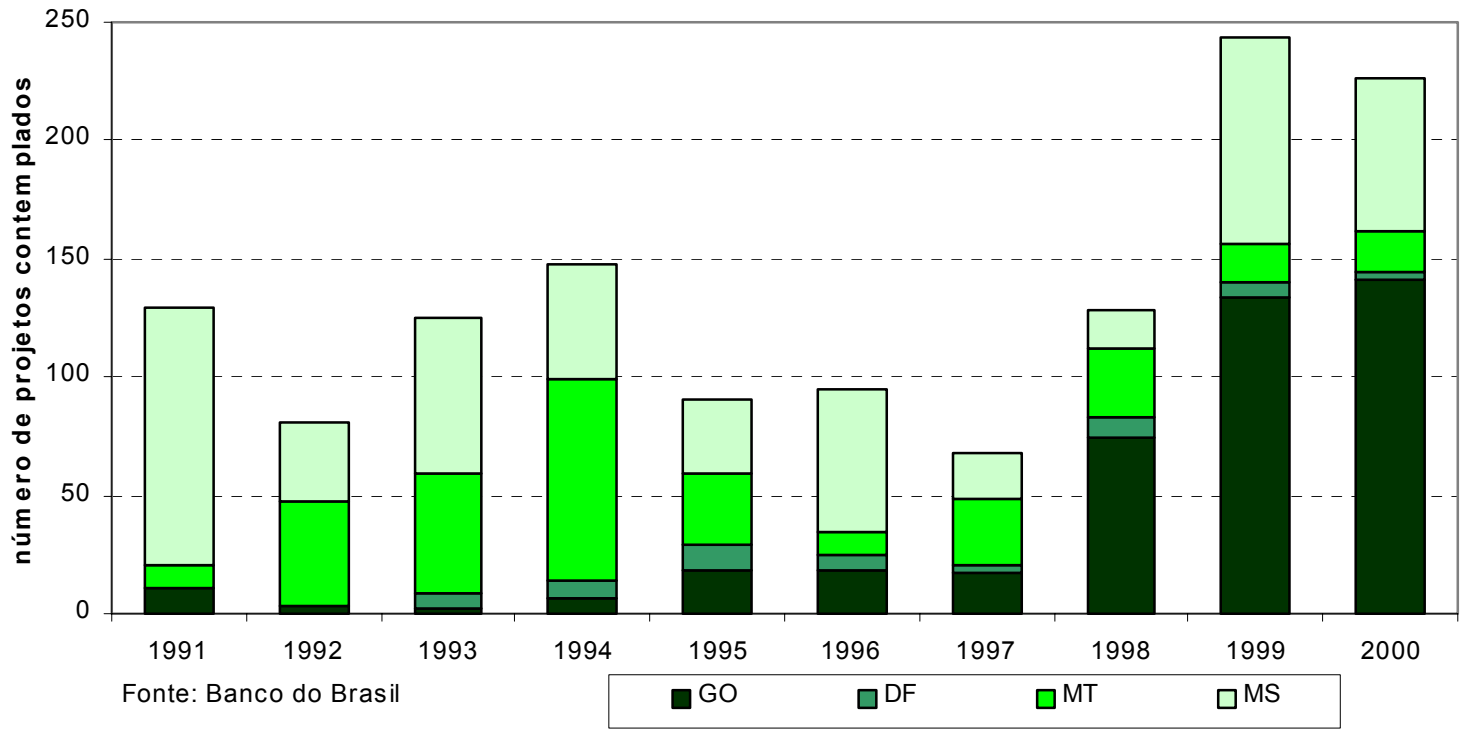

Figura 23 - Número de projetos de avicultura e suinocultura contemplados pelo Fundo Constitucional de Financiamento do Centro-Oeste, de 1991 a 2000, discriminado por estado

Pelo fato de a época coincidir com a instalação do projeto Buriti da Perdigão em Rio Verde-GO para abate de aves e suínos, acredita-se que significativo 
salto de recursos bem como de número de projetos contemplados após 98 em Goiás deveu-se justamente à atuação da empresa na captação de recursos para uso próprio e também como avalista de recursos para seus integrados.

De fato, a maioria das empresas de grande porte visitadas na pesquisa de campo manifestou intermediar operações do FCO para seus integrados, trabalhando não somente como avalista dos recursos como também administradora da parcela que é retida da receita de cada granja para amortização da dívida.

Não é à toa que tem havido grande procura pelos recursos do FCO. Os atrativos advêm dos relativamente baixos encargos financeiros ${ }^{39}$, do prazo de 12 anos para investimento fixo (incluindo 3 anos de carência) e disponibilidade de bônus de adimplência que pode chegar a $20 \%$ caso os pagamentos sejam feitos em dia e o histórico do devedor favorecer.

Assim, apesar de a pesquisa não revelar o fator programas de desenvolvimento regional como decisivo no local de escolha, uma vez que apenas $11 \%$ das empresas assim responderam, pode ser afirmado que, à semelhança do que foram os programas Polocentro e Prodecer para a agricultura dos cerrados, o FCO tem sido importante para a agroindústria da região, sobretudo no financiamento de granjeiros integrados a médios e grandes abatedouros que avalizam e supervisionam o crédito.

\subsubsection{Outros fatores}

Dos fatores que não se encaixavam em nenhum dos vetores locacionais definidos, proximidade dos mercados teve o quarto maior percentual $(66,7 \%)$ de atribuição importância grande e foi um dos fatores decisivos.

Apresentaram maior importância relativa a esse fator as empresas pequenas $(87,5 \%$ das pequenas classificaram a proximidade dos mercados como um

\footnotetext{
${ }^{39}$ A taxa fixa de juros para a modalidade mais utilizada para o financimaneto de atividades relacionadas à produção de aves e suínos, o FCO-Investimento Agropecuário, Programa de Desenvolvimento Rural, varia de $9 \%$ a.a. para mini produtores a $16 \%$ a.a. para grandes produtores.
} 
item importante na localização), as que são uma expansão regional $(77,8 \%)$, as de origem local $(83,3 \%)$ e as independentes $(100 \%)$.

Os fatores preferência individual do empresário e vínculo familiar na região tiveram que ser considerados pois se esperava que alguns projetos não teriam nenhuma explicação científica, mas somente o fato de o proprietário viver no local. Outros fatores seriam, então, desprezíveis. Os resultados destes fatores encontram-se na Tabela 17 no Anexo A.

Vale a pena ressaltar que preferência individual do empresário e vínculo familiar na região foram os fatores que apresentaram o maior percentual de respostas foi o fator individualmente causados da escolha, respectivamente 7,4\% e 11\%. Apenas outros dois fatores registraram este extrato de classificação, nível do custo do milho e boas condições para futuras expansões, porém ambos conseguindo apenas $3,7 \%$ como o fator individualmente causador da escolha. 


\section{CONCLUSÕES}

A pesquisa que visou estudar empiricamente o processo de decisão locacional bem como os fatores-chave na escolha do local produtivo das empresas dos complexos aves e suínos do Centro-Oeste, tendo como referencial teórico uma abordagem comportamental da Teoria da Localização, teve como principal constatação a grande importância que desempenha o fator milho não apenas na atração das empresas mas também como elemento naturalmente causador de atividades sinérgicas de agregação de valor a jusante da produção.

A pressuposição inicial deste estudo - antes mesmo dele ter sido estruturado -, que apregoava que os preços mais baratos das matérias-primas não seriam suficientes para explicar o desenvolvimento das atividades de avicultura e suinocultura no Centro-Oeste, teve que ser refutada basicamente pelo fato de os empresários haverem designado pouca importância aos outros vetores na escolha do local produtivo. Pode-se dizer, então que de fato é o fator milho que norteia a produção de aves e suínos no Centro-Oeste.

Porém, se de um lado é o vetor matérias-primas quem orienta a produção de aves e suínos, são os vetores infra-estrutura, programas de desenvolvimento regional e incentivos ficais que garantem a sustentação dos projetos e algumas vezes o seu sucesso.

Com relação ao processo decisório, pôde-se concluir que devido à grande variabilidade dos perfis das empresas, tornou-se complexa a definição de grupos homogêneos em quaisquer das características tamanho das firmas, status do negócio ou estrutura produtiva da empresa. Ou seja, todos os cruzamentos realizados entre estas 
características com as variáveis de decisão resultaram em testes de hipótese não significativos, forçando a não rejeição da hipótese de nulidade e, portanto, admitir a independência entre as variáveis. A existência de um grande número de empresas pequenas $(62,5 \%)$, empresas que se constituíam num novo negócio $(54,5 \%)$ ou empresas cujo negócio era uma expansão regional $(55,6 \%)$ classificadas como integradoras é a explicação para a independência constatada entre o esmero do estudo locacional e as variáveis característica tamanho, status e estrutura.

Todavia, o mesmo não ocorreu com a característica meta dos empresários, que conseguiu determinar um agrupamento prévio das empresas que as fizesse diferir em seu processo de decisão locacional. Sobremodo entre os grupos de empresas categorizadas com as metas minimizar custos de abastecimento de matériasprimas (principalmente milho) e apenas iniciar uma atividade produtiva como outra qualquer. Assim, seja a empresa grande ou integradora, o fato de ela ter explicitado não haver uma clara pretensão em estar iniciando, expandindo ou relocalizando sua atividade produtiva no Centro-Oeste, denotou a sua pequena preocupação com a localização.

Já as empresas que externaram seu principal objetivo de estar se dirigindo para o Centro-Oeste como sendo a minimização dos custos de abastecimento de milho, realizaram pesquisa mais primorosa, mais abrangente e geralmente de maior duração. Além de ratificar a grande importância para as variáveis de localização que abrangiam o vetor matérias-primas, a maioria desta classe de empresas (67\%) atribuiu importância para outras forças locacionais como boas condições para futuras expansões e incentivos estaduais. Este fato gera indícios de que aqueles que certamente buscavam grãos de menor custo, também se preocuparam em pesar e estudar outros fatores auxiliadores das decisões locacionais.

Em relação ao referencial teórico, a abordagem comportamentalista da Teoria da Localização permitiu que os objetivos essenciais da pesquisa pudessem ser atingidos com êxito, principalmente pelo fato de ser um instrumental flexível, possibilitando inclusive a obtenção de uma radiografia de um setor que está em franca expansão no Centro-Oeste. 
Mais do que conhecer os porquês das empresas de aves e suínos estarem procurando o Centro-Oeste para produzir, o método empregado via aplicação de questionários possibilitou conhecer melhor quem são as empresas e as pessoas que estão por detrás destes estratégicos agronegócios. Ressalta-se, ainda, que a visita a algumas empresas bem como associações de aves e suínos do Centro-Oeste foi reveladora de particularidades não captadas no método de pesquisa conduzido, sendo assim, sempre louvável a realização de viagens de pesquisa de campo em trabalhos desta natureza.

Entretanto, se de um lado o referencial teórico e o método empregado na pesquisa foram satisfatórios para a condução de um trabalho empírico, por outro faltou a parte quantitativa para dimensionar as forças locacionais e gerar resultados mais contundentes e menos exploratórios.

Os principais pontos fracos do método de questionário empregado estão relacionados a total subjetividade do respondente. Além disso, mesmo quando se trabalha com um universo pequeno de empresas, o esforço para o envio e cobrança do retorno dos questionários torna-se desgastante. Admite-se que o ideal para este tipo de estudo seria a realização de entrevistas individuais, pois além de se trabalhar com o universo total das empresas, estar-se-ia salvaguardando uma melhor qualidade das respostas.

Como principais dificuldades deparadas na trajetória deste estudo destacam-se: grande dificuldade de obtenção da listagem completa das empresas de aves e suínos da região devido à falta de organismos competentes para a organização e atualização das informações em todos os estados do Centro-Oeste; dificuldade de interpretação dos questionários por parte de alguns pequenos produtores aliada à falta de vontade de responder de outros; o grande esforço feito para se maximizar a taxa de retorno dos questionários.

Em suma, pode-se dizer que ficou confirmado neste trabalho o forte apelo para que os modelos e ou abordagens sobre a localização agroindustrial, em especial àquelas ligadas aos segmentos grãos-carne, contemplem com bastante abrangência os fatores tidos como clássicos da localização, como a proximidade às fontes de matériasprimas e mão-de-obra. Enaltece-se, assim, a importância dos modelos tidos como 
clássicos na localização industrial como balizadores de todo e qualquer trabalho que venha a ser desenvolvido nesta área.

Deixa-se, finalmente, como sugestão para futuros trabalhos relacionados com a dinâmica locacional da avicultura e suinocultura em regiões de fronteira, um estudo mais quantitativo da produção, avaliando o potencial de crescimento destes segmentos em regiões fora do eixo tradicional de produção Sul-Sudeste. Como os resultados deste trabalho mostraram a grande importância que fatores clássicos da localização industrial desempenharam na atração e na escolha pelo sítio produtivo, seria conveniente o desenvolvimento de trabalhos que visem determinar locais ótimos de produção, através de modelos adaptados dos tradicionais da localização. Outra sugestão seria a elaboração de trabalhos que pesquisem a sustentabilidade deste movimento recente de produção de carnes no Centro-Oeste, buscando alternativas, potencialidades e prosperidade para a produção dos sistemas agroindustriais bem como o desenvolvimento econômico de regiões de fronteira. 
ANEXOS 


\section{ANEXO A}

Neste anexo estão contidas as Tabelas 10, 11, 12, 13, 14, 15, 16 e 17 
Tabela 10. Evolução da área, rendimento e produção da soja das regiões Norte/Nordeste, Sul, Sudeste e CentroOeste, de 79/80 a 00/01

\begin{tabular}{|c|c|c|c|c|c|c|c|c|c|c|c|c|c|c|c|}
\hline \multirow[b]{2}{*}{$\begin{array}{l}\text { Ano- } \\
\text { safra }\end{array}$} & \multicolumn{3}{|c|}{$\mathrm{N} / \mathrm{NE}$} & \multicolumn{3}{|c|}{ SUDESTE } & \multicolumn{3}{|c|}{ SUL } & \multicolumn{3}{|c|}{ C-OESTE } & \multicolumn{3}{|c|}{ BRASIL } \\
\hline & $\begin{array}{l}\text { Área } \\
10^{6} \text { ha }\end{array}$ & $\begin{array}{c}\text { Rend. } \\
\text { t/ha }\end{array}$ & $\begin{array}{l}\text { Prod. } \\
10^{6} t\end{array}$ & $\begin{array}{l}\text { Área } \\
10^{6} \text { ha }\end{array}$ & $\begin{array}{c}\text { Rend. } \\
\text { t/ha }\end{array}$ & $\begin{array}{l}\text { Prod. } \\
10^{6} t\end{array}$ & $\begin{array}{l}\text { Área } \\
10^{6} \text { ha }\end{array}$ & $\begin{array}{c}\text { Rend. } \\
\text { t/ha }\end{array}$ & $\begin{array}{l}\text { Prod. } \\
10^{6} t\end{array}$ & $\begin{array}{l}\text { Área } \\
10^{6} \text { ha }\end{array}$ & $\begin{array}{c}\text { Rend. } \\
\text { t/ha }\end{array}$ & $\begin{array}{l}\text { Prod. } \\
10^{6} t\end{array}$ & $\begin{array}{l}\text { Área } \\
10^{6} \text { ha }\end{array}$ & $\begin{array}{c}\text { Rend. } \\
\text { t/ha }\end{array}$ & $\begin{array}{l}\text { Prod. } \\
10^{6} t\end{array}$ \\
\hline $79 / 80$ & 0,00 & 1,16 & 0,00 & 0,71 & 1,84 & 1,31 & 6,93 & 1,69 & 11,73 & 1,12 & 1,66 & 1,85 & 8,76 & 1,70 & 14,89 \\
\hline $80 / 81$ & 0,00 & 1,58 & 0,00 & 0,73 & 1,80 & 1,32 & 6,71 & 1,80 & 12,07 & 1,25 & 1,68 & 2,10 & 8,69 & 1,78 & 15,48 \\
\hline $81 / 82$ & 0,00 & 0,33 & 0,00 & 0,74 & 1,86 & 1,38 & 6,28 & 1,44 & 9,07 & 1,36 & 1,79 & 2,44 & 8,39 & 1,54 & 12,89 \\
\hline $82 / 83$ & 0,01 & 0,90 & 0,00 & 0,73 & 1,96 & 1,43 & 6,03 & 1,65 & 9,96 & 1,65 & 1,90 & 3,14 & 8,41 & 1,73 & 14,53 \\
\hline $83 / 84$ & 0,03 & 1,30 & 0,04 & 0,79 & 1,72 & 1,36 & 6,20 & 1,63 & 10,12 & 2,14 & 1,79 & 3,83 & 9,16 & 1,67 & 15,34 \\
\hline $84 / 85$ & 0,07 & 1,16 & 0,08 & 0,93 & 1,96 & 1,82 & 6,24 & 1,72 & 10,74 & 2,84 & 1,96 & 5,57 & 10,07 & 1,81 & 18,21 \\
\hline $85 / 86$ & 0,12 & 1,32 & 0,16 & 0,91 & 1,86 & 1,69 & 5,81 & 1,09 & 6,34 & 2,81 & 1,79 & 5,03 & 9,64 & 1,37 & 13,21 \\
\hline $86 / 87$ & 0,18 & 0,87 & 0,16 & 0,88 & 1,97 & 1,72 & 5,30 & 1,77 & 9,38 & 2,87 & 2,03 & 5,81 & 9,22 & 1,85 & 17,07 \\
\hline $87 / 88$ & 0,28 & 2,37 & 0,43 & 1,01 & 2,26 & 1,99 & 6,04 & 1,69 & 8,97 & 3,38 & 2,35 & 6,74 & 10,71 & 1,97 & 18,13 \\
\hline $88 / 89$ & 0,48 & 1,60 & 0,77 & 1,19 & 2,15 & 2,56 & 6,52 & 1,83 & 11,95 & 4,05 & 2,13 & 8,65 & 12,25 & 1,95 & 23,93 \\
\hline $89 / 90$ & 0,43 & 0,75 & 0,32 & 1,17 & 1,58 & 1,84 & 6,25 & 1,86 & 11,61 & 3,71 & 1,71 & 6,33 & 11,55 & 1,74 & 20,10 \\
\hline $90 / 91$ & 0,29 & 1,99 & 0,58 & 0,97 & 1,99 & 1,93 & 5,54 & 1,12 & 6,22 & 2,95 & 2,26 & 6,67 & 9,74 & 1,58 & 15,39 \\
\hline $91 / 92$ & 0,36 & 1,49 & 0,54 & 0,92 & 2,08 & 1,91 & 5,02 & 1,92 & 9,66 & 3,28 & 2,23 & 7,31 & 9,58 & 2,03 & 19,42 \\
\hline $92 / 93$ & 0,44 & 1,62 & 0,72 & 1,08 & 2,13 & 2,31 & 5,38 & 2,14 & 11,53 & 3,81 & 2,23 & 8,48 & 10,72 & 2,15 & 23,04 \\
\hline $93 / 94$ & 0,53 & 2,02 & 1,08 & 1,18 & 2,13 & 2,50 & 5,55 & 2,09 & 11,58 & 4,24 & 2,33 & 9,91 & 11,50 & 2,18 & 25,06 \\
\hline $94 / 95$ & 0,60 & 2,20 & 1,31 & 1,16 & 2,03 & 2,37 & 5,36 & 2,27 & 12,17 & 4,56 & 2,21 & 10,08 & 11,68 & 2,22 & 25,93 \\
\hline $95 / 96$ & 0,54 & 1,74 & 0,94 & 1,09 & 2,08 & 2,27 & 5,34 & 2,09 & 11,13 & 3,69 & 2,39 & 8,85 & 10,66 & 2,17 & 23,19 \\
\hline $96 / 97$ & 0,62 & 2,15 & 1,33 & 1,10 & 2,28 & 2,50 & 5,68 & 2,09 & 11,89 & 3,98 & 2,62 & 10,44 & 11,38 & 2,30 & 26,16 \\
\hline $97 / 98$ & 0,77 & 2,14 & 1,66 & 1,13 & 2,21 & 2,50 & 6,19 & 2,31 & 14,32 & 5,06 & 2,55 & 12,89 & 13,16 & 2,38 & 31,36 \\
\hline 98/99 & 0,82 & 2,10 & 1,72 & 1,10 & 2,51 & 2,76 & 6,12 & 2,11 & 12,92 & 4,96 & 2,70 & 13,36 & 12,99 & 2,37 & 30,75 \\
\hline $99 / 00$ & 0,91 & 2,43 & 2,21 & 1,15 & 2,23 & 2,57 & 6,05 & 2,09 & 12,61 & 5,39 & 2,77 & 14,95 & 13,51 & 2,40 & 32,34 \\
\hline $00 / 01^{*}$ & 1,02 & 2,34 & 2,39 & 1,15 & 2,30 & 2,64 & 5,90 & 2,51 & 14,83 & 5,57 & 2,89 & 16,11 & 13,64 & 2,64 & 35,97 \\
\hline
\end{tabular}

Fonte: CONAB/DIDEM

* Dados preliminares 
Tabela 11. Evolução da área, rendimento e produção do milho ( $1^{\mathrm{a}}$ safra $)$ das regiões Norte/Nordeste, Sul, Sudeste e Centro-Oeste, de 79/80 a 00/01

\begin{tabular}{|c|c|c|c|c|c|c|c|c|c|c|c|c|c|c|c|}
\hline \multirow[b]{2}{*}{$\begin{array}{l}\text { Ano- } \\
\text { safra }\end{array}$} & \multicolumn{3}{|c|}{ N/NE } & \multicolumn{3}{|c|}{ SUDESTE } & \multicolumn{3}{|c|}{ SUL } & \multicolumn{3}{|c|}{ C-OESTE } & \multicolumn{3}{|c|}{ BRASIL } \\
\hline & $\begin{array}{l}\text { Área } \\
10^{\circ} \text { ha }\end{array}$ & $\begin{array}{c}\text { Rend. } \\
\text { t/ha }\end{array}$ & $\begin{array}{l}\text { Prod. } \\
10^{\circ} t\end{array}$ & $\begin{array}{l}\text { Área } \\
10^{\circ} \text { ha }\end{array}$ & $\begin{array}{c}\text { Rend. } \\
\text { t/ha }\end{array}$ & $\begin{array}{l}\text { Prod. } \\
10^{\circ} t\end{array}$ & $\begin{array}{l}\text { Área } \\
10^{\circ} \text { ha }\end{array}$ & $\begin{array}{c}\text { Rend. } \\
\text { t/ha }\end{array}$ & $\begin{array}{l}\text { Prod. } \\
10^{\circ} t\end{array}$ & $\begin{array}{l}\text { Área } \\
10^{\circ} \text { ha }\end{array}$ & $\begin{array}{c}\text { Rend. } \\
\text { t/ha }\end{array}$ & $\begin{array}{l}\text { Prod. } \\
10^{\circ} t\end{array}$ & $\begin{array}{l}\text { Área } \\
10^{\circ} \text { ha }\end{array}$ & $\begin{array}{c}\text { Rend. } \\
\text { t/ha }\end{array}$ & $\begin{array}{l}\text { Prod. } \\
10^{\circ} t\end{array}$ \\
\hline $79 / 80$ & 2,81 & 0,39 & 1,09 & 2,73 & 2,02 & 5,51 & 4,98 & 2,14 & 10,68 & 1,00 & 2,07 & 2,08 & 11,52 & 1,68 & 19,36 \\
\hline $80 / 81$ & 2,94 & 0,26 & 0,76 & 2,94 & 2,05 & 6,03 & 4,92 & 2,49 & 12,28 & 1,10 & 1,90 & 2,09 & 11,90 & 1,78 & 21,16 \\
\hline $81 / 82$ & 3,03 & 0,45 & 1,35 & 3,15 & 2,14 & 6,74 & 5,16 & 2,12 & 10,94 & 1,19 & 2,06 & 2,46 & 12,54 & 1,71 & 21,49 \\
\hline $82 / 83$ & 2,62 & 0,19 & 0,49 & 2,79 & 2,18 & 6,08 & 5,01 & 2,00 & 10,01 & 1,14 & 2,10 & 2,40 & 11,55 & 1,64 & 18,98 \\
\hline $83 / 84$ & 2,59 & 0,67 & 1,73 & 2,95 & 1,95 & 5,74 & 5,15 & 2,17 & 11,17 & 1,19 & 1,81 & 2,16 & 11,88 & 1,75 & 20,80 \\
\hline $84 / 85$ & 2,77 & 0,58 & 1,60 & 2,83 & 2,19 & 6,20 & 4,83 & 2,18 & 10,50 & 1,14 & 2,10 & 2,39 & 11,57 & 1,79 & 20,69 \\
\hline $85 / 86$ & 3,18 & 0,65 & 2,06 & 3,01 & 2,24 & 6,73 & 5,00 & 1,57 & 7,83 & 1,44 & 2,18 & 3,14 & 12,62 & 1,56 & 19,75 \\
\hline $86 / 87$ & 3,41 & 0,30 & 1,01 & 3,22 & 2,29 & 7,39 & 5,67 & 2,35 & 13,33 & 1,76 & 2,52 & 4,45 & 14,06 & 1,86 & 26,18 \\
\hline $87 / 88$ & 3,54 & 0,69 & 2,43 & 2,90 & 2,51 & 7,30 & 4,80 & 2,20 & 10,58 & 1,64 & 2,73 & 4,47 & 12,89 & 1,92 & 24,78 \\
\hline $88 / 89$ & 3,32 & 0,71 & 2,36 & 2,88 & 2,55 & 7,37 & 4,43 & 2,45 & 10,82 & 1,68 & 3,04 & 5,10 & 12,31 & 2,08 & 25,65 \\
\hline $89 / 90$ & 2,75 & 0,52 & 1,43 & 2,75 & 2,01 & 5,51 & 4,53 & 2,53 & 11,49 & 1,54 & 2,16 & 3,33 & 11,57 & 1,88 & 21,76 \\
\hline $90 / 91$ & 3,13 & 0,80 & 2,52 & 2,94 & 2,62 & 7,72 & 5,06 & 1,66 & 8,37 & 1,52 & 2,92 & 4,43 & 12,65 & 1,82 & 23,04 \\
\hline $91 / 92$ & 3,24 & 0,55 & 1,77 & 3,01 & 2,56 & 7,72 & 5,37 & 2,86 & 15,35 & 1,41 & 3,12 & 4,40 & 13,04 & 2,24 & 29,24 \\
\hline $92 / 93$ & 2,53 & 0,50 & 1,27 & 2,73 & 2,71 & 7,40 & 4,74 & 3,01 & 14,26 & 1,17 & 3,32 & 3,87 & 11,15 & 2,40 & 26,81 \\
\hline $93 / 94$ & 3,59 & 0,93 & 3,33 & 2,58 & 2,73 & 7,05 & 4,92 & 3,19 & 15,71 & 1,31 & 3,69 & 4,83 & 12,40 & 2,49 & 30,92 \\
\hline $94 / 95$ & 3,63 & 0,96 & 3,47 & 2,52 & 2,99 & 7,56 & 5,10 & 3,44 & 17,55 & 1,37 & 3,95 & 5,41 & 12,61 & 2,69 & 33,99 \\
\hline $95 / 96$ & 3,71 & 0,99 & 3,67 & 2,28 & 3,01 & 6,87 & 4,64 & 2,74 & 12,71 & 1,40 & 4,03 & 5,65 & 12,04 & 2,40 & 28,90 \\
\hline $96 / 97$ & 3,42 & 0,97 & 3,31 & 2,30 & 3,35 & 7,69 & 4,53 & 3,31 & 14,99 & 1,36 & 4,20 & 5,71 & 11,60 & 2,73 & 31,70 \\
\hline $97 / 98$ & 2,45 & 0,86 & 2,11 & 2,11 & 3,19 & 6,74 & 3,73 & 3,38 & 12,59 & 0,78 & 4,05 & 3,16 & 9,07 & 2,71 & 24,61 \\
\hline $98 / 99$ & 2,82 & 1,16 & 3,27 & 2,15 & 3,28 & 7,06 & 3,79 & 3,13 & 11,89 & 1,02 & 4,46 & 4,55 & 9,79 & 2,73 & 26,77 \\
\hline $99 / 00$ & 2,94 & 1,27 & 3,75 & 2,03 & 3,37 & 6,83 & 3,91 & 3,29 & 12,86 & 0,97 & 4,43 & 4,28 & 9,84 & 2,82 & 27,72 \\
\hline $00 / 01^{*}$ & 2,95 & 1,28 & 3,76 & 2,28 & 3,20 & 7,28 & 4,34 & 4,19 & 18,19 & 1,25 & 4,25 & 5,33 & 10,82 & 3,20 & 34,57 \\
\hline
\end{tabular}

Fonte: CONAB/DIDEM

* Dados preliminares 
Tabela 12. Evolução da área, rendimento e produção do milho ( $2^{\mathrm{a}}$ safra $)$ das regiões Norte/Nordeste, Sul, Sudeste e Centro-Oeste, de 88/89 a 00/01

\begin{tabular}{|c|c|c|c|c|c|c|c|c|c|c|c|c|c|c|c|}
\hline \multirow{2}{*}{$\begin{array}{l}\text { Ano- } \\
\text { safra }\end{array}$} & \multicolumn{3}{|c|}{ N/NE } & \multicolumn{3}{|c|}{ SUDESTE } & \multicolumn{3}{|c|}{ SUL } & \multicolumn{3}{|c|}{ C-OESTE } & \multicolumn{3}{|c|}{ BRASIL } \\
\hline & $\begin{array}{c}\text { Área } \\
10^{6} \text { ha }\end{array}$ & $\begin{array}{c}\text { Rend. } \\
\text { t/ha }\end{array}$ & $\begin{array}{l}\text { Prod. } \\
10^{6} t\end{array}$ & $\begin{array}{l}\text { Área } \\
10^{6} \text { ha }\end{array}$ & $\begin{array}{c}\text { Rend. } \\
\text { t/ha }\end{array}$ & $\begin{array}{l}\text { Prod. } \\
10^{6} t\end{array}$ & $\begin{array}{c}\text { Área } \\
10^{6} \text { ha }\end{array}$ & $\begin{array}{c}\text { Rend. } \\
\text { t/ha }\end{array}$ & $\begin{array}{l}\text { Prod. } \\
10^{6} t\end{array}$ & $\begin{array}{c}\text { Área } \\
10^{6} \text { ha }\end{array}$ & $\begin{array}{c}\text { Rend. } \\
\text { t/ha }\end{array}$ & $\begin{array}{l}\text { Prod. } \\
10^{6} t\end{array}$ & $\begin{array}{c}\text { Área } \\
10^{6} \text { ha }\end{array}$ & $\begin{array}{c}\text { Rend. } \\
\text { t/ha }\end{array}$ & $\begin{array}{l}\text { Prod. } \\
10^{6} t\end{array}$ \\
\hline $88 / 89$ & 0,32 & 0,59 & 0,19 & 0,10 & 1,25 & 0,13 & 0,25 & 1,25 & 0,31 & - & - & - & 0,67 & 0,93 & 0,62 \\
\hline $89 / 90$ & 0,26 & 0,19 & 0,05 & 0,07 & 2,20 & 0,14 & 0,19 & 1,60 & 0,30 & 0,01 & 1,89 & 0,01 & 0,52 & 0,97 & 0,50 \\
\hline $90 / 91$ & 0,30 & 0,45 & 0,13 & 0,23 & 2,11 & 0,48 & 0,23 & 1,58 & 0,37 & 0,05 & 1,70 & 0,08 & 0,80 & 1,32 & 1,06 \\
\hline $91 / 92$ & 0,30 & 0,30 & 0,09 & 0,28 & 2,11 & 0,60 & 0,30 & 2,17 & 0,66 & 0,11 & 1,70 & 0,18 & 0,99 & 1,54 & 1,53 \\
\hline $92 / 93$ & 0,09 & 0,15 & 0,01 & 0,37 & 2,40 & 0,88 & 0,55 & 2,06 & 1,14 & 0,28 & 1,36 & 0,37 & 1,28 & 1,87 & 2,40 \\
\hline $93 / 94$ & 0,11 & 0,83 & 0,09 & 0,37 & 1,47 & 0,55 & 0,70 & 1,03 & 0,72 & 0,57 & 1,56 & 0,89 & 1,75 & 1,28 & 2,25 \\
\hline $94 / 95$ & 0,21 & 0,83 & 0,18 & 0,37 & 2,32 & 0,86 & 0,60 & 2,40 & 1,45 & 0,48 & 2,01 & 0,97 & 1,67 & 2,07 & 3,45 \\
\hline $95 / 96$ & 0,21 & 1,12 & 0,24 & 0,37 & 2,10 & 0,78 & 0,57 & 2,40 & 1,37 & 0,56 & 1,98 & 1,12 & 1,72 & 2,04 & 3,51 \\
\hline $96 / 97$ & 0,31 & 0,76 & 0,24 & 0,40 & 1,94 & 0,78 & 0,67 & 1,40 & 0,94 & 0,82 & 2,52 & 2,06 & 2,20 & 1,82 & 4,01 \\
\hline $97 / 98$ & 0,21 & 0,61 & 0,13 & 0,44 & 2,85 & 1,25 & 0,79 & 2,52 & 2,00 & 0,88 & 2,50 & 2,21 & 2,32 & 2,41 & 5,58 \\
\hline $98 / 99$ & 0,32 & 0,90 & 0,29 & 0,47 & 2,07 & 0,96 & 1,01 & 2,50 & 2,52 & 0,88 & 1,94 & 1,70 & 2,67 & 2,05 & 5,47 \\
\hline $99 / 00$ & 0,30 & 0,84 & 0,26 & 0,47 & 0,78 & 0,36 & 1,12 & 1,07 & 1,20 & 1,01 & 2,08 & 2,10 & 2,91 & 1,35 & 3,93 \\
\hline $00 / 01^{*}$ & 0,30 & 0,85 & 0,26 & 0,47 & 1,95 & 0,91 & 1,12 & 1,98 & 2,23 & 1,01 & 2,21 & 2,23 & 2,91 & 1,93 & 5,62 \\
\hline
\end{tabular}

Fonte: CONAB/DIDEM

* Dados preliminares, considerando rendimento médio dos últimos 5 períodos 
Tabela 13. Resultados das variáveis característica, cruzadas uma a uma. Dados em valores percentuais, onde as frequências dos cruzamentos de cada par de categoria foram calculadas na direção das linhas

\begin{tabular}{|c|c|c|c|c|c|c|c|c|c|c|c|c|c|c|c|c|c|c|c|c|c|}
\hline \multirow{2}{*}{ Caract. } & \multicolumn{4}{|c|}{ Época } & \multicolumn{3}{|c|}{ Tamanho } & \multicolumn{3}{|c|}{ Status } & \multicolumn{3}{|c|}{ Origem } & \multicolumn{3}{|c|}{ Estrutura } & \multicolumn{4}{|c|}{ Meta } & \multirow{2}{*}{$\begin{array}{c}\text { Total } \\
\text { Marginal }\end{array}$} \\
\hline & até 80 & $81-90$ & $91-95$ & $96-00$ & peq. & médi & grande & novo & exp. reg & exp. CO & local & C.O. & migr. & ind. & inte. & com. & tend & $\operatorname{mir}$ & nerc & nda. & \\
\hline \multicolumn{22}{|l|}{ Época } \\
\hline até 80 & & & & & 33,3 & 33,3 & 33,3 & 0,0 & 100,0 & 0,0 & 0,0 & 33,3 & 66,7 & 33,3 & 33,3 & 33,3 & 0,0 & 0,0 & 33,3 & 66,7 & 11,1 \\
\hline $81-90$ & & & & & 50,0 & 50,0 & 0,0 & 75,0 & 25,0 & 0,0 & 50,0 & 0,0 & 50,0 & 25,0 & 50,0 & 25,0 & 0,0 & 0,0 & 0,0 & 100,0 & 14,8 \\
\hline $91-95$ & & & & & 36,4 & 18,2 & 45,5 & 27,3 & 27,3 & 45,5 & 54,5 & 0,0 & 45,5 & 9,1 & 81,8 & 9,1 & 18,2 & 54,5 & 0,0 & 27,3 & 40,7 \\
\hline $96-00$ & & & & & 11,1 & 33,3 & 55,6 & 55,6 & 22,2 & 22,2 & 44,4 & 0,0 & 55,6 & 0,0 & 66,7 & 33,3 & 11,1 & 33,3 & 33,3 & 22,2 & 33,3 \\
\hline \multicolumn{22}{|l|}{ Tamanho } \\
\hline pequena & 12,5 & 25,0 & 50,0 & 12,5 & & & & 50,0 & 50,0 & 0,0 & 62,5 & 12,5 & 25,0 & 25,0 & 62,5 & 12,5 & 12,5 & 0,0 & 12,5 & 75,0 & 29,6 \\
\hline média & 12,5 & 25,0 & 25,0 & 37,5 & & & & 62,5 & 37,5 & 0,0 & 37,5 & 0,0 & 62,5 & 12,5 & 37,5 & 50,0 & 12,5 & 12,5 & 37,5 & 37,5 & 29,6 \\
\hline $\begin{array}{l}\text { grande } \\
\text { Status }\end{array}$ & 9,1 & 0,0 & \multicolumn{12}{|c|}{ Status } & 90,9 & 9,1 & 9,1 & 72,7 & 0,0 & 18,2 & 40,7 \\
\hline novo & 0,0 & 27,3 & 27,3 & 45,5 & 36,4 & 45,5 & 18,2 & & & & 54,5 & 0,0 & 45,5 & 0,0 & 54,5 & 45,5 & 9,1 & 27,3 & 27,3 & 36,4 & 40,7 \\
\hline exp. reg & 33,3 & 11,1 & 33,3 & 22,2 & 44,4 & 33,3 & 22,2 & & & & 55,6 & 11,1 & 33,3 & 33,3 & 55,6 & 11,1 & 11,1 & 0,0 & 11,1 & 77,8 & 33,3 \\
\hline exp. CO & 0,0 & 0,0 & 71,4 & 28,6 & 0,0 & 0,0 & 100,0 & & & & 14,3 & 0,0 & 85,7 & 0,0 & 100,0 & 0,0 & 14,3 & 85,7 & 0,0 & 0,0 & 25,9 \\
\hline \multicolumn{22}{|l|}{ Origem } \\
\hline local & 0,0 & 16,7 & 50,0 & 33,3 & 41,7 & 25,0 & 33,3 & 50,0 & 41,7 & 8,3 & & & & 8,3 & 75,0 & 16,7 & 16,7 & 33,3 & 0,0 & 50,0 & 44,4 \\
\hline C.O. & 100,0 & 0,0 & 0,0 & 0,0 & 100,0 & 0,0 & 0,0 & 0,0 & 100,0 & 0,0 & & & & 100,0 & 0,0 & 0,0 & 0,0 & 0,0 & 0,0 & 100,0 & 3,7 \\
\hline migração & 14,3 & 14,3 & 35,7 & 35,7 & 14,3 & 35,7 & 50,0 & 35,7 & 21,4 & 42,9 & & & & 7,1 & 64,3 & 28,6 & 7,1 & 35,7 & 28,6 & 28,6 & 51,9 \\
\hline \multicolumn{22}{|l|}{ Estrutura } \\
\hline indep. & 33,3 & 33,3 & 33,3 & 0,0 & 66,7 & 33,3 & 0,0 & 0,0 & 100,0 & 0,0 & 33,3 & 33,3 & 33,3 & & & & 0,0 & 0,0 & 0,0 & 100,0 & 11,1 \\
\hline integrada & 5,6 & 11,1 & 50,0 & 33,3 & 27,8 & 16,7 & 55,6 & 33,3 & 27,8 & 38,9 & 50,0 & 0,0 & 50,0 & & & & 11,1 & 44,4 & 5,6 & 38,9 & 66,7 \\
\hline comercial & 16,7 & 16,7 & 16,7 & 50,0 & 16,7 & 66,7 & 16,7 & 83,3 & 16,7 & 0,0 & 33,3 & 0,0 & 66,7 & & & & 16,7 & 16,7 & 50,0 & 16,7 & 22,2 \\
\hline \multicolumn{22}{|l|}{ Meta } \\
\hline tend. & 0,0 & 0,0 & 66,7 & 33,3 & 33,3 & 33,3 & 33,3 & 33,3 & 33,3 & 33,3 & 66,7 & 0,0 & 33,3 & 0,0 & 66,7 & 33,3 & & & & & 11,1 \\
\hline $\min$. & 0,0 & 0,0 & 66,7 & 33,3 & 0,0 & 11,1 & 88,9 & 33,3 & 0,0 & 66,7 & 44,4 & 0,0 & 55,6 & 0,0 & 88,9 & 11,1 & & & & & 33,3 \\
\hline merc. & 25,0 & 0,0 & 0,0 & 75,0 & 25,0 & 75,0 & 0,0 & 75,0 & 25,0 & 0,0 & 0,0 & 0,0 & 100,0 & 0,0 & 25,0 & 75,0 & & & & & 14,8 \\
\hline nda. & 18,2 & 36,4 & 27,3 & 18,2 & 54,5 & 27,3 & 18,2 & 36,4 & 63,6 & 0,0 & 54,5 & 9,1 & 36,4 & 27,3 & 63,6 & 9,1 & & & & & 40,7 \\
\hline
\end{tabular}

Fonte: Dados da pesquisa 
Tabela 14. Resultados dos cruzamentos das variáveis característica com as de decisão locacional (em valores percentuais). (a) frequências calculadas na direção das colunas; (b) frequências calculadas na direção das linhas

\begin{tabular}{|c|c|c|c|c|c|c|c|c|c|c|c|c|c|c|c|c|c|c|}
\hline \multicolumn{19}{|c|}{ a - Frequências calculadas na COLUNA } \\
\hline \multirow{2}{*}{\multicolumn{2}{|c|}{ Características }} & Variáveis & \multicolumn{4}{|c|}{ Amplitude } & \multicolumn{4}{|c|}{ Duração } & \multicolumn{3}{|c|}{ Última } & \multicolumn{2}{|c|}{ Perfil } & \multicolumn{3}{|c|}{ Intensidade } \\
\hline & & Decisão & estado & c.O. & todas & não & não & $6-12$ & $6-12$ & + de 12 & SIM & NÃO & não fez & SIM & NÃO & peq. & média & grande \\
\hline & & Total Marginal & 29,6 & 11,1 & 29,6 & 29,6 & 29,6 & 14,8 & 18,5 & 37,0 & 14,8 & 51,9 & 33,3 & 44,4 & 55,6 & 29,6 & 40,7 & 29,6 \\
\hline \multirow{3}{*}{ Tamanho } & pequena & 29,6 & 50,0 & 0,0 & 0,0 & 50,0 & 37,5 & 50,0 & 40,0 & 10,0 & 0,0 & 28,6 & 44,4 & 33,3 & 26,7 & 37,5 & 27,3 & 25,0 \\
\hline & média & 29,6 & 25,0 & 33,3 & 25,0 & 37,5 & 50,0 & 25,0 & 20,0 & 20,0 & 75,0 & 7,1 & 44,4 & 16,7 & 40,0 & 50,0 & 27,3 & 12,5 \\
\hline & grande & 40,7 & 25,0 & 66,7 & 75,0 & 12,5 & 12,5 & 25,0 & 40,0 & 70,0 & 25,0 & 64,3 & 11,1 & 50,0 & 33,3 & 12,5 & 45,5 & 62,5 \\
\hline \multirow{3}{*}{ Status } & novo & 40,7 & 12,5 & 66,7 & 37,5 & 62,5 & 50,0 & 50,0 & 40,0 & 30,0 & 75,0 & 21,4 & 55,6 & 33,3 & 46,7 & 50,0 & 36,4 & 37,5 \\
\hline & exp. reg & 33,3 & 75,0 & 0,0 & 0,0 & 37,5 & 50,0 & 25,0 & 40,0 & 20,0 & 0,0 & 35,7 & 44,4 & 33,3 & 33,3 & 50,0 & 27,3 & 25,0 \\
\hline & exp. CO & 25,9 & 12,5 & 33,3 & 62,5 & 0,0 & 0,0 & 25,0 & 20,0 & 50,0 & 25,0 & 42,9 & 0,0 & 33,3 & 20,0 & 0,0 & 36,4 & 37,5 \\
\hline \multirow{3}{*}{ Estrutura } & independente & 11,1 & 25,0 & 0,0 & 0,0 & 12,5 & 25,0 & 25,0 & 0,0 & 0,0 & 0,0 & 7,1 & 22,2 & 16,7 & 6,7 & 25,0 & 0,0 & 12,5 \\
\hline & integrada & 66,7 & 62,5 & 66,7 & 87,5 & 50,0 & 37,5 & 75,0 & 60,0 & 90,0 & 75,0 & 78,6 & 44,4 & 75,0 & 60,0 & 37,5 & 90,9 & 62,5 \\
\hline & comercial & 22,2 & 12,5 & 33,3 & 12,5 & 37,5 & 37,5 & 0,0 & 40,0 & 10,0 & 25,0 & 14,3 & 33,3 & 8,3 & 33,3 & 37,5 & 9,1 & 25,0 \\
\hline \multirow{4}{*}{ Meta } & tend. & 11,1 & 12,5 & 33,3 & 12,5 & 0,0 & 0,0 & 0,0 & 20,0 & 20,0 & 25,0 & 14,3 & 0,0 & 8,3 & 13,3 & 0,0 & 9,1 & 25,0 \\
\hline & $\min$. & 33,3 & 12,5 & 33,3 & 87,5 & 0,0 & 0,0 & 50,0 & 20,0 & 60,0 & 50,0 & 50,0 & 0,0 & 58,3 & 13,3 & 0,0 & 36,4 & 62,5 \\
\hline & merc. & 14,8 & 12,5 & 33,3 & 0,0 & 12,5 & 25,0 & 0,0 & 20,0 & 10,0 & 25,0 & 7,1 & 22,2 & 8,3 & 20,0 & 25,0 & 18,2 & 0,0 \\
\hline & nda. & 40,7 & 62,5 & 0,0 & 12,5 & 75,0 & 75,0 & 50,0 & 40,0 & 20,0 & 0,0 & 28,6 & 77,8 & 25,0 & 53,3 & 75,0 & 36,4 & 12,5 \\
\hline \multicolumn{19}{|c|}{ b - Frequências calculadas na LINHA } \\
\hline \multirow{3}{*}{\multicolumn{2}{|c|}{ Características }} & Variáveis & \multicolumn{4}{|c|}{ Amplitude } & \multicolumn{4}{|c|}{ Duração } & \multicolumn{3}{|c|}{ Última } & \multicolumn{2}{|c|}{ Perfil } & \multicolumn{3}{|c|}{ Intensidade } \\
\hline & & Decisão & estado & c.O. & todas & não & não & $6-12$ & $6-12$ & + de 12 & SIM & NÃO & não fez & SIM & NÃO & peq. & média & grande \\
\hline & & Total Marginal & 29,6 & 11,1 & 29,6 & 29,6 & 29,6 & 14,8 & 18,5 & 37,0 & 14,8 & 51,9 & 33,3 & 44,4 & 55,6 & 29,6 & 40,7 & 29,6 \\
\hline \multirow{3}{*}{ Tamanho } & pequena & 29,6 & 50,0 & 0,0 & 0,0 & 50,0 & 37,5 & 25,0 & 25,0 & 12,5 & 0,0 & 50,0 & 50,0 & 50,0 & 50,0 & 37,5 & 37,5 & 25,0 \\
\hline & média & 29,6 & 25,0 & 12,5 & 25,0 & 37,5 & 50,0 & 12,5 & 12,5 & 25,0 & 37,5 & 12,5 & 50,0 & 25,0 & 75,0 & 50,0 & 37,5 & 12,5 \\
\hline & grande & 40,7 & 18,2 & 18,2 & 54,5 & 9,1 & 9,1 & 9,1 & 18,2 & 63,6 & 9,1 & 81,8 & 9,1 & 54,5 & 45,5 & 9,1 & 45,5 & 45,5 \\
\hline \multirow{3}{*}{ Status } & novo & 40,7 & 9,1 & 18,2 & 27,3 & 45,5 & 36,4 & 18,2 & 18,2 & 27,3 & 27,3 & 27,3 & 45,5 & 36,4 & 63,6 & 36,4 & 36,4 & 27,3 \\
\hline & exp. reg & 33,3 & 66,7 & 0,0 & 0,0 & 33,3 & 44,4 & 11,1 & 22,2 & 22,2 & 0,0 & 55,6 & 44,4 & 44,4 & 55,6 & 44,4 & 33,3 & 22,2 \\
\hline & exp. CO & 25,9 & 14,3 & 14,3 & 71,4 & 0,0 & 0,0 & 14,3 & 14,3 & 71,4 & 14,3 & 85,7 & 0,0 & 57,1 & 42,9 & 0,0 & 57,1 & 42,9 \\
\hline \multirow{3}{*}{ Estrutura } & independente & 11,1 & 66,7 & 0,0 & 0,0 & 33,3 & 66,7 & 33,3 & 0,0 & 0,0 & 0,0 & 33,3 & 66,7 & 66,7 & 33,3 & 66,7 & 0,0 & 33,3 \\
\hline & integrada & 66,7 & 27,8 & 11,1 & 38,9 & 22,2 & 16,7 & 16,7 & 16,7 & 50,0 & 16,7 & 61,1 & 22,2 & 50,0 & 50,0 & 16,7 & 55,6 & 27,8 \\
\hline & comercial & 22,2 & 16,7 & 16,7 & 16,7 & 50,0 & 50,0 & 0,0 & 33,3 & 16,7 & 16,7 & 33,3 & 50,0 & 16,7 & 83,3 & 50,0 & 16,7 & 33,3 \\
\hline \multirow{4}{*}{ Meta } & tendência & 11,1 & 33,3 & 33,3 & 33,3 & 0,0 & 0,0 & 0,0 & 33,3 & 66,7 & 33,3 & 66,7 & 0,0 & 33,3 & 66,7 & 0,0 & 33,3 & 66,7 \\
\hline & minimizar & 33,3 & 11,1 & 11,1 & 77,8 & 0,0 & 0,0 & 22,2 & 11,1 & 66,7 & 22,2 & 77,8 & 0,0 & 77,8 & 22,2 & 0,0 & 44,4 & 55,6 \\
\hline & mercado & 14,8 & 25,0 & 25,0 & 0,0 & 25,0 & 50,0 & 0,0 & 25,0 & 25,0 & 25,0 & 25,0 & 50,0 & 25,0 & 75,0 & 50,0 & 50,0 & 0,0 \\
\hline & nda. & 40,7 & 45,5 & 0,0 & 9,1 & 54,5 & 54,5 & 18,2 & 18,2 & 18,2 & 0,0 & 36,4 & 63,6 & 27,3 & 72,7 & 54,5 & 36,4 & 9,1 \\
\hline
\end{tabular}


Tabela 15. Resultados dos cruzamentos das variáveis característica com a variável informações utilizadas (em valores percentuais). (a) frequências calculadas na direção das colunas; (b) frequências calculadas na direção das linhas

\begin{tabular}{|c|c|c|c|c|c|c|c|c|c|c|c|c|c|c|c|c|}
\hline \multicolumn{17}{|c|}{ a - Percentuais calculados na COLUNA } \\
\hline \multirow{2}{*}{\multicolumn{2}{|c|}{ Características }} & \multirow{2}{*}{$\begin{array}{c}\text { Informações } \\
\text { utilizadas }\end{array}$} & \multicolumn{2}{|c|}{ disp milho } & \multicolumn{2}{|c|}{ cidade } & \multicolumn{2}{|c|}{ granjas } & \multicolumn{2}{|c|}{ associações } & \multicolumn{2}{|c|}{ visita empresas } & \multicolumn{2}{|c|}{ empresas setor } & \multicolumn{2}{|c|}{ consultor externc } \\
\hline & & & $\mathrm{SIM}$ & NÃO & SIM & NÃO & SIM & NÃO & SIM & NÃO & SIM & NÃO & SIM & NÃO & SIM & NÃO \\
\hline & & Total Marginal & 81,5 & 18,5 & 66,7 & 33,3 & 48,1 & 51,9 & 44,4 & 55,6 & 40,7 & 59,3 & 40,7 & 59,3 & 18,5 & 81,5 \\
\hline \multirow{3}{*}{ Tamanho } & pequena & 29,6 & 31,8 & 20,0 & 27,8 & 33,3 & 23,1 & 35,7 & 25,0 & 33,3 & 27,3 & 31,3 & 27,3 & 31,3 & 20,0 & 31,8 \\
\hline & média & 29,6 & 22,7 & 60,0 & 22,2 & 44,4 & 23,1 & 35,7 & 16,7 & 40,0 & 27,3 & 31,3 & 27,3 & 31,3 & 20,0 & 31,8 \\
\hline & grande & 40,7 & 45,5 & 20,0 & 50,0 & 22,2 & 53,8 & 28,6 & 58,3 & 26,7 & 45,5 & 37,5 & 45,5 & 37,5 & 60,0 & 36,4 \\
\hline \multirow{3}{*}{ Status } & novo & 40,7 & 36,4 & 60,0 & 38,9 & 44,4 & 38,5 & 42,9 & 33,3 & 46,7 & 54,5 & 31,3 & 36,4 & 43,8 & 60,0 & 36,4 \\
\hline & exp. reg & 33,3 & 36,4 & 20,0 & 27,8 & 44,4 & 30,8 & 35,7 & 25,0 & 40,0 & 18,2 & 43,8 & 36,4 & 31,3 & 20,0 & 36,4 \\
\hline & exp. CO & 25,9 & 27,3 & 20,0 & 33,3 & 11,1 & 30,8 & 21,4 & 41,7 & 13,3 & 27,3 & 25,0 & 27,3 & 25,0 & 20,0 & 27,3 \\
\hline \multirow{3}{*}{ Estrutura } & independente & 11,1 & 9,1 & 20,0 & 5,6 & 22,2 & 7,7 & 14,3 & 8,3 & 13,3 & 9,1 & 12,5 & 18,2 & 6,3 & 0,0 & 13,6 \\
\hline & integrada & 66,7 & 77,3 & 20,0 & 66,7 & 66,7 & 61,5 & 71,4 & 75,0 & 60,0 & 54,5 & 75,0 & 54,5 & 75,0 & 60,0 & 68,2 \\
\hline & comercial & 22,2 & 13,6 & 60,0 & 27,8 & 11,1 & 30,8 & 14,3 & 16,7 & 26,7 & 36,4 & 12,5 & 27,3 & 18,8 & 40,0 & 18,2 \\
\hline \multirow{4}{*}{ Meta } & tend. & 11,1 & 9,1 & 20,0 & 11,1 & 11,1 & 23,1 & 0,0 & 16,7 & 6,7 & 18,2 & 6,3 & 9,1 & 12,5 & 20,0 & 9,1 \\
\hline & $\min$. & 33,3 & 40,9 & 0,0 & 44,4 & 11,1 & 38,5 & 28,6 & 58,3 & 13,3 & 45,5 & 25,0 & 54,5 & 18,8 & 40,0 & 31,8 \\
\hline & merc. & 14,8 & 9,1 & 40,0 & 22,2 & 0,0 & 7,7 & 21,4 & 8,3 & 13,3 & 9,1 & 18,8 & 9,1 & 18,8 & 0,0 & 18,2 \\
\hline & nda. & 40,7 & 40,9 & 40,0 & 22,2 & 77,8 & 30,8 & 50,0 & 16,7 & 66,7 & 27,3 & 50,0 & 27,3 & 50,0 & 40,0 & 40,9 \\
\hline \multicolumn{17}{|c|}{ b - Percentuais calculados na LINHA } \\
\hline \multirow{3}{*}{\multicolumn{2}{|c|}{ Características }} & Informações & \multicolumn{2}{|c|}{ disp milho } & \multicolumn{2}{|c|}{ cidade } & \multicolumn{2}{|c|}{ granjas } & \multicolumn{2}{|c|}{ associações } & \multicolumn{2}{|c|}{ visita empresas } & \multicolumn{2}{|c|}{ empresas setor } & \multicolumn{2}{|c|}{ consultor externo } \\
\hline & & utilizadas & SIM & NÃO & SIM & NÃO & SIM & NÃO & SIM & NÃO & SIM & NÃO & SIM & NÃO & SIM & NÃO \\
\hline & & Total Marginal & 81,5 & 18,5 & 66,7 & 33,3 & 48,1 & 51,9 & 44,4 & 55,6 & 40,7 & 59,3 & 40,7 & 59,3 & 18,5 & 81,5 \\
\hline \multirow{3}{*}{ Tamanho } & pequena & 29,6 & 87,5 & 12,5 & 62,5 & 37,5 & 37,5 & 62,5 & 37,5 & 62,5 & 37,5 & 62,5 & 37,5 & 62,5 & 12,5 & 87,5 \\
\hline & média & 29,6 & 62,5 & 37,5 & 50,0 & 50,0 & 37,5 & 62,5 & 25,0 & 75,0 & 37,5 & 62,5 & 37,5 & 62,5 & 12,5 & 87,5 \\
\hline & grande & 40,7 & 90,9 & 9,1 & 81,8 & 18,2 & 63,6 & 36,4 & 63,6 & 36,4 & 45,5 & 54,5 & 45,5 & 54,5 & 27,3 & 72,7 \\
\hline & novo & 40,7 & 72,7 & 27,3 & 63,6 & 36,4 & 45,5 & 54,5 & 36,4 & 63,6 & 54,5 & 45,5 & 36,4 & 63,6 & 27,3 & 72,7 \\
\hline Status & exp. reg & 33,3 & 88,9 & 11,1 & 55,6 & 44,4 & 44,4 & 55,6 & 33,3 & 66,7 & 22,2 & 77,8 & 44,4 & 55,6 & 11,1 & 88,9 \\
\hline & exp. CO & 25,9 & 85,7 & 14,3 & 85,7 & 14,3 & 57,1 & 42,9 & 71,4 & 28,6 & 42,9 & 57,1 & 42,9 & 57,1 & 14,3 & 85,7 \\
\hline & independente & 11,1 & 66,7 & 33,3 & 33,3 & 66,7 & 33,3 & 66,7 & 33,3 & 66,7 & 33,3 & 66,7 & 66,7 & 33,3 & 0,0 & 100,0 \\
\hline Estrutura & integrada & 66,7 & 94,4 & 5,6 & 66,7 & 33,3 & 44,4 & 55,6 & 50,0 & 50,0 & 33,3 & 66,7 & 33,3 & 66,7 & 16,7 & 83,3 \\
\hline & comercial & 22,2 & 50,0 & 50,0 & 83,3 & 16,7 & 66,7 & 33,3 & 33,3 & 66,7 & 66,7 & 33,3 & 50,0 & 50,0 & 33,3 & 66,7 \\
\hline & tend. & 11,1 & 66,7 & 33,3 & 66,7 & 33,3 & 100,0 & 0,0 & 66,7 & 33,3 & 66,7 & 33,3 & 33,3 & 66,7 & 33,3 & 66,7 \\
\hline Mata & $\min$. & 33,3 & 100,0 & 0,0 & 88,9 & 11,1 & 55,6 & 44,4 & 77,8 & 22,2 & 55,6 & 44,4 & 66,7 & 33,3 & 22,2 & 77,8 \\
\hline Mieta & merc. & 14,8 & 50,0 & 50,0 & 100,0 & 0,0 & 25,0 & 75,0 & 25,0 & 50,0 & 25,0 & 75,0 & 25,0 & 75,0 & 0,0 & 100,0 \\
\hline & nda. & 40,7 & 81,8 & 18,2 & 36,4 & 63,6 & 36,4 & 63,6 & 18,2 & 90,9 & 27,3 & 72,7 & 27,3 & 72,7 & 18,2 & 81,8 \\
\hline
\end{tabular}

Fonte: Dados da pesquisa 
Tabela 16. Resultados dos cruzamentos das variáveis característica com a variável comparações monetárias (em valores percentuais). (a) frequências calculadas na direção das colunas; (b) frequências calculadas na direção das linhas

\begin{tabular}{|c|c|c|c|c|c|c|c|c|c|c|}
\hline \multirow{2}{*}{\multicolumn{2}{|c|}{ Características }} & \multirow{3}{*}{$\begin{array}{c}\text { Comparações } \\
\text { monetárias }\end{array}$} & \multicolumn{2}{|c|}{ disp milho } & \multicolumn{2}{|c|}{ cidade } & \multicolumn{2}{|c|}{ granjas } & \multicolumn{2}{|c|}{ associações } \\
\hline & & & SIM & NÃO & SIM & NÃO & SIM & NÃO & SIM & NÃO \\
\hline \multirow{4}{*}{ Tamanho } & & & 0,2 & 14,0 & 10,4 & & 59,3 & $40, I$ & 31,0 & 63,0 \\
\hline & pequena & 29,6 & 26,1 & 50,0 & 31,6 & 25,0 & 25,0 & 36,4 & 40,0 & 23,5 \\
\hline & média & 29,6 & 26,1 & 50,0 & 21,1 & 50,0 & 25,0 & 36,4 & 20,0 & 35,3 \\
\hline & grande & 40,7 & 47,8 & 0,0 & 47,4 & 25,0 & 50,0 & 27,3 & 40,0 & 41,2 \\
\hline \multirow{3}{*}{ Status } & novo & 40,7 & 39,1 & 50,0 & 42,1 & 37,5 & 37,5 & 45,5 & 20,0 & 52,9 \\
\hline & exp. reg & 33,3 & 30,4 & 50,0 & 26,3 & 50,0 & 25,0 & 45,5 & 50,0 & 23,5 \\
\hline & exp. CO & 25,9 & 30,4 & 0,0 & 31,6 & 12,5 & 37,5 & 9,1 & 30,0 & 23,5 \\
\hline \multirow{3}{*}{ Estrutura } & independente & 11,1 & 8,7 & 25,0 & 10,5 & 12,5 & 6,3 & 18,2 & 10,0 & 11,8 \\
\hline & integrada & 66,7 & 73,9 & 25,0 & 73,7 & 50,0 & 81,3 & 45,5 & 70,0 & 64,7 \\
\hline & comercial & 22,2 & 17,4 & 50,0 & 15,8 & 37,5 & 12,5 & 36,4 & 20,0 & 23,5 \\
\hline \multirow{4}{*}{ Meta } & tend. & 11,1 & 13,0 & 0,0 & 10,5 & 12,5 & 12,5 & 9,1 & 20,0 & 5,9 \\
\hline & $\min$. & 33,3 & 39,1 & 0,0 & 47,4 & 0,0 & 50,0 & 9,1 & 30,0 & 35,3 \\
\hline & merc. & 14,8 & 13,0 & 25,0 & 10,5 & 25,0 & 12,5 & 18,2 & 10,0 & 17,6 \\
\hline & nda. & 40,7 & 34,8 & 75,0 & 31,6 & 62,5 & 25,0 & 63,6 & 40,0 & 41,2 \\
\hline \multicolumn{11}{|c|}{ b - Percentuais calculados na LINHA } \\
\hline \multirow{3}{*}{\multicolumn{2}{|c|}{ Características }} & Comparações & \multicolumn{2}{|c|}{ disp milho } & \multicolumn{2}{|c|}{ cidade } & \multicolumn{2}{|c|}{ granjas } & \multicolumn{2}{|c|}{ associações } \\
\hline & & monetárias & SIM & NÃO & SIM & NÃO & SIM & NÃO & SIM & NÃO \\
\hline & & Total Marginal & 85,2 & 14,8 & 70,4 & 29,6 & 59,3 & 40,7 & 37,0 & 63,0 \\
\hline \multirow{3}{*}{ Tamanho } & pequena & 29,6 & 75,0 & 25,0 & 75,0 & 25,0 & 50,0 & 50,0 & 50,0 & 50,0 \\
\hline & média & 29,6 & 75,0 & 25,0 & 50,0 & 50,0 & 50,0 & 50,0 & 25,0 & 75,0 \\
\hline & grande & 40,7 & 100,0 & 0,0 & 81,8 & 18,2 & 72,7 & 27,3 & 36,4 & 63,6 \\
\hline \multirow{3}{*}{ Status } & novo & 40,7 & 81,8 & 18,2 & 72,7 & 27,3 & 54,5 & 45,5 & 18,2 & 81,8 \\
\hline & exp. reg & 33,3 & 77,8 & 22,2 & 55,6 & 44,4 & 44,4 & 55,6 & 55,6 & 44,4 \\
\hline & exp. CO & 25,9 & 100,0 & 0,0 & 85,7 & 14,3 & 85,7 & 14,3 & 42,9 & 57,1 \\
\hline \multirow{3}{*}{ Estrutura } & independen & 11,1 & 66,7 & 33,3 & 66,7 & 33,3 & 33,3 & 66,7 & 33,3 & 66,7 \\
\hline & integrada & 66,7 & 94,4 & 5,6 & 77,8 & 22,2 & 72,2 & 27,8 & 38,9 & 61,1 \\
\hline & comercial & 22,2 & 66,7 & 33,3 & 50,0 & 50,0 & 33,3 & 66,7 & 33,3 & 66,7 \\
\hline \multirow{4}{*}{ Meta } & tend. & 11,1 & 100,0 & 0,0 & 66,7 & 33,3 & 66,7 & 33,3 & 66,7 & 33,3 \\
\hline & $\min$. & 33,3 & 100,0 & 0,0 & 100,0 & 0,0 & 88,9 & 11,1 & 33,3 & 66,7 \\
\hline & merc. & 14,8 & 75,0 & 25,0 & 50,0 & 50,0 & 50,0 & 50,0 & 25,0 & 75,0 \\
\hline & nda. & 40,7 & 72,7 & 27,3 & 54,5 & 45,5 & 36,4 & 63,6 & 36,4 & 63,6 \\
\hline
\end{tabular}

Fonte: Dados da pesquisa 
Tabela 17a. Resultados dos cruzamentos das variáveis característica com as respostas "grande" ou "fator decisivo" para cada variável locacional (frequências calculadas no sentido das linhas)

\begin{tabular}{|c|c|c|c|c|c|c|c|c|c|c|c|c|c|c|c|c|c|}
\hline \multirow{2}{*}{ FATORES RELACIONADOS } & \multirow{2}{*}{\multicolumn{3}{|c|}{$\begin{array}{c}\text { Tamanho } \\
\text { pequena média grande }\end{array}$}} & \multirow{2}{*}{\multicolumn{3}{|c|}{$\begin{array}{r}\text { Status } \\
0 \text { exp. reg } \\
\end{array}$}} & \multicolumn{3}{|c|}{ Origem } & \multicolumn{3}{|c|}{ Estrutura } & \multicolumn{4}{|c|}{ Meta } & \multirow{2}{*}{$\begin{array}{c}\% \text { de resp } \\
3 \text { e } 4 \\
\end{array}$} \\
\hline & & & & & & & local & C.O. & migr. & indep & integrada & comerc. & tend. & $\min$. & merc. & nda. & \\
\hline \multicolumn{18}{|l|}{ Mão-de-obra } \\
\hline Custos salariais & 42,9 & 28,6 & 28,6 & 42,9 & 28,6 & 28,6 & 42,9 & 0,0 & 57,1 & 0,0 & 71,4 & 28,6 & 14,3 & 28,6 & 28,6 & 28,6 & 25,9 \\
\hline Qualidade mão-de-obra & 0,0 & 40,0 & 60,0 & 40,0 & 0,0 & 60,0 & 20,0 & 0,0 & 80,0 & 0,0 & 60,0 & 40,0 & 0,0 & 60,0 & 40,0 & 0,0 & 18,5 \\
\hline Disponibilidade mão-de-obra & 40,0 & 10,0 & 50,0 & 30,0 & 20,0 & 50,0 & 40,0 & 10,0 & 50,0 & 10,0 & 70,0 & 20,0 & 20,0 & 50,0 & 10,0 & 20,0 & 37,0 \\
\hline \multicolumn{18}{|l|}{ Matérias-primas } \\
\hline Proximidade às lavouras milho & 33,3 & 25,0 & 41,7 & 37,5 & 37,5 & 25,0 & 50,0 & 4,2 & 45,8 & 12,5 & 70,8 & 16,7 & 8,3 & 37,5 & 12,5 & 41,7 & 88,9 \\
\hline Nível custo milho & 36,4 & 27,3 & 36,4 & 36,4 & 40,9 & 22,7 & 50,0 & 0,0 & 50,0 & 13,6 & 72,7 & 13,6 & 9,1 & 31,8 & 13,6 & 45,5 & 81,5 \\
\hline Proximidade fontes farelo soja & 40,0 & 20,0 & 40,0 & 40,0 & 30,0 & 30,0 & 55,0 & 0,0 & 45,0 & 10,0 & 80,0 & 10,0 & 10,0 & 40,0 & 10,0 & 40,0 & 74,1 \\
\hline Nível custo farelo soja & 50,0 & 12,5 & 37,5 & 37,5 & 31,3 & 31,3 & 50,0 & 6,3 & 43,8 & 12,5 & 75,0 & 12,5 & 12,5 & 31,3 & 12,5 & 43,8 & 59,3 \\
\hline \multicolumn{18}{|l|}{ Ambiente } \\
\hline Problemas de expansão & 25,0 & 50,0 & 25,0 & 50,0 & 50,0 & 0,0 & 50,0 & 0,0 & 50,0 & 0,0 & 50,0 & 50,0 & 25,0 & 25,0 & 25,0 & 25,0 & 14,8 \\
\hline Problemas ambientais & 33,3 & 16,7 & 50,0 & 33,3 & 16,7 & 50,0 & 33,3 & 0,0 & 66,7 & 16,7 & 50,0 & 33,3 & 16,7 & 50,0 & 16,7 & 16,7 & 22,2 \\
\hline \multicolumn{18}{|l|}{ Infra-estrutura } \\
\hline Disponibilidade de serviços & 42,9 & 28,6 & 28,6 & 42,9 & 28,6 & 28,6 & 57,1 & 0,0 & 42,9 & 14,3 & 57,1 & 28,6 & 0,0 & 28,6 & 14,3 & 57,1 & 25,9 \\
\hline Qualidade da infra-estrutura & 40,0 & 30,0 & 30,0 & 40,0 & 30,0 & 30,0 & 50,0 & 10,0 & 40,0 & 20,0 & 50,0 & 30,0 & 20,0 & 30,0 & 10,0 & 40,0 & 37,0 \\
\hline \multicolumn{18}{|l|}{ Poder público } \\
\hline Incentivos estaduais & 20,0 & 20,0 & 60,0 & 40,0 & 20,0 & 40,0 & 40,0 & 0,0 & 60,0 & 0,0 & 100,0 & 0,0 & 0,0 & 60,0 & 0,0 & 40,0 & 37,0 \\
\hline Incentivos municipais & 0,0 & 40,0 & 60,0 & 40,0 & 0,0 & 60,0 & 40,0 & 0,0 & 60,0 & 0,0 & 100,0 & 0,0 & 0,0 & 80,0 & 20,0 & 0,0 & 18,5 \\
\hline \multicolumn{18}{|l|}{ Políticas desenvolvimento regional } \\
\hline \multirow{2}{*}{\multicolumn{5}{|c|}{ Outros }} & 35,3 & 17,6 & 52,9 & 5,9 & 41,2 & 11,8 & 70,6 & 17,6 & 5,9 & 29,4 & 17,6 & 47,1 & 63,0 \\
\hline Proximidade mercados & 38,9 & 27,8 & 33,3 & 38,9 & 38,9 & 22,2 & 55,6 & & 38.9 & 16.7 & & & & 33,3 & 5.6 & 500 & 667 \\
\hline Preferência individual & 38,5 & 38,5 & 23,1 & 53,8 & 38,5 & 7,7 & 53,8 & 7,7 & 38,5 & 15,4 & 46,2 & 38,5 & 15,4 & 23,1 & 23,1 & 38,5 & 48,1 \\
\hline Vínculo familiar & 40,0 & 40,0 & 20,0 & 40,0 & 60,0 & 0,0 & 60,0 & 20,0 & 20,0 & 40,0 & 40,0 & 20,0 & 0,0 & 20,0 & 0,0 & 80,0 & 18,5 \\
\hline Participação relativa por categoria & 29,6 & 29,6 & 40,7 & 40,7 & 33,3 & 25,9 & 44,4 & 3,7 & 51,9 & 11,1 & 66,7 & 22,2 & 11,1 & 33,3 & 14,8 & 40,7 & \\
\hline
\end{tabular}


Tabela 17b. Resultados dos cruzamentos das variáveis característica com as respostas "grande" ou "fator decisivo" para cada variável locacional (frequências calculadas no sentido das colunas)

\begin{tabular}{|c|c|c|c|c|c|c|c|c|c|c|c|c|c|c|c|c|c|}
\hline \multirow{2}{*}{ FATORES RELACIONADOS } & \multirow{2}{*}{\multicolumn{3}{|c|}{$\begin{array}{c}\text { Tamanho } \\
\text { pequena média grande }\end{array}$}} & \multirow{2}{*}{\multicolumn{3}{|c|}{$\begin{array}{c}\text { Status } \\
\text { novo exp. reg exp. Co }\end{array}$}} & \multirow{2}{*}{\multicolumn{3}{|c|}{ Origem }} & \multirow{2}{*}{\multicolumn{3}{|c|}{$\begin{array}{c}\text { Estrutura } \\
\text { inden }\end{array}$}} & \multicolumn{4}{|c|}{ Meta } & \multirow{2}{*}{$\begin{array}{c}\% \text { de resp. } \\
3 \text { e } 4\end{array}$} \\
\hline & & & & & & & & & & & & & tend. & $\min$. & merc. & nda. & \\
\hline \multicolumn{18}{|l|}{ Mão-de-obra } \\
\hline Custos salariais & 37,5 & 25,0 & 18,2 & 27,3 & 22,2 & 28,6 & 25,0 & 0,0 & 28,6 & 0,0 & 27,8 & 33,3 & 33,3 & 22,2 & 50,0 & 18,2 & 25,9 \\
\hline Qualidade mão-de-obra & 0,0 & 25,0 & 27,3 & 18,2 & 0,0 & 42,9 & 8,3 & 0,0 & 28,6 & 0,0 & 16,7 & 33,3 & 0,0 & 33,3 & 50,0 & 0,0 & 18,5 \\
\hline Disponibilidade mão-de-obra & 50,0 & 12,5 & 45,5 & 27,3 & 22,2 & 71,4 & 33,3 & 100,0 & 35,7 & 33,3 & 38,9 & 33,3 & 66,7 & 55,6 & 25,0 & 18,2 & 37,0 \\
\hline \multicolumn{18}{|l|}{ Matérias-primas } \\
\hline Proximidade às lavouras milho & 100,0 & 75,0 & 90,9 & 81,8 & 100,0 & 85,7 & 100,0 & 100,0 & 78,6 & 100,0 & 94,4 & 66,7 & 66,7 & 100,0 & 75,0 & 90,9 & 88,9 \\
\hline Nível custo milho & 100,0 & 75,0 & 72,7 & 72,7 & 100,0 & 71,4 & 91,7 & 0,0 & 78,6 & 100,0 & 88,9 & 50,0 & 66,7 & 77,8 & 75,0 & 90,9 & 81,5 \\
\hline Proximidade fontes farelo soja & 100,0 & 50,0 & 72,7 & 72,7 & 66,7 & 85,7 & 91,7 & 0,0 & 64,3 & 66,7 & 88,9 & 33,3 & 66,7 & 88,9 & 50,0 & 72,7 & 74,1 \\
\hline Nível custo farelo soja & 100,0 & 25,0 & 54,5 & 54,5 & 55,6 & 71,4 & 66,7 & 100,0 & 50,0 & 66,7 & 66,7 & 33,3 & 66,7 & 55,6 & 50,0 & 63,6 & 59,3 \\
\hline \multicolumn{18}{|l|}{ Ambiente } \\
\hline Problemas de expansão & 12,5 & 25,0 & 9,1 & 18,2 & 22,2 & 0,0 & 16,7 & 0,0 & 14,3 & 0,0 & 11,1 & 33,3 & 33,3 & 11,1 & 25,0 & 9,1 & 14,8 \\
\hline Problemas ambientais & 25,0 & 12,5 & 27,3 & 18,2 & 11,1 & 42,9 & 16,7 & 0,0 & 28,6 & 33,3 & 16,7 & 33,3 & 33,3 & 33,3 & 25,0 & 9,1 & 22,2 \\
\hline Boas condições $p /$ expansões & 50,0 & 37,5 & 72,7 & 54,5 & 55,6 & 57,1 & 50,0 & 100,0 & 57,1 & 66,7 & 50,0 & 66,7 & 33,3 & 66,7 & 75,0 & 45,5 & 55,6 \\
\hline \multicolumn{18}{|l|}{ Infra-estrutura } \\
\hline Disponibilidade de serviços & 37,5 & 25,0 & 18,2 & 27,3 & 22,2 & 28,6 & 33,3 & 0,0 & 21,4 & 33,3 & 22,2 & 33,3 & 0,0 & 22,2 & 25,0 & 36,4 & 25,9 \\
\hline Qualidade da infra-estrutura & 50,0 & 37,5 & 27,3 & 36,4 & 33,3 & 42,9 & 41,7 & 100,0 & 28,6 & 66,7 & 27,8 & 50,0 & 66,7 & 33,3 & 25,0 & 36,4 & 37,0 \\
\hline \multicolumn{18}{|l|}{ Poder público } \\
\hline Incentivos estaduais & 25,0 & 25,0 & 54,5 & 36,4 & 22,2 & 57,1 & 33,3 & 0,0 & 42,9 & 0,0 & 55,6 & 0,0 & 0,0 & 66,7 & 0,0 & 36,4 & 37,0 \\
\hline Incentivos municipais & 0,0 & 25,0 & 27,3 & 18,2 & 0,0 & 42,9 & 16,7 & 0,0 & 21,4 & 0,0 & 27,8 & 0,0 & 0,0 & 44,4 & 25,0 & 0,0 & 18,5 \\
\hline \multicolumn{18}{|l|}{ Políticas desenvolvimento regional } \\
\hline Progr desen regional & 87,5 & 50,0 & 54,5 & 72,7 & 66,7 & 42,9 & 75,0 & 100,0 & 50,0 & 66,7 & 66,7 & 50,0 & 33,3 & 55,6 & 75,0 & 72,7 & 63,0 \\
\hline \multicolumn{18}{|l|}{ Outros } \\
\hline Proximidade mercados & 87,5 & 62,5 & 54,5 & 63,6 & 77,8 & 57,1 & 83,3 & 100,0 & 50,0 & 100,0 & 66,7 & 50,0 & 66,7 & 66,7 & 25,0 & 81,8 & 66,7 \\
\hline Preferência individual & 62,5 & 62,5 & 27,3 & 63,6 & 55,6 & 14,3 & 58,3 & 100,0 & 35,7 & 66,7 & 33,3 & 83,3 & 66,7 & 33,3 & 75,0 & 45,5 & 48,1 \\
\hline Vínculo familiar & 25,0 & 25,0 & 9,1 & 18,2 & 33,3 & 0,0 & 25,0 & 100,0 & 7,1 & 66,7 & 11,1 & 16,7 & 0,0 & 11,1 & 0,0 & 36,4 & 18,5 \\
\hline Participação relativa por categoria & 29,6 & 29,6 & 40,7 & 40,7 & 33,3 & 25,9 & 44,4 & 3,7 & 51,9 & 11,1 & 66,7 & 22,2 & 11,1 & 33,3 & 14,8 & 40,7 & \\
\hline
\end{tabular}




\begin{abstract}
ANEXO B
Neste anexo está contido o questionário que foi veiculado aos 46 abatedouros/frigoríficos da região Centro-Oeste
\end{abstract}




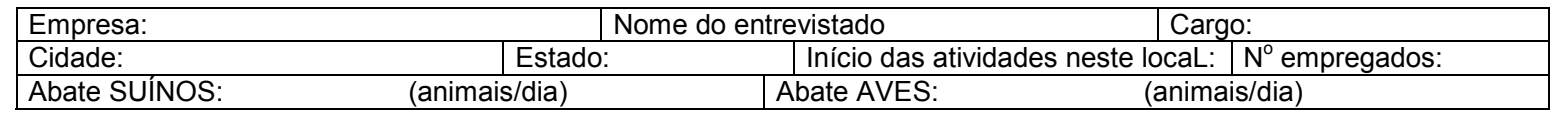

\section{CARACTERÍSTICAS DA EMPRESA}

1) Qual é o status deste estabelecimento? Configura-se em... (marque apenas 1)

\begin{tabular}{|l|}
\hline Expansão de uma empresa REGIONAL (com bases no Centro-Oeste apenas) \\
\hline Expansão de uma empresa cuja origem não é o Centro-Oeste \\
\hline Relocalização dentro do Centro-Oeste \\
\hline Relocalização de qualquer outra região do país para o Centro-Oeste (de onde p/ onde?) \\
\hline
\end{tabular}

2) Quanto à origem do negócio, informar se ... (marque apenas 1)

\begin{tabular}{|l|} 
1.Proprietário(s) oriundo(s) do local \\
\hline 2.Proprietário(s) oriundo(s) de outro local dentro da região Centro-Oeste \\
\hline 3.Constitui-se na migração de outras regiões para o Centro-Oeste (Qual?
\end{tabular}

3) A produção da empresa é (marque apenas 1):

\begin{tabular}{|l|}
\hline 1.Independente (abate apenas o que produz) \\
\hline 3.Apentenas abate (compra animais no mercado) \\
\hline
\end{tabular}

4) Esta questão deve ser apenas respondida para quem marcou 1 ou 2 na questão anterior

4A) Quanto ao abastecimento de milho, qual a porcentagem de compra? (marque em cada espaço a \% de compra para que a soma dos 5 espaços resulte em 100)

\begin{tabular}{|l|l|}
\hline 1.Da produção local \\
\hline 2.Da produção de cidades vizinhas \\
\hline 3.Da produção de outros estados da região Centro-Oeste \\
\hline 4.Da produção de outros estados que não do Centro-Oeste \\
\hline 5.Abastecimento exclusivo de rações prontas (balanceadas) \\
\hline
\end{tabular}

4B) Quanto ao abastecimento de milho, por favor marque 1 pequena 2 média

\begin{tabular}{|l|l|}
\hline & Importância nos custos do animal vivo \\
\hline & dificuldade/problemas na aquisição \\
\hline & satisfação com os níveis de preços pagos na região \\
\hline
\end{tabular}

3 grande

5) Quando da decisão de abrir esta unidade da empresa (seja ela um novo negócio, apenas mais uma filial ou uma relocalização), qual era a principal meta do empresário? (marque apenas 1)

\begin{tabular}{|l|l|}
\hline & Acompanhar a tendência da nova geografia do setor para regiões de fronteiras \\
\hline & Minimizar custos de abastecimento de matérias-primas (principalmente milho) \\
\hline & Buscar novos mercados fugindo da competição dos grandes centros de consumo/produção \\
\hline & n.d.a. - apenas iniciar uma atividade produtiva como outra qualquer \\
\hline
\end{tabular}

6) Qual é a finalidade da produção? (marque em cada espaço a \% de venda para que a soma dos 4 espaços resulte em 100)

Mercado LOCAL (ou seja, dentro do estado apenas)

Mercado REGIONAL (ou seja, dentro da região Centro-Oeste)

Mercado nacional exceto região Centro-Oeste

Mercado externo

\section{VARIÁVEIS DE DECISÃO}

7) Com relação às alternativas consideradas antes da decisão final de instalar-se onde está, a empresa (marque apenas uma)

Considerou apenas regiões dentro do estado

Considerou apenas regiões dentro do Centro-Oeste

Considerou tanto regiões dentro e fora do Centro-Oeste

Não considerou alternativas 
8) Durante quanto tempo a empresa estudou a localização do estabelecimento?

\begin{tabular}{|l|l|l|l|}
\hline & Não estudou a localização & & De 6 à 11 meses \\
\hline & De 1 à 5 meses & & Mais de 12 meses \\
\hline
\end{tabular}

9) Para a análise das condições oferecidas pelo local definitivo escolhido, essas informações abaixo foram utilizadas? Marque: $1 \mathrm{sim} 2$ não

Visita ao local/cidade

Visita à associações de agricultores/criadores da região

Visitas a outras empresas da região

Detecção da presença de empresas do setor nas redondezas

Avaliação da existência prévia de "granjas" (de aves ou suínos)

Avaliação da disponibilidade de milho e/ou farelo de soja no local

Utilização de consultor externo

10) Foram realizadas comparações monetárias dos preços dos seguintes itens. Marque 1 SIM 2 NÃO

\begin{tabular}{|l|l|l|l|}
\hline & Matérias-primas & & Preço da terra \\
\hline & Custo da mão-de-obra & & Transporte de produtos e matérias-primas \\
\hline
\end{tabular}

11) O local escolhido, foi a última alternativa a ser pesquisada?

\begin{tabular}{|l|l|l|l|l|}
\hline & SIM & & NÃO & A empresa não estudou alternativas \\
\hline
\end{tabular}

12A) A empresa havia elaborado um perfil da localização almejada antes de iniciar análise?

\begin{tabular}{|l|l|l|l|}
\hline & SIM & & NAO \\
\hline
\end{tabular}

12B) Se a resposta anterior for SIM: Este perfil foi mudado ao longo do tempo da tomada de decisão de onde estabelecer-se?

\begin{tabular}{|l|l|l|l|}
\hline & NÃO & Parcialmente & Totalmente \\
\hline
\end{tabular}

VARIÁVEIS LOCACIONAIS

13) Gostaria de saber quais dos fatores abaixo tiveram mais ou menos influência na decisão da LOCALIZAÇÃO da empresa. Para isso, conforme a importância atribuída a cada fator, por favor, marque:1 importância nula/ 2 importância pequena/ 3 importância grande/ $\mathbf{4}$ foi um dos fatores decisivos/ $\mathbf{5}$ foi o fator individualmente causador da escolha (assim, deverá ser usado em apenas um dos itens abaixo). Obs. Pediria para que lê-se todas primeiramente antes de graduá-las

\begin{tabular}{|l|l|l|l|}
\hline & Programa(s) de desenvolvimento regional & & Problemas de expansão em outras regiões \\
\hline & Nível dos custos salariais & $\begin{array}{l}\text { Problemas ambientais (relacionados aos dejetos) em regiões de } \\
\text { forte concentração da atividade }\end{array}$ \\
\hline & Qualidade da mão-de-obra & Boas condições para futuras expansões/atratividade do ambiente \\
\hline & Pisponibilidade de mão-de-obra & $\begin{array}{l}\text { Disponibilidade de serviços (assistências técnicas, centros de } \\
\text { pesquisa, recursos humanos, etc.) }\end{array}$ \\
\hline & Proximidade aos mercados consumidores & Qualidade da infra-estrutura \\
\hline & Nível de custo do milho & Preferência individual do empresário \\
\hline & Proximidade às fontes de farelo de soja & Vínculo familiar na região \\
\hline & Nível de custo do farelo de soja & Incentivos fiscais estaduais \\
\hline
\end{tabular}

14) Que nota você daria para os seguintes aspectos da infra-estrutura de onde a empresa está

$$
1 \text { precária } 2 \text { razoável } 3 \text { boa } 4 \text { ótima }
$$

\begin{tabular}{|l|l|l|l|l}
\hline Gás/eletricidade/água & & Rodovias estaduais/federais & Educação & Moradia/saúde \\
\hline & Transporte público & Estradas intermunicipais & Meio Ambiente & Comércio/lazer \\
\hline
\end{tabular}

15) O projeto de instalação da empresa esteve vinculado a algum tipo de Programa de Desenvolvimento Regional (estadual, municipal)?

\begin{tabular}{|l|l|l|l}
\hline & NÃO & SIM. Qual?:
\end{tabular}

16) A empresa está satisfeita com o local onde se instalou?

\begin{tabular}{|l|l|l|l|l|}
\hline & SIM & NÃO & & SIM, mas acredita haver um local melhor \\
\hline
\end{tabular} 


\section{REFERÊNCIAS BIBLIOGRÁFICAS}

ABLAS, L.A.Q. A organização espacial do sistema econômico: Lösch. In: LONGO, C.; RIZZIERI, J. (Org.). Economia regional e urbana: relações intersetoriais. São Paulo: IPE/USP, 1982a. p.141-162.

ADAMS, J. Review: Behavior and location - foundations for a geographic and dynamic location theory - PRED, A. Journal of Regional Science, v.10, n.2, p.259-263, 1970.

ARANTES, P.F. Espaço de sobra. Agroanalysis, v.18, n.5, p.23-24, ago. 1998.

AZZONI, C.R. Evolução das teorias de localização da atividade econômica. In:

LONGO, C.; RIZZIERI, J. (Org.). Economia regional e urbana: relações intersetoriais. São Paulo: IPE/USP, 1982a. p.69-139.

AZZONI, C.R. Teoria da localização: uma análise crítica. São Paulo: IPE/USP, 1982b. 200p. (Série Ensaios Econômicos, 19).

BRUM, B.L.R. A padronização na comercialização de carne bovina por supermercados. Piracicaba, 2000. 124p. Dissertação (M.S.) - Escola Superior de Agricultura "Luiz de Queiroz",Universidade de São Paulo.

CANO, W. Concentração e desconcentração econômica regional no Brasil: 1970/95. Economia e Sociedade, n.8, p.101-141, jun. 1997. 
CANO, W. Perspectivas para a questão regional no Brasil. Ensaios FEE, v.15, n.2, p.312-320, 1994.

CARACCIOLO, C. O modelo de Thünen e os salários na localização industrial. In: AZZONI, C.R. (Org.) Onde produzir? Aplicações da Teoria da Localização no Brasil. São Paulo: IPE/USP, 1985. p.81-106. (Série Ensaios Econômicos, 49)

CASTRO, A.C.; FONSECA, M.G.D. A dinâmica agroindustrial do Centro-Oeste. Brasília: IPEA, 1995. 220p.

COHEN, K. J.; CYERT, R. M. New considerations in the Theory of the Firm". In: KARASKA, G. J.; BRAMHALL, D. F. (Ed.) Location analysis for manufacturing. Cambridge: The MIT Press, 1969. p.329-351.

COSTA, F. G. Avaliação do potencial de expansão da soja na Amazônia Legal: uma aplicação do modelo de von Thünen. 145p. Piracicaba, 2000. 145p. Dissertação (M.S.) - Escola Superior de Agricultura "Luiz de Queiroz", Universidade de São Paulo.

CUNHA, A.S.; MUELLER, C.C.; ALVES, E.R.A. et al. Uma avaliação da sustentabilidade da agricultura nos cerrados. Estudos de Política Agrícola, n.11, p.1-204, 1994.

DINIZ C.C. A dinâmica regional recente da economia brasileira e suas perspectivas. Brasília: IPEA, jun. 1995. 45p. (Texto para discussão, 375) http:॥www.ipea.gov.br/pub/td/tda1995a.html (Ago. 1999)

EVERITT, B.S. The analysis of contingency tables. 2.ed. London: Chapman\&Hall, 1992. $164 p$.

FARINA, E.M.M.Q. Sadia: o desafio de manter a liderança no mercado de frangos. In: FARINA, E.M.M.Q. (Org.) Estudos de casos em agribusiness. São Paulo: Pioneira, 1997. cap.5, p.97-130. 
FAVERET FILHO P.; PAULA, S.R.L. de. Um estudo da integração a partir do Projeto Buriti da Perdigão. BNDES Setorial, n.7, p.123-134, mar. 1998.

FCO: Fundo Constitucional de Financiamento do Centro-Oeste. Brasília: Banco do Brasil, 2000. 42p.

FCO: Informações Gerenciais - Exercício 2000. Brasília: Banco do Brasil, 2000. 23p.

FERREIRA, C.M.C. As teorias da localização e a organização espacial da economia. In: HADDAD, P.R. (Org.) Economia regional: teorias e métodos de análise. Fortaleza: BNB/ETENE, 1989. cap.2, p.67-206.

HADDAD, P.R. A agroindústria e os desequilíbrios regionais de desenvolvimento. In: HADDAD, P.R. (Org.) A competitividade do agronegócio e o desenvolvimento regional no Brasil: estudo de clusters. Brasília: CNPq/Embrapa, 1999. cap.4, p.5357.

HARVEY, D. Review: Behavior and location - foundations for a geographic and dynamic location theory - PRED, A. Geographical Review, v.59, n.2, p.312-314, 1969.

HELFAND, S.; REZENDE, G.C. de. Mudanças na distribuição espacial da produção de grãos, aves e suínos no Brasil: o papel do Centro-Oeste. Rio de Janeiro: IPEA, dez. 1998. 38p. (Texto para discussão, 611) http:॥www.ipea.gov.br/pub/td/tda 1998a.html (Ago. 1999)

HOFFMANN, R. Estatística para economistas. 2.ed. São Paulo: Livraria Pioneira, 1991. 426p.

KELLERMAN, A. Agricultural location theory 1: basic models. Environment and Planning A, v.21, p.1381-1396, 1989a.

KELLERMAN, A. Agricultural location theory 2: relaxation of assumptions and applications. Environment and Planning A, v.21, p.1427-1446, 1989 b. 
LAZZARINI, S.G.; MACHADO FILHO, C.A.P.; NEVES, M.F. et al. A indústria de nutrição animal: tendências e estratégias empresariais. In: CONGRESSO DA SOCIEDADE BRASILEIRA DE ECONOMIA E SOCIOLOGIA RURAL, 34., Aracajú, 1996. Anais. Brasília: SOBER, v.2, 1996. p.587-599.

LEMOS M.B. Impactos da abertura comercial da agricultura sobre o desenvolvimento regional brasileiro. Revista de Economia e Sociologia Rural, v.34, n.1/2, p.229252, jan.jul. 1996.

MACEDO, J. Os cerrados brasileiros: alternativa para a produção de alimentos no limiar do século XXI. Revista de Política Agrícola, v.4, n.2, p. 11-18, abr/mai/jun. 1995.

MAFIOLETTI, R. L. Formação de preços na cadeia agro-industrial da soja na década de 90. Piracicaba, 2000. 95p. Dissertação (M.S.) - Escola Superior de Agricultura "Luiz de Queiroz", Universidade de São Paulo.

MOORE, B.; TYLER, P.; ELLIOTT, D. The influence of regional development incentives and infraestructure on the location of small and medium sized companies in Europe. Urban Studies, v.28, n.6, p.1001-1026, April 1991.

MUELLER, C.C. Políticas governamentais e expansão recente da agropecuária no centro-oeste. Planejamento e Políticas Públicas, n.3, p.45-74, jun. 1990.

NORCLIFFE, G.B. A theory of manufacturing places. In: COLLINS, L.; WALKER, D.F. (Org.) Location dynamics of manufacturing activity. London: Wiley and Son, 1975. cap.1, p.19-57.

O'KELLY, M.; BRYAN, D. Agricultural theory: von Thünen's contribution to economic geography. Progress in Human Geography, v.20, n.4, p.457-475, 1996.

PACHECO, C.A. Novos padrões de localização industrial? Tendências recentes dos indicadores da produção do investimento industrial. Brasília: IPEA, mar. 1999. 
38p. (Texto para discussão, 633) http:॥www.ipea.gov.br/pub/td/tda1999a.html (Ago. 1999)

PECK, F.W. Regional development and the production of space: the role of infraestructure in the attraction of new inward investment. Environment and Planning A, v.28, p.327-339, 1996.

PEROBELLI, F.S. Transformação no padrão locacional industrial: o caso de Santa Rita do Sapucaí. Brasília: IPEA, mar. 1996. 73p. (Texto para discussão, 414) http:॥www.ipea.gov.br/pub/td/tda1996a.html (Ago. 1999)

SABOYA. L.V.; MARQUES, P.V. O reposicionamento da indústria nacional de alimentação animal na cadeia produtiva de aves e suínos. In: CONGRESSO DA SOCIEDADE BRASILEIRA DE ECONOMIA E SOCIOLOGIA RURAL, 37., Foz do Iguaçu, 1999. Anais. Brasília: Agromídia Software, 1999.

TALAMINI. T.J.D.; SANTOS FILHO, J.I. dos; CANEVER, M.D. O complexo grãoscarne e sua dinâmica recente no Brasil. In: AGUIAR, D.R.D.; PINHO, J.B. (Ed.). CONGRESSO DA SOCIEDADE BRASILEIRA DE ECONOMIA E SOCIOLOGIA RURAL, 36., Poços de Caldas, 1998. Anais. Brasília: SOBER, 1998. v.1, p.225237.

THOMPSON, B. Review: Behavior and location - foundations for a geographic and dynamic location theory - PRED, A. Economic Geography, v.45, n.2, p.183-184, 1969.

TOWNROE. Some behavioural considerations in industrial location decision. Regional Studies, v.6, n.3 p.261-272, 1972.

VARSANO, R. A guerra fiscal do ICMS: quem ganha e quem perde. Rio de Janeiro: IPEA, jul. 1997. 13p. (Texto para discussão, 500) http:॥www.ipea.gov.br/pub/td/tda1997a.html) (Ago. 1999) 
WALKER, D.F. A behavioural approach to industrial location. In: COLLINS, L.; WALKER, D.F. (Org.) Location dynamics of manufacturing activity. London: Wiley and Son, 1975. cap.5, p.135-158.

WILKINSON, J. Agroindústria e perspectivas para a produção familiar no Brasil. Políticas Agrícolas, v.2, n.1, p.101-135, 1996.

WORLD WIDE FUND FOR NATURE - WWF; SOCIEDADE DE PESQUISAS ECOLÓGICAS DO CERRADO - PRO-CER. De grão em grão o cerrado perde espaço. Brasília, $1995 . \quad$ (Documento para discussão) http:॥www.wwf.org.br/wwfpr32.htm (Jul. 1999) 


\section{APÊNDICE}

Neste apêndice está contida uma síntese sobre a Teoria Clássica da Localização, ponto de partida para o enfoque comportamentalista adotado neste trabalho 


\section{OS MODELOS CLÁSSICOS DE LOCALIZAÇÃo}

De um modo geral, as teorias de localização, como um todo, fundamentam-se, essencialmente, na interpretação das decisões empresariais com respeito ao melhor sítio onde localizar seu empreendimento/negócio (Ferreira, 1989). "Onde localizar" e "o que produzir" foram perguntas que começaram a ser respondidas há pouco mais de um século e meio. Azzoni (1982b) elucida que, embora tenham sido encontradas algumas referências ao assunto em autores como Adam Smith, David Ricardo e Karl Marx, pode-se dizer que o primeiro cientista a se preocupar sistematicamente com a problemática do espaço econômico, foi o alemão Johann Heinrich von Thünen, com seu trabalho de 1826 intitulado de "Isoliert Staat" (o estado isolado de von Thünen).

\section{von Thünen}

Basicamente, este autor se preocupou com a localização e distribuição de atividades agrícolas em torno de uma cidade (que seria o centro de consumo), originando os tão conhecidos anéis de von Thünen, que nada mais são do que "circunferências em torno da cidade, cada uma delas delimitando a área de cultivo de um produto" (Azzoni, 1986, p.17).

O cenário de estudo de von Thünen era representado por uma grande cidade no centro da economia, circundada por uma planície de igual fertilidade em todas as direções. Os habitantes da cidade deveriam ser abastecidos com os produtos agrícolas produzidos ao longo desta planície. A uma determinada distância da cidade, as terras se tornam improdutivas, não havendo qualquer comunicação com outras regiões ( $\mathrm{O}$ 'Kelly e Bryan, 1996, citando as próprias palavras de von Thünen). Este era o "estado isolado" de von Thünen. $\mathrm{O}$ autor supõe ainda custos de transporte uniformes em todas as direções como função apenas da distância e preços na cidade uniformes para todos os produtos (Azzoni, 1982a).

Considerando todos os outros fatores constantes, ele se propõe a determinar, primordialmente, a influência dos custos de transporte na localização das produções agrícolas. Devido à importância dos custos de transporte, as culturas são arranjadas ao redor do mercado (ou da cidade) num esquema concêntrico (O'Kelly e Bryan, 1996), ou seja, como o preço na cidade é constante para cada produto, a renda líquida que permanece com o agricultor diminui com o aumento da distância à cidade (Azzoni, 1982a). Assim, como a distância do mercado exerce papel decisivo na determinação da renda ela se denomina renda de situação ou renda de localização, conforme estabelece Ferreira (1989). 
A idéia básica por detrás do modelo de von Thünen é de fato bastante simples: os lotes de terra que são próximos ao mercado têm um custo implícito de transporte menor do que os lotes de mais difícil acesso (O’Kelly e Bryan, 1996). Além disso, outro fator que diferencia as glebas entre si é "o preço, ou a 'renda de localização', que as unidades econômicas estão dispostas a pagar por elas com a finalidade de afastar os outros pretendentes" (Ferreira, 1989, p.121). Isso faz com que surja um sistema de renda da terra devido a sua propriedade ou um gradiente de renda, ilustrado na Figura AP1 dentro de um modelo formalizado de uso da terra agrícola de von Thünen.

Assim, a função de renda para um dado produto pode ser expressa por:

$$
R_{i j}=E_{i}\left(P_{i}-a_{i}\right)-E_{i j} f_{i j}
$$

onde:

$i$ é a cultura;

$j$ é a localização;

$R$ é a renda por unidade de terra;

$E$ é o rendimento (produção por unidade de área);

$p$ é preço de mercado por unidade de mercadoria;

$a$ é custo de produção por unidade de mercadoria;

$f$ é custos de transporte por unidade de produto por unidade de distância;

$k$ é distância do mercado (ou da cidade).

Assim definidas as variáveis, $j_{c}$ será o limite espacial da cultura $i$.

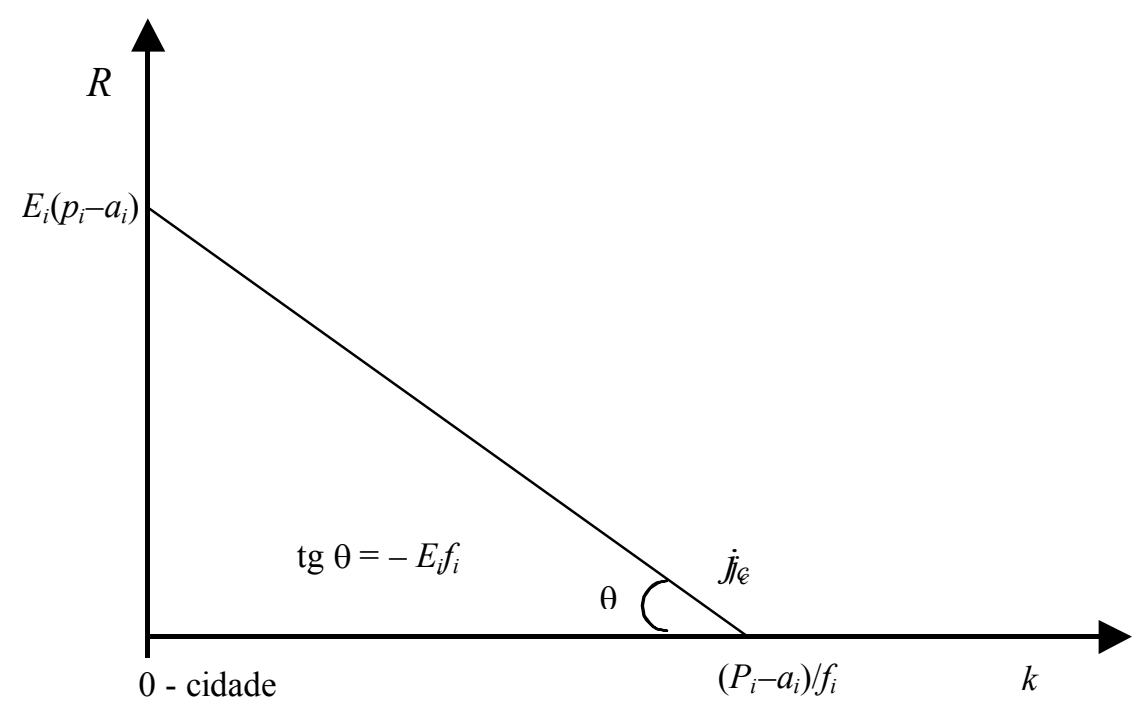

Figura 24 - Gradiente de renda da terra (adaptado de Ferreira, 1989, p.129)

Este gradiente de renda da Figura 24 ilustra o caso de apenas uma cultura (ou um só produto). Quando outros produtos com diferentes gradientes de renda são considerados, surgem as zonas de transições espaciais entre as culturas, como podem ser vistas na Figura 25. Assim, no intervalo $0 k_{0}$, o cultivo do produto A é o mais rentável de 
todos. Do ponto $k_{0}$ ao ponto $k_{1}$ a cultura mais rentável passa a ser B e assim por diante. Esta é a lógica da transição das culturas no modelo de von Thünen que estabelece a melhor distribuição das culturas em anéis que circundam a cidade. A formação destes anéis pode ser entendida girando-se o eixo das distâncias (eixo das abcissas) da Figura $25 \mathrm{em}$ torno do eixo da renda (eixo das ordenadas) centralizado no mercado, uma vez que os custos de transporte são uniformes em todas as direções. Com isso, von Thünen obteve um esquema semelhante ao da Figura 26, onde cada gradiente de renda representa uma atividade agrícola a ser localizada no estado isolado (Ferreira, 1989).

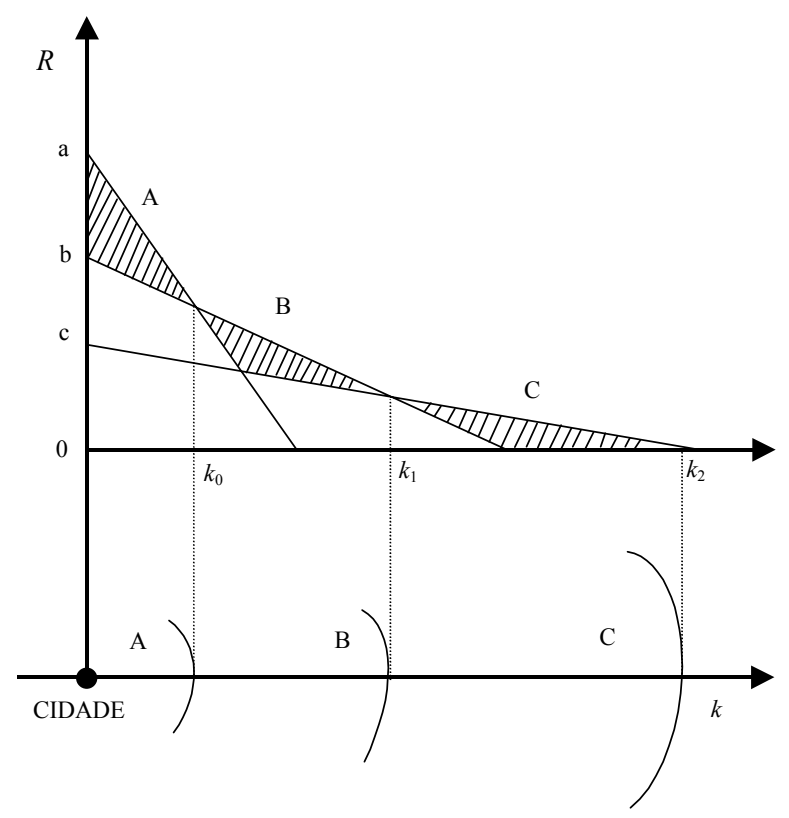

Figura 25 - Anéis de von Thünen com $n$ culturas (modificado de Ferreira, 1989, p.140)

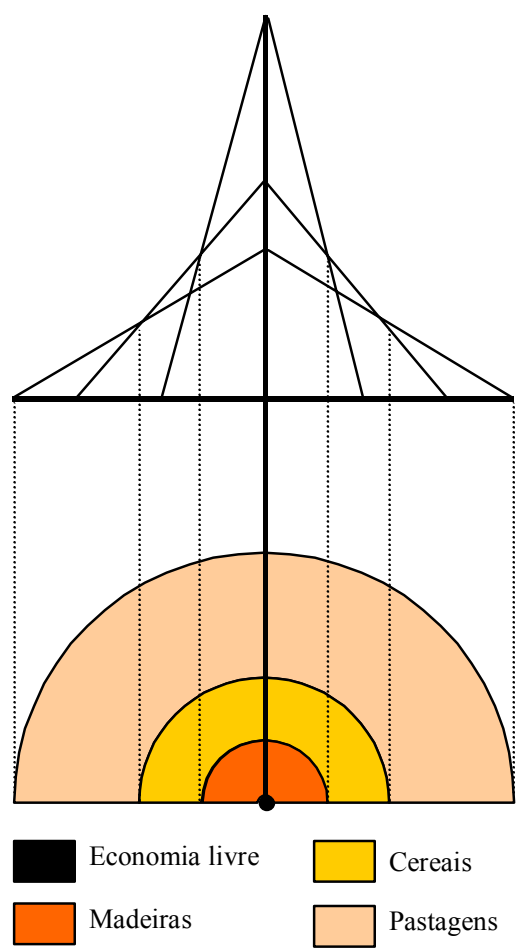

Figura 26 - Distribuição espacial das atividades agrícolas (modificado de Ferreira, 1989, p.141)

Apesar de von Thünen ser considerado por Kellerman (1989a) (e também por O'Kelly e Bryan, 1996) como o grande "fundador" da Teoria da Localização, o autor entende que a maior tese de von Thünen foi a respeito do tratamento que deu à renda da terra, a qual determinaria o arranjo das culturas ao redor da cidade e não propriamente a formalização de uma Teoria de Localização. No entanto, seu trabalho inspirou uma grande quantidade de estudos posteriores, principalmente na primeira metade do século XX, que vieram consolidar a Teoria da Localização. Até hoje seu trabalho é estudado e sempre considerado em trabalhos de geografia econômica (como 
os de Kellerman, 1989, o de O'Kelly e Bryan, 1996 e o de Costa, 2000) ou estendido a usos urbanos ou industriais (como por exemplo Caracciolo, 1985).

\section{Alfred Weber}

O alicerce da Teoria da Localização foi, por assim dizer, Alfred Weber, com seu trabalho de 1909, somente traduzido à língua inglesa, e portanto difundido, em $1929^{40}$. De acordo com Azzoni (1982b), sua obra é sem dúvida alguma, o modelo seminal da Teoria da Localização por apresentar uma exposição completa e satisfatória sobre o assunto.

Weber ateve-se à localização de atividades industriais, apresentando uma teoria geral e abstrata para a localização de uma firma individualmente (id. ibid.) ${ }^{41}$. No modelo weberiano de localização são individualizados três fatores essenciais que influenciam a decisão locacional, os quais podem ser agrupados, segundo Ferreira (1989, p.78), “em fatores gerais de âmbito regional que são o custo de transporte e o custo da mão-de-obra e um fator constituído por forças de aglomeração e de desaglomeração".

Para resolver o problema do primeiro fator, o custo do transporte influenciando a localização da firma, Weber empregou o triângulo locacional e quando incorpora as forças oriundas da mão-de-obra e dos fatores aglomerativos, utilizou as

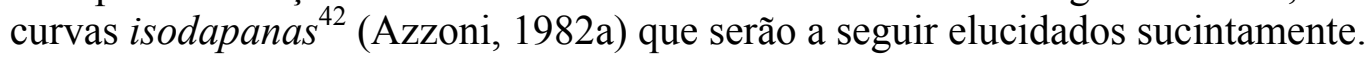

Primeiramente, deve-se entender o fator locacional no modelo de Weber como um ganho, uma redução de custos que uma determinada atividade obtém, quando escolhe sua localização em um determinado ponto. Assim, os custos totais seriam seguramente mais elevados em qualquer outra localização (Ferreira, 1989).

Weber faz algumas suposições simplificadoras, visto que pretende desenvolver uma teoria geral e abstrata sobre a complicada realidade da localização industrial. Segundo Azzoni (1982a), o autor considera três suposições gerais ${ }^{43}$ :

a) as localizações das fontes de matérias-primas são dadas e conhecidas;

${ }^{40}$ WEBER, A. Theory of location of industries. Trad. de C. J. Friedrich. Chicago: University of Chicago Press, 1929.

${ }^{41} \mathrm{Na}$ verdade, como salienta Azzoni (1982b), apesar de ser esta sua contribuição mais importante, Weber ainda ensaiou no capítulo final de sua obra desvendar os limites da teoria pura da localização com as indústrias dentro do sistema econômico como um todo, sendo assim, a primeira tentativa de formalização de uma teoria geral da localização de toda a atividade econômica.

${ }^{42}$ Como esclarece Ferreira (1989, p.99), iso, igual e dapane, despesa ou custo.

${ }^{43}$ Algumas pressuposições estão implícitas, como interpreta Azzoni (1982b, p.76): "concorrência perfeita; a idéia de que cada produtor detém um mercado ilimitado sem possibilidade de obter vantagens monopolísticas de sua escolha locacional; coeficientes técnicos de produção fixos e, como princípio orientador da atividade do agente econômico, minimização de custos". 
b) a posição e o tamanho dos centros de consumo são dados e conhecidos;

c) a mão-de-obra pode ser encontrada de forma ilimitada, a uma dada taxa de salário, em várias localizações estabelecidas e fixas.

A fim de encontrar o ponto de custos totais mínimos de transporte, Weber utiliza o triângulo locacional num caso simplificado, onde há um ponto de consumo $\mathrm{C}$ e os depósitos de matérias-primas ${ }^{44}$ melhores localizadas, $\mathrm{M}_{1}$ e $\mathrm{M}_{2}$, resolvendo o problema por meio de construções geométricas e de modelos análogos aos de equilíbrio de forças da física (Figura AP4a) (Ferreira, 1989).

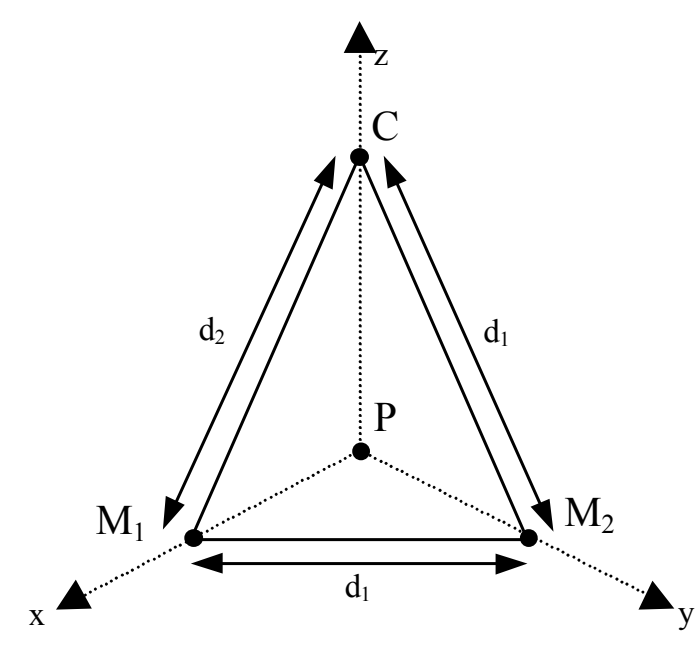

(a)

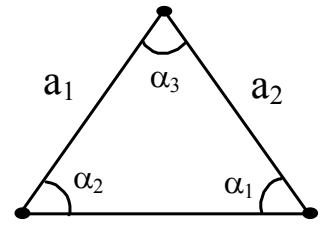

$\mathrm{a}_{3}$

Figura AP4

Figura 27- Triângulo locacional (a) e triângulo dos pesos (b) no Modelo de Weber (modificado de Ferreira, 1989, p.82)

Os custos de transporte têm papel decisivo na determinação da localização das manufaturas no modelo de Weber, sendo funções do peso físico a ser transportado e da distância a ser percorrida (Ferreira, 1989).

Na Figura 27a, $P$ é o ponto de custo total e de transporte mínimos, $d_{i}$ são as respectivas distâncias entre os pontos e $x, y$ e $z$ são os vetores que representam as forças de atração das fontes de matérias-primas 1 e 2 e do mercado C. Conforme ensina Ferreira (1989, p.81), "cada ponto $\left(\mathrm{C}, \mathrm{M}_{1}\right.$ e $\left.\mathrm{M}_{2}\right)$ cria uma 'força de atração' em sua direção que é proporcional ao peso por unidade da matéria-prima a ser transportada para o local de produção e, do local de produção para o mercado". Para resolver o problema, supõe-se que sejam necessárias $a_{l}$ toneladas de matéria-prima $m_{l}$, produzidas em $\mathrm{M}_{1} \mathrm{e}$

\footnotetext{
${ }^{44}$ Weber ainda divide as matérias-primas entre ubiquidades (encontradas em todas a partes, e portanto não exercendo qualquer força de atração) e matérias-primas localizas (no caso, $\mathrm{M}_{1}$ e $\mathrm{M}_{2}$ ) (Ferreira, 1989).
} 
$a_{2}$ toneladas de matéria-prima $m_{2}$, produzidas em $\mathrm{M}_{2}$ para se transformarem em $a_{3}$ toneladas do produto final, dando origem ao triângulo dos pesos da Figura 27b, onde $\alpha_{1}$, $\alpha_{2}$ e $\alpha_{3}$ são opostos aos lados $a_{1}, a_{2}$ e $a_{3}$, respectivamente.

A solução da determinação geométrica do ponto $P$ é ilustrada na Figura 28 através do traçado de circunferências em torno dos triângulos dos pesos, construídos sobre os lados do triângulo locacional, de modo que cada um de seus lados $d_{1}, d_{2}$ e $d_{3}$, fique oposto aos ângulos $\alpha_{1}, \alpha_{2}$ e $\alpha_{3}$, na ordem. Estas circunferências se interceptam dentro do triângulo locacional, determinando o ponto $P$ de custo mínimo de transporte (Ferreira, 1989).

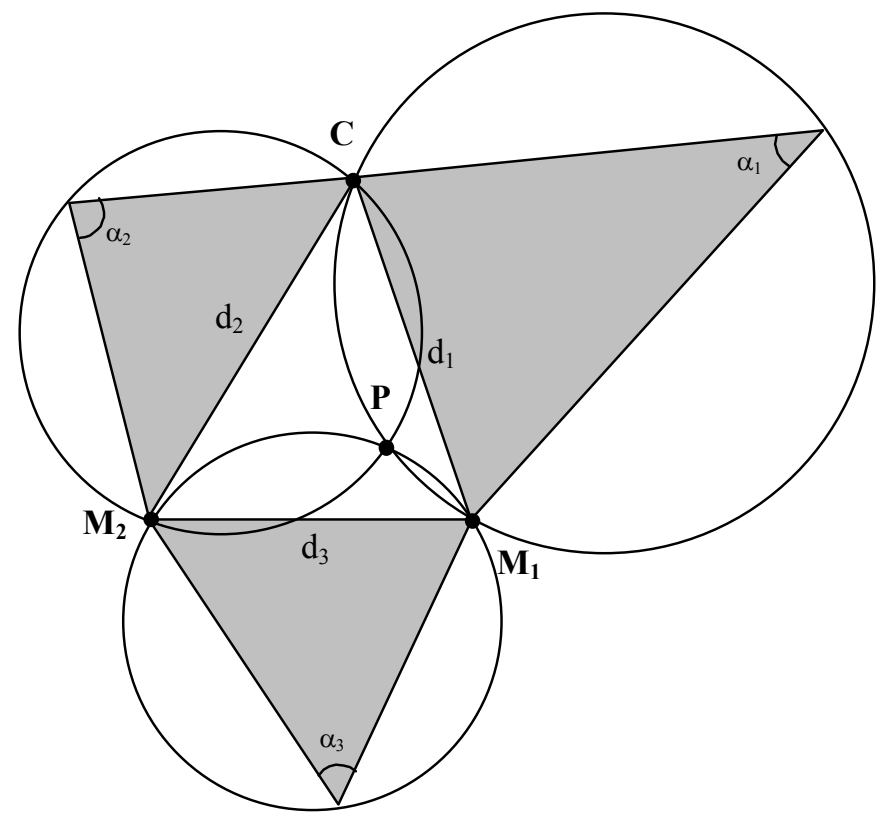

(a) - Triângulo Locacional $\mathrm{M}_{1} \mathrm{M}_{2} \mathrm{C}$

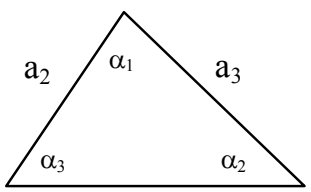

$\mathrm{a}_{1}$

Figura 28 - Triângulo locacional (a) e triângulo dos pesos (b) na determinação no ponto $P$ de custo total mínimo de transporte no modelo de Weber (modificado de Ferreira, 1989, p. 82)

Em virtude da grande importância desempenhada pelos custos de transporte na Teoria da Localização de Weber, o autor deteve-se ainda na análise da orientação das atividades industriais, dentro do modelo que apenas considera os custos de transporte. A determinação da orientação foi caracterizada por meio de uma simples relação de pesos chamada de índice material. Este índice é calculado pela proporção entre o peso de matéria-prima localizada e o peso do produto final. Um valor maior do que a unidade indica orientação para matérias-primas e um valor menor que a unidade indica orientação para o mercado (Azzoni, 1982a).

Weber, a seguir, define o conceito de peso locacional como sendo o somatório do peso do produto por unidade de produto com os pesos individuais das matérias-primas localizadas por unidade de produto. Dessa forma, o peso locacional de 
Weber encontrará valor mínimo de 1 quando os índices materiais são zero, e portanto o processo produtivo utiliza-se apenas de ubiqüidades (Ferreira, 1989). O peso locacional eleva-se gradativamente com o aumento dos índices materiais. Indústrias com alto peso locacional são atraídas para as matérias-primas, e aquelas com um baixo peso locacional para o mercado (id. ibid.).

Como pormenoriza de maneira mais completa Ferreira (1989, p.96),

"Weber denomina de matérias-primas puras aquelas que não perdem peso durante o processo de produção, de tal modo que o peso total do produto exceda, substancialmente, o peso da matéria-prima, de modo que o índice de matérias-primas $^{45}$, no caso de matérias-primas puras, será menor do que a unidade, e a indústria, então, tende a se localizar junto ao mercado. As matérias-primas brutas, que perdem peso, substancialmente, no processo de produção, tendem a orientar a localização da produção junto à fonte de matéria-prima. Quando o indice de matérias-primas for maior do que a unidade, o peso locacional será maior que 2 e, quando o peso da matériaprima bruta, que é utilizada nesse particular processo de produção, for igual ou maior do que o peso do produto final, mais o peso das outras matériasprimas localizadas, as quais, também, entram nesse processo de produção, a produção localizar-se-á junto à fonte daquela matéria-prima (...)."

Estes conceitos desenvolvidos por Weber com relação às "forças" indutoras da localização da indústria, é de grande valia para as pretensões deste trabalho, uma vez que se estuda complexos produtivos, os de aves e suínos, que são intensos em matérias-primas mais ou menos localizadas.

A determinação da localização de mínimo custo de transporte, determinada na Figura 28, fornece, então, uma primeira aproximação para se obter a localização ótima da firma. "É a partir dela que são consideradas as possíveis vantagens que outros locais podem oferecer, em termos de mão-de-obra mais barata ou mesmo no tocante a economias de aglomeração" (Azzoni, 1982b, p.20). Para o estudo destes prováveis desvios em relação ao ponto de mínimo custo de transporte, Weber utiliza-se do artifício das isodapanas, que podem ser definidas, segundo Azzoni (1982b, p.20), "como o conjunto de pontos que têm igual acréscimo de custo de transporte em relação àquele local em que esse custo é mínimo". A ilustração da Figura 29 ajuda a compreender a rationale das idéias básicas de Weber a respeito da influência da mão-deobra, onde os valores monetários sobre cada isodapana simboliza o acréscimo nos custos de transporte a partir de $P$.

${ }^{45}$ Ferreira (1989) chama de indice de matérias-primas o que Azzoni (1989b) classifica como índice material. 


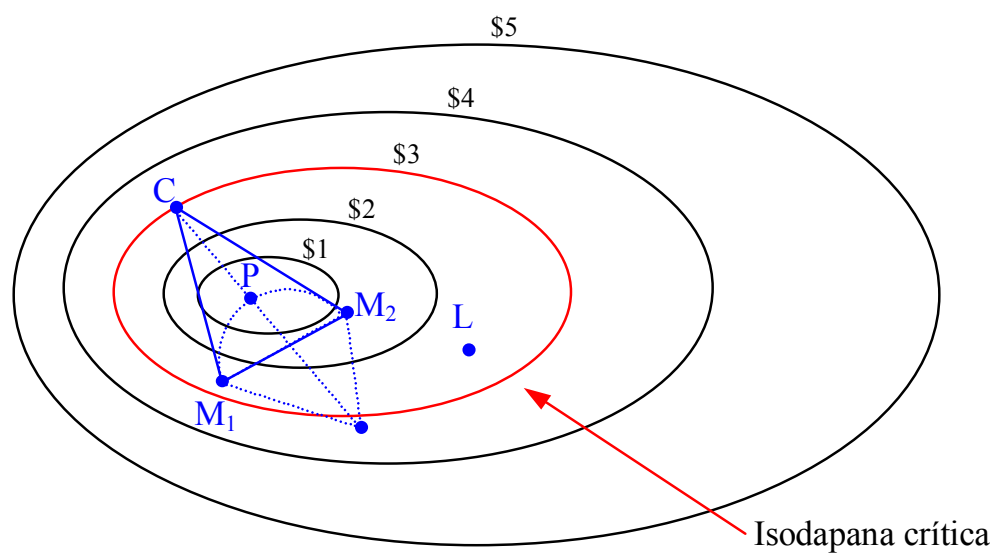

Figura 29 - Traçado das curvas isodapanas e determinação da isodapana crítica (modificado de Ferreira, 1989, p.101)

Assim, se no ponto $L$ da Figura 29, a economia nos custos devido à mãode-obra mais barata na periferia for igual a $\$ 3{ }^{46}$, valor semelhante ao acréscimo nos custos de transporte de $P$ para $L$, está determinada a isodapana crítica.

Analogamente ao que fez com a matéria-prima, Weber determina um indice de custo de trabalho e um coeficiente de trabalho ${ }^{47}$. O primeiro é definido como o custo médio do trabalho necessário para produzir uma unidade de peso de produto final. O segundo, define-se como a razão entre o índice de custo de trabalho e o peso total de materiais e produtos a ser transportado. "Quanto maiores estes índices, maior a importância do fator trabalho para a indústria e, portanto, maior a probabilidade de que seja atraída para locais com mão-de-obra barata" (Azzoni, 1982a, p.81), orientada, assim, pela mão-de-obra.

Por último, os fatores aglomerativos são considerados por Weber, ao entender que surgem economias resultantes da concentração de firmas em um local (Azzoni, 1982a), utilizando mais uma vez as isodapanas, ilustradas na Figura 30.

\footnotetext{
${ }^{46}$ Weber considera que o fator mão-de-obra fique gradativamente mais barato à medida que se afaste de $P$.

${ }^{47}$ O propósito básico destes dois conceitos é o de medir a "força de atração" exercida pelo local onde o custo da mão-de-obra é mais favorável levando em consideração "novas" possibilidades de abastecimento de matérias-primas nesse novo local orientado pela mão-de-obra.
} 


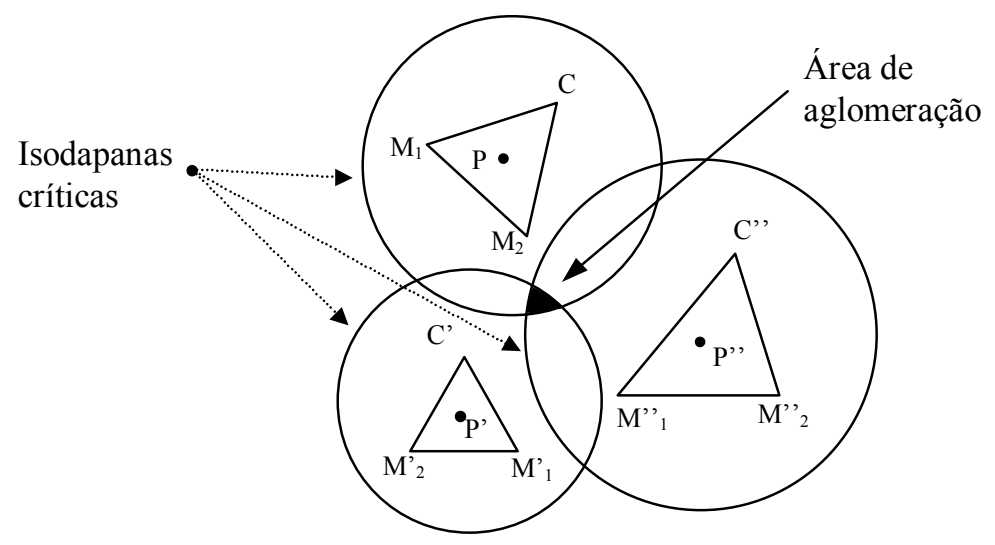

Figura 30 - Determinação da área de aglomeração no modelo de Weber (modificado de Ferreira, 1989, p. 103)

Na Figura 30, a área escurecida, resultante da interceptação das 3 (três) isodapanas críticas, seria a única possível de aglomeração (Azzoni, 1982a). Nesta região, as economias de custo devidas à aglomeração são capazes de contrabalançar os custos adicionais devidos ao afastamento das firmas dos pontos de custos mínimos (Ferreira, 1989).

Esta é, em linhas gerais, a essência da Teoria Locacional de Weber.

\section{Algumas considerações sobre a Teoria Locacional de Weber}

A principal constatação ao analisar-se as forças locacionais na teoria weberina de localização industrial é a grande importância atribuída aos custos de transporte. Seja na determinação do ponto $P$ de mínimo custo, seja na isodapana crítica, ou na determinação da região de aglomeração. A obra de Weber é, sem dúvidas, o epicentro da Teoria da Localização, cujas críticas, adaptações e aperfeiçoamentos acompanharam os trabalhos de cientistas posteriores.

Algumas críticas e considerações sobre a Teoria da Localização de Weber devem, no entanto, ser destacadas. Primeiramente, a respeito das forças aglomerativas que Weber tratou de maneira indistinta, Hoover ${ }^{48}$, citado por Ferreira (1989), mostra que elas combinam três elementos bastante distintos:

a) economias de escala - restritas às firmas individualmente, oriundas do aumento da escala de produção da firma num dado local;

b) economias de localização - para todas as firmas de uma mesma indústria em um único local, devido ao aumento da produção geral da indústria como um todo neste local (economias externas às firmas e internas à indústria);

48 HOOVER Jr., E. M. Location Theory and the shoe leather industries. Cambridge, Harvard University, 1937. 
c) economias de urbanização - influenciam todas as firmas em todas as indústrias em um dado local, em virtude de um aumento do nível econômico (população, renda, produto, etc.), para todas as indústrias tomadas em conjunto.

Dentre as três, as que mais interessam ao presente estudo são as economias de localização e de urbanização. A primeira, pelo fato de ser extremamente vantajoso para os abatedouros/frigoríficos de aves ou suínos localizarem-se perto das granjas produtoras de animais. A segunda corresponderia a um resumo das facilidades de infra-estrutura, em última instância representada pela malha viária que liga regiões de fronteira aos grandes centros de consumo ou escoamento do produto.

Uma outra importante consideração, destaca Ferreira (1989), reside no fato de Weber não considerar a interdependência locacional das firmas, pressupondo, além disso, regime de mercado de concorrência perfeita. Assim, estão implícitas as pressuposições de que o custo das informações seja nulo e que, dessa maneira, os agentes econômicos que atuam na sua teoria possuem perfeito conhecimento do mercado, o que implica em: "a) disponibilidade total de informações e b) que as decisões dos agentes econômicos são tomadas em uma situação na qual não há riscos nem incertezas" (id. ibid., p.94).

Segundo Azzoni (1982b), Weber recebeu ainda críticas de August Lösch, considerado como o mais importante teórico da economia espacial, pela consideração da minimização de custos para a definição do melhor sítio produtivo ao invés da maximização de lucros.

\section{August Lösch}

Se o nome von Thünen está associado aos seus famosos anéis, o de Weber aos triângulos locacionais, August Lösch $^{49}$ introduziu a figura dos hexágonos. Esse autor se tornou notável por sua teoria sobre sistemas de cidades (Azzoni, 1982b), balizando sua análise em raciocínios puramente econômicos (Ablas, 1982, Azzoni, 1982a e Ferreira 1989). O objetivo principal de seu trabalho foi o de desenvolvimento de uma teoria geral das localizações (Azzoni, 1982b), detalhando primeiramente os casos da agricultura e das indústrias, passando em seguida para a análise da formação das redes de cidades- considerada sua maior contribuição - cuja ênfase reside não mais na localização em si, mas na organização espacial do sistema econômico (Ablas, 1982).

Foi um dos primeiros teóricos ${ }^{50}$ a desenvolver com excelência a formação de áreas de mercado, aspecto fundamental para a determinação da localização ótima de

\footnotetext{
${ }^{49}$ LÖSCH, A. The economics of location. Trad. de H. H. Woglom e W. F. Stolper. Connecticut: Yale University Press, 1954.

${ }^{50}$ Azzoni (1982b) considera que o primeiro, porém de menor relevância que Lösch, a introduzir o enfoque de áreas de mercado foi Tord Palander em seu trabalho de 1935.
} 
uma firma, afastando-se dos enfoques puntiformes dos trabalhos anteriores de von Thünen e Weber que negligenciavam este tipo de consideração.

Sumariamente, as Figura 31a e 31b mostram a formação das áreas de mercado na teoria de Lösch. Na curva de demanda ${ }^{51}$ na Figura 31a, $p$ é o preço de venda de um determinado produto produzido por uma fazenda (ou então uma firma) no seu local de produção (semelhante a um preço FOB). Fica claro, portanto, que à medida que os custos de transportes são adicionados aos preços dos produtos no seu local de origem, a demanda diminui. No ponto $f$, o consumo será nulo. Dessa forma, $p f$ pode ser considerado como o frete máximo que o produtor poderá acrescer aos custos de produção $0 p$ para vender toda a sua produção. Mas, como o produtor pode vender o seu produto em todas as direções, pois o frete e as condições de transporte são as mesmas (Ablas, 1982), dá-se origem a uma área de mercado que circunscreve o produtor através da revolução da área escura com os eixos invertidos da Figura 31a, produzindo um cone de demanda (Figura 31b). Todavia, a definição final do tamanho das áreas de mercado de cada produtor (ou de cada firma), será feita a partir da comparação da curva de custos médios com a curva de demanda, determinando os seus volumes mínimos e máximos de venda.

Lösch demonstra posteriormente, de acordo com Ferreira (1989), que as diversas fazendas que se distribuem pela planície homogênea acabam por ter suas áreas de mercado circulares tangenciando umas às outras. Entretanto,

"a conformação circular das regiões não leva à exaustão total do território, razão pela qual não é uma solução estável. A estabilidade é conseguida com uma conformação hexagonal, à semelhança de uma colméia, que, a par de cobrir todo o território (como também o fariam quadrados e triângulos) é a forma mais próxima do círculo" (Azzoni, 1982b, p.22) (Figura 31c).

Além de ser a mais próxima do círculo, Lösch faz uma demonstração rigorosa, segundo Ferreira (1989), que a área de mercado hexagonal é a mais favorável.

Conforme Lösch caminha para a determinação das redes de cidades, acrescenta outros produtos com diferentes economias de escala e diferentes custos de transporte. Assim, conforme salienta Azzoni (1982b), em cima da rede inicial (Figura 31c) podem sobrepor-se outras redes hexagonais, com números distintos de centros, cada qual dando origem a áreas de mercado com extensões diversas da inicial. Como resultado, chega-se a uma complexa rede de centros, a qual seria a premissa teórica para a formação das redes de cidades.

\footnotetext{
${ }^{51}$ Ferreira (1989) esclarece que devido ao fato de Lösch admitir que o modelo de mercado vigente em sua teoria é o de concorrência monopolística (cujo principal fator de diferenciação dos produtos é a acessibilidade), a curva de demanda de mercado será também a da fazenda/firma.
} 


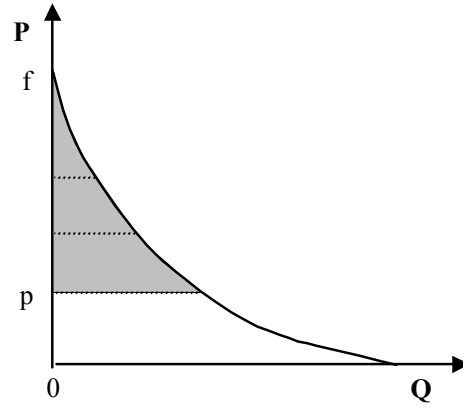

(a)

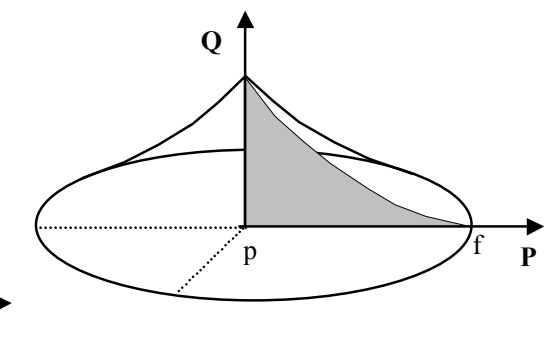

(b)

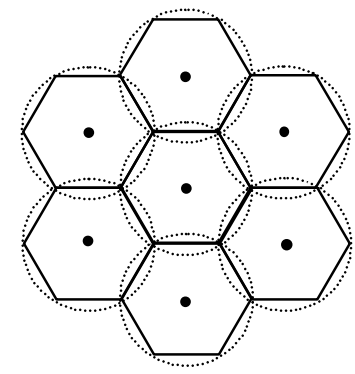

(c)

Figura 31- Curva de demanda espacial de mercado (a), cone de demanda (b) e áreas de mercado hexagonais (c) no modelo de Lösch (modificado de Ablas, 1982, p.144,145e148)

Sobre as principais considerações e críticas à obra de Lösch, pode-se destacar Azzoni (1982b) que admite que um dos principais pontos falhos da obra de Lösch seja a não consideração sistemática de variações espaciais de custo, dispensando maior cuidado para variações espaciais da demanda. Por sua vez, Ferreira (1989, p.182) comenta que o modelo de Lösch é

"uma idealização normativa mais de acordo com uma distribuição ótima e planejada das atividades econômicas em uma economia centralizada do que com as realidades das economias capitalistas de mercado, nas quais, fatores como a interdependência locacional, as economias de escala, de localização e urbanização e a constituição oligopólica das grandes empresas alteram o padrão de distribuição das atividades econômicas, com fortes tendências à concentração geográfica da atividade."

\section{Walter Isard}

A principal inquietação de Isard no desenvolvimento de sua primeira obra em 1956, foi incorporar o aspecto espacial à teoria econômica. Para tanto, haveria a necessidade de integrar as teorias da localização numa só doutrina geral, que seria absorvida pelos instrumentos das teorias neoclássicas de produção e preços já devidamente estabelecidas à época (Azzoni, 1982a).

Com este propósito, uma de suas principais metas foi "analisar o problema da localização de mínimo custo para a firma individual por meio do uso das técnicas neoclássicas da teoria da produção" (id. ibid, p.113). Para tanto, criou o conceito de insumo de transporte (movimento de uma unidade de peso ao longo de uma unidade de distância). O mais interessante deste artifício reside na busca de uma localização de mínimo custo através da análise de substituição de fatores. 
O raciocínio básico de sua obra foi interpretado por Azzoni (1982a, p.112-123) e será sucintamente descrito a seguir.

Partindo-se do triângulo locacional de Weber (Figura 27a) Isard propõe uma linha TJHS que é formada por pontos separados de $\mathrm{C}$ em iguais distâncias. Já o gráfico da Figura 32a apresenta esta mesma linha na forma de uma linha de transformação entre os insumos "distância de $M_{1}$ " $\left(d_{1}\right)$ e "distância de $M_{2}$ " $\left(d_{2}\right)$, sendo o conjunto de substituições técnicas eficientes, a uma dada distância de $\mathrm{C}$ (ou a um dado "nível de insumos de transporte" de C). Para se obter o equilíbrio, introduz elementos de custo por meio de linhas de preços. Se as tarifas de transporte e os pesos necessários das matérias-primas 1 e 2 forem semelhantes entre si, obtém-se o equilíbrio no ponto J. Com um suposto aumento no preço da tarifa do insumo 2, aumenta-se a força atrativa de $\mathrm{M}_{2}$, percebida através da maior inclinação da linha de preço (linha pontilhada na Figura $31 b)$, gerando um novo equilíbrio em $\mathrm{H}$.

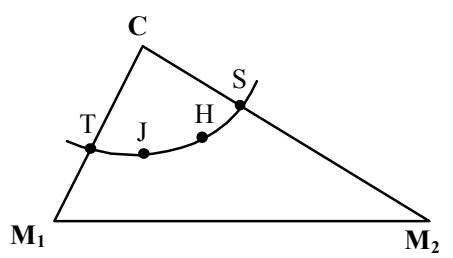

(a)

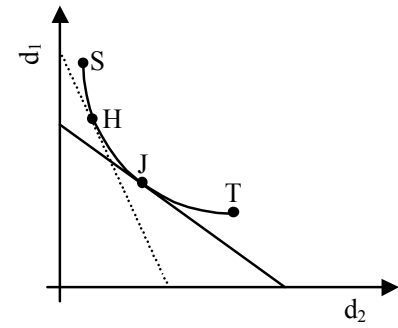

(b)

Figura 32- Triângulo locacional (a) Linha de transformação TJHS e isodespesas (b) (modificado de Azzoni, 1982a, p.114,115)

Porém o equilíbrio obtido não exaure as alternativas na busca do ponto de mínimo custo, pois foi feito fixando-se uma distância de $\mathrm{C}$ (ou a um dado "nível de insumo transporte"). Azzoni (1982a) explica que o ponto final de pleno equilíbrio seria alcançado com novas aplicações do arco à distância determinada no primeiro equilíbrio sobre cada fonte de matéria-prima, gerando uma segunda aproximação e assim sucessivamente. Para fechar o conceito de insumo transporte, Isard inclui a outra dimensão de sua natureza que são os pesos a serem transportados e não apenas a distância a percorrer, de modo que as linhas de transformação podem ser deslocadas tanto por alterações de distâncias como de preços, e as linhas de preço, modificadas somente por alterações nas tarifas de transporte.

A obra de Isard é muito mais completa do que exposto aqui, inserindo inclusive outros fatores de localização como custos do trabalho e energia. Porém, para as pretensões deste trabalho, desfecha-se por aqui.

Apesar de ser um comentário do início da década de 80, Azzoni (1982b, p.24) afirma não ser muito extremo dizer 
"que a última grande contribuição à teoria da localização clássica deve-se a Walter Isard. Após sua obra, pouco ficou a ser empreendido nessa linha de análise, a não ser refinamentos, aplicações e aprofundamentos de aspectos tratados ou sugeridos por esse autor".

A Walter Isard atribui-se, ainda, o papel de um dos pioneiros da chamada "Ciência Regional", campo multidisciplinar que vem atraindo geógrafos, economistas, administradores de empresas, entre outros, para estudos teóricos e empíricos. 